$$
\begin{gathered}
\text { UNIVERSIDADE DE SÃO PAULO } \\
\text { INSTITUTO DE ARQUITETURA E URBANISMO } \\
\text { PROGRAMA DE PÓS-GRADUAÇÃO EM ARQUITETURA E URBANISMO }
\end{gathered}
$$

Fabrício Ribeiro dos Santos Godoi

\title{
Territórios universitários: o Campus em Pirassununga
}

São Carlos 


$$
\text { . }
$$




\author{
UNIVERSIDADE DE SÃO PAULO \\ INSTITUTO DE ARQUITETURA E URBANISMO \\ PROGRAMA DE PÓS-GRADUAÇÃO EM ARQUITETURA E URBANISMO
}

Fabrício Ribeiro dos Santos Godoi

Territórios universitários: o Campus em Pirassununga

Versão corrigida.

Dissertação apresentada ao Programa de PósGraduação em Arquitetura e Urbanismo do Instituto de Arquitetura e Urbanismo da Universidade de São Paulo, para obtenção do título de Mestre em Arquitetura e Urbanismo.

Orientador: Carlos Roberto Monteiro de Andrade

São Carlos

Maio de 2017 
AUTORIZO A REPRODUÇÃO TOTAL OU PARCIAL DESTE TRABALHO, POR QUALQUER MEIO CONVENCIONAL OU ELETRÔNICO, PARA FINS DE ESTUDO E PESQUISA, DESDE QUE CITADA A FONTE.

Ficha catalográfica elaborada pela Biblioteca do Instituto de Arquitetura e Urbanismo com os dados fornecidos pelo(a) autor(a)

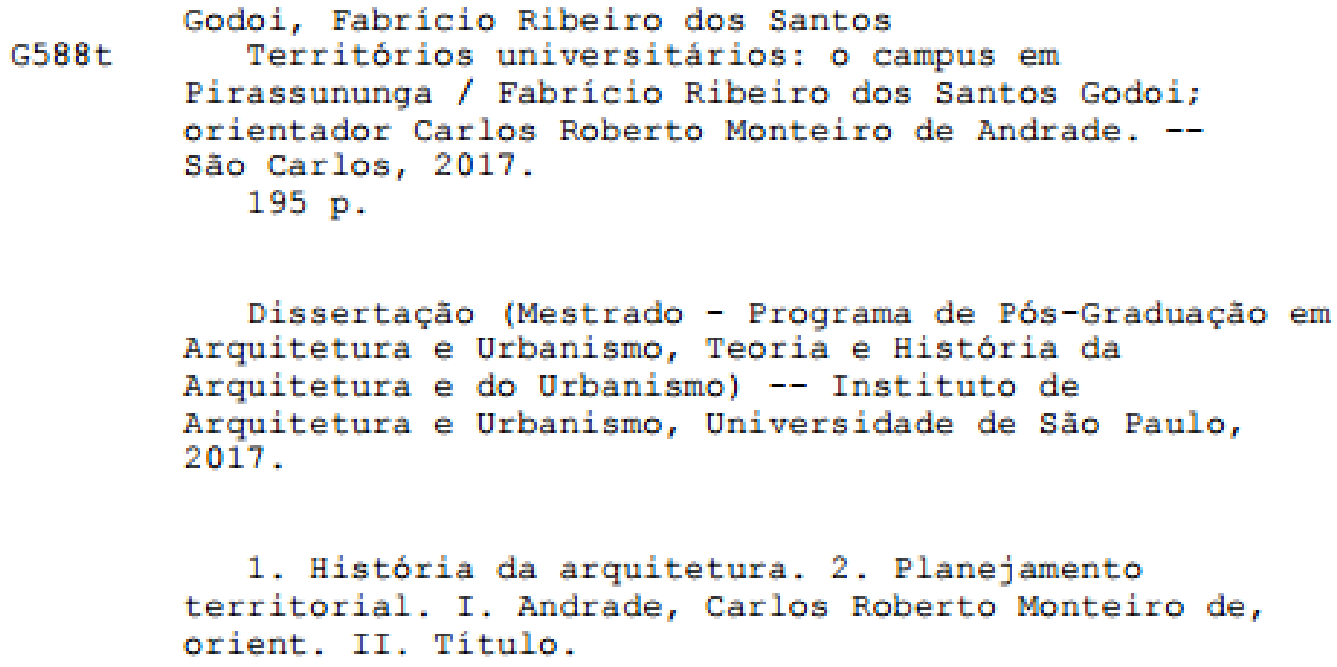




\section{FOLHA DE JULGAMENTO}

\section{Candidato(a): Fabrício Ribeiro dos Santos Godoi}

Título da dissertação: "Territórios universitários: o campus em Pirassununga"

Data da defesa: 05/05/2017

Orientador: Prof. Dr. Carlos Roberto Monteiro de Andrade

\section{Comissão Julgadora:}

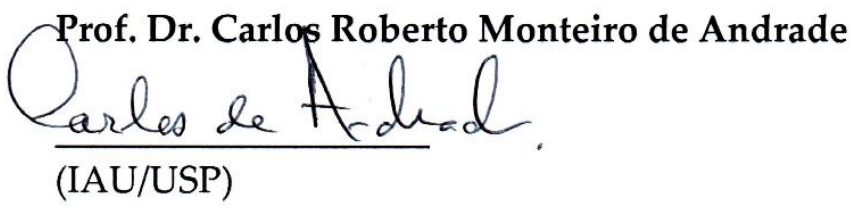

Profa. Dra. Luciana Bongiovanni Martins Schenk (IAU/USP)

Prof. Dr. Ricardo Siloto da Silva (DECiv/ UFSCar)

Prof. Dr. Luiz Augusto Fernandes Rodrigues (IACS/UFF)

\section{Resultado:}
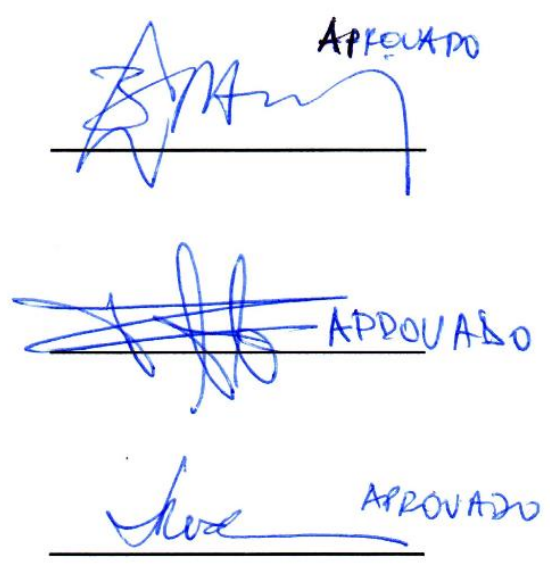

Coordenadora e Presidente da Comissão de Pós-Graduação do Programa de PósGraduação em Arquitetura e Urbanismo: Profa. Dra. Cibele Saliba Rizek. 
$$
\text { . }
$$ 
À Poliana e ao Artur. 



\section{AGRADECIMENTOS}

Agradeço em primeiro lugar ao professor Carlos Roberto Monteiro de Andrade pela orientação, pela inspiração e pela oportunidade. Agradeço à professora Sarah Feldman pela acolhida e atenção; à professora Luciana Schenk pelo apoio, acompanhamento e inspiração; ao professor Francisco Sales Trajano Filho pelos comentários no Seminário de Acompanhamento e ao professor Ricardo Siloto pelos comentários na banca de qualificação. Agradeço aos professores David Sperling, Fábio Lopes, Márcio Fabrício e Cibele Rizek pelas excelentes aulas nas disciplinas de pós-graduação; ao professor Euler Sandeville pelas informações antes de iniciar esse trabalho; ao professor Ricardo Albuquerque pelas informações sobre o campus e sobre Fernando Costa; ao professor Miguel Buzzar, pelos contatos na Secretaria de Agricultura e acesso a arquivos.

Agradeço ao IAU-USP, por permitir a realização desta pesquisa concomitante ao exercício profissional. Agradeço aos colegas contemporâneos do IAU-USP, aos colegas do movimento estudantil da pós-graduação, aos colegas dos demais programas de pós-graduação da USP e da UFSCAR e aos colegas do grupo de pesquisa Urbis, cada qual com sua importância para a formação que me permitiu elaborar este trabalho.

Agradeço aos colegas da SEF, em especial Wellington Kanno, Thiago Silva e Soraya Raspantini, pela compreensão nas ausências e apoio. Agradeço aos colegas da Prefeitura do Campus de Pirassununga e da Faculdade de Zootecnia e Engenharia de Alimentos, que colaboraram com muitas informações. Agradeço aos dirigentes da SEF, pela autorização para realizar esta pesquisa concomitante ao exercício profissional.

Agradeço à minha família pela base intelectual, pelo apoio e pela compreensão nas ausências. Agradeço à Poliana, pelo apoio, pelo compartilhamento de suas experiências e principalmente pela compreensão. 



\title{
RESUMO
}

GODOI, F. R. S. Territórios universitários: o campus em Pirassununga. 2017. 198 f. Dissertação (mestrado em Arquitetura e Urbanismo) - Instituto de Arquitetura e Urbanismo, Universidade de São Paulo, São Carlos, 2017.

O tema desta dissertação é o território ocupado pelas universidades, com um recorte mais preciso: aqueles situados no meio rural e, mais especificamente, o caso do Campus Fernando Costa da Universidade de São Paulo, em Pirassununga/SP. Os objetivos são: estudar os problemas de planejamento desses territórios, tendo como foco os espaços em ambiente rural; estudar o percurso histórico-institucional desses territórios; e estudar suas relações com a cidade. O texto se inicia com uma revisão bibliográfica e uma contextualização da história das universidades. Apresentamos o percurso histórico do território, seu planejamento inicial, as transformações ao longo do tempo e a situação atual. Realizamos análises físico-territoriais e documentais complementares à análise histórica, incluindo estudos comparativos com outros territórios universitários situados no meio rural. Concluímos com a apresentação de algumas dificuldades e perspectivas, direcionadas ao caso específico e alguns elementos que possam ser generalizados.

Palavras chave: Universidade; territórios universitários; Universidade de São Paulo; Pirassununga.

\begin{abstract}
GODOI, F. R. S. University territories: the campus in Pirassununga. 2017. $198 \mathrm{f}$. Dissertação (mestrado em Arquitetura e Urbanismo) - Instituto de Arquitetura e Urbanismo, Universidade de São Paulo, São Carlos, 2017.

The main theme of this study is the territory occupied by the universities, with a cutout more precise: those situated in rural areas and, more specifically, the case of the Campus Fernando Costa, University of São Paulo, in Pirassununga/SP. The objectives are: studying the problems of planning in those areas, with a focus in the rural environment; studying the history and institutional these territories; and to study their relations with the city. The text begins with a literature review and a contextualization of the history of universities. We present the history of the territory, the initial planning, the changes over time and the current situation. We dissolved territorial and additional documentary evidence to historical analysis, including comparative studies with other Brazilian universities territories located in rural areas. We conclude presenting some problems and prospects, directed to specific case and some elements that may be generalized.
\end{abstract}

Key words: university; university territories; University of São Paulo; Pirassununga. 



\section{LISTA DE FIGURAS}

1 Escola Prática de Agricultura em $1950 \quad 6$

2 Universidade de Chicago (Campus Master Plan) 18

3 Illinois Institute of Technology 19

4 Projeto de moradia estudantil de Alvar Aalto para o MIT 21

5 Universidade de Nova lorque em Albany 22

6 Modelo digital do módulo da Universidade de Nova lorque em Albany 22

7 Universidade da California em Santa Cruz 23

8 Universidade de East Anglia 25

9 Universidade de Bochum 26

10 Universidade de Paris - Tolbiac 27

11 Universidade de Oregon (diagnóstico de 2014) 29

12 Reforma da sala do Grupo Alexander em São Carlos 30

13 Brasão da Universidade Nacional Mayor de San Marcos 38

14 Fundações de edifício planejado para a Cidade Universitária de Buenos Aires

15 Universidade Nacional Autônoma do México 43

16 Universidade de Concepción, praça central 45

17 O primeiro prédio da Faculdade de Direito de São Paulo 50

18 O segundo prédio da Faculdade de Direito de São Paulo 50

19 O terceiro prédio da Faculdade de Direito de São Paulo 50

20 Proposta de Le Corbusier para a Cidade Universitária do Rio de Janeiro 53

21 Proposta aprovada, de Jorge Moreira, para a Cidade Universitária do Rio de Janeiro 53

22 Os primeiros projetos para a Cidade Universitária de São Paulo 56

23 Trinity College (1872) 59 
24 Bryn Mawr (1892)

25 Mapa de 1910, posterior ao plano de Olmsted para o Massachusetts Agricultural College

26 lowa Agricultural College

27 Universidade de Auburn 62

28 Cornell University 62

29 Universidade de Illinois em Urbana / Champaign 63

30 McGill University 63

31 Universidade de Alberta 64

32 Butte College 64

33 Escuela Normal Agricola 65

34 Ruínas do Imperial Instituto Bahiano de Agronomia 66

35 Campus Capão do Leão da UFPel 66

36 O parque da ESALQ em construção, em $1907 \quad 68$

37 Universidade Rural de Minas Gerais, atual UFV, na década de $1920 \quad 69$

38 Busto de Fernando Costa no prédio central da USP em Pirassununga 79

39 Condições atuais do acervo do NE/SAA

82

40 Carimbo de projeto realizado pela DOP, modificando o ginásio de esportes da Escola Prática de Agricultura de Pirassununga

41 Projeto anterior à construção da Escola Prática de Agricultura, assinado pela antiga Divisão de Engenharia Rural, atual NE/SAA

42 Exemplos de carimbos de projetos efetivamente construídos (todos com registros da Sociedade Construtora Brasileira)

43 Recorte de publicação que menciona a obra da Escola Prática de Agricultura em Pirassununga

44 Imagem orbital com demarcação aproximada da propriedade do Major Rolla 
46 Prédios dispostos de maneira parqueada, sem cercamentos, na EPA 93

47 A rotatória no cume do eixo principal e o prédio central da EPA 94

48 As vias curvilíneas que desdobram visuais na EPA 94

49 A EPA, em meados dos anos 50, com vegetação ainda modesta 95

50 Mapa de usos originais da EPA 98

51 Mapa de Pirassununga, provavelmente dos anos $1930 \quad 99$

52 A praça central de Pirassununga em $1955 \quad 100$

53 O projeto Morimont, setorizando o território da futura ESALQ 101

54 O projeto do parque da ESALQ 102

55 O parque da ESALQ, projetado por Puttmans 104

56 O edifício principal da UFRRJ 106

$\begin{array}{lll}57 & \text { Implantação da UFRRJ } & 108\end{array}$

58 Estátua de Fernando Costa na portaria da UFRRJ 109

59 Centro de Ciências Agrárias da UFPB 111

60 Situação do Centro de Ciências Agrárias da UFPB 112

61 Universidade Federal Rural da Amazônia 114

62 Implantação da UFRA 116

63 EPA nos anos 1950, em processo de deterioração física 118

64 Indicação da área ocupada pela Rodovia Anhanguera 122

65 Imagem orbital do recorte anterior 122

66 Visita de Jânio Quadros ao IZIP 124

67 O clube de campo nos anos $1950 \quad 128$

68 O antigo parque de exposições 128

69 Alas residenciais antes das reformas 129

70 Imagem aérea de Pirassununga em 1955

71 Edifício João Soares Veiga 130 
72 Fundações de casas da antiga colônia Francischini

73 Estações de tratamento de água

74 O antigo campus Maria Cândida da Uniban, atual campus Vila Guilherme da Unianhanguera 135

75 Uma casa ocupada como depósito 139

76 Vista do eixo principal próximo à Rodovia Anhanguera 147

77 O portal demolido 147

78 Mapa indicando os edifícios novos na área do Parque de Exposições 151

79 Mapa indicando os edifícios novos na área do Prédio Central 151

80 Estado atual da arquibancada 152

81 Área esportiva 153

82 Mapa indicando os edifícios novos na área da Estrada do Povo 153

83 Portarias nova e antiga, antes da obra inacabada do restauro 154

84 Obra de restauro do portal antigo 154

85 Situação da USP e da zona norte 157

86 Avenida Duque de Caxias Norte antes da duplicação 158

87 Avenida Duque de Caxias Norte antes da duplicação 158

88 A queda do muro da fachada principal da USP 163

89 Avenida Duque de Caxias Norte e acesso ao campus, 2011

90 Avenida Duque de Caxias Norte e acesso ao campus, 2004

91 A área da USP em Pirassununga e a cidade, 2016

\section{LISTA DE QUADROS}

1 Expansão da USP

2 Verbas destinadas às obras em execução, 2014 


\section{LISTA DE SIGLAS}

$13^{\circ} \mathrm{RCM} \quad 13^{\circ}$ Regimento de Cavalaria Mecanizada - Exército Brasileiro

2ำ RDC 2ำ Regimento de Cavalaria Divisionária - Exército Brasileiro

APLACE Academia Pirassununguense de Letras, Artes e Ciências

APP Área de Preservação Permanente

BDNA Bloco Didático de Nutrição Animal - FZEA/USP

BID Banco Interamericano de Desenvolvimento

CAEPE Centro de Apoio ao Ensino, Pesquisa e Extensão - FMVZ/USP

CCA Centro de Ciências Agrárias - UFPB

CDHU Companhia de Desenvolvimento Habitacional e Urbano

CEFET Centro Federal de Educação Tecnológica

CEPTA Centro Nacional de Pesquisa e Conservação de Peixes Continentais

CEPTOX Centro de Pesquisas em Toxicologia Veterinária

CIZIP Centro Intraunidade de Zootecnia e Indústrias Pecuárias "Fernando Costa"

CNEPA Centro Nacional de Ensino e Pesquisa Agropecuária

Condephaat Conselho de Defesa do Patrimônio Histórico Artístico Arqueológico e Turístico

CPC Centro de Preservação Cultural - USP

CPOS Companhia Paulista de Obras e Serviços

CREA-SP Conselho Regional de Engenharia e Agronomia, Departamento de São Paulo

COESF Coordenadoria do Espaço Físico - USP

CUASO Cidade Universitária Armando de Salles Oliveira

DOP Departamento de Obras Públicas

DVATCOM Divisão de Atendimento à Comunidade - PUSP-FC/USP

EACH Escola de Artes, Ciências e Humanidades - USP

EERP Escola de Enfermagem de Ribeirão Preto - USP

EESC Escola de Engenharia de São Carlos - USP

ESALQ Escola Superior de Agricultura Luiz de Queiroz - USP

ESAV Escola Superior de Agricultura e Veterinária

ETEC Escola Técnica Estadual

FAU Faculdade de Arquitetura e Urbanismo - USP

FCAP Faculdade de Ciências Agrárias do Pará

FCFRP Faculdade de Ciências Farmacêuticas de Ribeirão Preto - USP

FEA Faculdade de Economia, Administração e Ciências Contábeis - USP

FEARP Faculdade de Economia e Administração de Ribeirão Preto - USP 


\begin{tabular}{|c|c|}
\hline FFCL & Faculdade de Filosofia, Ciências e Letras - USP \\
\hline FFLCH & Faculdade de Filosofia, Letras e Ciências Humanas - USP \\
\hline FFCLRP & Faculdade de Filosofia, Ciências e Letras de Ribeirão Preto - USP \\
\hline FMRP & Faculdade de Medicina de Ribeirão Preto - USP \\
\hline FMSP & Faculdade de Medicina de São Paulo - USP \\
\hline FMV & Faculdade de Medicina Veterinária - USP \\
\hline FMVZ & Faculdade de Medicina Veterinária e Zootecnia - USP \\
\hline FOB & Faculdade de Odontologia de Bauru - USP \\
\hline FORP & Faculdade de Odontologia de Ribeirão Preto - USP \\
\hline FUVEST & Fundação Universitária para o Vestibular \\
\hline FZEA & Faculdade de Zootecnia e Engenharia de Alimentos - USP \\
\hline HRAC & Hospital de Reabilitação de Anomalias Crânio-Faciais \\
\hline IBAPE & Instituto de Avaliações e Perícias de Engenharia \\
\hline IBGE & Instituto Brasileiro de Geografia e Estatística \\
\hline ICMBio & Instituto Chico Mendes de Conservação da Biodiversidade \\
\hline ICMS & Imposto sobre Circulação de Mercadorias e Serviços \\
\hline IE & Instituto de Engenharia \\
\hline IIT & Illinois Institute of Technology \\
\hline INCRA & Instituto Nacional de Colonização e Reforma Agrária \\
\hline IZIP & Instituto de Zootecnia e Indústrias Pecuárias "Fernando Costa" \\
\hline LDB & Lei de Diretrizes e Bases \\
\hline MIT & Massachusetts Institute of Technology \\
\hline MMA & Ministério do Meio Ambiente \\
\hline MAA (MAPA) & Ministério da Agricultura, Pecuária e Abastecimento \\
\hline NE/SAA & Núcleo de Engenharia da SAAESP \\
\hline NYU & New York University \\
\hline PCB & Partido Comunista Brasileiro \\
\hline PDC & Partido Democrata Cristão \\
\hline PRP & Partido Republicano Paulista \\
\hline PSD & Partido Social Democrático \\
\hline PUCRJ & Pontifícia Universidade Católica do Rio de Janeiro \\
\hline PUSP-FC & Prefeitura do Campus USP "Fernando Costa" \\
\hline PTB & Partido Trabalhista Brasileiro \\
\hline REUNI & Reestruturação e Expansão das Universidades Federais \\
\hline SAAESP & Secretaria de Agricultura e Abastecimento do Estado de São Paulo \\
\hline
\end{tabular}




\begin{tabular}{|c|c|}
\hline SEF & Superintendência do Espaço Físico - USP \\
\hline SVOP & Secretaria de Viação e Obras Públicas do Estado de São Paulo \\
\hline TFG & Trabalho Final de Graduação \\
\hline $\mathrm{UDCH}$ & Unidade Didático Clínico Hospitalar - FZEA/USP \\
\hline UDN & União Democrática Nacional \\
\hline UNAM & Universidad Nacional Autónoma de México \\
\hline Unian & Universidade Anhanguera \\
\hline Uniban & Universidade Bandeirante de São Paulo \\
\hline Unicamp & Universidade Estadual de Campinas \\
\hline UFAM & Universidade Federal da Amazônia \\
\hline UFBA & Universidade Federal da Bahia \\
\hline UFPB & Universidade Federal da Paraíba \\
\hline UFPel & Universidade Federal de Pelotas \\
\hline UFPR & Universidade Federal do Paraná \\
\hline UFRA & Universidade Federal Rural da Amazônia \\
\hline UFRB & Universidade Federal do Recôncavo Baiano \\
\hline UFRGS & Universidade Federal do Rio Grande do Sul \\
\hline UFRJ & Universidade Federal do Rio de Janeiro \\
\hline UFRRJ & Universidade Federal Rural do Rio de Janeiro \\
\hline UFSCar & Universidade Federal de São Carlos \\
\hline UFV & Universidade Federal de Viçosa \\
\hline USP & Universidade de São Paulo \\
\hline VCA & Departamento de Criação de Ruminantes e Alimentação - FMVZ/USP \\
\hline VNP & Departamento de Nutrição e Produção Animal - FMVZ/USP \\
\hline VPA & Departamento de Produção Animal - FMVZ/USP \\
\hline VPT & Departamento de Patologia - FMVZ/USP \\
\hline
\end{tabular}





\section{SUMÁRIO}

\begin{tabular}{|c|c|}
\hline Introdução & 1 \\
\hline $\begin{array}{l}\text { Capítulo } 1 \\
\text { Territórios universitários }\end{array}$ & 13 \\
\hline 1.1 Questões de planejamento dos territórios universitários & 13 \\
\hline 1.1.1 Historiografia do tema & 13 \\
\hline $\begin{array}{l}\text { 1.1.2 Considerações sobre planejamento físico-territorial das } \\
\text { universidades }\end{array}$ & 17 \\
\hline 1.1.3 Campus, cidade universitária e territórios universitários & 32 \\
\hline 1.2 A universidade brasileira & 38 \\
\hline $\begin{array}{l}\text { 1.2.1 Colônia e independência: América Latina e a experiência } \\
\text { brasileira }\end{array}$ & 38 \\
\hline 1.2.2 A educação superior no Brasil & 46 \\
\hline 1.3 Os territórios universitários no meio rural & 57 \\
\hline 1.3.1 Ensino superior no campo & 58 \\
\hline 1.3.2 Ensino superior no campo no Brasil & 65 \\
\hline $\begin{array}{l}\text { Capítulo } 2 \\
\text { Modernidade no campo: uma escola para transformar o interior }\end{array}$ & 73 \\
\hline 2.1 Fernando Costa e o projeto de modernização do campo brasileiro & 73 \\
\hline 2.2 O projeto da Escola Prática de Agricultura em Pirassununga & 81 \\
\hline 2.2.1 As condições ambientais & 89 \\
\hline 2.2.2 As condições e decisões projetuais & 91 \\
\hline 2.2.3 As condições pedagógicas & 96 \\
\hline 2.3 A relação entre Pirassununga e a Escola Agrícola & 98 \\
\hline 2.4 Estudos comparados & 101 \\
\hline 2.4.1 Piracicaba & 101 \\
\hline 2.4.2 Seropédica & 105 \\
\hline 2.4.3 Areia & 110 \\
\hline 2.4.4 Belém & 114 \\
\hline
\end{tabular}




\begin{tabular}{l|l}
\hline $\begin{array}{l}\text { Capítulo } 3 \\
\text { Progresso, crise e a chegada gradual da Universidade }\end{array}$ & 117 \\
\hline $\begin{array}{c}\text { 3.1 O ocaso do ensino agrícola e o projeto de industrialização do } \\
\text { campo }\end{array}$ & 118 \\
\hline $\begin{array}{c}\text { 3.1.1 A primeira transformação da paisagem: construção da Via } \\
\text { Anhanguera }\end{array}$ & 120 \\
\hline 3.2 Escola técnica e a sociedade dos anos 50 a 70 & 123 \\
\hline 3.2.1 A relação entre Pirassununga e a escola técnica (IZIP/CIZIP) & 127 \\
\hline 3.2.2 A influência das decisões administrativas no espaço físico & 132 \\
\hline 3.3 A chegada da USP em Pirassununga & 138 \\
\hline $\begin{array}{c}\text { 3.3.1 O crescimento da USP em Pirassununga em comparação } \\
\text { com os demais campi da Universidade }\end{array}$ & 140 \\
\hline $\begin{array}{c}\text { 3.3.2 A segunda transformação da paisagem: duplicação da Via } \\
\text { Anhanguera }\end{array}$ & 146 \\
\hline 3.4 O Campus Fernando Costa e a USP hoje & 149 \\
\hline $\begin{array}{c}\text { 3.4.1 A terceira transformação da paisagem: duplicação da } \\
\text { Avenida Duque de Caxias Norte }\end{array}$ & 157 \\
\hline $\begin{array}{l}\text { 3.5 Dificuldades: a expansão do espaço físico e sua relação com a } \\
\text { universidade operacional }\end{array}$ & 167 \\
\hline $\begin{array}{l}\text { Capítulo 4 } \\
\text { Conclusão: perspectivas }\end{array}$ & 178 \\
\hline $\begin{array}{c}\text { 4.1 Perspectivas: a relação do Campus Fernando Costa e } \\
\text { Pirassununga hoje }\end{array}$ & 178 \\
\hline $\begin{array}{c}\text { 4.1.1 Algumas diretrizes de planejamento para o Campus } \\
\text { Fernando Costa da USP }\end{array}$ & 180 \\
\hline $\begin{array}{c}\text { 4.1.2 Especificidades e generalidades do caso estudado } \\
\text { Referências bibliográficas }\end{array}$ & 182 \\
\hline Anexos & 187 \\
\hline
\end{tabular}






\title{
INTRODUÇÃO
}

\begin{abstract}
"A vida mudou muito, nas últimas décadas. Não adianta discutir a universidade só internamente, ou só articulada com o mercado, como tanto se vê. Pretendo levar a sério a ideia de que as mudanças continuarão sendo, pelo menos por algum tempo, um fator decisivo em nossa experiência de vida. Disso, o que decorre para o ensino universitário, para a pesquisa, para a ligação que o campus mantém com a sociedade?" ${ }^{1}$
\end{abstract}

O estudo dos lugares onde a instituição universitária se situa é objeto de pesquisas desde a virada do século XIX para o século XX. Alguns autores, como Gaines (1991) e Muthesius (2000) classificam os espaços universitários como categorias únicas de ocupação do território, cuja análise deve se fundamentar por princípios artísticos (Gaines) ou por sua inovação no sentido da utopia (Muthesius) ${ }^{2}$. Essa instituição ocupa um espaço físico, um lugar, que - pelo menos em tese - deve ter as características adequadas para motivar e favorecer o pensamento. Hoje se tratam de espaços complexos, já que para realizar pesquisas em todos os campos do conhecimento são precisos lugares com muitas especificidades, variando desde laboratórios bastante complexos, bibliotecas multi midiáticas, espaços para apresentações experimentais, entre tantas outras atividades - inclusive as mais corriqueiras. É, portanto, um lugar que difere sensivelmente dos demais lugares de concentração de pessoas, sejam as cidades, suas partes ou áreas não urbanizadas. Entendemos essa condição como um fato, inerente à própria multiplicidade da sociedade humana, ainda que variável ao longo do tempo. Cabe-nos estudar esses recortes do território, sua relação com a cidade e sua relação com a estrutura da instituição - ultrapassando o estudo exclusivamente do lugar.

Neste trabalho será estudada essa categoria: os territórios universitários. Um tema transdisciplinar, que poderia ser estudado sob a ótica da antropologia, da sociologia, da geografia, etc. A abordagem se mantém no campo da história da arquitetura e urbanismo, dentro do qual procuramos suprir lacunas. A partir do estudo

\footnotetext{
${ }^{1}$ RIBEIRO (2014), pg. 16.

2 Para MUTHESIUS (2000), utopia tem um sentido não apenas de algo inatingível, mas como objetivo da ação prática dos envolvidos na produção do objeto (o espaço da instituição universitária e a universidade em si).
} 
de um caso específico - o Campus Fernando Costa da Universidade de São Paulo (USP), na cidade de Pirassununga/SP - serão apresentados temas que giram ao redor dos territórios universitários em espaços caracterizados como rurais ou ainda com vínculos com esse ambiente. Essa extrapolação é intencional: não desejamos realizar um estudo endógeno, ainda que os recortes espaciais e temáticos indiquem isso.

A justificativa da escolha do tema, além da escassez de estudos sobre territórios universitários, recai sobre a atividade acadêmica e profissional do autor. Desde a graduação, cujo tema do Trabalho Final foi um campus universitário, até a prática profissional, pois é arquiteto e urbanista da Universidade de São Paulo há sete anos, onde seu local de trabalho e objeto de intervenção profissional é também o objeto empírico desta pesquisa, onde se responsabiliza por atividades de planejamento do espaço físico e projetos de arquitetura no Campus Fernando Costa. No cotidiano profissional se observam as diferenças entre as territorialidades de diferentes campi da USP, especialmente entre os campi do interior e o da capital. Essas diferenças também são visíveis quando se visitam outros territórios universitários, de instituições diversas.

O texto se estrutura em quatro capítulos. O primeiro reúne a revisão bibliográfica, abordando as questões históricas dos territórios universitários e as definições dos autores principais. O segundo capítulo apresenta as condições que ensejaram a criação da Escola Prática de Agricultura, que deu origem ao Campus Fernando Costa. O terceiro capítulo conta a história deste Campus, abordando questões diversas que influenciam nas transformações desta categoria de territórios. E o quarto capítulo, à guisa de conclusão, apresenta algumas dificuldades e perspectivas.

Os objetivos do trabalho são: estudar os problemas de planejamento desses territórios, tendo como foco os espaços em ambiente rural; estudar o percurso histórico-institucional desses territórios; e estudar suas relações com a cidade. Algumas das perguntas que desejamos responder são: quais as principais intervenções, que causaram alterações significativas na paisagem? Qual a relação entre o lugar e a instituição? Quais as relações do lugar com os projetos pedagógicos e a administração universitária? Quais as relações do lugar com os interesses operacionais da universidade contemporânea? 
No primeiro capítulo, "Territórios universitários", serão tratados os temas que concernem ao período anterior da fundação da Escola Prática de Agricultura em Pirassununga. Trata-se de um capítulo histórico, que procura revisar a bibliografia existente e preparar uma contextualização temática, antes de abordar as questões específicas do estudo de caso.

A primeira seção é denominada "Questões de planejamento dos territórios universitários", onde será apresentado um relato das experiências de planejamento de territórios universitários e alguns casos no Brasil. Esse relato extrapola o período de fundação da Escola Prática de Agricultura. Consideramos que esse conhecimento é necessário para a contextualização não apenas dos antecedentes da fundação da Escola Prática de Agricultura, mas também para a continuidade da sua história. Já há algumas décadas entendemos o planejamento não apenas como uma prática ocasional, mas como um processo ou um fluxo de trabalho contínuo. Mas essa transformação na prática de planejamento não foi a primeira, nem é exclusiva das macro escalas. O planejamento dos territórios universitários também se modificou ao longo do tempo.

A seção seguinte recebeu o título " $A$ universidade brasileira". Apresentaremos um brevíssimo histórico das universidades latino-americanas, importantes desde a chegada dos europeus nesse continente e explicações para a relativa defasagem brasileira. Para sua redação, consultamos fontes primárias, como os sítios das universidades na rede mundial de computadores ou textos históricos. A seguir, serão apresentadas as fases preliminares da fundação das universidades no Brasil, desde o período da educação jesuítica, as primeiras escolas isoladas e as tentativas frustradas de formação de universidades no período anterior ao governo Getúlio Vargas. A contextualização histórica que permite o surgimento das universidades e a ascensão de personalidades que acreditavam no poder transformador da educação são importantes não apenas para compreender a fundação das primeiras universidades, mas também as escolas técnicas e práticas. A redação desse histórico foi complementada com algumas visitas a campo, em universidades chilenas (Universidad de Concepción, Universidad Catolica de Chile, Universidad de Chile, Universidad de Talca, Pontifícia Universidad Catolica de Valparaiso), argentinas (Universidad de Buenos Aires), uruguaias (Universidad de la Republica) e mexicanas (Universidad Autonoma Nacional de Mexico). 
O texto também apresentará as condições efetivas que permitiram a fundação das duas instituições que esta dissertação enfoca: a Universidade de São Paulo e a Escola Prática de Agricultura. O ambiente intelectual no Estado era reflexo da economia pujante, de um movimento cultural e artístico em constante renovação e um processo de aglutinação em torno de ideais desenvolvimentistas. Politicamente a situação era complexa, pois, após décadas de poder, a elite paulista sofreu um imenso revés com a tomada de poder de Getúlio Vargas que, no entanto, permitiu a ascensão de algumas das personalidades que ensejaram a fundação dessas instituições.

A seção seguinte é um panorama que procurará aproximar os espaços de caráter rural com a historiografia geral do tema, denominada "Os territórios universitários no meio rural", recortando o tema "territórios universitários". O conhecimento desse histórico permite contextualizarmos a fundação da Escola Prática de Agricultura no seu tempo, identificando as iniciativas já existentes e suas relações gerais com a educação superior. Ainda que a Escola Prática de Agricultura tenha sido fundada como escola de nível ginasial ou técnico, admite-se a comparação em função da sua complexidade funcional e a futura conversão em estabelecimento de ensino superior. Também apresentamos um brevíssimo histórico da educação superior no campo.

A questão da nomenclatura será tratada no título seguinte. Afinal, como nos referirmos a este tipo de território: campus ou cidade universitária? O primeiro se vincula à tradição norte-americana. $O$ segundo, historicamente, referia-se às cidades que abrigavam universidades e se confundiam com elas, desde o período medieval. No Brasil há uma interpretação diferente, referindo-se aos casos que o espaço da Universidade abrigaria todas (ou quase todas) as funções necessárias para sua existência, conformando-se quase como uma cidade à parte da cidade que a sedia. As limitações de cada termo e a necessidade de uma definição mais ampla explica a adoção de "território universitários". Território por definição já é um termo mais amplo. Milton Santos define o lugar como o território palpável onde as ações globalizantes se territorializam ${ }^{3}$.

A função deste capítulo, portanto, é preparar o leitor com os antecedentes da história da Universidade de São Paulo em Pirassununga. As questões específicas

${ }^{3}$ SANTOS (1994). 
interligadas com essa história serão apresentadas nos capítulos seguintes, conjuntamente com os fatos e relatos mais importantes. Por isso não pretendemos esgotar os assuntos: são introduções que constam de textos aqui mencionados ou que merecem novos estudos, mais aprofundados e detalhados.

No segundo capítulo, denominado "Modernidade no campo: Uma escola para transformar o interior", o assunto é a fundação da Escola Prática de Agricultura em Pirassununga (figura 1). Diferentemente da abordagem do capítulo anterior, que é essencialmente histórico, neste capítulo também realizamos uma abordagem analítica do território, tanto a partir da análise de documentos, como análises visuais e comparações com outros territórios universitários (como a Escola Superior de Agricultura Luiz de Queiroz - ESALQ; a Universidade Federal Rural do Rio de Janeiro - UFRRJ; a Universidade Federal da Paraíba, campus Areia - UFPB e a Universidade Rural da Amazônia - UFRA).

Abrimos o capítulo com uma análise do trabalho realizado nas gestões de Fernando Costa em diferentes instituições, político vigoroso, com carreira continuamente ascendente e abruptamente interrompida, cujas ideias principais são essenciais para entender o projeto de modernização do campo, como parte de um projeto de modernização nacional. Também realizamos uma tentativa de verificar algum vínculo entre a sua presença pessoal e a arquitetura adotada. Pode-se discutir, inclusive, a possibilidade de adoção de um "estilo". Na tese de Luciana Mascaro ${ }^{4}$ há uma indicação que Fernando Costa teria um contato com Ricardo Severo, arquiteto defensor da arquitetura neocolonial, o que poderia explicar sua defesa da relação entre o campo brasileiro e este estilo da arquitetura.

Discutimos, a seguir, o projeto original, constante dos acervos do Núcleo de Engenharia da Secretaria de Abastecimento e Agricultura do Estado de São Paulo (NE/SAA) e do antigo Departamento de Obras Públicas (DOP) da Secretaria de Viação e Obras Públicas (SVOP), hoje parte do acervo da Companhia Paulista de Obras e Serviços (CPOS). Serão analisadas as condições geográficas, técnicas e pedagógicas do lugar. As condições geográficas tratadas são principalmente físicas: a conformação do terreno, a adequação ao uso agrário (agrícola e pecuário), a estrutura fundiária anterior à criação da Escola, a hidrografia, o clima e demais

\footnotetext{
${ }^{4}$ MASCARO (2008).
} 
condições ambientais. As

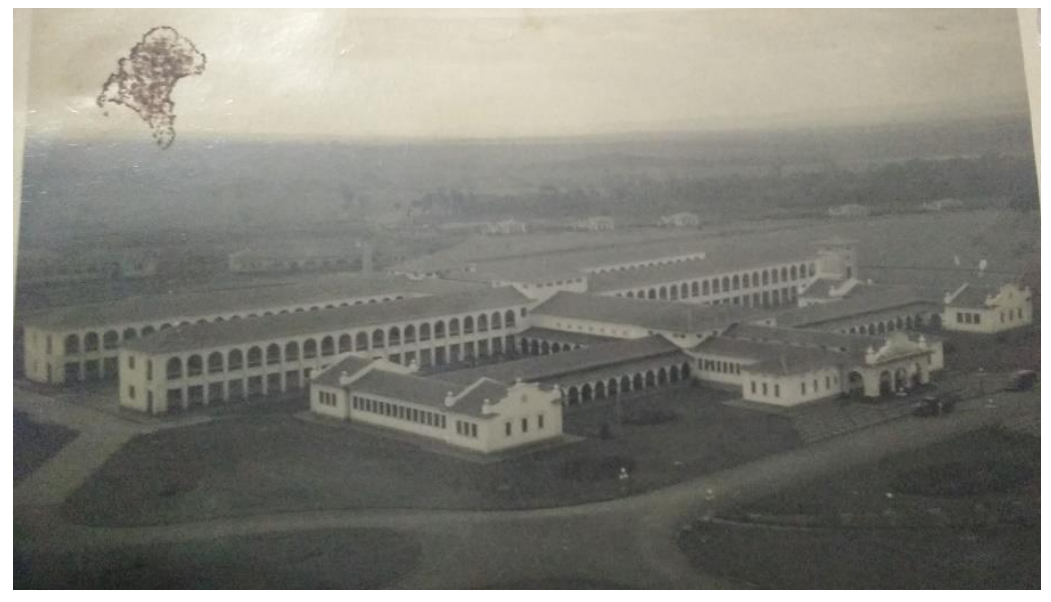

condições técnicas referemse à maneira como o projeto abordou as questões antes apresentadas e as resolveu. Por exemplo, se há um zoneamento, como o programa se distribui no terreno, como se resolveram as

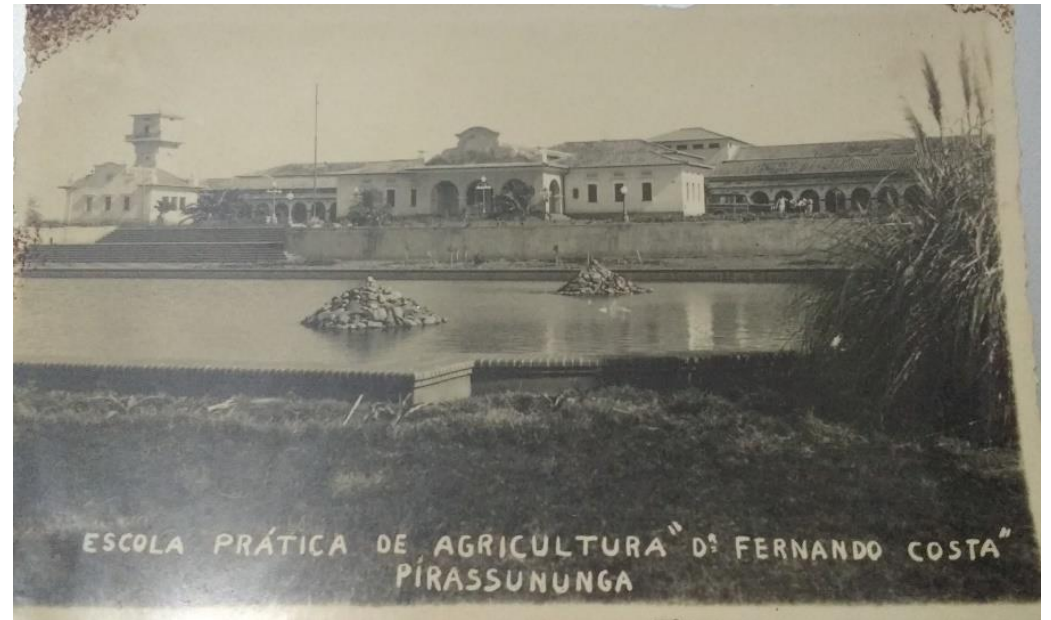

Fonte: Tokugi Tamaki. infraestruturas necessárias para a ocupação, onde se implantaram os edifícios, etc. $E$, finalmente, algumas condições a partir de necessidades pedagógicas que conseguimos resgatar na bibliografia ou observar nos projetos.

Ainda neste capítulo serão apresentados os resultados da pesquisa realizada junto aos acervos do NE/SAA e da CPOS. Consultamos também o Departamento de Recursos Humanos da Secretaria de Abastecimento e Agricultura, que possui em seus acervos os registros dos funcionários antigos da casa. Buscamos a autoria do projeto também em fontes secundárias, como o livro "Agricultura paulista - Uma história maior que 100 anos" ou na tese de doutorado de Luciana Pelaes Mascaro. Esquecida nas últimas décadas, a autoria principal pode ser dedicada aos profissionais da empresa Sociedade Construtora Brasileira S/A, que foi responsável pela construção da Escola em Pirassununga. Essa suposição se fundamenta na observação dos projetos executivos: aqueles que foram efetivamente construídos possuem carimbos da empresa. As assinaturas não são de profissionais das secretarias, portanto deduzimos que são assinaturas de funcionários da empresa ou de escritórios contratados por ela. 
Mais importante que a autoria de um profissional específico, está a discussão sobre os porquês das decisões estéticas ali assumidas. Considerando o poder institucional delegado aos ministros e interventores, no contexto do projeto desenvolvimentista do Estado Novo de Getúlio Vargas, acreditamos que as decisões estéticas do projeto são reflexo das crenças pessoais daquele que representava o poder central, no caso, o político paulista Fernando Costa.

A segunda seção deste capítulo busca interpretar a relação entre a antiga Escola Prática de Agricultura com a Pirassununga da época. No fim dos anos 30 a cidade de Pirassununga era uma pequena cidade do interior, com população pouco inferior a vinte mil habitantes. Durante a gestão do jovem Fernando Costa como Prefeito, a cidade teve um primeiro surto de desenvolvimento, quando foi construído o Instituto de Educação de Pirassununga, por exemplo. Sem nunca abandonar Pirassununga durante sua carreira política, o político Fernando Costa premia a cidade com a instalação da maior das Escolas Práticas de Agricultura. Recepcionada como um símbolo de desenvolvimento, a Escola foi desde então - mesmo considerando seus altos e baixos - um polo de atração de pessoas, tecnologias e investimentos para a cidade; bem como um polo indutor de crescimento físico.

Na terceira seção do capítulo propomos uma contextualização por meio de estudos comparados. Serão confrontados os projetos da Escola Prática de Agricultura em Pirassununga, não apenas por ser o objeto específico desse trabalho, mas também como exemplo das demais, com outras realizações contemporâneas. Primeiramente com a precursora ESALQ e também com Seropédica, Areia e Belém.

O segundo capítulo encerra, portanto, a maior parte da pesquisa documental realizada. Os textos apresentados tentam interpretar esses documentos originais da implantação da antiga Escola Prática de Agricultura. No centro dessa discussão está a personalidade de Fernando Costa, que, desde dezembro de 2015, dá nome ao campus da USP em Pirassununga.

O terceiro capítulo, "Progresso, crise e a chegada gradual da Universidade", trata dos fatos que ocorreram no que é hoje o Campus Fernando Costa da USP e suas relações, tanto com a cidade, quanto com a instituição, além de questões relacionadas à gestão do território. 
A primeiro seção, "O ocaso do ensino agrícola e o projeto de industrialização do campo", se refere à crise que se anuncia nos anos 50, cujas origens estão plantadas ainda nos últimos anos da década anterior. Mesmo sendo um projeto recém-inaugurado, as Escolas Práticas de Agricultura sofrem uma degradação física considerável e um abandono institucional. Em 1956 a Escola Prática de Agricultura é fechada - mas ao mesmo tempo já havia um movimento para sua reabertura em outros moldes.

A ascensão dos grupos adversários ao projeto educacional no campo, nos anos 1950, fez com que as Escolas Práticas de Agricultura perdessem prestígio e progressivamente fossem destinadas a outros usos. A escola de Ribeirão Preto tornarse-ia um campus da USP, abrigando a Faculdade de Medicina. A escola de Pirassununga também seria destinada à USP, porém para abrigar cursos de nível médio, sob os cuidados da Faculdade de Medicina Veterinária, já a partir de 1958 (após a Lei 1763 de novembro de 1957). Outras escolas tornar-se-iam presídios agrícolas ou mesmo demolidas. Nos anos 70 a escola de Itapetininga deixaria de ser um presídio agrícola e voltaria à sua função original - escola em nível médio, função que persiste até hoje.

A transferência da Escola de Pirassununga para a USP permitiu, além da sobrevivência do local como espaço educacional, a manutenção dos espaços físicos, ainda que algumas vezes com cuidados insuficientes. Os cursos técnicos, inaugurados poucos anos antes sob a denominação "Instituto de Zootecnia e Indústrias Pecuárias Fernando Costa", ou IZIP, foram renomeados para CIZIP, ou "Centro Intraunidade de Zootecnia e Indústrias Pecuárias Fernando Costa". Assim sobreviveu até os anos 70 , quando foram inaugurados os cursos de nível superior.

No caso específico de Pirassununga esse período de crise também se refletiu no espaço físico da Escola. Na primeira metade da década de cinquenta aconteceu a construção da Via Anhanguera, o caminho que interliga o centro-oeste do país com a capital paulista ${ }^{5}$. Esta rodovia atravessaria o território da Escola, cindindo-o em duas partes. O trecho apresentado como Parque no capítulo anterior foi completamente descaracterizado. As rotatórias junto ao antigo Ginásio de Esportes e junto ao trevo da área produtiva foram eliminadas. A lagoa de maior área sofreu assoreamento,

${ }^{5}$ REIS (2014), pg. 91. 
tornando-se um charco. Permanece o eixo principal, que dá sentido e interliga todas as regiões da área estudada. Porém no cruzamento deste com a Rodovia é construído um portal, em estilo modernizado (art déco), pouco coerente com o neocolonial préexistente. Essa foi a primeira transformação na paisagem.

Essas idas e vindas institucionais refletem a preponderância das decisões administrativas no gerenciamento do espaço físico, sobrepondo-se às decisões técnicas ou pedagógicas e às questões construtivas ou de interesse paisagístico ou urbanístico. Não apenas a grande transformação do projeto original, que foi a construção da Via Anhanguera sem qualquer respeito pelo traçado pré-existente, mas também na manutenção dos edifícios, alterados sem qualquer critério, como o edifício João Soares Veiga, por exemplo.

O seguinte título " $A$ chegada da USP em Pirassununga" trata deste fato histórico e da gestão desse território como, efetivamente, espaços universitários. A USP se estabelece em Pirassununga inicialmente como escola técnica, por meio do IZIP. Em meados dos anos 70 o Conselho da Faculdade de Medicina Veterinária e Zootecnia (FMVZ), decide instalar um curso superior de zootecnia totalmente abrigado na chamada "fazenda", a fim de melhor ocupar o espaço, enobrecendo-o aos olhos da instituição e da sociedade pirassununguense. A inauguração do curso não ensejou a construção de novos edifícios, já que as aulas práticas eram ministradas nos mesmos locais que o curso técnico. O curso técnico já não recebia mais investimentos. A procura também diminuía e nos anos 80 a decisão da FMVZ foi fechar o curso.

Nos anos 50 e 60 a escola técnica vinculada à USP forma 15 turmas nos cursos técnicos de "indústrias agropecuárias" e "zootecnia". A cidade utilizava os espaços do IZIP, especialmente o atual Centro de Eventos, que abrigava as formaturas, as recepções às autoridades e os eventos de maior formalidade; e o Parque de Exposições, com festas anuais e espetáculos musicais, realizados na arquibancada hoje fechada pela situação precária de manutenção. Os estudantes, quase todos, residiam na própria escola, nas oito alas habitacionais do Prédio Central. Havia intensas relações entre as comunidades do município e do IZIP, ainda que este permanecesse situado em ambiente rural, apesar de relativamente próximo da trama urbana (aproximadamente dois quilômetros até a portaria) ${ }^{6}$.

\footnotetext{
${ }^{6}$ TELES e IOKOI (2005), pgs. 91-118.
} 
O espaço físico da escola técnica era praticamente o mesmo da escola prática. Os dois cursos oferecidos utilizavam as instalações técnicas pré-existentes, embora alguns edifícios tenham sido reformados ou atualizados. O caso mais aparente é o Edifício João Soares Veiga (nome do fundador do IZIP), que teve seus grandes espaços de produção subdivididos pela criação de um corredor central. Além disso, as áreas de produção também foram ampliadas, já que as aulas do Departamento de Nutrição e Produção Animal da FMVZ passaram a ser aplicadas em Pirassununga (e até hoje esse Departamento é lá sediado).

Nos anos 1980 Pirassununga passa a abrigar o recém-instalado curso superior de Zootecnia. A novidade não ensejou o aumento do espaço físico ou construído. Algumas reformas foram realizadas, como a divisão das alas habitacionais do prédio central. Uma prática recorrente até os dias atuais também se inicia nesse período: 0 uso das antigas residências, organizadas em "colônias", para outros fins, como laboratórios. Mesmo abrigando um curso superior integralmente ofertado em Pirassununga, as pressões para uso mais intensivo do espaço não arrefeceram por anos. Abranda-se apenas em 1989, com a inauguração da "Prefeitura do Campus Administrativo de Pirassununga", e em 1992, com a separação da FMVZ e a criação da Faculdade de Zootecnia e Engenharia de Alimentos (FZEA), hoje com quatro cursos de graduação e cinco programas de pós-graduação. Durante as décadas de 1960, 1970 e 1980 essas pressões existiram e pouco influenciaram no desenvolvimento físico do território uspiano em Pirassununga.

Ainda nos anos 1970 acontece a segunda transformação na paisagem: a duplicação da Via Anhanguera. Entre os anos de 1958 e 1970 foi construído um portal, em estilo art déco, no cruzamento dos eixos da rodovia Anhanguera e o eixo principal do IZIP. A obra de duplicação causou a demolição deste portal, a construção de um túnel sob a rodovia e o rompimento visual do próprio eixo principal. A vista progressiva para a grande rotatória ficou interrompida pelo túnel. A drenagem de águas pluviais exigiu algumas obras, com a construção de um pequeno lago, algumas barragens e tubulações.

Para compreender as alterações no espaço físico é mister observamos o impacto na paisagem das decisões institucionais de âmbito universitário. Na segunda metade dos anos 1990, houve uma decisão em ampliar o número de vagas e cursos na USP. Obviamente, essa decisão seria acompanhada da ampliação do espaço 
físico. Nesse período, a ampliação no interior de São Paulo se concentrou em São Carlos (principalmente nos cursos ligados a tecnologia) e em Ribeirão Preto (principalmente nos cursos ligados a saúde, mas posteriormente em todas as áreas). Pirassununga não estava no foco. Mesmo assim as pressões para ampliação foram parcialmente atendidas. A FZEA, que possuía apenas o curso de Zootecnia no momento de sua criação (1992), abriu o curso de Engenharia de Alimentos, previsto desde aquela data, em 2001. E apenas em 2009 abriria dois novos cursos (Medicina Veterinária e Engenharia de Biossistemas) e o programa de pós-graduação em Engenharia de Alimentos. Desde então, ainda abriu três novos programas de pósgraduação.

Essas decisões institucionais, sejam políticas, técnicas, ou decorrentes de pressão social, deveriam ser parte de um planejamento institucional que envolvesse vários componentes: o aspecto social, o aspecto financeiro e o aspecto físico e paisagístico. Na história da USP há surtos de desenvolvimento, após decisões institucionais, que foram desacompanhados desse necessário planejamento. No caso específico estudado, não havia qualquer planejamento para os aspectos físicos e paisagísticos até a conclusão de um Plano Diretor. Esse Plano Diretor foi discutido e desenhado entre os anos de 2007 e 2008 e entregue em janeiro de 2009 para a unidade acadêmica interessada (FZEA). Nesse momento, já existiam contratos prévios com escritórios de arquitetura, que confeccionaram projetos executivos de edifícios, que não faziam parte deste Plano Diretor. Além disso, o Plano Diretor abordava uma área de apenas 13,7 hectares de um total de 2.240 hectares.

O último título deste capítulo refere-se ao Campus Fernando Costa como parte da USP atual. Serão abordadas as últimas intervenções no espaço físico, especialmente na área frontal do campus, onde se encontra com a cidade; e o último surto de desenvolvimento, iniciado na reitoria da professora Suely Vilela e continuada na gestão do professor João Grandino Rodas.

Também, entre 2005 e 2009, ocorre a terceira transformação da paisagem: a duplicação da Avenida Duque de Caxias Norte pela Prefeitura do Município de Pirassununga. O crescimento da cidade no sentido norte, ultrapassando a portaria da USP, ensejou estudos para a duplicação da principal (e na época, a única) via de acesso a essa região da cidade, que já continha quase 10.000 habitantes e prosseguia se adensando. A solução executada exigiu a demolição parcial do portal do acesso, 
edifício marcante, símbolo da USP em Pirassununga e logotipo da Prefeitura do Campus, mesmo após sugestões alternativas recomendadas por especialistas. Novamente, decisões institucionais pouco transparentes se sobrepõem a qualquer planejamento, mesmo aqueles realizados com urgência. A decisão, nesse caso, passando por gabinetes, negava uma alternativa técnica que observasse a manutenção do edifício do Portal na íntegra, ou até valorizando-o.

Finalmente, com relação à expansão recente da USP em Pirassununga, serão apresentadas as intervenções e algumas constatações possíveis: a área que foi objeto de planejamento está relativamente organizada, com elementos executados e outros ainda planejados, além de algumas intervenções pontuais não previstas, menos significativas. O plano é entendido como processo, sendo modificado e atualizado com alguma frequência e observado pelos dirigentes dos órgãos e pelos técnicos responsáveis. As áreas que não foram abordadas pelo plano seguem sendo alteradas conforme decisões institucionais, tomadas pelos dirigentes e líderes locais, com pouca ou nenhuma consideração técnica e pouca ou nenhuma visão de conjunto. As unidades enxergam seus territórios sem considerar a vizinhança e a pré-existência de infraestruturas similares, os laboratórios idem, e assim esse pensamento do "lote" e da "propriedade" vai se reproduzindo e produzindo o espaço.

Encerra a dissertação um capítulo à guisa de conclusão, que aborda as dificuldades e perspectivas dos territórios universitários em ambiente rural. As dificuldades por serem territórios pressionados a atender demandas muito específicas da sociedade, que a vinculam diretamente com os interesses da universidade operacional, que está interessada em conceitos como eficácia, produtividade e consumo. As perspectivas por serem territórios com rica história e qualidade ambiental e que apresentam crescente diálogo com a cidade que se aproxima. Apresentamos como propostas algumas diretrizes de planejamento que, neste trabalho, se aplicam especificamente ao Campus Fernando Costa da USP. Diretrizes ainda muito amplas, mas que pretendem aproximar esses territórios dos conceitos de uma universidade mais democrática e próxima da população da cidade, sem perder a importante identidade institucional. 


\section{CAPÍTULO 1}

\section{Territórios universitários}

Este capítulo trata dos temas que concernem ao período anterior da fundação da Escola Prática de Agricultura em Pirassununga. É um capítulo histórico, que procura revisar a bibliografia existente e preparar para as questões específicas desta Escola. $O$ texto se inicia com um relato das experiências de planejamento de territórios universitários no mundo e alguns casos no Brasil, seguido de um brevíssimo histórico das universidades latino-americanas e as fases preliminares da fundação das universidades no Brasil. A seguir apresentamos um panorama que aproxima os espaços de caráter rural da historiografia geral do tema. Apresentamos ainda uma discussão etimológica sobre os termos campus, cidade universitária e territórios universitários. Concluímos apresentando as condições efetivas que permitiram a fundação das duas instituições que essa Dissertação enfoca: a Universidade de São Paulo e a Escola Prática de Agricultura.

\subsection{Questões de planejamento dos territórios universitários}

\subsubsection{Historiografia do tema}

Antes de abordar especificamente as questões de planejamento dos territórios universitários, faz-se necessário apresentar as principais referências bibliográficas que trataram do tema. Os autores principais que aparecerão nesse texto são Richard Dober, Stefan Muthesius, Paul Turner e Thomas Bender, cujos textos embasam os estudos sobre os espaços ocupados pelas universidades. Além deles, outros autores que lidaram com o tema são Thomas Gaines, Perry Chapman, Daniel e Ginger Kenney e Jonathan Coulson com Paul Roberts e Isabelle Taylor. No Brasil, há o livro de Esther Buffa e Gelson Pinto, além de textos mais específicos, tratando de períodos determinados ou instituições em específico. Cada um deles será referenciado a seguir. 
Richard Dober foi um arquiteto norte-americano, projetista e planejador, cujos clientes em sua maior parte foram instituições de educação de nível superior. Seu trabalho o destacou a ponto de tornar-se a maior referência em planejamento de espaços universitários, sendo convidado para proferir palestras ao redor do mundo. Seu título de 1963 (Campus Planning) é a primeira obra de grande alcance no tema. Trata-se de um manual com três partes. A primeira parte inclui uma visão geral do tema, um histórico de planejamento físico universitário e um texto com conceitos gerais. A segunda parte trata de componentes isolados de um campus universitário e a terceira trata dos componentes de um plano. Essas duas partes provavelmente são precursoras do seu título posterior (Campus Landscape). O livro tem grande repercussão e é citado em diversas obras presentes nesta bibliografia. A introdução é essencial para a compreensão do que os autores norte-americanos consideram como "planejamento físico", bem como a indissociabilidade do "planejamento financeiro". O texto de 2000, nas palavras do autor, é "um livro que oferece informações, ideias e instruções sobre planejar e projetar um espaço verde que situa, serve e simboliza a educação superior". Em nossa opinião, é um manual muito bem organizado sobre tópicos que compõem uma paisagem típica de campus universitário, com exemplos, imagens, gráficos, diagramas, etc. Organiza-se em duas seções: uma com os determinantes da paisagem (como clima, vegetação, etc) e outra com a taxonomia de projeto. Essa taxonomia se divide em: criando um lugar distinguível; promovendo encontros; espaços; jardins, lugares para educação, entretenimento e iluminação; marcos do lugar e objetos do usuário. Resumidamente, é um manual, escrito pelo nome mais conhecido em planejamento de campus universitário, com atuação no país que é precursor nesse tipo de espaço.

O inglês Stefan Muthesius é professor honorário da Universidade de East Anglia, onde foi docente nas áreas de história da arte e da arquitetura ${ }^{7}$. Sua farta produção está arquivada na biblioteca principal da Universidade. Seu título de 2000 (The Postwar University: Utopianist campus and college) é livro de importância inquestionável no tema. O autor traça um detalhado histórico de realizações no período pós-guerra, contextualizando as práticas e vinculando as ações no espaço físico com as discussões pedagógicas e institucionais em voga em cada país e

\footnotetext{
7 É filho de Hermann Muthesius, que foi uma figura chave da arquitetura alemã no princípio do século $\mathrm{XX}$, integrante da Deutscher Werkbund e entusiasta do movimento arts and crafts.
} 
momento descritos. Sua pesquisa é uma verdadeira busca pelos critérios que permitam o desenvolvimento de um campus utopianista - ou seja, um lugar que mire a utopia, mas factível.

O norte-americano Paul Venable Turner é professor emérito na Universidade Stanford, onde lecionou história da arte e da arquitetura. Seu título de 1984 (Campus: An american planning tradition) venceu o prêmio de melhor livro de história da arquitetura no ano de seu lançamento. É o maior autor de publicações sobre o assunto. Além das diversas obras publicadas, redigiu palestras, capítulos de livros, artigos, etc. No título de 1984 reconta a história dos territórios universitários nos Estados Unidos (com introdução contextualizada geograficamente), com base em extensa pesquisa historiográfica. Esse texto é citado por vários dos autores aqui referenciados.

Thomas Bender é professor de história medieval na Escola de Artes e Ciências da Universidade de Nova Iorque (NYU). É estudioso de história das cidades e coordenou uma conferência internacional sobre a relação entre cidade e universidade por ocasião do centenário da NYU, em 1986. Tendo como referencial a história cultural, essa conferência foi depois transposta para o formato escrito e apresentada como livro (The University and the City: from medieval origins to the present). Reúne artigos que são referência para o estudo da relação entre universidade e cidade.

Thomas Gaines foi um historiador de arquitetura norte-americano, cuja fama se deve principalmente ao título "The Campus as a Work of Art". O autor argumenta que campus universitário é um tipo de produção humana que pode ser comparada às obras de arte e procura estabelecer quais seriam as características principais que um campus universitário deveria possuir para ser classificado como tal. O texto é construído com base em estudos de casos e análises de lugares específicos, na maioria das vezes fazendo uso de estudos comparativos. O material apresentado é relevante por causa desses exemplos e estudos, já que o objetivo do autor, além de defender a ideia de que campus são obras de arte, é estabelecer um ranking dos melhores campi - a título de curiosidade a lista é liderada, na ordem, por Stanford, Princeton, Wellesley, Colorado, Indiana em Bloomington, Evergreen, Columbia, Mount Holyoke, RIT, SUNY em Albany.

Perry Chapman foi outro autor praticante, tendo consolidado sua vida profissional em um escritório de arquitetura e planejamento. Como poucos, reuniu 
teoria e prática. Por exemplo: sua abordagem de integração entre campus, natureza e cidade aparecia em seus projetos e em seu título de 2006 (American Places: In Search of the Twenty-First Century Campus). Além disso, dirigia-se ao trabalho em bicicleta, até sua aposentadoria. Centraliza seus esforços em uma visão que recentemente ganha muita força no meio acadêmico dos Estados Unidos: a compreensão que o espaço físico da instituição representa muito mais do que o lugar onde as atividades acadêmicas acontecem, mas também é o lugar onde o aprendizado se confirma, as memórias dos estudantes se fixam e a identidade da instituição se consolida. Invocando a tradição norte-americana em campus universitário, o autor reúne argumentos para ajudar na composição de uma proposta para o campus do século vinte e um. Aborda, por exemplo, a questão da relação entre o espaço físico e o espaço virtual; a participação da comunidade no processo de planejamento; a internacionalização da universidade; a era do empreendedorismo; e dedica uma parte do livro para a questão ambiental, sobre a qual necessariamente abordaremos, visto a especificidade do objeto desta pesquisa (campi universitário com grandes extensões de terra).

Coulson, Roberts e Taylor são arquitetos, funcionários de dois importantes escritórios ingleses. Juntos escreveram um recente título (2011, denominado University planning and architecture: The search for perfection), publicação que é dividida em duas partes: a primeira é um histórico do ambiente universitário (aqui denominado campus), com foco nas experiências mais inovadoras e pioneiras não apenas no campo da arquitetura, mas principalmente no arranjo espacial do campus em si. A segunda parte é um compêndio de estudos de casos de campus universitário ao redor do mundo, com breve histórico da instituição e uma explicação dos motivos que permitem aos autores afirmar que o campus é um caso de sucesso, reunindo características inovadoras no âmbito da arquitetura e urbanismo.

Há outros títulos e outros autores que escreveram sobre o tema e que poderiam estar presentes nesse pequeno compêndio, no entanto essa pequena seleção nos parece incluir os textos essenciais que explicam a história dos territórios universitários. 


\subsubsection{Considerações sobre planejamento físico-territorial das universidades}

Na introdução de "University and the City", Thomas Bender escreve uma bela frase que relaciona a universidade e a cidade e suas mútuas influências, em especial em tempo de crise ${ }^{8}$. Ele afirma que, algumas vezes, a universidade foi salva da crise pela dinâmica que a circundava (na cidade), enquanto em outras oportunidades a universidade oferecia um foco e um princípio de coerência para a vida cultural da cidade. Para a cidade há vasta produção intelectual sobre as questões de planejamento físico. Porém não são muitos os trabalhos que relacionam 0 planejamento físico com a universidade. A seguir serão apresentadas algumas notas que resumem a evolução deste tema na história.

Turner (1984) apresenta os primeiros textos referentes ao planejamento dos territórios universitários, datados de 1897 a 1903. Durante o processo de transformação que as universidades norte-americanas passaram, fundindo o antigo modelo (colleges e campo) com o modelo humboldtiano, alguns autores argumentavam que essas instituições não poderiam mais ser compostas por edifícios isolados sem qualquer conexão entre eles, tanto do ponto de vista arquitetônico quanto do ponto de vista urbano. Assim surge o planejamento dos territórios universitários - pelo menos de maneira intencional. Esses argumentos reproduziam os termos "arte" e "unidade", além de ressaltarem a importância da "cultura" e do "aprendizado" entre os valores da sociedade daquele país. Além disso há a preocupação administrativa, ou "como" gerenciar espaços tão diversificados e com finalidades tão variadas. Mas, de maneira geral, a principal preocupação dos articulistas da época era predominantemente formalista e visual. Os planos globais (ou comprehensive plans, no termo original) compreendiam, basicamente, uma lista de demolições e a progressiva construção de edifícios de determinado estilo arquitetônico criando eixos e pontos focais, dentro de uma cultura imersa no movimento "City Beautiful" 9 . Um exemplo de plano desse período para uma instituição nova é a Universidade de Chicago (figura 2). Situada a 11 quilômetros da área urbanizada naquele tempo, foi integralmente projetada para um período muito amplo,

\footnotetext{
8 BENDER (1988), pg. 4.

9 TURNER (1984), pg. 164 e MUTHESIUS (2000), pg. 25.
} 


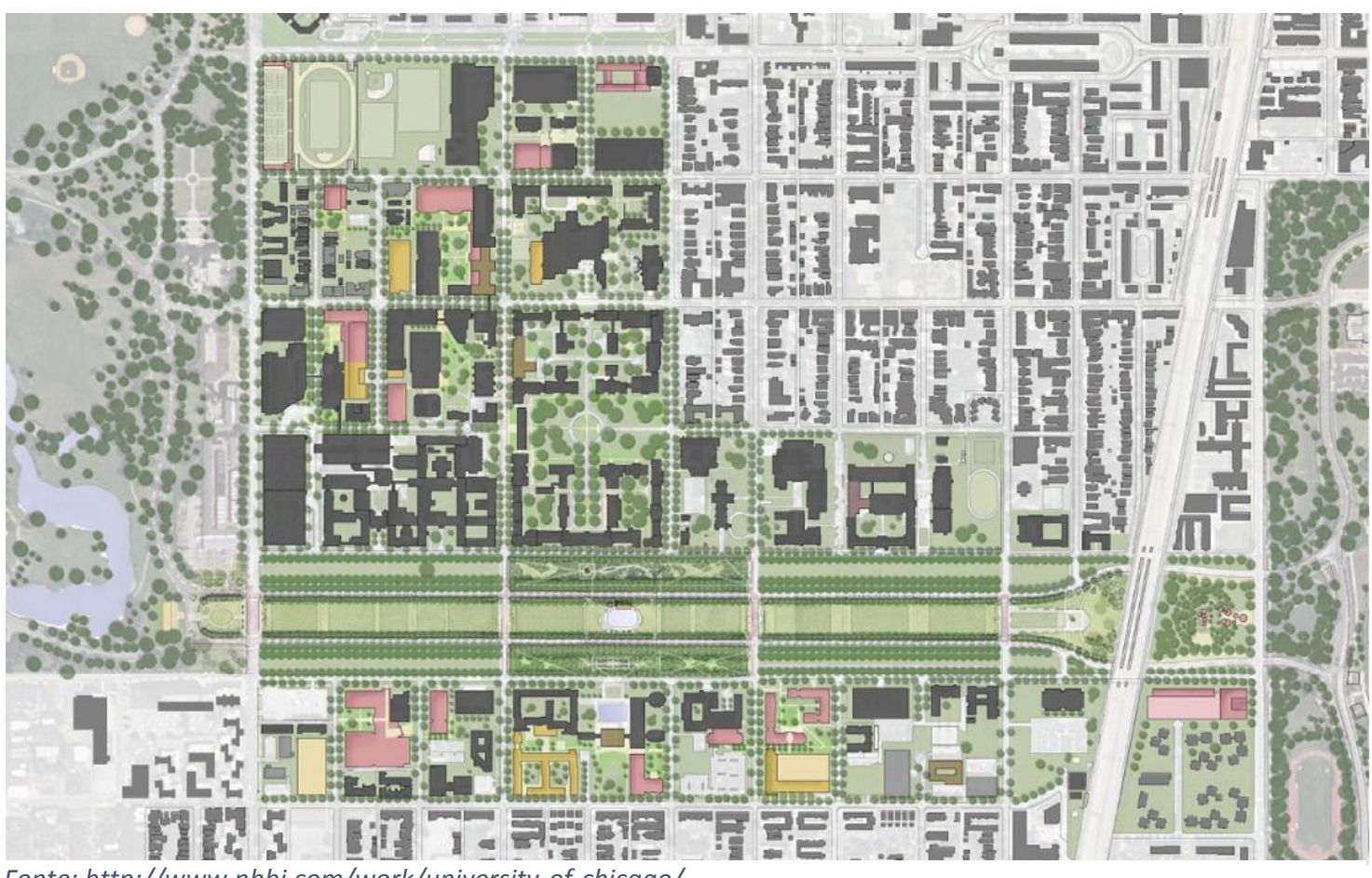

Fonte: http://www.nbbj.com/work/university-of-chicago/

em uma área de proporções igualmente amplas ${ }^{10}$.

Além disso, a cada vez maior participação de instituições públicas no ensino superior ensejou a maior influência de visões políticas no planejamento dos espaços - o que irá ter relevância bem maior no caso brasileiro do que nos países citados até o momento, como veremos.

O modernismo, principalmente após a segunda grande guerra, trouxe novas propostas para novos problemas. Ao mesmo tempo, a instituição universitária se transforma e populariza-se, servindo como um centro de desenvolvimento de tecnologia e tornando-se mais acessível para maiores parcelas da população. $O$ desenvolvimento da tecnologia exigia flexibilidade nos espaços físicos, o que os velhos modelos arquitetônicos não poderiam oferecer. $\mathrm{E}$ o crescimento demográfico exigia novos sistemas construtivos, cujos prazos de construção pudessem ser muito menores e seriados. Esses dois problemas, flexibilização dos espaços e sistema construtivo "racional", foram abordados pelos arquitetos e urbanistas do modernismo desde seus princípios, ainda nos anos 1920 e 1930. Um terceiro problema foi a popularização do automóvel individual na sociedade norte-americana, que impactou

10 COULSON, ROBERTS e TAYLOR (2011), pg. 159. 
de maneira crucial o planejamento dos territórios universitários. A priorização da relação entre leito carroçável e edifício contra a relação calçada e edifício é o aspecto mais visível da sociedade do automóvel individual.

Os primeiros exemplares de campus modernistas nos Estados Unidos são resultado da chegada dos professores da Bauhaus, a famosa escola alemã fechada na ascensão Hitlerista. Walter Gropius foi convidado para ser docente em Harvard em 1937, onde desenvolveu um master plan e alguns projetos de arquitetura; e Mies van der Rohe foi para o Illinois Institute of Technology (IIT), para ser docente e também autor do planejamento físico da instituição (e do projeto da faculdade de arquitetura), conforme figura 3. Walter Gropius tentou invocar o modernismo europeu sem romper com a tradição do american campus, especialmente no tocante à relação entre arquitetura e as questões socio-pedagógicas ${ }^{11}$. Já Mies van der Rohe, à partir de 1940, no IIT, projetou 20 obras em um plano base quadriculado em uma base de $24 \mathrm{x}$ 24 pés (o equivalente a aproximadamente 7,30 x 7,30 metros), típico do modernismo da Bauhaus, modular e geométrico ${ }^{12}$.

Figura 3: Illinois Institute of Technology

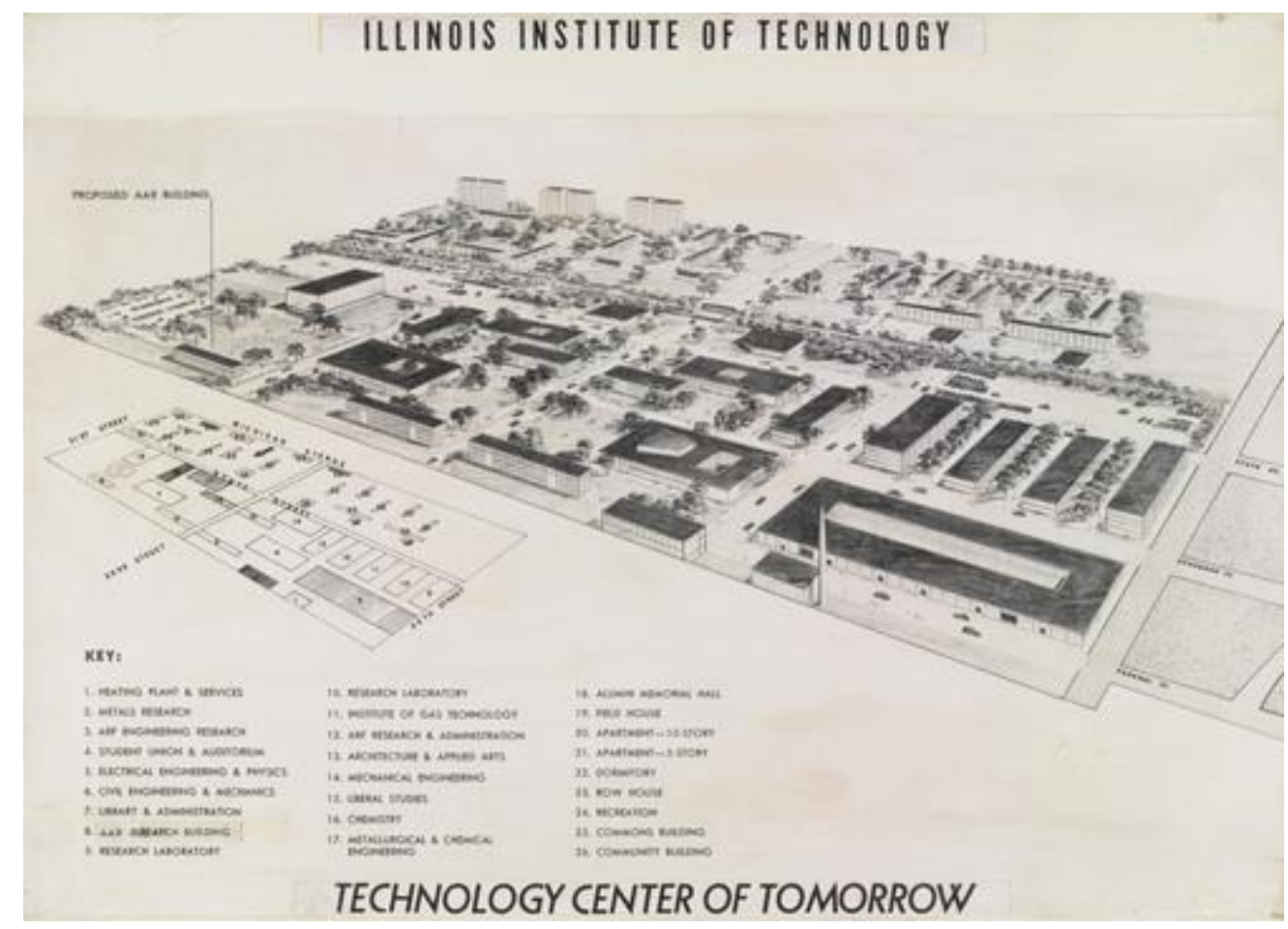

Fonte: http://chicago.curbed.com/2015/3/27/9981636/iit-architectural-history

\footnotetext{
${ }^{11}$ MUTHESIUS (2000), pg. 33.

${ }^{12}$ ADELYN PEREZ (2010).
} 
Mais importante do que as características tecnológicas ou formais dos espaços construídos, foi a diferente concepção sobre como proceder para atender essas novas demandas impostas no pós-guerra. Os profissionais arquitetos e urbanistas deixaram de ser exclusivos no processo de confecção dos planos de territórios universitários. Profissionais de outras áreas, como administradores, sociólogos e engenheiros foram encorajados a tomar parte nos planos, contribuindo para uma visão menos formalista dos planos. Dados como crescimento demográfico, número de matrículas, planos acadêmicos e matrizes financeiras passaram a ser primordiais para o planejamento dos territórios universitários, ao lado da topografia, dos estilos arquitetônicos e a disposição das edificações ${ }^{13}$. O uso do zoning, desde as primeiras décadas do século utilizado em planejamento urbano, também se torna recorrente ${ }^{14}$.

O manual de Richard Dober, escrito em 1963 e referência utilizada ao redor do mundo até os dias de hoje, é uma relevante prova dessa nova abordagem. Richard Dober foi consultor da Educational Facilities Laboratories Inc., apoiada pela Ford Foundation para aprimorar o planejamento de territórios universitários, e sócio da Dober, Walquist and Harris Inc., empresa de consultoria. É dividido em três seções. A primeira é uma introdução histórica e a explicação geral de como utilizar o manual, na qual define que programa mais projeto é o planejamento em si; e que o plano deve ter uma representação física, como um mapa. A segunda parte trata dos componentes de um campus, como edifícios de ensino, bibliotecas, museus, edifícios de pesquisa, centros de vida extracurricular, habitação, instalações esportivas, circulação, estacionamentos e facilidades. A terceira parte organiza esses componentes, tratando do crescimento do campus, a organização para o planejamento, levantamento de dados, zoneamento, renovação de campus pré-existentes, e o plano em si ${ }^{15}$.

O propósito do plano, cuja fase final é denominada Final Development Plan, ou Plano de Desenvolvimento Final, seria estabilizar a estrutura projetual geral; estabilizar o controle de planejamento e projeto das edificações a construir no futuro

13 TURNER (1984), pg. 266.

14 MUTHESIUS (2000), pg. 25.

15 DOBER (1963). Sobre o autor, é importante informar que não se tratava exatamente de um modernista. Ainda que assuma algumas características desse movimento, como a racionalização construtiva, por exemplo, também tem influência de alguns elementos de Kevin Lynch e Gordon Cullen, em design urbano. Ambas influências são perceptíveis em seu título Environmental Design, de 1969 [DOBER, R. P. Environmental Design. Nova Iorque: Van Nostrand Reinhold, 1969]. 
e identificar os edifícios a projetar na primeira fase de implantação do plano. Entre os exemplos apresentados (Dober faz a ressalva que eram muito recentes, apenas parcialmente implantados), alguns planos possuíam nível de detalhe superior ao citado "controle de planejamento e projeto de edificações a construir no futuro" 16 . Destaca-se ainda menções na organização social da população, por exemplo, na separação da moradia dos estudantes solteiros e casados. E há grande destaque para a importância da presença do verde, dos jardins. Sobre a arquitetura, Dober relativiza a importância dos "estilos", mas tem certo destaque o modernismo (enquanto simples padrão estético). Há uma relativa separação entre arquitetura e planejamento.

Outra questão ascendente no pós-guerra foi a efetividade dos planos globais ou comprehensive plans. Os dirigentes questionavam a dificuldade de executá-los na íntegra; a rigidez formal; e a pouca flexibilidade tanto do plano quanto das edificações previamente desenhadas (algumas vezes com décadas de separação entre plano e execução). Por esses motivos a prática de planos globais foi gradualmente substituída por uma prática cuja ênfase seria determinar os "princípios para o futuro crescimento", permitindo que a instituição evolua, mas guiada de maneira mais orgânica, menos rígida ${ }^{17}$.

Essa nova concepção, mais aberta e permissiva, coincidiu com um momento de grande expansão das universidades. Diversas instituições realizaram obras inovadoras, de grande escala e Figura 4: Projeto residencial de Alvar Aalto para o MIT qualidade quase indiscutível. Arquitetos do porte de Alvar Aalto (figura 4) e Eero Saarinen, no Massachusetts Institute of Technology e na Universidade de Chicago, Louis Kahn e Gordon Bunshaft (em Yale), SOM - Skidmore, Owens and Merril (na Academia da Força Aérea dos EUA e na

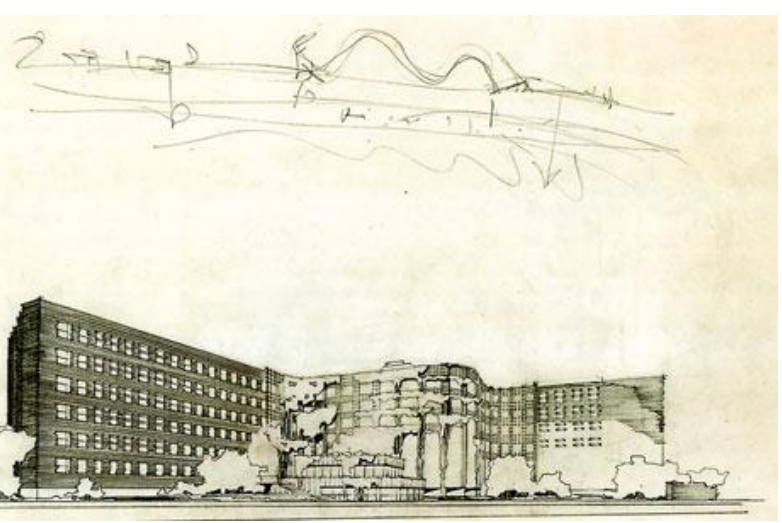

Fonte: http://www.studiointernational.com/index.php/aalto-andamerica
16

(1963), pgs 289-307.

17 Turner cita Joseph Hudnut, que introduziu a arquitetura moderna em Harvard. Resumidamente, em 1947 Hudnut entendia que a universidade é um organismo crescente, que em parte se apoia no passado e em parte no futuro, jamais estando completa. TURNER (1984), pg. 260. 
Universidade de Illinois em Chicago, ambas influenciadas por Mies Van der Rohe) apenas como exemplos, erigiram algumas de suas principais obras nesse contexto. Para Turner, em uma visão conservadora, esse período modernista é uma espécie de retorno às origens do padrão norte-americano, anterior aos primeiros textos sobre planejamento de territórios universitários e ao formalismo do padrão City Beautiful. Já Muthesius lembra que a "arquitetura de edificações" é incongruente ao modernismo e isso pode denotar uma certa submissão dos arquitetos a um nível inferior, no qual participariam apenas de maneira subsidiária do desenvolvimento da universidade ${ }^{18}$.

Figura 5: Universidade de Nova lorque em Albany

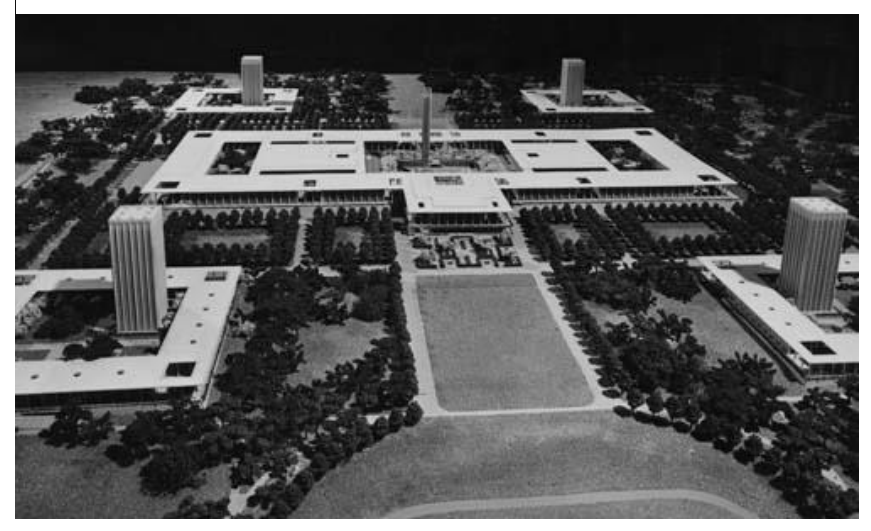

Fonte:

http://www.atmos.albany.edu/geology/webpages/sunyageo.html

Figura 6: Modelo digital do módulo da Universidade de Nova lorque em Albany

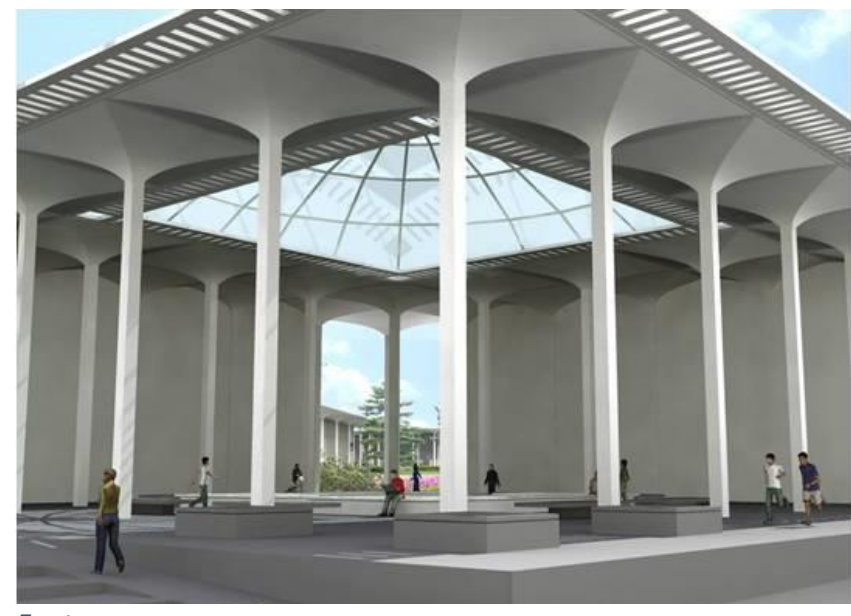

Fonte:

http://www.atmos.albany.edu/geology/webpages/sunyageo.html
Obviamente há exceções. Por exemplo, a Universidade de Nova lorque em Albany (figura 5), projetada e construída em menos de cinco anos para abrigar dez mil estudantes, teve como princípio construtivo a repetição de um módulo de 41 centímetros de lado (figura 6), mas ocupava um único terreno, sem acesso para veículos e com edifícios que não se diferenciam conforme o uso, algumas vezes verticalizados ${ }^{19}$.

Do período modernista resultam instituições muito maiores do que os antigos colleges que deram origem ao modelo norte-americano de ensino superior. Em alguns casos instituições agrupavam populações enormes, de dezenas de milhares de pessoas. Em contraponto a essa realidade,

18 Nos Estados Unidos a função de arquitetos está tradicionalmente separada do planejamento, que configura uma outra atividade e profissão. O autor questiona porque no caso dos territórios universitários, por sua escala ser intermediária entre o planejamento e o desenho urbana (este sim função de arquitetos), essa posição subsidiária é típica do período - e essa visão do autor é crítica aos arquitetos. MUTHESIUS (2000), pgs. 28-31.

19 MUTHESIUS (2000), pg. 44. 
algumas experiências foram realizadas para reunir características positivas do antigo modelo (como a proximidade do aluno com seus pares, o senso de responsabilidade sobre o território, etc) e as vantagens advindas da grande escala ${ }^{20}$. Essa possibilidade também não foi fundamentada simplesmente por questões formais ou urbanísticas, mas também administrativas e acadêmicas. As instituições menores permitem um melhor acompanhamento dos alunos, oferecendo-lhes mais liberdade; permitem a formação de uma mentalidade menos competitiva; e a formação de um corpo cultural mais denso.

Figura 7: Universidade da California em Santa Cruz

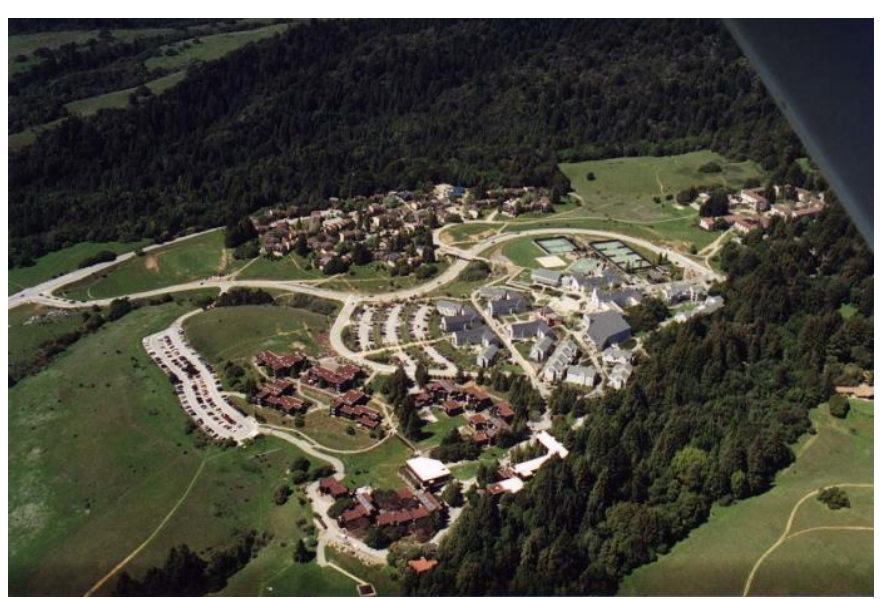

Fonte: https://br.pinterest.com/pin/444308319457540024/
Nesse contexto ainda se inclui uma revalorização do contato com a natureza, em uma perspectiva preservacionista, já premeditando a difusão do termo sustentabilidade. Os melhores exemplos são as expansões e novos territórios da Universidade de Califórnia, e mais especificamente o Campus de Santa Cruz (figura 7). As estratégias adotadas eram, principalmente: o zoneamento; a adoção de clusters que dividiam o mesmo uso em fases de implantação sem ampliações de edificações; a priorização da escala humana na atividade projetual; o melhor aproveitamento das paisagens. Muitas dessas características são retomadas do ideário da cidade-jardim, e não apenas seus aspectos de circulação, estéticos ou formais, mas também suas estratégias de crescimento ${ }^{21}$.

Finalmente, as questões pedagógicas e institucionais também se cambiaram no período. A adoção das universidades norte-americanas pelo modelo organizacional alemão resultou na criação de "Liberal Arts Colleges", que agrupavam cursos de humanas, por exemplo. Essas unidades universitárias se caracterizam por uma significativa liberdade na escolha dos currículos pelos alunos. Outro exemplo eram algumas instituições ou unidades que pregavam grande democracia na gestão, como

\footnotetext{
20 TURNER (1984), pg. 281 e MUTHESIUS (2000), pgs. 49-52.

21 MUTHESIUS (2000), pg. 49.
} 
em Bennington College. Apesar dos movimentos sociais de revolta dos anos 60, com grande impacto na Europa e América Latina, terem difusão extensa nos Estado Unidos, ali não houve uma reforma universitária propriamente dita. As universidades deste país, segundo Muthesius, viviam constante reforma e se ajustavam às necessidades sociais e mercadológicas constantemente, além do desejo reformista ser sombreado pela dicotomia entre a realidade elitista da universidade e sua busca ideológica por igualdade ${ }^{22}$.

A questão que Muthesius coloca, referindo-se ao caso norte-americano, é que o discurso recorrente no meio dos arquitetos no fim do período de expansão (até os anos 1970's) era bastante fechado e chega a citar Turner para comprová-lo. Segundo ele, há uma ênfase exagerada na arquitetura, eclipsando a importância de outras abordagens, como o plano físico e a própria missão da instituição. A compreensão dos educadores sobre a arquitetura também negligenciava as possibilidades da arquitetura. Nesse aspecto, coloca a práxis norte-americana em patamares inferiores à prática europeia ${ }^{23}$.

Em oposição a essa realidade, o planejamento das novas universidades inglesas partia de uma interpretação da vida do estudante não apenas em suas práticas acadêmicas, mas também em vários outros aspectos de sua vida. O estado de bem-estar social vigente nos anos 1960 em boa parte da Europa (e na GrãBretanha) previa o aprimoramento da educação e o acesso à universidade como parte de sua proposta de inclusão social, sob uma perspectiva de superação de paternalismos e oferta de igualdade de condições para os jovens ${ }^{24}$.

A solução adotada para a configuração espacial destas novas universidades foi tipicamente urbana, mesmo considerando que as sedes estavam situadas fora dos perímetros urbanos (mas próximas a eles). Ainda que identificáveis como unidades de planejamento, os territórios universitários receberam abordagens integrais, mas com diferenças frente aos projetos modernistas norte-americanos: o zoneamento e a separação de funções foram evitados. Em partes, essa abordagem se diferenciava pela absorção da crítica às new towns inglesas do pós-guerra, como a baixa

\footnotetext{
22 Id., pg. 18.

23 Ibid., pg. 56.

24 Ibid., pg. 86.
} 
densidade e a monotonia das paisagens. Outros aspectos demarcaram o período: o planejamento das massas edificadas nos moldes de centros urbanos, a pedestrianização, a relação do todo com a cidade que o envolve, adoção de plataformas ou pontes, etc. O resultado dessas composições assemelha-se com pequenas cidades, ainda que não utilizem tal denominação (cidade universitária). Com relação ao contato dos novos territórios universitários com a cidade ao redor, é preciso definir sua situação suburbana. Por dois motivos as universidades não se instalaram exatamente no centro urbano: a visão ainda predominante de um lugar idílico e arborizado (ainda que muito mais densamente edificado que as contrapartes norte-americanas) e, mais importante, a pré-existência de alguma grande edificação histórica para sediar a administração. Ademais, uma boa localização poderia ser útil para atrair o melhor estafe acadêmico ${ }^{25}$.

Os arquitetos que projetaram as novas universidades não eram especialistas em projetos dessa natureza. Aliás, especialidade que só era disponível nos Estados Unidos, pois ao redor do mundo os planejadores de cidades, em geral, seriam os profissionais mais qualificados para esse tipo de intervenção. Uma característica daquele país é que a figura individual do arquiteto não necessariamente se destacava como o "artista" inspirado, produzindo então uma arquitetura comprometida socialmente - o que é uma tradição desde Unwin, por exemplo, utilizando um design legível para a média da população, construída velozmente e, principalmente,

Figura 8: Universidade de East Anglia

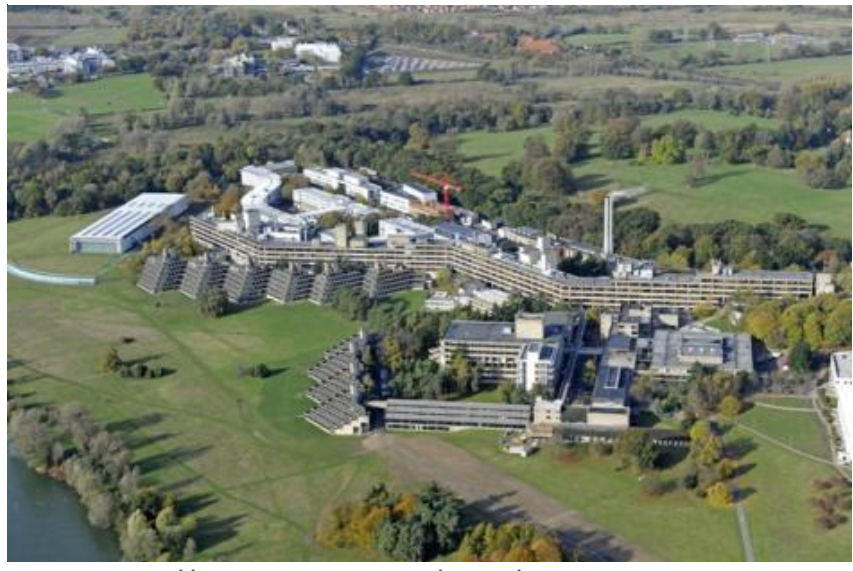

Fonte: https://www.linkedin.com/pulse/university-east-anglialasduns-legacy-marcel-krenz reduzindo sobremaneira os custos da implantação da obra. Ideias previamente definidas foram denunciadas. A relação entre arquitetura e urbanismo foi renovada, pelo menos naquele contexto nacional 26. Todas essas características se identificam nos projetos das novas universidades (figura 8$)^{27}$.

\footnotetext{
25 Ibid., pg. 91-96.

26 COULSON, ROBERTS e TAYLOR (2011), pg. 170.

27 Ibid., pg. 106.
} 
As críticas surgiriam no contexto das manifestações de 1968. O que seriam justamente características positivas e almejadas pelos fundadores das novas universidades inglesas foi também apontado como fatores que permitiram a insurgência: a densidade caracteristicamente urbana e a arquitetura modernista. De acordo com os críticos contemporâneos, esses territórios não permitiam a perfeita vida em comunidade, uma vida integral, mas apenas a impessoalidade e a produtividade nas atividades acadêmicas ${ }^{28}$. Considerando a grande parcela dos estudantes que residiam nesses territórios, a crítica até que pode ser válida, mas a comparação com a vida nos bairros de classes sociais inferiores nas cidades ou em bairros suburbanos distantes do centro (tal qual essas universidades) mitiga sobremaneira a validade da crítica. Ademais, os tempos também mudavam: o Estado de bem-estar social estava em crise. Muthesius define que:

...we deal sistematically with the correspondences between utopian hopes in housing and town planning and utopianism in university planning. The same parallels apply to the negative story. ${ }^{29}$

Com relação às novas universidades alemãs pós-reforma universitária, pelo menos naquelas "de massas", algumas estratégias comuns podem ser identificadas: grandes áreas edificadas interligadas por espaços de convivência e compartilhamento de atividades; um grande auditório ocupa o centro do território (Auditorium Maximum)

Figura 9: Universidade de Bochum

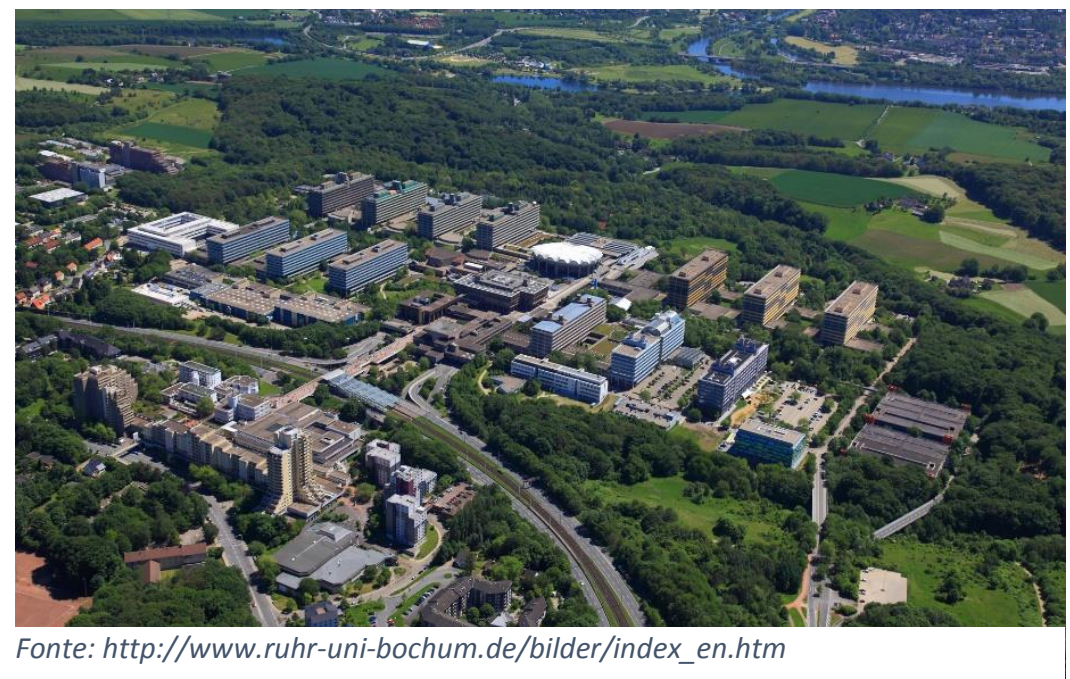

e a implantação é suburbana, em grandes áreas arborizadas (conforme figura 9). Gravitando ao redor dessas áreas de convivência se situam as áreas de usos específicos, como os institutos e faculdades ${ }^{30}$.

28 Ibid., pgs.180-181.

29 Em tradução livre: "lidamos sistematicamente com as correspondências entre os desejos utópicos em habitação e planejamento urbano e utopianismo em planejamento universitário. O mesmo paralelismo se aplica à história negativa".

30 Bochum, Regensburg, Konstanz, Bielefeld, que apesar dessas similaridades espaciais possuíam 
Sobre as universidades francesas, a crítica de 1968 também recaiu sobre o espaço físico. Em primeiro lugar, sobre a rigidez das recentes expansões, construídas sob um conceito modernista axial e de pouca flexibilidade. Em segundo lugar, a falta de conexão com a cidade, os centros comerciais, etc, transformando os territórios universitários em "bolhas" que voltavam-se para si mesmas. Não diretamente relacionado ao espaço, mas com implicações sobre, havia também a crítica sobre a falta de processo participativo no planejamento dos territórios universitários e da própria instituição. Essas críticas foram parcialmente atendidas pelo Estado (as universidades francesas são estatais) ${ }^{31}$. Para este trabalho, importa destacar que a crítica era por maior "urbanidade" nos territórios universitários, e a própria existência dos protestos tinha na origem esse afastamento da cidade. O curioso é que após uma

Figura 10: Universidade de Paris - Tolbiac

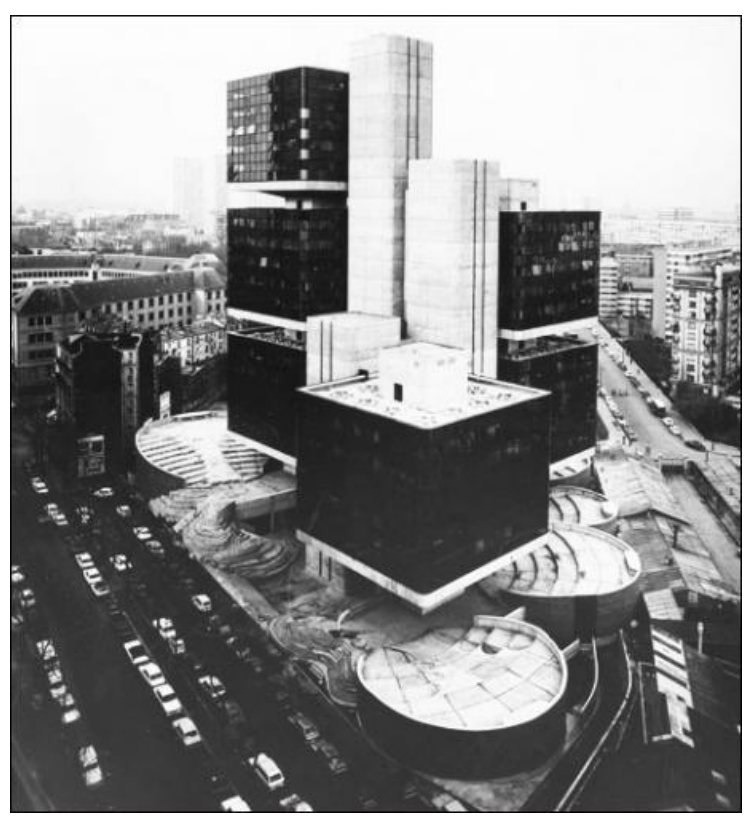
série de experiências, tanto de um modelo de planejamento que seria tipicamente francês quanto por modelos influenciados por experiências alemãs ou inglesas, há um retorno ao mais antigo arranjo de territórios universitários: 0 modelo urbano, concentrado em um único edifício situado em área urbana adensada, em meio à trama urbana (figura 10). Um modelo, portanto, essencialmente medieval, mas que incorpora algumas experiências do último século.

Fonte: Pierre Parat (1970-1973)

A diversidade de soluções possíveis no período pós-reforma também demonstra a atualidade da discussão sobre o tema. Revistas de arquitetura abordavam o projeto de territórios universitários, até em matérias de capa. Estilos se sobrepunham uns aos outros, sendo que algumas vezes os edifícios universitários e o planejamento desses territórios eram os melhores exemplares desses estilos. 0 novo brutalismo, por exemplo, tem entre seus principais exemplos alguns edifícios

diferenças acadêmicas em sua concepção. lbid., pgs. 225-246.

31 Destaca-se a proposta para Tolbiac, em 1972, que concentra todas as atividades para quase sete mil estudantes, em um edifício de vários pavimentos situado em lote urbano, de 5000 m2. lbid., pg. 265. 
universitários ${ }^{32}$. Verificam-se nesse estilo grandes edifícios com características escultóricas em concreto armado, que agrupavam em uma única grande massa construída todo o programa institucional. Outro arranjo estilístico, pelo menos quanto ao projeto urbanístico é sistema de redes, ou matemático. Nesse modelo o espaço é subdividido em uma espécie de grade, que direciona as possibilidades de crescimento das construções ${ }^{33}$.

Finalmente, alguns aspectos presentes em planejamento após os anos 70 merecem ser destacados. Da Alemanha, o estudo do planejamento universitário criou um refinamento do processo de planejamento, subdividindo-o em estágios como o planejamento geral (Leitplanung) e planejamento orientado para o uso (Bedafrsplanung). Arquitetos argumentam que o planejamento físico não deve se fundamentar na opinião do cliente direto, já que um professor de uma disciplina hoje tem opinião diferente de outro professor da disciplina amanhã. Da Inglaterra, o foco nas questões de circulação e conectividade entre os elementos individuais que compõem uma universidade conduziu a estudos muito detalhados, desenhados por meio de diagramas. Constata-se, portanto, uma experiência de estudar o problema de maneira muito detalhada ${ }^{34}$.

As incertezas econômicas depois da crise do petróleo (primeira metade dos anos 70 ) reduzem as realizações em construção de novos territórios universitários. Essa situação, somada à experiência descrita no parágrafo anterior, conduziu os planejadores para uma prática fundamentada nos conceitos de indeterminação e mudança. Indeterminação relaciona-se com a consciência de que uma edificação não poderá ser planejada integralmente, já que não é possível controlar as atividades que ali serão desenvolvidas. Mudança relaciona-se com a consciência que as atividades desenvolvidas nos espaços sofrerão alterações cada vez mais frequentes, sem a necessidade de uma eventual reforma. Essa abordagem diagramática oferece a possibilidade de planejar o espaço de forma modular, fundamentada em princípios gerais de crescimento e modificação. Portanto, pode-se afirmar que esse modelo aceita a crítica do planejamento integral dos territórios universitários e é uma alternativa ao "não-planejamento". Exemplos de novas universidades construídas de

\footnotetext{
32 Yale Art and Architecture, construída em 1963.

33 Ibid., pgs. 271-273.

34 Ibid., pg. 275.
} 
acordo com essas abordagens são encontrados em Loughborough e na Open University, em Milton Keynes, ambas na Inglaterra. Exemplos de rearranjos são a Universidade da Califórnia em Santa Cruz, com as moradias organizadas em edificações que se parecem com casas típicas da cidade. E, finalmente, o modelo francês de edificações dispostas como edificações comuns da cidade, sem a conformação de um território apartado, mas perfeitamente integrado com a cidade e, portanto, resgatando conceitos medievais ${ }^{35}$.

Ainda nos anos 70, atendendo tanto às demandas por maior democracia ressonâncias de 1968 - quanto à aplicação na prática de teorias acadêmicas desenvolvidas por sua equipe, deve ser citada a experiência de Christopher Alexander na Universidade de Oregon (figura 11). A partir das teorias definidas em seu título "The Timeless Way of Building" e de procedimentos descritos em seu manual "Uma Linguagem de Padrões" ${ }^{36}$, Alexander e equipe coordenaram o processo de planejamento da Universidade de Oregon como modelo reproduzível em outras comunidades que tenham similaridades (único proprietário e orçamento centralizado). Ao invés de entregar um plano diretor convencional ou um plano direcionado para o uso (como no modelo alemão) ou ainda um plano modular, a equipe substituiu esse

Figura 11: Universidade de Oregon (diagnóstico de 2014, ainda sob a orientação do sistema de Alexander).

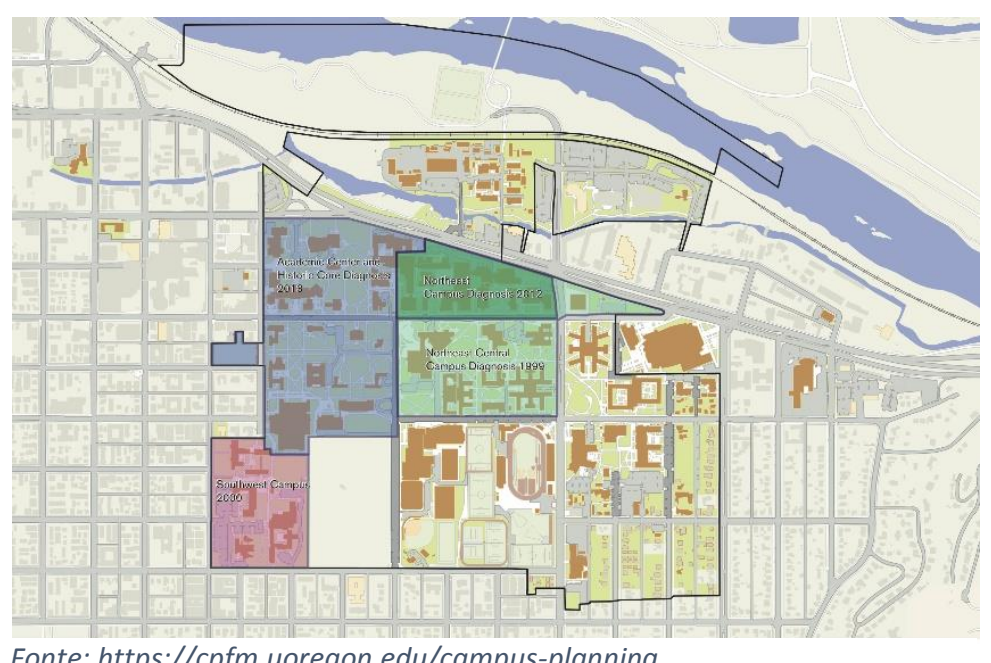

"produto" por um processo composto por seis princípios. São eles: princípio da ordem orgânica, princípio da participação, princípio do crescimento a pequenas doses, princípio dos padrões, princípio de diagnósticos e princípio de coordenação. O objetivo dessa metodologia é permitir a construção de

35 Ibid., pg. 278-280. Além da descrição de Muthesius, podemos observar, por exemplo, a Universidade de Paris 12 - Cretéil (1994), que confirma o novo paradigma.

36 O primeiro não foi traduzido para o português, enquanto o segundo possui uma tradução recente, lançada em 2013. A trilogia original se completa com o título "The Oregon Experiment", cuja versão utilizada neste trabalho é uma tradução espanhola. A ordem de lançamento dos títulos foi invertida, entre 1973 (The Oregon Experiment) e 1979 (The Timeless Way of Building). ALEXANDER (1978). Sobre as obras de Alexander, ver BATTAUS (2014). 
lugares mais humanos e orgânicos, resultando no modo atemporal de construir ${ }^{37}$. Essa metodologia teve grande repercussão, tanto nos meios de planejamento de territórios universitários como nos meios de planejamento de cidades ou parcelas de cidades. Os princípios participativos, por exemplo, foram incorporados em leis urbanísticas ${ }^{38}$. No Brasil, por exemplo, a Escola de Engenharia de São Carlos (EESC) compôs o "Grupo Alexander" em 1984, a partir de algumas experiências anteriores e culminada com a própria presença de Christopher Alexander na cidade. Este grupo tornou-se responsável por alguns projetos participativos institucionais no Campus I (figura 12) e conjuntos habitacionais na cidade de São Carlos ${ }^{39}$. Sobre essa experiência brasileira, é importante consultar o Relatório Técnico de Pós-Doutorado de Danila Battaus, que narra detalhadamente as experiências realizadas no Campus São Carlos, a partir de 1983 40. Dessas experiências resultaram a reforma de um laboratório, uma copa, jardins, a área de convivência do bloco B1 e circulações. O relativo sucesso de um projeto denominado "Projeto Pomar", de plantação de árvores frutíferas em áreas sem uso, levou a experiência para fora do Campus. É importante

Figura 12: Reforma da sala do Grupo Alexander em São Carlos.

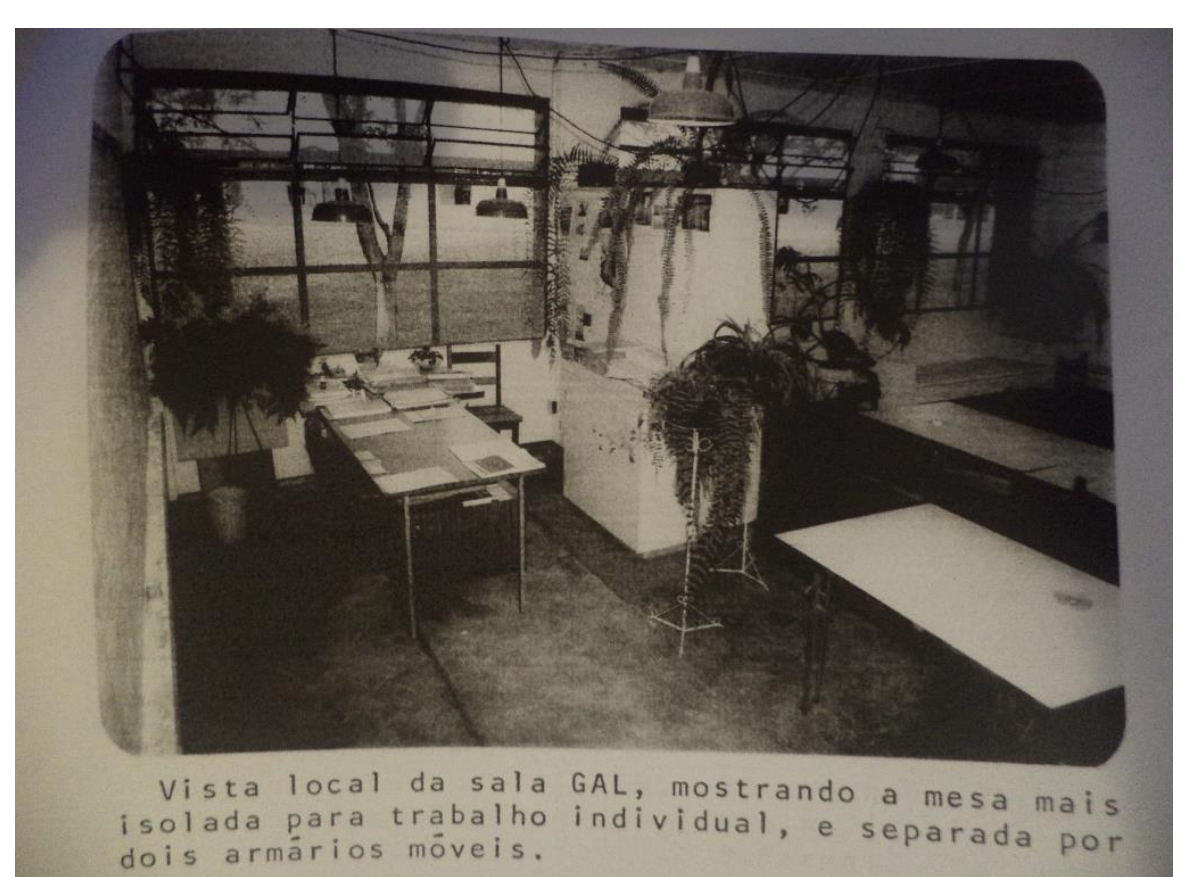

Fonte: EESC (1984), pg. 24.

37 ALEXANDER (1978), pg. 13.

38 Por exemplo no Estatuto das Cidades (Lei 10257/01).

39 BATTAUS (2004), pg. 30 e EESC (1984).

40 BATTAUS (2004), pgs. 207-210.

41 Idem. ressaltar que o Brasil dos anos 80 não possuía qualquer experiência em projetos participativos e que vivíamos em um período ditatorial, o que confere, segundo Battaus, um caráter audaz às atividades do Grupo Alexander ${ }^{41}$. 
O próprio Alexander e sua equipe ainda tiveram a oportunidade de utilizar seus princípios em outra localidade: Eishin Gakuan, parte do Higashino College, em Tóquio, Japão (entre 1985 e 2012). Nesse projeto suas ideias evoluíram e se sofisticaram a ponto de envolver, não só no projeto, mas também na construção física do objeto (o campus), aspectos ambientais, de participação social e de "sentimento humano". Trata-se de uma abordagem que parte dos princípios participativos mas envolve um compreensão holística do espaço, integralmente conectada com o meio-ambiente e com a dimensão humana compreendida de uma maneira mais íntima, psicológica, individualizada - sem exageros, quase ecumênica. A beleza dos espaços, seu impacto psicológico no indivíduo, é muito "importante" para Alexander, que identifica o progressivo abandono desse ideal no século $X X$. A frase que resume seu posicionamento mais recente pode ser a seguinte:

The central issue of architecture, and its central purpose, is to create those configurations and social situations, which provide encouragement and support for life-giving comfort and profound satisfaction - sometimes excitement - so that one experiences life as worth living. When this purpose is forgotten or abandoned, then indeed, there is no architecture to speak of. ${ }^{42}$

Nas últimas duas a três décadas, diversos aspectos têm ampliado as interações entre cidade e territórios universitários ao redor do globo. Enumeremos alguns: 1) pressão econômica para formação dos jovens no âmbito produtivo, ou seja, diretamente no mercado de trabalho, por meio de estágios, educação continuada, etc, fazendo com que haja interação entre o ensino dentro da universidade e fora dela; 2) pressão pública para ampliação do acesso ao ensino superior, transformando as universidades em espaços mais democráticos; 3) oferta de serviços pela universidade para o público geral, por exemplo, na área de saúde pública e cultura; 4) crescimento das parcerias entre universidade e empresa na área de pesquisa, compartilhando o tempo dos pesquisadores em ambos os lugares; 5) novas práticas arquitetônicas no desenvolvimento dos edifícios universitários, integrando-os com o entorno e tornandoos mais convidativos. Esses aspectos são trabalhados por Chapman, que não nega a tradição do campus as oasis, mas destaca o impacto que causam na vida cotidiana da universidade, potencialmente reforçando ou minando seus valores institucionais,

42 "O objetivo central da arquitetura, e seu propósito central, é criar aquelas configurações e situações sociais as quais promovam o encorajamento e suportem a oferta de conforto e profunda satisfação - algumas vezes até a excitação - para que uma pessoa experimente a vida integralmente. Quando esse propósito é esquecido ou abandonado, não há arquitetura sobre a qual se falar" (tradução livre). ALEXANDER (2012), pg.2. 
fator essencial em seu recorte territorial (Estados Unidos) ${ }^{43}$.

Aliás, é interessante perceber o que há de comum em alguns dos mais conhecidos textos recentes publicados nesse país. Há um entendimento que o espaço físico (construído e não construído) deve refletir os valores e a missão institucionais. Por exemplo, em decisões como construir um edifício de determinada maneira ou fechar um estacionamento de automóveis individuais há um reflexo desses valores e missão, que dizem respeito não apenas ao projetista contratado. Há, também, um objetivo de criar um "senso de lugar". Espaços convidativos, que evoquem boas memórias e reconhecimento. Edifícios ou arranjos urbanísticos que sejam perceptíveis e diferenciáveis dos demais. E há uma procura por espaços que permitam constantes mudanças institucionais, novos arranjos sociais e a adoção de novas tecnologias, tanto na arquitetura, urbanismo e paisagismo ${ }^{44}$.

\subsubsection{Campus, cidade universitária e territórios universitários}

Trata-se de uma discussão de fundo, que não é apenas etimológica, mas que guarda em seu bojo questões maiores. Afinal, como nos referirmos a este tipo de território: campus ou cidade universitária? A seguir acompanhamos o que afirmam os principais autores que escreveram sobre o tema.

Em sua obra seminal, Richard Dober (1963) não utilizava o termo "cidade universitária". Referia-se sempre aos territórios universitários como "campus", independentemente de sua localização na cidade ou no campo, da época de sua construção (ou planejamento), ou do nível (ou tipo) da instituição, se "university" ou "college" 45. Em seu título mais recente (2000), acrescenta significados ao termo "campus": construções e campos integrados em recintos verdes de agradável

43 CHAPMAN (2006).

44 COULSON, ROBERTS e TAYLOR (2011), pgs. 235-237; e também a introdução de CHAPMAN (2006), e o título de KENNEY, DUMONT e KENNEY (2005).

45 University são instituições que oferecem cursos superiores introdutórios ou profissionais, desenvolvem pesquisas e oferecem estudos pós-graduados. Os colleges, nos Estados Unidos, originalmente ofereciam apenas cursos introdutórios, apesar de atualmente a diferença se resumir ao nome tradicional da instituição, pois há colleges com as mesmas características que as universities, a fim de manter a "marca". No entanto, o surgimento da instituição college tinha a finalidade específica de abrigar estudantes durante seu tempo na cidade que sediava a universidade. Depois, passou a oferecer parte da formação, conceito ainda válido na Inglaterra. 
visualização, bem definidos fisicamente e com um senso específico de lugar e produtivos em encorajar fortuita e sinergicamente a interação entre os indivíduos que compartilham o uso desse lugar. Oferece como exemplos os centros de pesquisa, centros médicos, complexos produtivos de computação e informática, centros de arte performática, habitação para idosos e aposentados, complexos governamentais e escolas internatos.

Thomas Gaines (1991) preocupa-se principalmente com a qualidade do espaço, definindo com muita precisão o que entende por qualidade, mas sem dedicarse a definir o que significa "campus". Utiliza este termo tanto para colleges como para universities, porém reserva o uso da palavra para espaços efetivamente ocupados ou planejados e não para a "gleba" como um todo. Ou seja, sua concepção do que é um campus está diretamente ligada ao seu uso, ou seja, apenas ao acadêmico e ao seu acessório.

Stefan Muthesius (2000) explica detalhadamente a origem do termo "campus", surgida em Princeton no fim do século XVIII, com o objetivo de descrever o conceito de unidade buscada pelos colleges ou universities 46 . Primeiramente, 0 termo significaria a localização da instituição (sem qualquer diferenciação entre a localização no campo ou na cidade, a despeito da etimologia da palavra ${ }^{47}$ ). Com o tempo o termo ganhou um significado mais amplo, sem apartá-lo do que é a própria instituição. Para diferenciar o conceito de instituições com maior complexidade, tanto acadêmica como de serviços, Muthesius se apropriou do termo "multiversity". Com relação à experiência britânica, o autor informa que o termo campus foi tardiamente adotado e muitas vezes de maneira equivocada entendido como "universidade em um jardim". A concepção britânica do termo "campus" é mais ligada aos usos não acadêmicos, portanto ao contrário da concepção norte-americana, que dedica a centralidade do campus (e a convivência, notadamente) aos espaços educacionais ${ }^{48}$. Por fim, ao detalhar a experiência continental europeia, o autor não diferencia a universidade em

46 Muthesius rapidamente explica o uso que faz do termo college, que pode ser entendido como o complexo de facilidades que o corpo discente faz uso durante seu período matriculado na educação superior (como habitação, serviço de alimentação, etc), sem necessariamente incluir as edificações de ensino ou de pesquisa.

47 Campus é uma palavra de origem latina que significa campo.

48 Mais à frente será visto que esta diferenciação histórica está superada, pois novos empreendimentos em ambos os lados do Atlântico possuem características comuns, incluindo a região continental europeia. 
si do lugar o qual ocupa, além de citar o caso de algumas instituições em cidades pequenas, cuja existência e cotidiano se confunde ao da própria cidade. Somente irá utilizar o termo "cidade universitária" quando trata das universidades ao redor do mundo que se classificam como "o orgulho" da nação, ou instituição cultural nacional, dentro do contexto modernista e de uma implantação devidamente coordenada (em um período delimitado). Mas, mesmo assim, ainda utiliza o termo "campus" para referir-se a elas, como se fosse um tipo muito particular desta terminologia.

Finalmente, Paul V. Turner (1984) define o espírito do termo "campus" logo no prefácio, ao citar o termo "academical village", proferido por Thomas Jefferson, que desenhou o campus da Universidade de Virgínia, e que daria origem à história do planejamento de campus universitário. Este termo "sumariza o tratado básico da educação superior norte-americana do período colonial ao século $\mathrm{XX}$ : a concepção de colleges e universidades como comunidades em si mesmas, em efeito, como cidades em microcosmo". Portanto o termo "campus" teria esse significado que representa o próprio conceito de universidade para a cultura norte-americana, e por esse motivo tem tanta influência na própria literatura. Turner é quem nos informa que a primeira vez que o termo "campus" foi utilizado no contexto norte-americano, em 1784, na ocasião da fundação da Nassau Hall, em Princeton. É virtualmente impossível pesquisar o tema sem plena consciência desta tradição e influência. Ainda que a história recente traga uma multiplicidade de possibilidades e que as fases anteriores da história das universidades não estejam ligadas especificamente a um território apartado da cidade, por mais de um século foi construída uma história de planejamento e realizações. Turner recorta seu estudo histórico no espaço geográfico de seu país por esse motivo. Mesmo autores mais recentes, como Coulson, Roberts e Taylor (2011) ainda utilizam quase metade de seus exemplos contemporâneos provenientes daquele país.

A universidade brasileira, aparecida tardiamente (décadas de 1920 e 1930), pela reunião de instituições isoladas pré-existentes, surge influenciada pelo modelo organizacional alemão: a universidade humboltdiana, que não desvincula pesquisa e ensino. A maioria dos exemplos que a literatura registra não indica a existência de "colleges", no sentido de permanência dos estudantes fora do horário acadêmico, portanto as instituições nacionais somente possuíam edifícios ligados às atividades acadêmicas - e a exceção será justamente o modelo que abordaremos, ainda que na 
origem seu público-alvo não seja composto por estudantes de nível superior.

As primeiras tentativas de construção de cidades universitárias, que datam dos anos 20 e 30 do século XX, têm origens europeias: seja o modelo beauX-arts de Alfred Agache; o modelo monumental art-decó de Marcello Piacentini (idem, 1930) ou o modelo modernista de Le Corbusier, que projetaram propostas para a Universidade do Brasil, no Rio de Janeiro, em 1930. Segundo Charle e Verger e também Stefan Muthesius, essas propostas poderiam ser classificadas como as instituições culturais nacionais, cabendo o termo "cidade universitária", como de fato os autores fizeram. Uma leitura alternativa dessa diferenciação é dada por Carlos Roberto Monteiro de Andrade, no prefácio de Buffa e Pinto (2009), considerando que o ideal destes planejadores era a construção de uma universidade vinculada ao espírito urbano e não ao afastamento idílico típico dos "campi" norte-americanos, como Dober (2000) nos apresentou. Os autores do mesmo livro têm ainda uma terceira leitura: cidade universitária seria uma região autônoma, regida pelas regras acadêmicas, enquanto o campus dependeria da infraestrutura da cidade que se avizinha. Nesse sentido, raríssimos seriam os casos de cidades universitárias, e os exemplos aqui citados não deveriam receber tal nomenclatura.

Neste trabalho será feita uma distinção. A concepção norte-americana da palavra campus, ou seja, qualquer espaço ocupado por uma instituição educacional de nível superior, é entendida como um "território universitário". Portanto esse termo aparecerá com bastante frequência, quando nos referirmos genericamente aos espaços com essas características, em substituição ao termo "campus". Este último e "cidade universitária" somente aparecerão quando nos referirmos a um caso específico cujo nome oficial contenha os termos, por exemplo: Cidade Universitária Armando Salles de Oliveira (CUASO), que pertence à USP ou Campus Luiz de Queiroz, que também pertence à USP. Concordamos com a definição mais ampla, oferecida por Chapman, que essa categoria de território (ele utiliza a palavra "place", ou "lugar") representa "mais que a geografia ou definições físicas, mas também a soma de experiências, atividades, eventos e memórias que ocorrem dentro de suas fronteiras" 49.

Observamos, ainda, que até o começo da década de 50 , no Brasil não se

49 CHAPMAN (2006). 
utilizava o termo "campus". Ainda que apareça pontualmente no livro de Ernesto de Souza Campos, especialmente quando apresenta registros de professores que estiveram em intercâmbios nos Estados Unidos. Ele mesmo se equivoca e no livro "Cidade Universitária da Universidade de São Paulo" usa a expressão "campus da cidade universitária", que aparece em documentos oficiais dos anos 50, como registrado em um documento da Universidade do Brasil ${ }^{50}$.

Além da definição de território, outras definições aparecem durante o decorrer do texto e precisam ser melhor apresentadas. Tratam-se de formulações de categorias mais gerais: território, lugar e paisagem.

O território é o espaço geográfico, que Milton Santos define como uma mediação entre o mundo e a sociedade ${ }^{51}$, ou um recorte geográfico que pode ser assumido como um conceito indispensável para entender o funcionamento do mundo tal como ele é hoje. Esse conceito de território pode ser organizado de maneira horizontal, que reúne vizinhos contíguos; e vertical, que é formado por pontos distantes uns dos outros, reunidos das mais diversas formas e processos sociais, ou ainda "em rede". Quando nos referimos aos territórios universitários sem qualquer delimitação geográfica explícita ou recorte temporal, significa que utilizamos exatamente essa concepção de território em rede, enquanto categoria do espaço geográfico completamente envolvida no mundo globalizado contemporâneo.

No mesmo texto, Milton Santos define o lugar como o território palpável no qual as ações globalizantes se territorializam. É o território no qual as ações cotidianas acontecem e onde a sociabilidade se desenvolve. Nesse sentido, o lugar ganha uma característica mais íntima, que remete à descrição de Yi Fu Tuan, que caracteriza lugar como o espaço que adquire definição e significado ${ }^{52}$. Utilizando como exemplo o lar, Yi Fu Tuan determina a afeição ou a intimidade com um espaço como condição para um sentido elementar de lugar. Anne Buttimer amplia o lugar para o conceito de horizonte de alcance: enquanto o primeiro retrata a experiência vivida no espaço, o segundo inclui as perspectivas fora desse espaço experimentado. Certamente é uma compreensão fenomenológica do termo, considerando que para cada indivíduo há

\footnotetext{
50 CAMPOS (1954).

51 SANTOS (1994).

52 TUAN (1983).
} 
uma diferente compreensão de significado do lugar.

Lugar é uma pausa no movimento, uma pausa que permita que uma localidade se torne um centro de valor conhecido. Os territórios universitários tornam-se lugares para a comunidade acadêmica a partir do momento em que seus indivíduos ali convivem, desenvolvem experiências íntimas ou de sociabilidade, ou mesmo quando essas experiências se tornam possíveis. Uma localidade torna-se um lugar quando é um espaço reconhecível pela sua comunidade. Ao nos referirmos aos territórios universitários como lugar, destacamos essa presença humana e a existência de um cotidiano real ou possível, extrapolando as meras condições físicas do território. Inserindo nessa dimensão teórica a questão da prática, temos a posição adotada por Chapman, como visto anteriormente.

O conceito contemporâneo de paisagem descende da ideia de um recorte do território observável à luz de sua existência no campo da cultura e da história. Ou seja, um recorte que não é aleatório, mas abriga certa unidade sob a ótica da cultura e da história. Mas o conceito contemporâneo parte dessa definição para incluir o aspecto de gestão desses recortes, com o objetivo de preservá-lo e oferecê-lo como um direito para toda a sociedade ${ }^{53}$. É nesse sentido que adotaremos o conceito de paisagem, extrapolando o nível da simples constatação e prevendo a sua gestão ou manejo.

Dessa maneira, pretendemos utilizar esses conceitos para entender a construção da categoria "territórios universitários" enquanto lugar, incluindo suas relações com a cidade e a própria instituição. No caso específico aqui abordado, não apenas reconhecer esses processos materializados no Campus Pirassununga e a sua relação com a cidade, mas se há um modelo de território universitário em ambientes rurais.

${ }^{53}$ GÓMEZ MENDOZA (2008), págs. 11-56. 


\subsection{Os antecedentes históricos da universidade brasileira}

1.2.1 Colônia e independência: a América Latina e a experiência tardia brasileira

A história das universidades no Brasil se inicia em períodos muito recentes. Por uma série de fatores políticos, de disputas regionais, o país não fundou uma universidade sequer até 1909, quando uma iniciativa local proporcionou a fundação de uma modesta universidade em Manaus (que perdurou até 1926), ou então até 1912, se considerarmos apenas instituições ainda ativas, quando houve a fundação de uma instituição em Curitiba que deu origem à futura Universidade Federal do Paraná (UFPR) ${ }^{54}$.

Em compensação, a América Latina faz parte da história das universidades desde 1538, com a fundação da posteriormente fechada Real y Pontificia Universidad San Tomás de Aquino, em Santo Domingo, atual República Dominicana. Em 1548, houve a fundação da Universidad Nacional Mayor de San Marcos 55, em Lima, no

Figura 13: Brasão da Universidad Nacional Mayor de San Marcos, a decana das Américas.

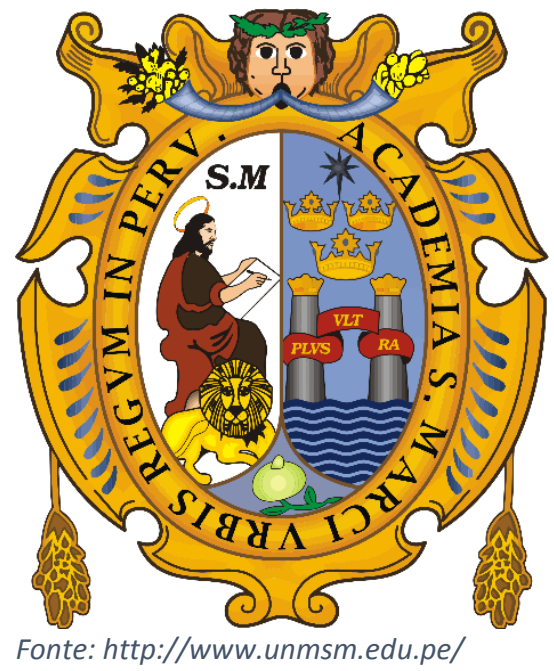

Peru, originalmente conhecida como Real y Pontificia Universidad de la Ciudad de los Reyes de Lima e a mais antiga em funcionamento no continente. Em 1551 foi fundada a Real y Pontificia Universidad de México, cuja herdeira é a Universidade Nacional Autónoma de México ${ }^{56}$, na Cidade do México, ainda que oficialmente não sejam a mesma instituição. Outras instituições foram fundadas no período colonial e mantêm-se abertas: a Universidad de Córdoba, na cidade de mesmo nome na Argentina, fundada em 1613, atual Universidad Nacional de Córdoba 57; a Real y Pontificia

54 RODRIGUES (2001), pg. 79 e http://www.ufpr.br/portalufpr/historico-2/, acessado em 23/10/2016.

55 De importância histórica sem par no país. Sobre a história da universidade, ver o sítio na rede em: http://www.unmsm.edu.pe/home/inicio/historia

56 Mais adiante a sua história será novamente abordada. Mais detalhes no sítio oficial da instituição na rede: http://www.unam.mx/acercaunam/es/unam_tiempo/unam/antecedentes.html

57 A vasta história desta universidade guarda um capítulo de grande importância, a Reforma de 1918, sobre a qual trataremos mais adiante. O sítio da universidade na rede pode ser acessado por: http://www.unc.edu.ar/institucional/historia/origenes 
Universidad de San Francisco Xavier, em Sucre, na Bolívia, fundada em 1622, atual Universidad San Francisco Xavier de Chiquisaca 58; a Real y Pontificia Universidad de San Gregorio Magno, no Equador, em Quito, também em 1622, cuja sucessora é a Universidad Central del Ecuador 59; a Real Universidad de San Carlos Borromeo, fundada na Cidade de Guatemala, em 1676, atual Universidad San Carlos de Guatemala 60; a Real Universidad San Antonio Abad, fundada em Cusco, no Peru, em 1692, atual Universidad Nacional San Antonio Abad del Cusco ou Mama Llaqtap San Antonio Abad Yachay Sunturnin 61; a Universidad San Jeronimo, fundada em Havana, Cuba, em 1721, atual Universidad de La Habana; a Real y Pontificia Universidad de Caracas, fundada na cidade de mesmo nome em 1722, atual Universidad Central de Venezuela 62; e, finalmente, a Real y Literaria Universidad de Guadalajara, em 1792, na cidade de mesmo nome, no México, atualmente apenas Universidad de Guadalajara ${ }^{63}$.

Todas essas instituições foram fundadas em meio às cidades e se assemelhavam às instituições medievais europeias, tanto nos aspectos organizacionais e acadêmicos, como em sua distribuição espacial. Obviamente sua importância local as tornou centros de difusão da cultura da metrópole e formadoras dos quadros técnicos e administrativos das colônias. Ao longo do tempo, tornaram-se lugares de reflexão que proporcionaram apoio aos processos de independência dos países da América Espanhola, devido a uma certa frouxidão com a qual a metrópole

58 Nesta universidade foi planejada e conspirada a independência da Bolívia. Sobre sua história, ver o site oficial da instituição em: http://www.usfx.info/edif/index.php?id=0\&pag=163\&ex=yes.

59 Surgida a partir de instituições pré-existentes, depois fundida com a Universidad San Tomás de Aquino, em 1789, para dar origem a atual em 1826. Sobre sua história consultamos um texto baseado em fontes oficiais, http://ecuadoruniversitario.com/opinion/documentos/breve-resenahistorica-de-la-universidad-central-que-hoy-cumple-186-anos/

60 A única universidade pública da Guatemala, atualmente espalhada por todo o país. Sobre sua história, consultar o sítio oficial da instituição: http://www.usac.edu.gt/historiaUSAC.php.

61 O sítio oficial da instituição não apresenta muitos detalhes históricos. O endereço disponível é: http://www.unsaac.edu.pe/universidad/resenia.php

62 No final da fase real e pontifícia o controle da metrópole era frouxo e por esse motivo foi a partir dessa universidade que surgiram os intelectuais pró-independência da América Espanhola, como Andrés Bello. Sobre sua história, o sítio da universidade pode ser acessado em: http://www.ucv.ve/sobre-la-ucv/resena-historica.html

63 A primeira universidade latino-americana a aceitar mulheres e alunos de qualquer credo, além de ter sido a primeira a tornar-se autônoma da influência papal ou real. Sobre sua história, o sítio da universidade é: http://www.udg.mx/es/historia. 
controlava o sistema universitário colonial ${ }^{64}$. No entanto, ressalte-se que no caso da Real y Pontificia Universidad do Mexico essa constatação não é possível, pelo seu caráter historicamente conservador ${ }^{65}$. Também é importante reforçar que essas instituições, a despeito de sua importância regional, não trouxeram novidades significativas no plano pedagógico ou físico - apenas copiavam o modelo metropolitano.

Na primeira metade do século XIX os países da América Latina conquistaram suas independências. A necessidade de uma construção da identidade nacional conduziria os governos a criar instituições com o propósito de serem depositárias da cultura local, formadoras de quadros intelectuais e catalisadoras das diversidades que compunham esses países, alguns deles majoritariamente compostos por populações indígenas, sem identidade com a elite branca dirigente. Nesse aspecto, o Brasil não acompanhou a América Espanhola, já que não possuía uma instituição com essas características, mesmo fora do âmbito universitário.

Na Argentina, esse movimento culminou com a fundação da Universidad de Buenos Aires, em 1821, mas apenas depois de 1885 essa instituição passa a ser considerada a universidade de caráter nacional, quando a Universidad de Córdoba passa ao controle da província ${ }^{66}$. Na Bolívia é fundada a Universidad Mayor de San Andrés, em 1830, na cidade de La Paz ${ }^{67}$. No Chile, é fundada a Universidad de Chile em $1842^{68}$. No Uruguai a Universidad de la Republica é fundada em $1848^{69}$. No Peru, a Universidad Mayor de San Marcos assumiu esse papel, porém adicionou o termo

64 CHARLE e VERGER (1996), pg. 90.

65 Como instituição poderosa no período, a Universidade do México inicialmente apoiou o regime monárquico, mudando de lado apenas quando o movimento republicano de independência era inevitável, junto com a elite da Nova Espanha, no Plano de Iguala de 1821, que preservava os poderes estabelecidos da elite local. Futuramente, esse elitismo conduziria ao fechamento da universidade. AGUIRRE SALVADOR (2011).

66 Sobre sua história, é possível consultar o sítio da universidade na rede no seguinte endereço: http://www.uba.ar/historia/contenidos.php?id=2\&s=19

67 O caráter nacional desta universidade a acompanha desde sua fundação, mesmo considerando a pré-existência da Universidade San Francisco Xavier de Chiquisaca, ou seja, um caso parecido com o argentino. Sobre sua história, é possível consultar o sítio da universidade na rede no seguinte endereço: http://www.umsa.bo/documents/10204/16823/HistoriaUMSA.pdf/516046c6-92de-4764a98c-e252139989e6

68 Sobre sua história, é possível consultar o sítio da universidade na rede no seguinte endereço: http://www.uchile.cl/portal/presentacion/historia/resena-historica/4727/una-mirada-a-la-historia

69 Sobre sua história, é possível consultar o sítio da universidade na rede no seguinte endereço: http://www.universidad.edu.uy/renderPage/index/pageld/98\#heading_761 
"nacional" ao seu nome apenas em 1946.

Na Colômbia, Venezuela e Equador, a experiência universitária se iniciaria com a Universidad Central de la Republica, de vida efêmera como a própria Grã-Colômbia (1819-1830). Dos três países, a Colômbia demoraria alguns anos para se firmar como unidade institucional, portanto apenas em 1867 a Universidad Nacional de Colombia seria fundada, inicialmente em Bogotá ${ }^{70}$. No Equador, a pré-existente Real Universidad San Tomás Aquino daria origem à Universidad Central del Ecuador, já em 1826, ainda no período da Grã-Colômbia. Na Venezuela, a Real y Pontificia Universidad de Caracas assumiria o papel de instituição nacional, transformando-se em Universidad Central de Venezuela em 1827, com estatuto novo redigido com a participação de Simón Bolívar. No Paraguai apenas em 1889 a Universidad Nacional de Asunción seria fundada, principalmente por causa dos efeitos da derrota na Guerra do Paraguai ${ }^{71}$.

Em 1918, manifestações estudantis na Universidad de Cordoba deram origem a "Reforma de 1918", que teve início na Argentina e se espalhou pelo subcontinente. É curioso notar que manifestações desse tipo, em outro contexto, se repetem cinquenta anos depois, no resto do mundo e no Brasil. As demandas eram por participação estudantil e democracia no sistema de educação superior, com a superação do modelo de cátedras e a autonomia tanto institucional como acadêmica, além da inclusão da pesquisa entre as funções da universidade (que, lembramos, não era relevante no modelo antigo) e do seu compromisso com a sociedade. Na pauta, a grande reivindicação era o compartilhamento da governança com a participação estudantil 72 .

A universidade reformada teve grande importância nas décadas de 1930 a 1960, servindo efetivamente como as instituições principais de formação e cultura nos países. Também cresceram consideravelmente, inaugurando cursos e ampliando vagas, incluindo classes antes excluídas da possibilidade de educação de nível superior. No mesmo período verifica-se o crescimento da influência da universidade

70 Desde os anos 30 a universidade conta com atividades em outras cidades. Sobre sua história, ver o sítio da universidade na rede em: http://unal.edu.co/la-universidad/historia/

71 O sítio da universidade da web apresenta uma cronologia resumida: http://www.una.py/images/stories/Universidad/Rese\%C3\%B1aHistorica/CRONOLOGIA_UNA_03.0 6.2014.pdf.

72 RIBEIRO (1968), pg.112. 
norte-americana sobre suas coirmãs do sul. Esses dois fatores proporcionaram um movimento para o planejamento e construção de novas áreas para abrigar as universidades nacionais, denominadas invariavelmente de "cidades universitárias". Em comum, algumas características se observam: grande defasagem entre a idealização (geralmente entre 1900 e 1920) e a realização (entre 1943 e meados dos anos 60); todas foram implantadas em locais suburbanos, mas muito próximos da cidade; ocupam áreas relativamente grandes, que poderiam comportar grande crescimento, de acordo com uma visão desenvolvimentista típica do período; adotaram planos modernistas, mesma inspiração para os primeiros edifícios.

A Cidade Universitária de Córdoba foi construída apenas nos anos 60, mas sua realização era planejada desde 1909. A Cidade Universitária de Buenos Aires foi iniciada também nos anos 60 , com planos de 1958, sendo que este foi inspirado em um plano de Le Corbusier e arquitetos locais de 1938. Até hoje conta com pouquíssimos edifícios e sua implantação integral é objeto de muitas discussões. No local onde há fundações de dois prédios existem, respectivamente, um

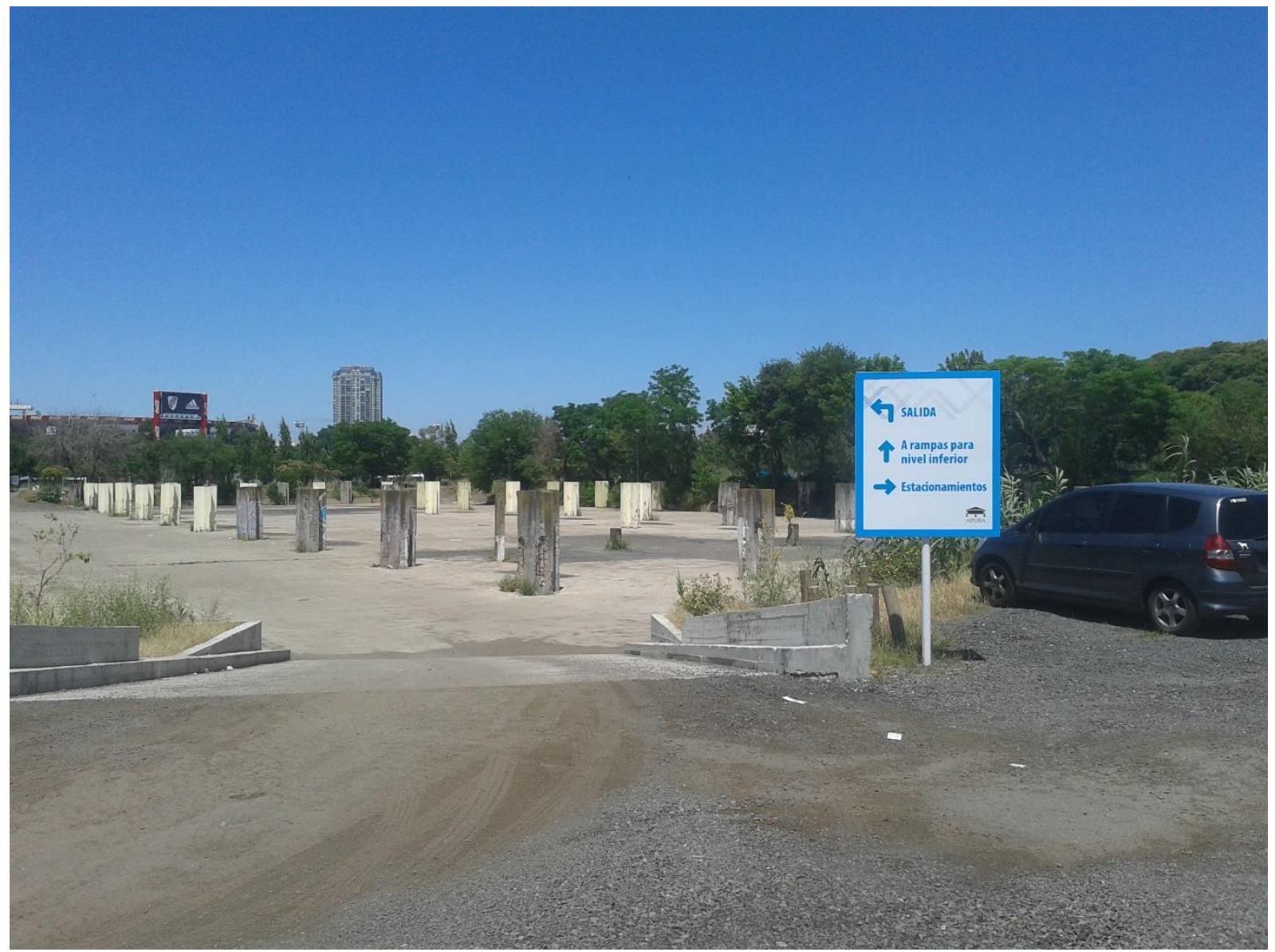


estacionamento e um bosque ocupado por estudantes (figura 14).

A Cidade Universitária de Lima teve ocupação iniciada em 1956, mesmo ano de seu plano urbanístico, mas sua realização também foi planejada desde a primeira década do século XX. Ao longo dos anos sua realização não acompanhou o plano inicial, tornando-se muito mais densa e com distribuição claramente menos organizada. No entanto, há autores que sustentam a sua importância e a incluem entre as grandes realizações desse período ${ }^{73}$.

A Universidad Nacional de Asunción também está abrigada em um território delimitado, com as mesmas características dos demais exemplos apresentados nessa seção. No entanto não recebe o nome de "cidade universitária".

Os exemplos que consideramos mais significativos, realizados no período, são as cidades universitárias de Caracas, México, Bogotá e Concepción (Chile).

Figura 15: Universidade Nacional Autônoma do México.

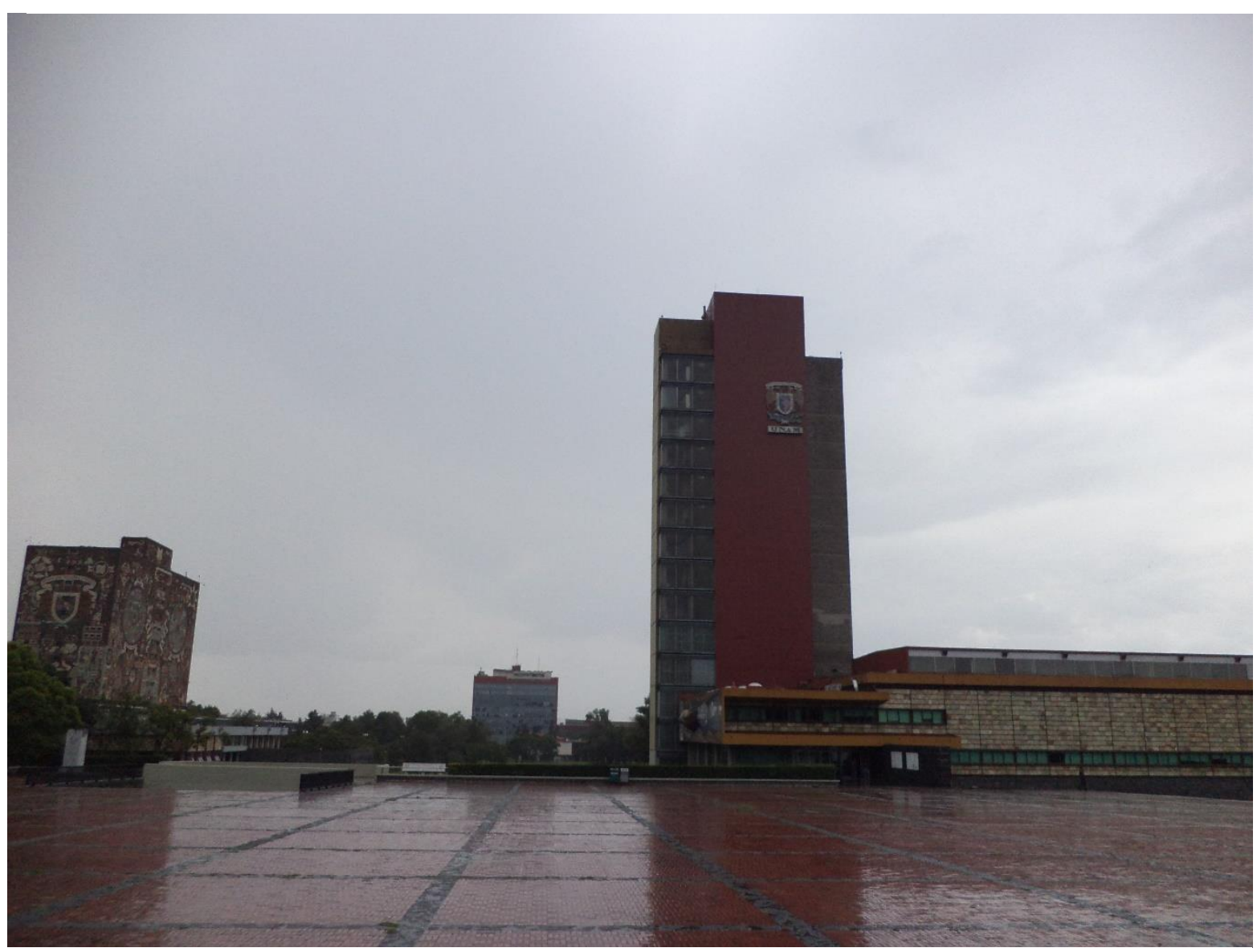

Fonte: autoria própria.

73 BRAVO (2007). 
A Cidade Universitária de Caracas foi planejada em 1943 por uma equipe comandada pelo arquiteto Carlos Raul Villanueva. O projeto das edificações também foi integralmente realizado por essa equipe. O lote é uma área então suburbana, a leste da cidade, facilmente acessível por avenidas expressas. Duas características se destacam nesse projeto: a organização tipicamente modernista do espaço, com implantação de edifícios com tecnologias pré-moldadas (em vários níveis) e a proposta de tornar a universidade um verdadeiro mostruário de arte moderna, distribuídas tanto pelas áreas "urbanas" como pelos edifícios e suas fachadas.

Situação quase idêntica a Caracas é a Cidade Universitária da UNAM, ao sul da cidade do México, em lote igualmente suburbano - que com o crescimento da cidade tornou-se totalmente integrado à mesma cidade. As características modernistas do projeto (1950-1953) também predominam, tanto no arranjo urbanístico como no projeto dos edifícios, cujos autores seguiram rigorosamente o estilo preconizado. Grande parte dos edifícios dispõe-se em lâminas, compridas e estreitas, bastante afastadas dos prédios vizinhos, para maximizar as melhores condições ambientais (vento, iluminação, etc). Essa opção projetual não era inovadora, mas a partir desse projeto apareceria com frequência. O maior destaque são as obras de arte espalhadas pelas praças e prédios (mais de 800), tornando a Cidade Universitária da UNAM um museu a céu aberto, muito representativo da arte e cultura mexicanas (figura 15).

Também é similar a história da Cidade Universitária de Bogotá, da Universidade Nacional da Colômbia. A instituição é refundada no ano de 1935, reunindo diversas faculdades isoladas e assumindo um caráter menos elitista. O plano físico foi desenvolvido em conjunto com o projeto pedagógico - aquele pelo arquiteto Leopoldo Rother e este pelo pedagogo Fritz Karsen, ambos alemães. Uma parte dos edifícios também foi projetada por Rother. A distribuição dos edifícios segue um padrão elíptico, que coincide com o diagrama pedagógico. Assim como em Caracas, a área estava situada em um subúrbio facilmente acessível a partir do centro da cidade (hoje é uma região considerada central). Apesar da distribuição simétrica e da composição referenciada no modelo clássico de quadrângulos, a arquitetura é tipicamente modernista (1937-1945).

Finalmente, a Cidade Universitária de Concepción (Chile), da Universidade de Concepción, foi também planejada de maneira integral. O que a difere e a destaca é 
que uma sequência de planos foram realizados, porém resguardando algumas características que permanecem desde o primeiro plano, de Karl Brunner, urbanista austríaco, desenhado em 1931. Brunner estava no Chile para realizar uma série de atividades profissionais em Santiago e o reitor da Universidade à época o convidou para realizar o plano do campus, considerando a experiência prévia do urbanista com relação ao tema. O plano estabelecia a implantação dos prédios principais no centro da gleba, conectados a áreas de convivência, enquanto os edifícios destinados às formações profissionais ficariam nas periferias (figura 16), e as vias urbanas circundando a "Cidade Universitária de Concepción".

Figura 16: Universidade de Concepción, praça central com os prédios principais ao redor, ideia remanescente do plano de Karl Brunner.

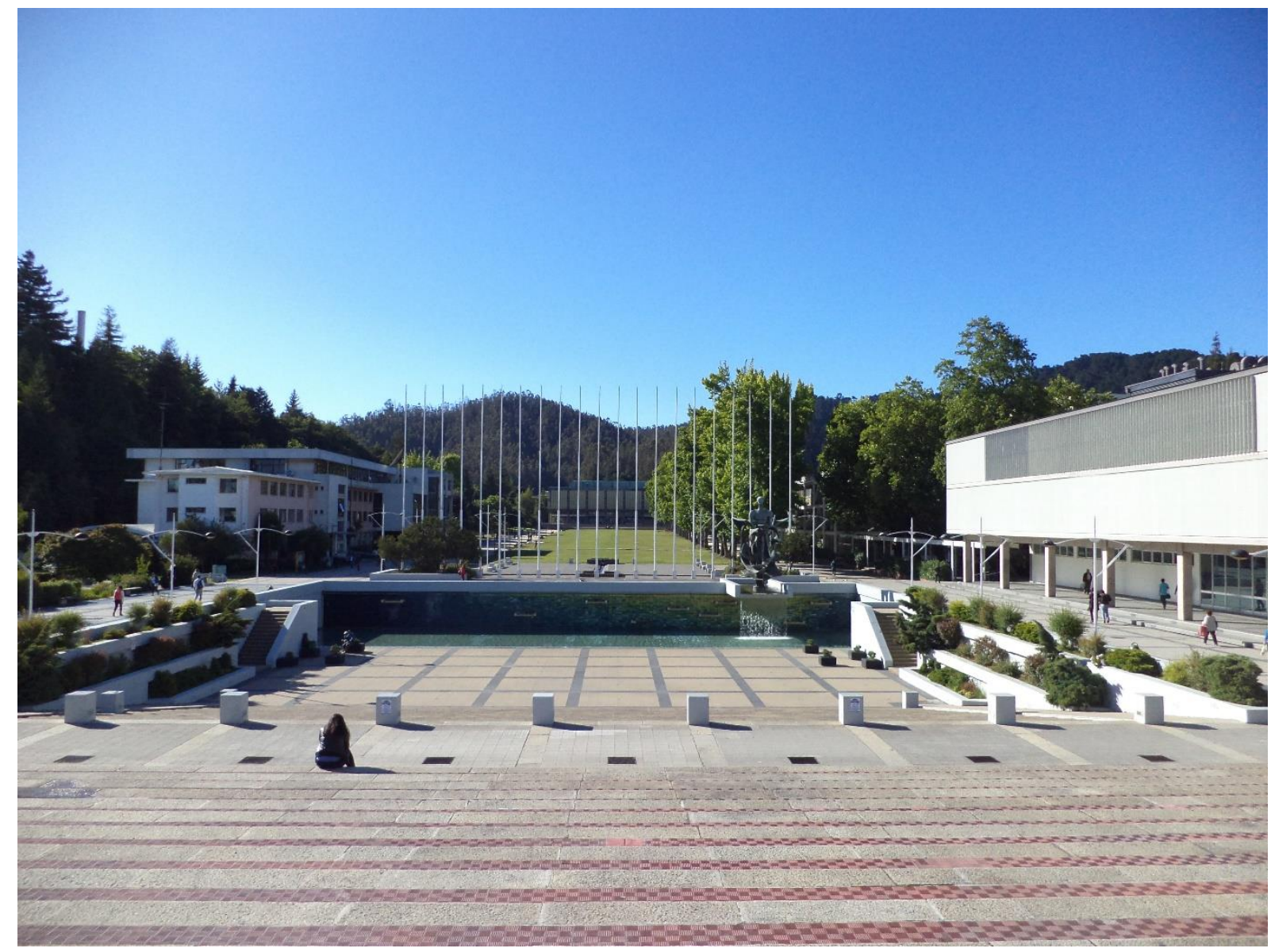

Fonte: autoria própria.

As intervenções posteriores, até o plano de 1966, foram realizadas de acordo com esse plano e o sistema continuou funcionando perfeitamente até os anos 1970. O exemplo de Concepción tornou-se um modelo pela sua grande difusão no Chile e no exterior, tanto pela novidade que era a construção de uma "Cidade Universitária", 
quanto pela relevância do trabalho de Brunner no Chile ${ }^{74}$.

Outros planos foram realizados em 1958 e 1966 (este último após um terremoto devastador). Em todos planos destacam-se os percursos na escala do pedestre e a profusão de jardins, resultando no que os urbanistas locais denominam "universidadeparque" ${ }^{75}$. Com relação à arquitetura, desde 1934 os edifícios são projetados de acordo com as características gerais do movimento moderno.

Diferente dos demais exemplos, essa é uma universidade privada e não está localizada em uma capital. Houve menor expansão física e interferência política. Também não é a instituição de caráter cultural nacional, ainda que em termos urbanísticos seja a principal realização chilena até a presente data. A Universidade de Concepción não estava integrada no processo de reforma dos anos 60 , que dividia o sistema universitário do país em universidades centrais e regionais, restando às últimas apenas departamentos de faculdades profissionais ou representações de serviços técnicos ${ }^{76}$. Por esse motivo o plano de 1966 é integral e sua organização institucional ainda se reflete na organização espacial.

\subsubsection{A educação superior no Brasil}

Este texto se embasa em alguns autores que relacionam o período inicial da universidade brasileira e o espaço que essas instituições ocupavam. Apesar de seu foco no projeto modernista, Luiz Augusto Fernandes Rodrigues (2001) realizou uma vasta pesquisa que fundamentou seu texto de embasamento histórico, preliminar à tese. Os professores Gelson Pinto e Esther Buffa (2009) são autores de um livro que analisa quatro casos significativos de territórios universitários, além de uma breve introdução histórica. Neyde Cabral (2004) é autora de uma tese sobre a evolução do espaço físico da Universidade de São Paulo, onde apresenta farta documentação primária. Florestan Fernandes e Darcy Ribeiro escreveram livros nos quais refletem sobre o papel da universidade brasileira na sociedade, respectivamente "Universidade

\footnotetext{
74 MOLINA (2015), pg. 108.

75 MOLINA (1994).

76 RIBEIRO (1968), pg.128.
} 
Brasileira: Reforma ou Revolução?", escrito em 1975 e "A Universidade Necessária”, organizado coincidentemente em maio de 1968, mês das rebeliões estudantis. Nesses textos, fazem comentários sobre as instalações físicas da universidade. Antes, ainda em 1954, o prof. Ernesto de Souza Campos redige um texto comemorativo à efeméride de vinte anos de fundação da Universidade de São Paulo, com farta documentação e conhecimento de causa, já que esteve presente na maior parte das comissões de implantação (e também participou da comissão da Universidade do Brasil em 1936).

Ao contrário das colônias espanholas, a educação superior nas colônias portuguesas não incluía a formação superior ou instituições para a educação da elite. Os ricos enviavam seus filhos para a Europa, enquanto as instituições religiosas se incumbiam de educar as demais classes. A Companhia de Jesus, instituída em 1534, no entendimento dos colonizadores, teve grande papel civilizatório no período em que esteve atuando na colônia, até sua expulsão em 1759. Fundaram instituições com o nome de "Colégios", que tinham o papel preponderante de impingir uma cultura que substituísse os saberes tradicionais do povo gentio, bem como limitar as influências advindas das invasões francesas e holandesas. A experiência é bem precoce: em 1549 os jesuítas desembarcaram na colônia e desde 1572 já havia cursos de Artes e Teologia na Bahia. Mas esse papel educacional não se compara sequer à universidade medieval e, portanto, não pode ser considerado como ensino superior. No entanto, há autores que dão grande importância a essa experiência, colocando-a na base da formação de uma cultura nacional vinculada à europeia, ibérica, em moldes humanísticos e literários clássicos, sem compromissos técnico-científicos ${ }^{77}$. Ou, melhor ainda, uma pura e simples transferência transatlântica de uma cultura universalista, prioritariamente religiosa e desvinculada das realidades regionais. Essas experiências poderiam desembocar na primeira universidade brasileira, mas a expulsão dos jesuítas impediu esse provável acontecimento. O resultado foi a formação muito restrita de jovens brasileiros: enquanto na América espanhola se formaram mais de 150.000 graduados, no Brasil colonial contam-se apenas 2.500 graduados por Coimbra ${ }^{78}$.

\footnotetext{
77 RODRIGUES (2001), pg. 70 e CAMPOS (1954), pg.15.

78 RIBEIRO (1968), pg. 78.
} 
Em 1759, quando houve a expulsão dos jesuítas, desenvolvem-se no Brasil novos ciclos econômicos, estabelece-se uma incipiente rede urbana e aporta - ainda que em pequena escala - uma influência da modernização iluminista pombalina. Essa conjuntura indicava a superação do modelo universalista e religioso que os jesuítas tentavam implantar. Mas apenas com a chegada da família real portuguesa ao Rio de Janeiro é que ações seriam efetivamente tomadas para a fundação do ensino superior no Brasil. Em 1808 finalmente decreta-se a abertura de cursos de medicina na Bahia e no Rio de Janeiro e em 1810 o curso de engenharia também no Rio de Janeiro. Em 1827, já no primeiro período imperial, é decretada a abertura de dois cursos de direito: em São Paulo e Olinda. Esses três cursos por muito tempo seriam os formadores dos "doutores", título até hoje coloquialmente dedicado aos seus egressos. Além dessas escolas, no Segundo Império também foram fundadas algumas outras, como a Escola de Farmácia de Ouro Preto, a Escola de Minas e Metalurgia de Ouro Preto, as Academias Militares de Engenharia, além de alguns institutos de pesquisa. No período republicano, outras foram fundadas, algumas no estado de São Paulo, sobre as quais nos referiremos adiante. A partir dessas escolas isoladas é que outras instituições multidisciplinares seriam posteriormente fundadas ${ }^{79}$. Nesse ínterim, entretanto, não foram poucas as tentativas políticas de fundar uma universidade no país. Porém todas ficariam restritas aos discursos.

Se, no período colonial, a educação jesuítica tinha um modelo de origem europeia, o mesmo também se pode dizer desse período inicial da educação superior no território brasileiro. O modelo francês iluminista influenciou Coimbra, reformada em 1772 por Pombal e, a partir dali, as faculdades criadas no Brasil. O modelo enciclopédico, fundamentado nas cátedras, dividia com o ideal humboldtiano as posições que influenciavam o desenvolvimento do ensino superior brasileiro. Esse dualismo seria substituído, no período histórico posterior (republicano), pela contraposição entre positivistas e liberais: de um lado os que rejeitavam a ideia de uma universidade formadora, acreditando na equiparação entre os saberes técnicoprofissionais e acadêmicos; de outro lado os que defendiam "a universidade como palco de integração desses saberes amplos" ${ }^{80}$. Vence a posição liberal, porém apenas depois da vitória de Getúlio Vargas na década de 30.

\footnotetext{
${ }^{79}$ RODRIGUES (2001), pg.78 e CAMPOS (1954), pg. 31 e 58.

${ }^{80}$ RODRIGUES (2001), pg.79.
} 
Antes, porém, algumas experiências foram levadas a cabo. Em Manaus, sociedade enriquecida pelo ciclo da borracha, foi fundada uma universidade de vida efêmera, entre 1908 e 1926. Em São Paulo também houve uma experiência breve, entre 1911 e 1917. Essas experiências foram soterradas por um marco legal, a Reforma Carlos Maximiliano de 1915, que criava o Conselho Superior de Ensino, colegiado que reconheceria os novos cursos e que exigia certos parâmetros que inviabilizaram essas universidades, ao mesmo tempo facilitando a existência de entidades isoladas. Esse foi o caso da Universidade do Paraná, criada em 1912 e desmembrada em 1915, reunindo-se novamente em 1946 (federalizada e renomeada Universidade Federal do Paraná - UFPR - em 1951) ${ }^{81}$. Outra reforma, em 1925, nomeada Reforma Rocha Vaz, impôs critérios ainda mais restritivos, culminando, por exemplo, no fechamento da experiência amazonense. A Universidade Federal do Amazonas (UFAM) considera-se sucessora da Universidade de Manaus, já que a Faculdade de Direito que compunha essa instituição sobreviveu ao fechamento de 1926 como instituição isolada e foi depois incorporada pela UFAM, na sua fundação em $1962{ }^{82}$. A Universidade do Rio de Janeiro reuniu os cursos isolados da capital nacional, ainda que somente em 1937 se tornaria de fato uma universidade centralizada, com o nome de Universidade do Brasil ${ }^{83}$.

Em 1931 o governo de Getúlio Vargas, tendo como Ministro da Educação Francisco Campos, promulgou uma nova Lei de Diretrizes e Bases da Educação (LDB) e o Estatuto das Universidades Brasileiras, revogando as disposições préexistentes e pavimentando o caminho para a definitiva formação das universidades brasileiras. O estatuto permitia o funcionamento de entidades isoladas, mas regulamentava a formação de universidades públicas e livres (particulares). O modelo ainda preconizava a existência das cátedras, com professores selecionados por concursos públicos ${ }^{84}$. Essa base legal, somada às demandas sociais e ao trabalho intelectual de figuras proeminentes da educação brasileira culminou no projeto das primeiras universidades: a Universidade de Minas Gerais, a Universidade de São Paulo, a Universidade do Brasil (no Rio de Janeiro) e a Universidade de Porto Alegre.

\footnotetext{
81 RODRIGUES (2001), pg. 79 e CAMPOS (1954), pgs. 36-37.

82 http://www.ufam.edu.br/index.php/historia-da-ugm

83 CAMPOS (1954), pgs. 36-37 e ALBERTO (2004).

${ }^{84}$ RODRIGUES (2001), pg. 80.
} 
Antes de prosseguir com o caso das universidades brasileiras, cabe descrever como as instituições isoladas se localizavam e qual era sua relação com as cidades que as abrigavam. É importante frisar que na Proclamação da República o total de estudantes matriculados no nível superior no Brasil girava ao redor de 2.30085 . Portanto, mesmo nas cidades em que a existência de faculdades impactava o cotidiano, é preciso observar suas reduzidas dimensões. Esse pequeno corpo discente, no entanto, causava grande impacto cotidiano em uma cidade de pouca população e dinâmica econômica mais simples, como a São Paulo da primeira metade do século XIX (menos de trinta mil habitantes). Mas causava menor impacto na capital Rio de Janeiro, com quase trezentos mil habitantes, ou Salvador, com mais de cento e vinte mil habitantes, ou Olinda, que junto com Recife tinha população ainda maior no período.

Coincidentemente ou não, São Paulo foi fundada pelo jesuíta Manuel da Nóbrega em 1554 justamente com a finalidade de sediar um colégio para promover a educação do gentio. Também nessa cidade foi instituído um curso de medicina (cirurgia) em 1803, antes da fundação das faculdades em 1808 ${ }^{86}$. Seguindo essa vocação, após a fundação da Faculdade de Direito em 11 de agosto de 1827 a cidade passa a se tornar uma cidade acadêmica do modelo alemão, cujas instalações estavam localizadas em locais centrais da cidade. No caso de São Paulo a faculdade se instalaria no convento franciscano, em edifício pré-existente (depois substituído duas vezes até o prédio no qual se

Figura 197: O primeiro prédio da Faculdade de Direito.

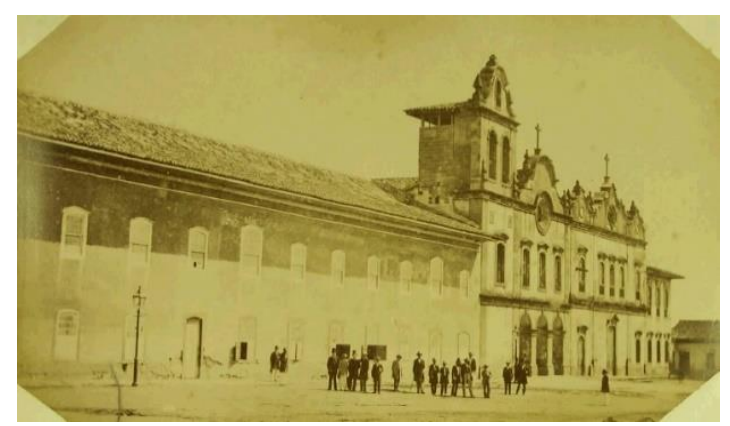

Fonte: Militão Augusto de Azevedo

Figura 198: O segundo prédio da Faculdade de Direito.

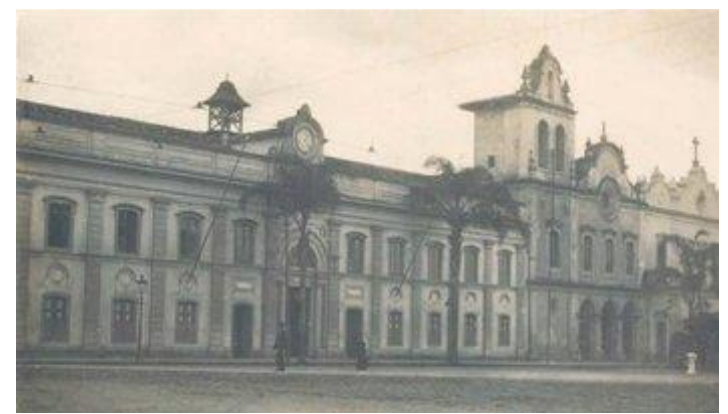

Fonte: http://www.direito.usp.br/index_faculdade.php

Figura 19: O terceiro prédio da Faculdade de Direito.

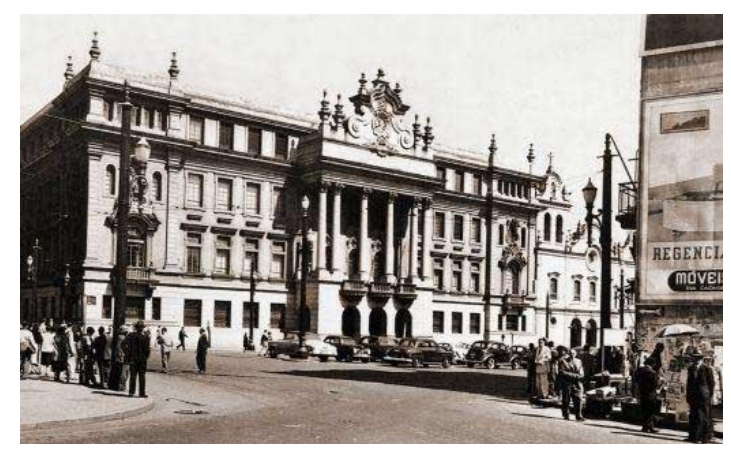

Fonte: Jornal da USP, ano XV, no 609, pg.14.

\footnotetext{
${ }^{85}$ RIBEIRO (1968), pg. 76.

${ }^{86}$ CAMPOS (1954), pg. 22.
} 
localiza hoje, conforme figuras 17 a 19) ${ }^{87}$.

A cidade de São Paulo na primeira metade do século XIX pouco diferia da cidade colonial. A área urbanizada se resumia a pouco mais do que atualmente chamamos de "triângulo histórico", ou seja, o trecho delimitado pelo Vale do Anhangabaú, o Rio Tamanduateí, a Rua Tabatinguera, a Praça da Liberdade e a Praça da Bandeira. As 4.200 construções eram de taipa, caiadas, encimadas por telhamentos cerâmicos. Abrigavam pouco mais de vinte mil habitantes, sendo apenas a metade nas freguesias centrais. A influência do tupi na fala dos paulistas desta época foi um recurso argumentado pelos adversários da instalação da faculdade de direito, devidamente contra-argumentado pelo papel civilizatório dessa instituição, na opinião dos fundadores. Alguns autores descreveram em pormenores o impacto da instalação da faculdade nessa pequena cidade, como Almeida Nogueira, nos nove volumes de Tradições e Reminiscência da Academia de São Paulo, escrito entre 1907 e 1912, Spencer Vampré em Memórias da Academia de São Paulo, dois volumes escritos em 1924, publicado pela Livraria Saraiva, e Ernani Silva Bruno, em História e Tradições da Cidade de São Paulo, volume II, publicado pela editora José Olympio, do Rio de Janeiro, em 1953. Esses e outros autores relevavam o espaço das "arcadas", como até hoje é conhecida essa faculdade, como um dos principais pontos da vida política e cultural do Brasil, além de ser "o maior laboratório de homens públicos do Brasil". A influência dessa comunidade sobre o cotidiano da cidade era muito poderosa, tanto em aspectos culturais como na oferta de comércio e serviços (tabernas, livrarias, vestuário, etc) ${ }^{88}$. Na segunda metade do século, os viajantes estrangeiros em seus relatos da passagem pela cidade de São Paulo reforçam esse aspecto. Chegam a determinar que a existência da faculdade de direito e a presença de seus quinhentos estudantes é que possibilitavam que a cidade mantivesse seu status de capital. No fim do século XIX, com o crescimento da cidade e o auge da centralidade urbana do ciclo do café, a presença da escola permaneceria significativa no que tange a vida cultural e política, mas seu impacto no cotidiano e na economia já não eram tão determinantes ${ }^{89}$.

O desenvolvimento da cidade, a partir da última década do século XIX, até as

\footnotetext{
87 Idem, pg. 54.

88 AB'SABER (2004), pg. 409.

89 MATOS (1955), pgs. 101-102. MARTINS (2004), pg. 18.
} 
primeiras décadas do século $\mathrm{XX}$, foi proporcionado, entre outros fatores, pela construção de casas para os "barões do café", que se alternavam entre a casa grande na fazenda e a nova casa na cidade. Parte desses proprietários usavam como pretexto acompanhar seus filhos ingressantes na escola superior, que era meta familiar e garantia de futuro com independência financeira ${ }^{90}$.

A história da faculdade que se instala em um convento, que por sua vez está localizado no centro de uma pequena cidade mercantil de um país periférico recém independente é no mínimo sui generis. De qualquer modo, não se pode diminuir a relevância dessa experiência, que ajudou a moldar o futuro da nação (ali estudaram 13 presidentes do Brasil, 48 governadores do Estado e São Paulo e várias outras personalidades da política e economia nacionais). Uma marca bastante significativa da apropriação cultural do lugar pela comunidade acadêmica é a placa datada de 30 de outubro de 1973, encravada no Largo São Francisco. Ali se lê a frase:

"Quantas pedras forem colocadas, tantas arrancaremos."

Esta frase refere-se à pretensão da Universidade de transferir para a Cidade Universitária, no Butantã, o curso de Direito, em um prédio novo. Os estudantes resistiram à mudança, retirando a pedra fundamental instalada pela administração e levando-a para o centro da cidade ${ }^{91}$.

Observando-se hoje as "arcadas" do Largo São Francisco, ainda percebemos interações entre a comunidade acadêmica e o entorno. A metropolização de São Paulo e a divisão funcional geográfica da cidade delegou ao centro um papel que exclui a moradia e a permanência. Os alunos se deslocam para o prédio da universidade majoritariamente nos horários de seus compromissos, reduzindo essas interações da comunidade com o entorno. Até hoje há eventos que resgatam a convivência, como a comemoração do dia 11 de agosto, a "Peruada" e, mais recentemente, eventos promovidos pela Prefeitura do Município nas praças próximas, bem como a permanência de comércios e serviços especializados.

A universidade brasileira surge após o estatuto geral promulgado em 1931 durante o primeiro governo nacionalista de Getúlio Vargas. Alguns grupos de intelectuais e políticos reunidos nos principais estados do país aproveitaram o ensejo

\footnotetext{
${ }^{90}$ AB'SABER (2004), pg. 273.

${ }^{91}$ MARTINS (2004), pg. 14.
} 
para criar as bases pedagógicas das futuras universidades. Em São Paulo, liderados por Fernando de Azevedo, formou-se o "Grupo do Estado". Em Minas Gerais, um grupo liderado por Francisco Campos, que foi o redator do Estatuto das Universidades. O mesmo se passa em Porto Alegre e com católicos do Rio de Janeiro, que fundariam os embriões da Universidade Federal do Rio Grande do Sul (UFRGS) e da Pontifícia Universidade Católica do Rio de Janeiro (PUC/RJ). Em 1937, também no Rio de Janeiro, então capital do país, renomeia-se a Universidade do Rio de Janeiro (fundada em 1920) para Universidade do Brasil, cuja re-fundação foi acompanhada com as discussões sobre a localização da Cidade Universitária (figuras 20 e 21), incluindo personalidades como Le Corbusier e Marcelo Piacentini ${ }^{92}$.

A questão pedagógica da formação das primeiras universidades no Brasil foi

Figura 210: Proposta de Le Corbusier de 1936.

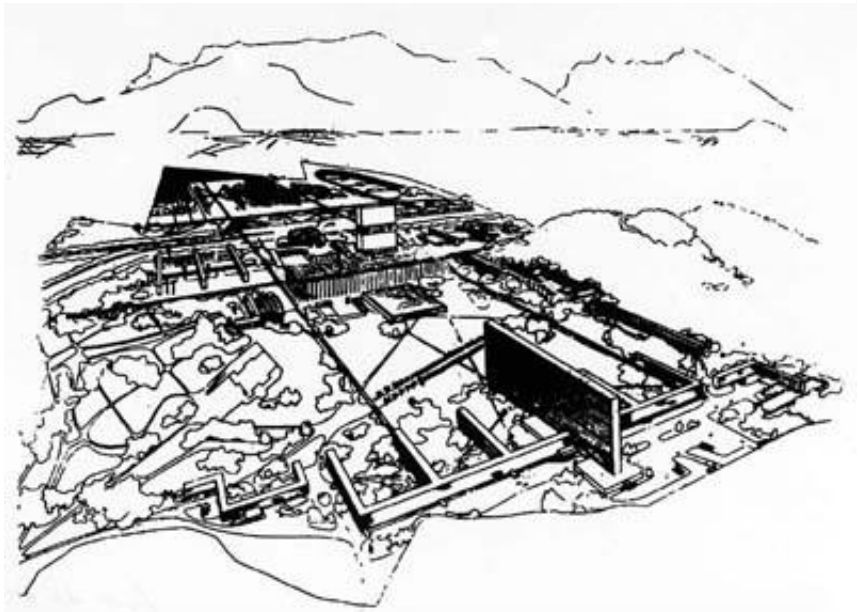

Fonte: http://www.urbanismobr.org/bd/documentos.php?id=1560 Figura 21: Proposta aprovada, de Jorge Moreira, de 1944.

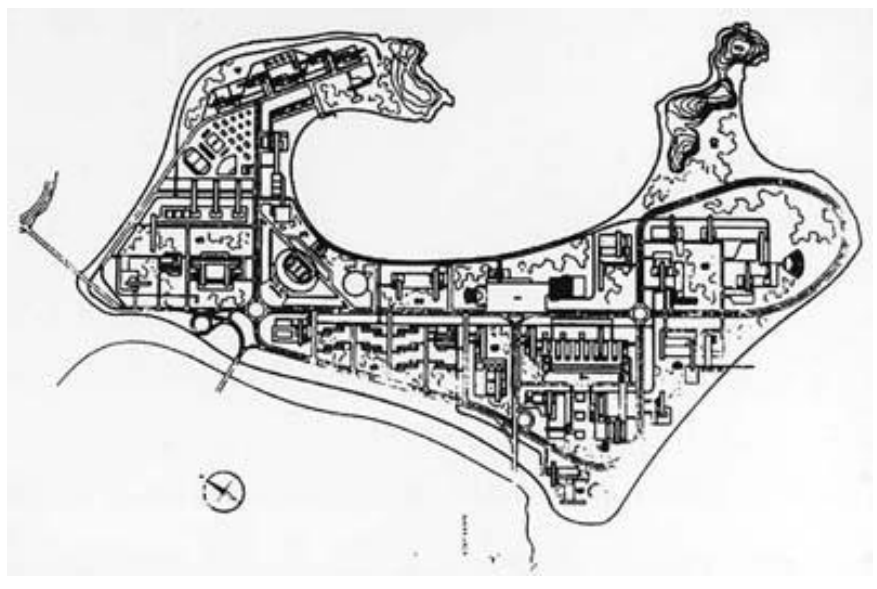

Fonte:

http://www.vitruvius.com.br/revistas/read/arquitextos/06.064/421 tratada por Darcy Ribeiro e Florestan Fernandes. Na opinião de Darcy Ribeiro, a fundação das faculdades de ciências e letras foi a solução brasileira para a formação de quadros intelectuais, integração da vida universitária, o espaço para o pensamento dos problemas gerais da educação e a incorporação do pensamento científico de maneira desvinculada com propósitos imediatistas, ou seja, a ciência como fim em si mesma. Ainda que, a princípio, essa proposta fosse adequada, a oposição das faculdades tradicionais (Direto, Medicina e Engenharia) em confiar a educação básica de seus ingressantes em outra faculdade fez com que os potenciais sucessos da experiência fossem apenas

92 RODRIGUES (2001), pg. 81. 
medianos. Pelo mesmo motivo, outra iniciativa que na opinião de Darcy Ribeiro não atingiu os resultados potenciais foi a divisão das unidades em departamentos, a fim de evitar a duplicidade ${ }^{93}$. Já para Florestan Fernandes nem essa solução poderia ser considerada inovadora ou suficiente para uma análise diferenciada. Em sua opinião não há qualquer novidade no processo de formação das universidades, já que o tipo de escola e a política educacional, ou seja, o padrão brasileiro de educação, deforma pedagogicamente o sentido do ensino superior. O que aconteceu nesse período e no próximo, foram apenas acréscimos numéricos ao sistema vigente, negligenciando a educação escolarizada como esfera básica da socialização do "homem comum" 94.

O ambiente intelectual no Estado nos anos 30 era reflexo da economia pujante, de um movimento cultural e artístico em constante renovação e um processo de aglutinação em torno de ideais desenvolvimentistas. A economia pujante, tendo na base a industrialização intensa e ainda a cultura cafeicultora, tinha reflexos, por exemplo, na intensa urbanização. O movimento cultural e artístico que se iniciara nos anos 20 - o modernismo paulista - com suas características "antropofágicas" (reunindo a vanguarda estrangeira e a cultura tradicional brasileira), vivia seu período mais profícuo. O que é muito coerente, ainda mais em uma cidade que contava com quase metade de sua população vinda de outros países ${ }^{95}$. Finalmente, o processo de aglutinação em torno de ideais desenvolvimentistas pode ser considerado atrasado, já que alguns de seus objetivos haviam sido atingidos na Europa há muito tempo: o controle da exploração de mão-de-obra infantil, a oferta de ensino público e gratuito, a conquista de direitos de liberdade civil, etc.

Politicamente a situação era complexa: acostumada a décadas de poder, a elite paulista sofreu um imenso revés com a tomada de poder de Getúlio Vargas. O mesmo que permitirá a ascensão de algumas daquelas personalidades que ensejaram a fundação da Universidade de São Paulo e das Escolas Práticas de Agricultura. Se, em um primeiro momento, os reflexos da derrota paulista durante a Revolução Constitucionalista de 1932 são o efetivo alijamento do poder da elite paulista, logo depois algumas personalidades se aproximam do governo e ocupam posições

\footnotetext{
93 RIBEIRO (1968), pg. 118.

94 FERNANDES (1975), pg. 51.

95 FAUSTO (2009), pg. 10.
} 
importantes. Em especial, após o período de maior instabilidade política, que perdurou de 1930, da instalação do regime, até 1937.

O "mito moderno" Getúlio Vargas cercava-se de personalidades que se corresponsabilizaram com o projeto modernizante do país. Um exemplo, Fernando Costa, que havia sido prefeito de uma pequena cidade do interior (Pirassununga) e Secretário de Agricultura do Estado, político de centro-direita que despontava por seu pragmatismo, mais do que por sua habilidade oratória ${ }^{96}$. Getúlio Vargas não hesita em fazê-lo Ministro da Agricultura, entre 1937 e 1941, de onde saiu para assumir o cargo de Interventor no Estado de São Paulo. Fernando Costa havia sido Prefeito de Pirassununga e deputado estadual, para onde se candidatou de maneira independente, sem vincular-se a partidos ${ }^{97}$. Mais tarde, vincular-se-á ao Partido Social Democrático (PSD), fundado por Getúlio Vargas para reunir seus apoiadores, depois do período ditatorial, onde pretendia lançar-se candidato a Governador (mas falece em um acidente de automóvel, antes das eleições). Tinha o que hoje se denomina "perfil técnico", políticos que proferem discursos técnicos para legitimar suas ações - e isso se comprova em seus discursos publicados.

Outra figura importante que se aproximará de Getúlio Vargas é Armando de Salles Oliveira. De apoiador da Revolução de 32 passou a interventor federal em 1933, escolhido por suas boas relações tanto com os ex-revolucionários quanto com 0 governo federal, a ponto de indicar ministros ${ }^{98}$. Durante seu governo foi fundada a Universidade de São Paulo, em 1934. Neste ano, havia em São Paulo mais cinco instituições de ensino superior, todas privadas.

O Decreto Estadual 6.283 de 25 de janeiro de 1934, assinado pelo interventor Armando de Salles Oliveira, instituiu a Universidade de São Paulo. Ele foi um dos integrantes do chamado "Grupo do Estado", que reunia também o presidente do jornal O Estado de São Paulo, Júlio de Mesquita Filho e o pedagogo Fernando de Azevedo, a quem coube o projeto pedagógico da nova instituição. Esse grupo trabalhou politicamente para a criação da Universidade. Seu primeiro passo foi a realização de um inquérito pelo jornal, que tinha entre seus redatores Fernando de Azevedo. Vários

\footnotetext{
96 MENUCCI, Sud in COSTA (1944), prefácio.

97 TELES e IOKOI (2005), pg. 34.

98 https://cpdoc.fgv.br/producao/dossies/AEraVargas1/biografias/armando_sales
} 
especialistas foram ouvidos e um relatório a favor da Universidade foi datado de $1^{\circ}$ de dezembro de 1928. Seguiram-se diversas articulações, com a participação de ilustres professores, como Vitor da Silva Freire, Theodoro Ramos (que se responsabilizou pelos contatos com os professores estrangeiros), Vicente Rao (depois Ministro da Justiça) e o próprio Ernesto de Souza Campos ${ }^{99}$.

O Decreto reunia as faculdades pré-existentes: a tradicional Faculdade de Direito, fundada em 11 de agosto de 1827 pelo primeiro imperador do Brasil; a primeira instituição de educação superior fundada pelo governo do Estado de São Paulo, a Escola Politécnica, de 15 de fevereiro de 1894; a Faculdade de Medicina, fundada em 1912; a Faculdade de Veterinária, fundada em 1909; a Escola Superior de Agricultura Luiz de Queiroz, fundada em 1899 100; e a Faculdade de Farmácia e Odontologia, recém-reformada, porém com origens também em 1899. O entrelaçamento entre essas instituições pré-existentes seria dado pela Faculdade de Filosofia, Ciências e Letras, criada conjuntamente com a Universidade ${ }^{101}$.

A conquista de espaço próprio para esta nova instituição é uma epopeia, narrada na tese de doutoramento de Neyde Ângela Joppert Cabral (figura 22). Um personagem de grande relevância nessa epopeia é Ernesto de Souza Campos, médico e ex-diretor da FMSP e da FFCL (que na época era escrita FPSL - Faculdade de Philosophia, Sciencias e Letras) ${ }^{102}$. É dele a primeiro registro sobre a história da USP, escrito aos 20 anos de existência da Universidade e uma grande referência sobre as ideias que nortearam as ações de seus fundadores.

Figura 22: Os primeiros projetos para a Cidade Universitária da USP.
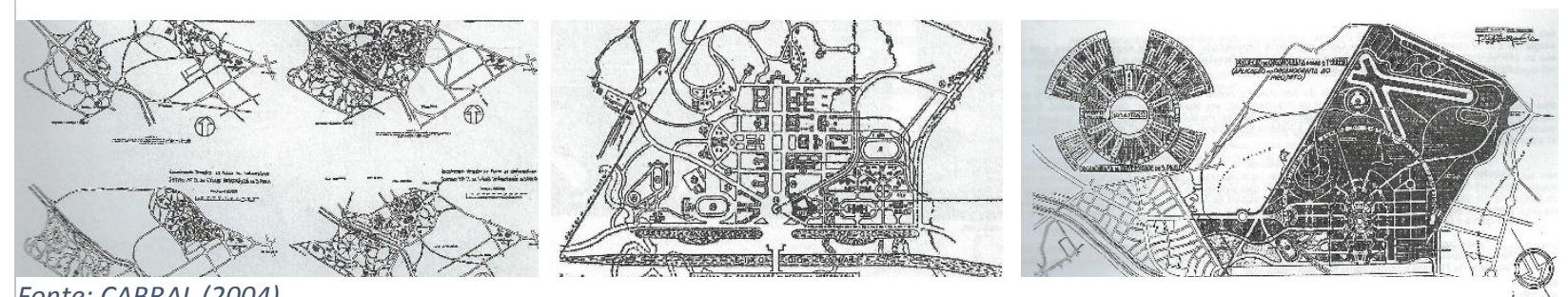

Fonte: CABRAL (2004).

${ }^{99}$ CAMPOS (1954). Sobre a história da Universidade, há vasta bibliografia. A que reúne os documentos de período mais próximo dos fatos é "A História da Universidade de São Paulo", do médico Ernesto de Souza Campos, especialmente importante pois foi escrita por um personagem que foi aluno e docente da Universidade em seus primeiros anos, além de membro de todas as comissões de espaço físico durante o período de seu vínculo como docente. Ver também MOTOYAMA (2006), pg. 25.

100 O decreto de fundação é de 1892, a implantação do ensino superior é de 1912. MENDES (1977), pg.5.

101 CAMPOS (1954), pg. 69.

102 XAVIER (2004), pg.45. 


\subsection{Os territórios universitários do meio rural}

A história da universidade tem seus primeiros séculos intrinsecamente interligados com a história das cidades. Durante a Baixa Idade Média, no contexto de decadência do feudalismo e crescimento do mercantilismo, as cidades aos poucos vão retomando sua importância, perdida no período anterior. Em algumas delas, o fator de recuperação e desenvolvimento foi a fundação das universidades. Por sua vez, as universidades medievais localizavam-se invariavelmente em centros urbanos, em localidades que possibilitassem seu desenvolvimento, tanto no período em que eram autogeridas, quanto no período em que se tornam dependentes ou submetidas às autoridades governamentais. Qualquer vínculo com a realidade rural, tanto no aspecto acadêmico quanto no aspecto de sua própria espacialidade, aparecerá apenas na experiência transatlântica, quando o modelo dos Estados Unidos surge e torna-se influenciador para todo o mundo.

A experiência norte-americana, caracterizada pelo afastamento da cidade pelo julgamento de seus "vícios", remete a uma paisagem que certamente não é urbana, ainda que também não seja rural. Os "campi" norte-americanos eram áreas relativamente próximas da cidade, periféricas, que com o crescimento delas acabaram sendo incorporados ao tecido urbano. Mas, mesmo no período de suas fundações, quando os territórios universitários ainda não estavam incorporados nesse tecido urbano e nem eram densamente edificados, ainda tinham seus vínculos com a cidade: suas funções eram tradicionalmente urbanas - como o ensino e depois a pesquisa, e o trânsito frequente de pessoas entre os dois territórios, da cidade e da universidade. Como vimos previamente, os "campi" eram áreas planejadas e, quase sempre, pensadas com uma reserva de área para efetiva expansão da instituição universitária. Essas condições, ainda que não permitam que denominemos essas áreas de "urbanas", também não permitem que as denominemos "rurais". Pois essas são demarcadas por outras características, como a produção de animais ou plantações, o envolvimento em uma economia agrícola, a presença de trabalhadores do campo, o cotidiano mais afastado da urbanidade e suas facilidades. 
O desenvolvimento da agricultura e da pecuária, bem como da tecnologia de transformações básicas de matérias primas resultou na necessidade de aprimoramento da mão de obra especializada, além do treinamento gerencial para as empresas do campo. Paralelamente, há o desenvolvimento do conhecimento de fisiologia animal e vegetal, proporcionado pelos avanços nos estudos de química e biologia. Essas condições culminam no nascimento do ensino superior de agronomia e áreas correlatas. Conjuntamente, nascem os espaços indicados para as práticas específicas de ensino. Esse é o efetivo surgimento dos territórios universitários no meio rural.

Para compreender melhor, faremos um breve resgate do ensino superior de agricultura e pecuária, nos Estados Unidos, na Europa e no Brasil, partindo das duas experiências realizadas no período imperial, passando pela visão de Luiz de Queiroz e a implantação das faculdades rurais em Seropédica, no Rio de Janeiro; Areia, na Paraíba; e Belém do Pará, até a instituição das Escolas Práticas de Agricultura no Estado de São Paulo, principal foco deste trabalho.

\subsubsection{Ensino superior no campo}

O estudo das ciências agrárias se inicia vinculado ao estudo de biologia. Um bom exemplo são os estudos de Gregor Mendel na República Tcheca no século XVIII, na área de fertilização e genética. De maneira mais independente, as primeiras escolas de ciências agrárias aparecem nos Estados Unidos, a partir do Hatch Act de 1887 , que destinava fundos federais para determinadas escolas que inaugurassem estações experimentais de agricultura. Essas escolas teriam obrigatoriamente de ser vinculadas ao Morril Act de 1862, que foram criadas ou ampliadas em terras doadas pelo governo federal para incentivar o ensino de áreas não clássicas, como engenharia e a própria agricultura ${ }^{103}$.

Se a educação de nível superior no campo se inicia nos Estados Unidos, a história dos territórios específicos para essa finalidade não poderia surgir em outro lugar. Ali estão as primeiras experiências de planejamento de espaços para essas

\footnotetext{
103 Sobre esta legislação, consultamos o sítio http://lawhigheredu.com/90-morrill-acts.html, acessado em 22/10/2016 e TURNER (1983), pg. 129.
} 
finalidades. A primeira experiência citada por Turner são as farmers schools de New York e Ohio, que no entanto não tiveram grande sobrevida, permanecendo abertas entre os anos 1840 e 1850. Depois, cita uma escola de agricultura no Estado de New York, projetada por Alexander Jackson Davis em estilo eclético, com arquitetura "simples", no ano 1850, porém nunca construída ${ }^{104}$. Só depois do Morril Act e mais especificamente do Hatch Act, é que aparecerão exemplos efetivamente construídos.

Entre as experiências seminais, as que mais se destacam são os projetos e obras de Frederick Law Olmsted e depois de seu escritório, gerenciado por seu filho. Entre os anos de 1860 e 1890, Olmsted esteve engajado no planejamento de mais de 30 planos de territórios universitários (figuras 23 e 24). Nas palavras de Turner, Olmsted acreditava em um "idealismo democrático e um compromisso com o bemestar da classe trabalhadora", bem como a "crença que a sociedade americana teria de civilizar-se para ter sucesso" ${ }^{105}$. Após uma visita à Inglaterra em 1850, retornou para os Estados Unidos pensando em reproduzir a proposta de educação superior para as classes populares. Conheceu o paisagista Andrew Jackson Downing que foi auxiliar de Davis no projeto não executado da escola de agricultura do Estado de New York. Downing também publicou um artigo em uma revista editada por Olmsted, no qual defendia a combinação das práticas e teorias na nobreza da vida rural ${ }^{106}$. Essas influências marcaram Olmsted em seu trabalho posterior.

Figura 243: Trinity College (1872).

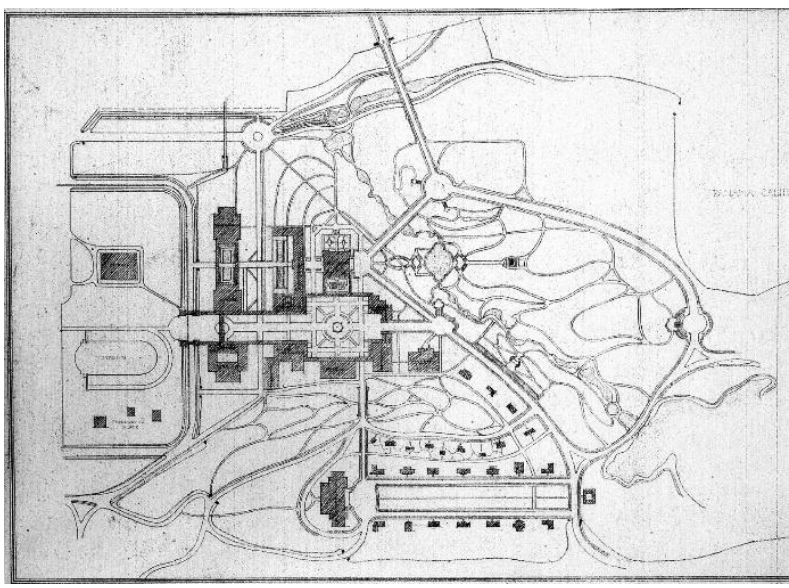

Fonte: Journal of the Society of Architectural Historians, Vol. 70 No. 1, Mar 2011; (pp. 64-81)
Figura 24: Bryn Mawr (1892).

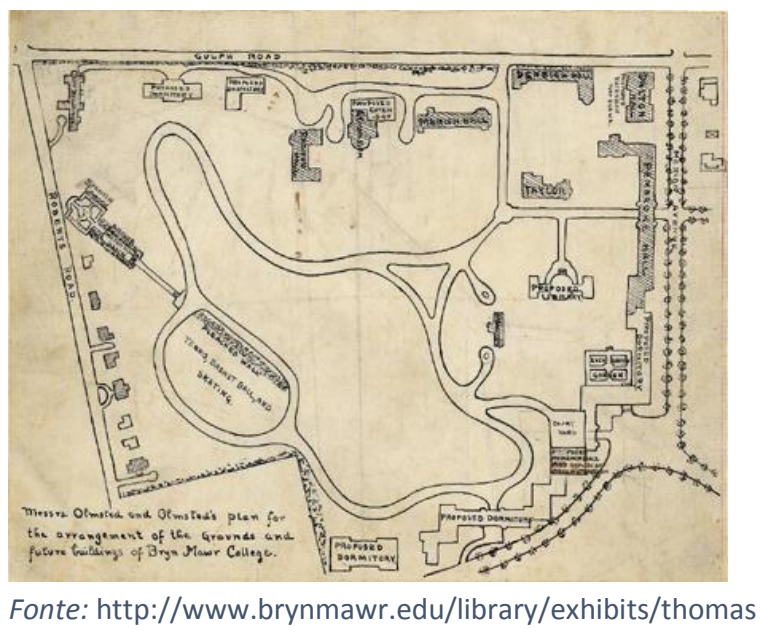

Fonte: http://www.brynmawr.edu/library/exhibits/thomas

104 Id., pg. 124.

105 Ibid., pg. 140.

106 Ibid., pg. 141. 
Posterior ao Morril Act, quando esteve trabalhando na California, Olmsted foi responsável pelo projeto da urbanização de Berkeley. Ali realizou um plano de longa duração, que tem como principal mérito a concepção do território universitário entremeado a outros usos, como parte de uma comunidade maior. No relatório sobre a implantação de Berkeley, Olmsted defende que os territórios universitários não devem nem estar no meio do campo (divorciado da vida doméstica) nem no meio da cidade. Do ponto de vista estilístico, Olmsted assume um projeto pinturesco ${ }^{107}$.

Em 1866 Olmsted foi contratado para realizar o projeto de sua primeira escola de agricultura: o Massachusetts Agricultural College em Amherst (figura 25, atualmente parte da Universidade de Massachusetts). Depois, projetou o Maine Agricultural College (depois Universidade do Maine, em Orono), o Pennsylvania Agricultural College, o Hampton Institute na Virgínia e a Cornell University. Tendo o projeto daquele primeiro contrato como modelo, redigiu um artigo que estabelecia padrões para as escolas nacionais de agricultura. Nesse artigo, dizia:

"you must embrace in your ground-plan arrangements for something more than oral instruction and practical demonstration in the Science of agriculture... you must include arrangements designed to favorably affect the habits and inclinations of your students, and to qualify them for a wise and beneficent exercise of the rights and duties of citizens and of householders ${ }^{108 . "}$

Figura 25: Mapa da década de 1910, posterior ao plano de Olmsted para o MAC.

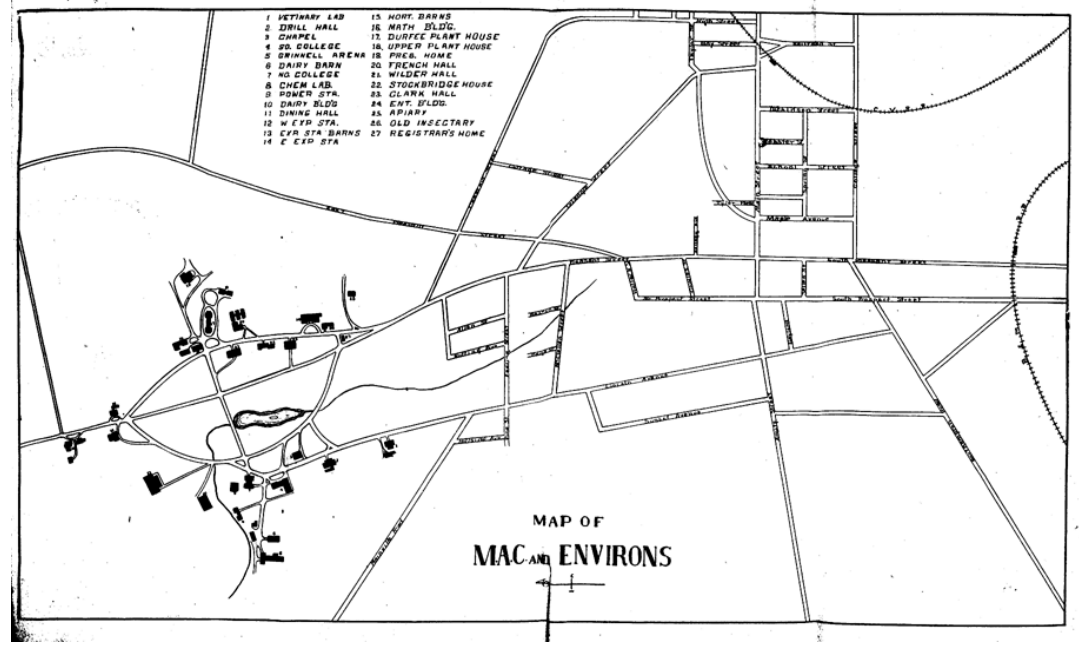

Fonte: http://clio.fivecolleges.edu/umass

Ainda que nem todos seus planos tenham se concretizado, é notável sua influência sobre o planejamento dos territórios das escolas de agricultura, que apareceram em praticamente todos os estados norteamericanos. Ao invés

107 RANNEY (1990), pg. 554.

108 Ibid., pg. 142. Em tradução livre: "você deve abraçar em seus planos territoriais arranjos para algo mais do que instrução oral e demonstração prática em Ciências da Agricultura... você deve incluir arranjos projetados para afetar favoravelmente os hábitos e inclinações de seus estudantes, e qualificalos para o sábio e beneficente exercício dos direitos e deveres de cidadãos e proprietários". 
das grandes construções com pátios, formando os quadriláteros, propunha construções situadas ao longo de ruas curvilíneas, parqueadas, com alternativas separando vias carroçáveis e de pedestres. Em um determinado ponto, uma grande construção central aparece como ponto focal do campus. Como planejamento, a ideia de Olmsted era a confecção de um plano com ideias gerais, bem flexível, com possibilidade de expansão em pequena escala, com edifícios relativamente pequenos, espalhados pelo território. Essa ideia também reflete a expressão dos "modestos valores rurais" em contraste ao "formalismo e elitismo das escolas tradicionais" 109. Apenas como exemplo, é possível observar o projeto da lowa Agricultural College (atual Universidade de lowa), que foi modificado após o contato de seus dirigentes com a obra de Olmsted (figura 26) ${ }^{110}$.

Figura 26: lowa Agricultural College

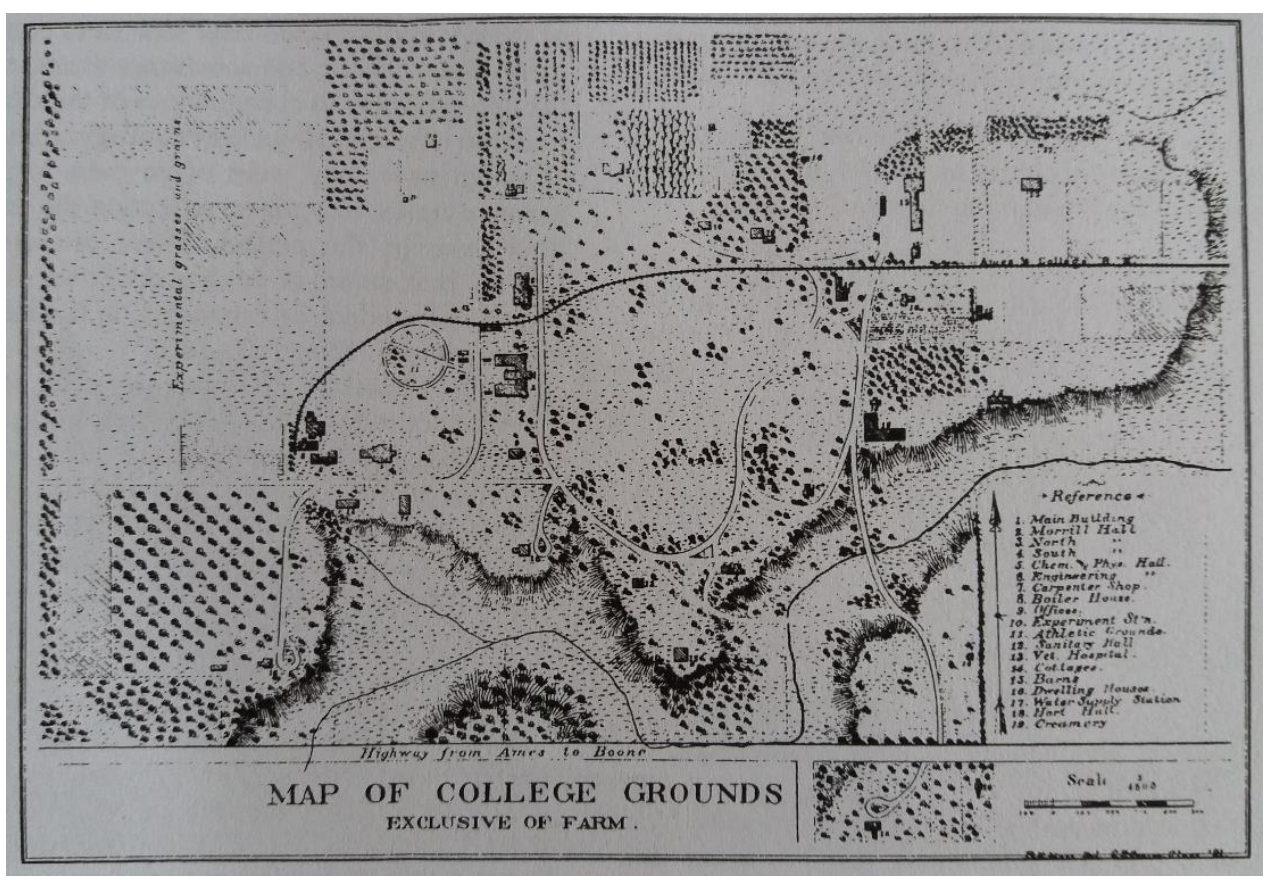

Fonte: TURNER (1984), pg. 149.

Com o tempo soluções híbridas foram se encadeando, do ponto de vista da relação do território com a cidade. Há uma grande diversidade de modelos, desde as primeiras escolas de agricultura até as experiências atuais. Sobre os aspectos apenas formais, é possível resumi-los em cinco modelos:

\footnotetext{
109 lbid., pg. 147.

110 lbid., pg. 150.
} 
a) Recortes de território situados em setores limítrofes de campus suburbano (a implantação típica de escolas norte-americanas). Um exemplo é a Universidade de Auburn (figura 27);

b) Recortes de territórios situados em qualquer área de um campus suburbano. Um exemplo é a Universidade Cornell (figura 28);

c) Território emulando uma fazenda, dentro de um recorte de um campus. Um exemplo é Universidade de Illinois em Urbana-Champaign (figura 29). No Brasil, um caso sui generis é a UFRA: em um recorte da instituição rural,

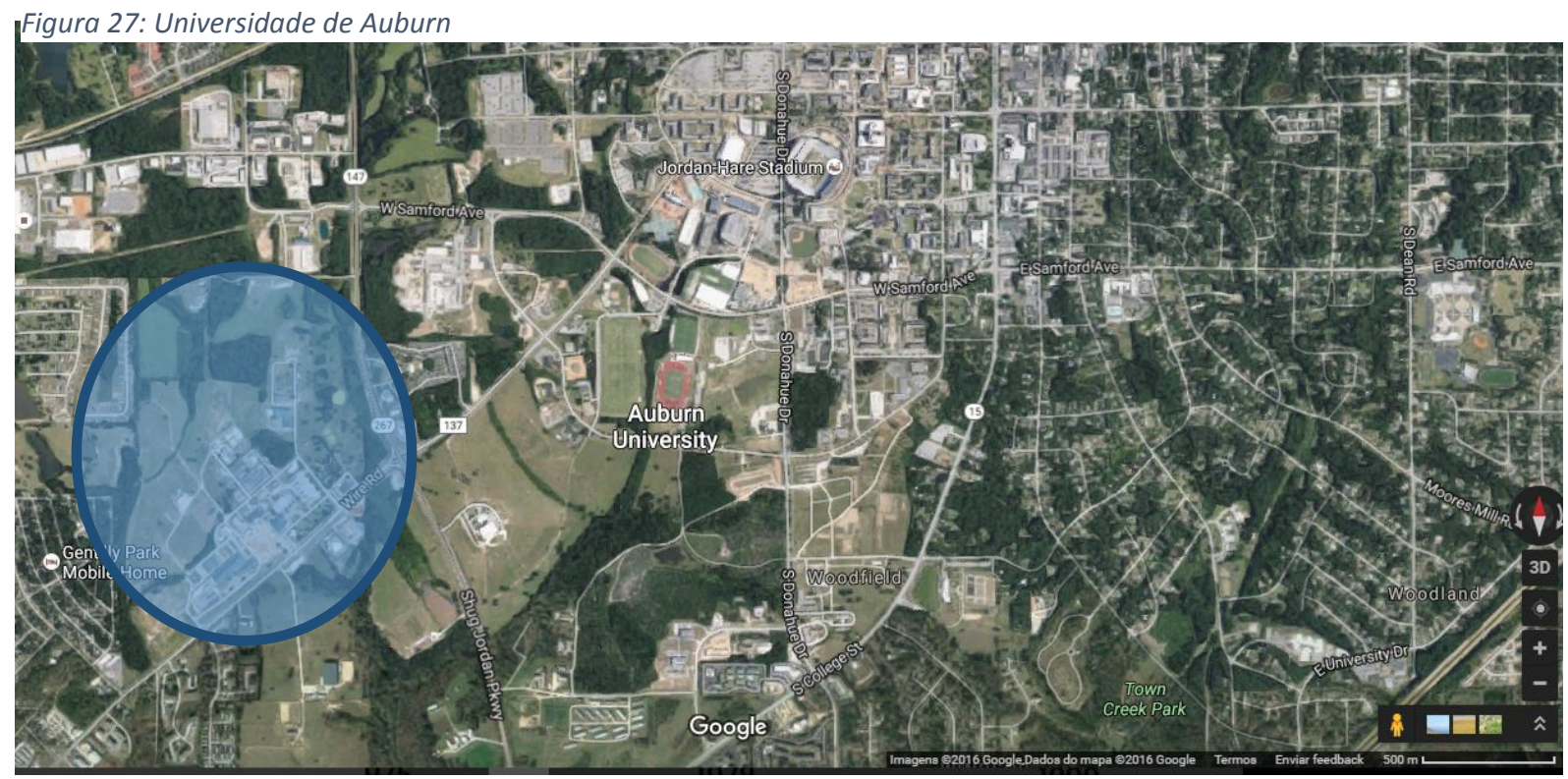

Fonte: Google Earth

Figura 28: Cornell University

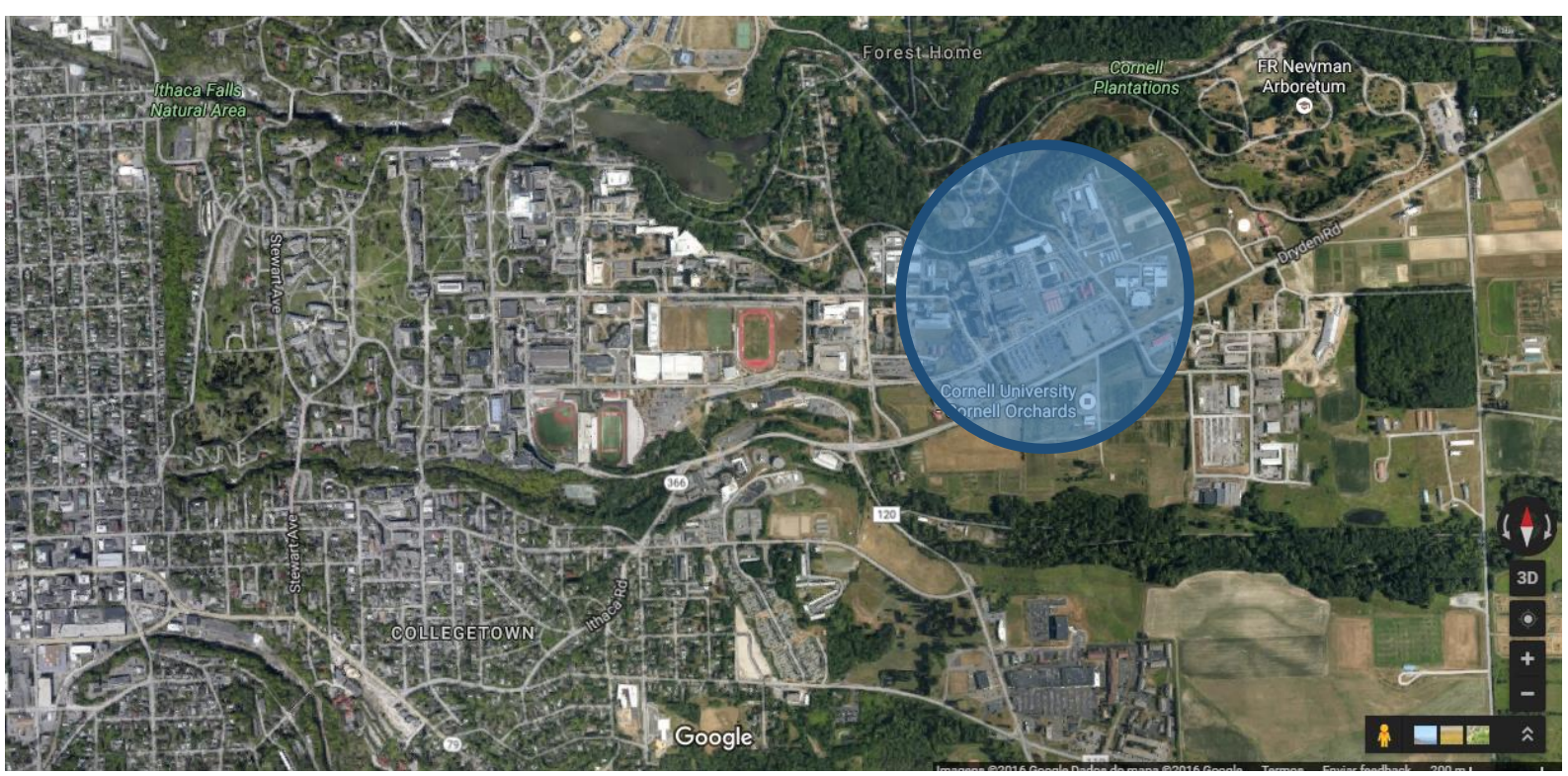


em sua porção mais próxima da cidade, foi construída outra instituição, tipicamente modernista (figura 29);

d) Território tipicamente rural que foi alcançado pelo desenvolvimento da trama urbana ao longo das décadas. Um exemplo é a McGill University (figura 30). No Brasil, podemos considerar os casos da ESALQ, da UFRRJ, e do Campus Fernando Costa como exemplares;

e) Território emulando uma fazenda, compreendendo todo o campus. Em alguns casos, sendo alcançados pelo desenvolvimento da trama urbana ao

Figura 29: Universidade de Illinois em Urbana / Champaign.

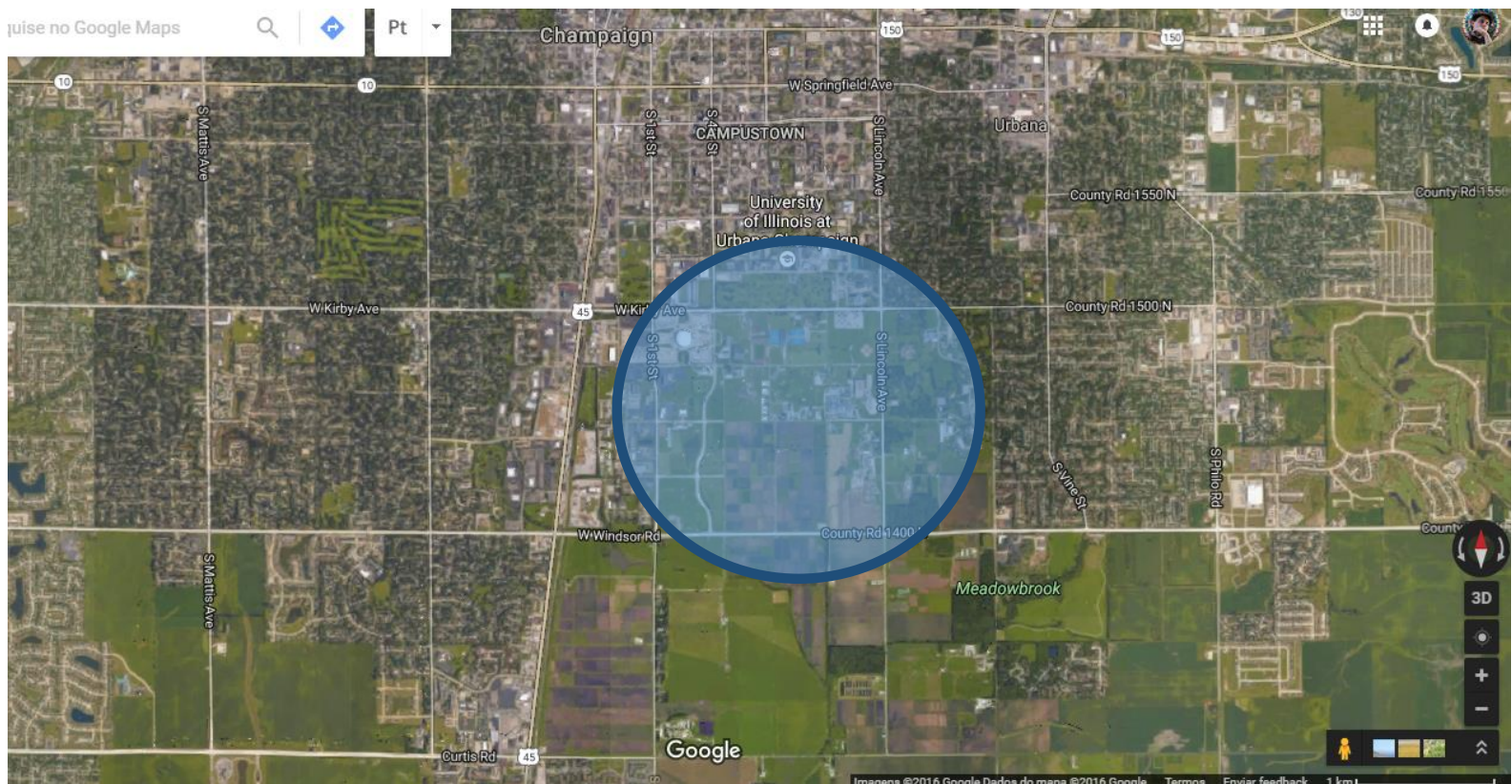

Fonte: Google Earth

Figura 30: McGill University

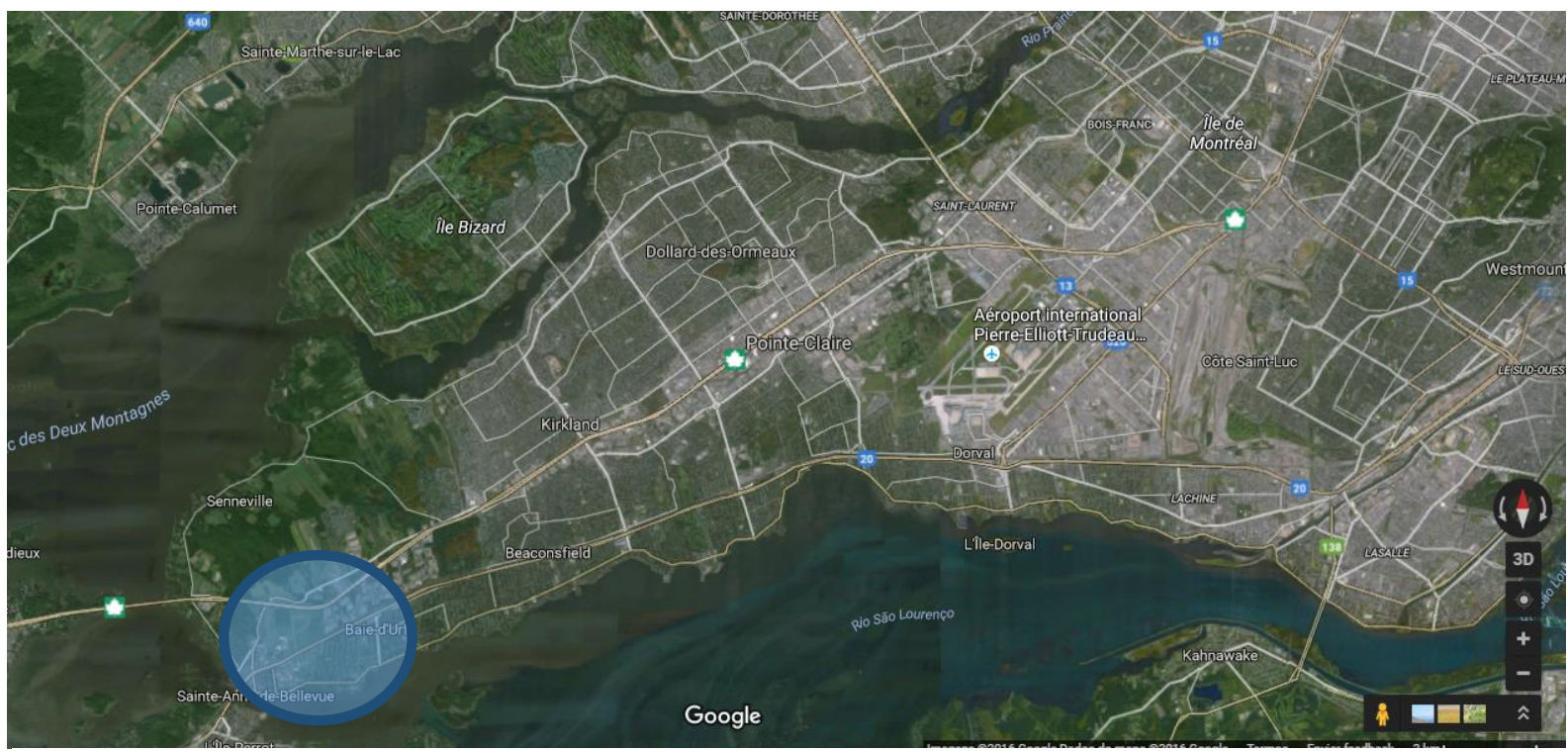




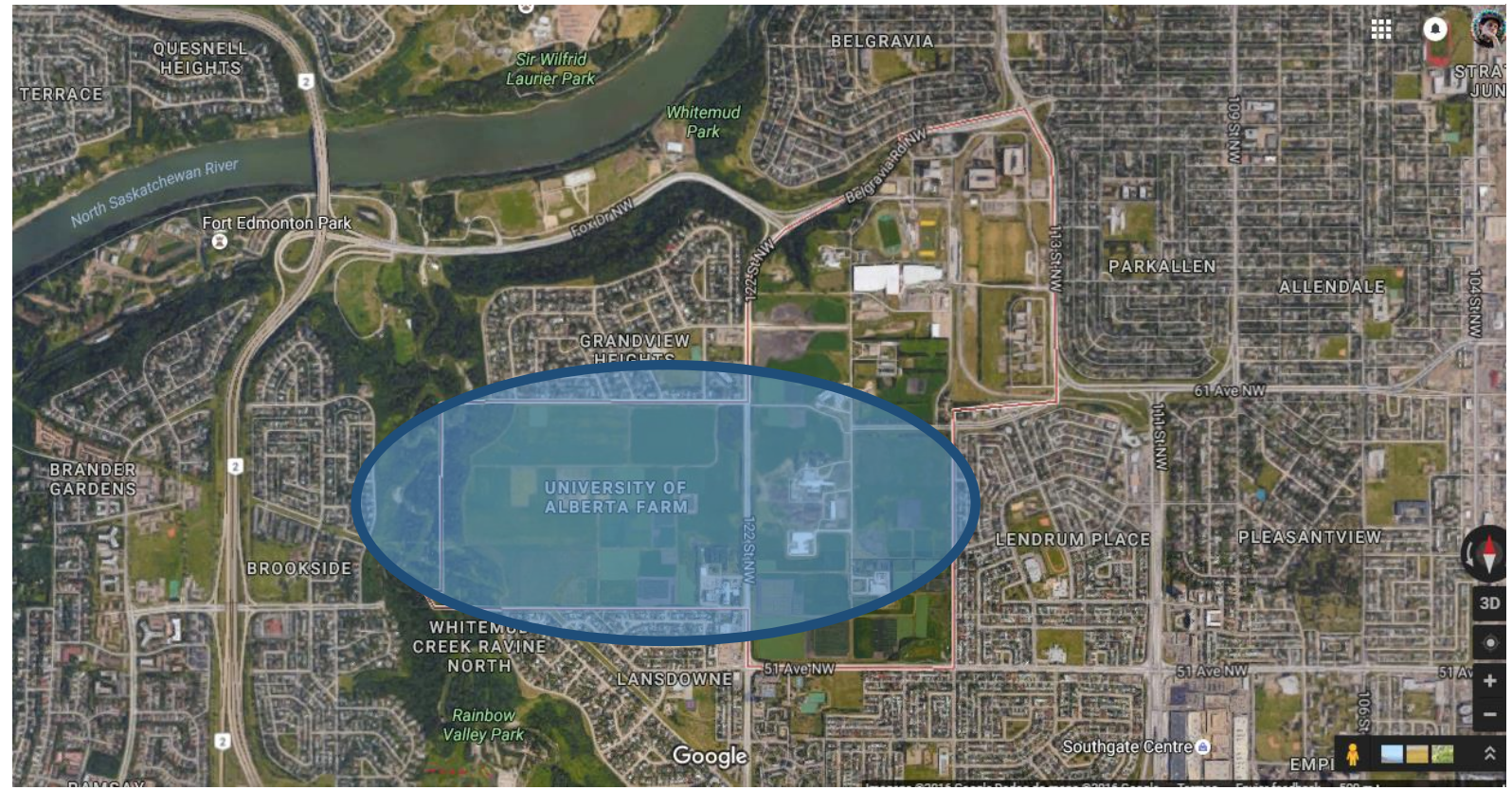

Fonte: Google Earth

Figura 32: Butte College

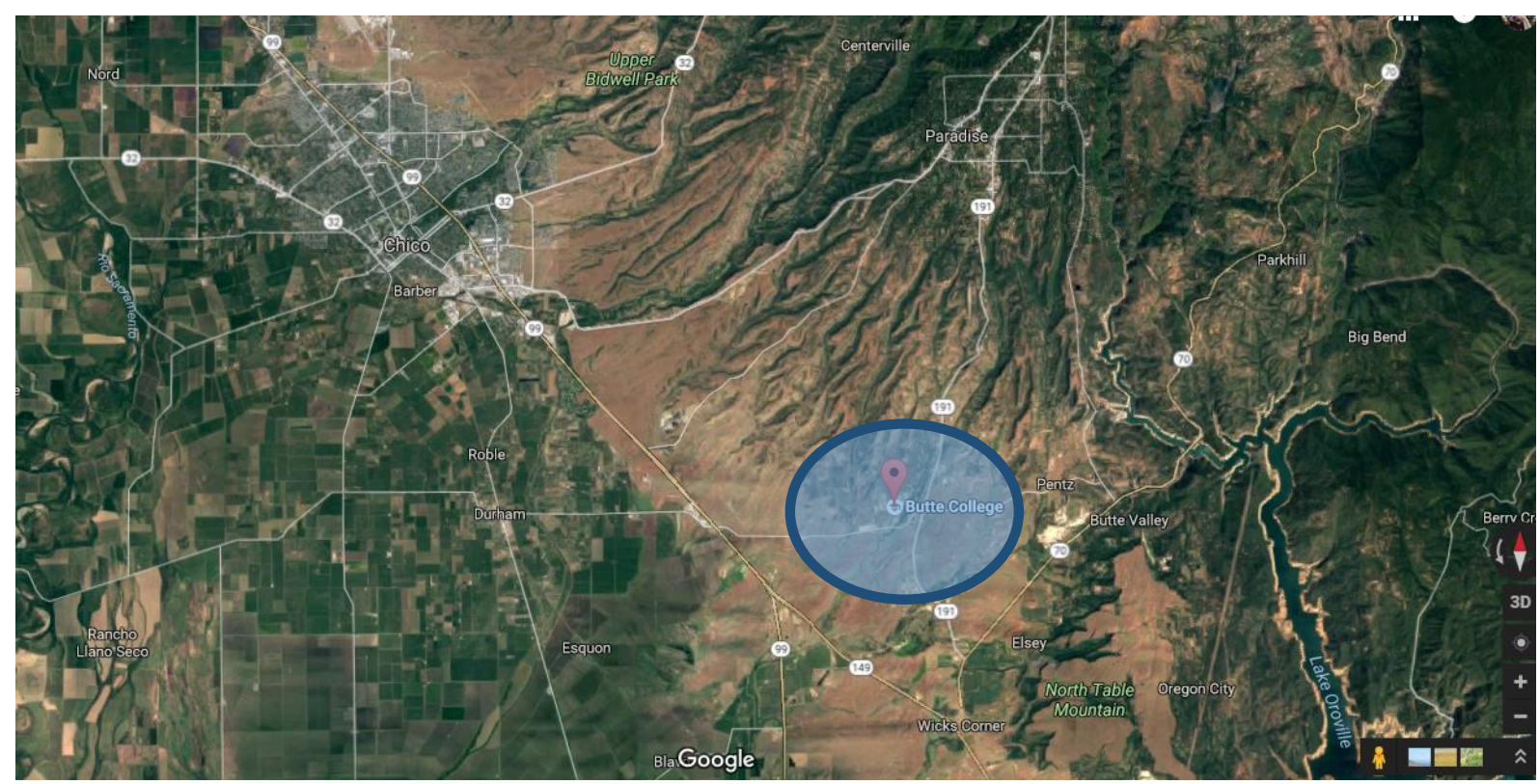

Fonte: Google Earth

longo das décadas, como a Universidade de Alberta (figura 31), em outros, continuando como território tipicamente rural, como o Butte College (figura 32). No Brasil, os casos da UFPB-Campus Areia, e da Universidade Federal de Pelotas (UFPel) assim se caracterizam.

Uma última observação refere-se ao ensino técnico no campo, que foi a função inicial das Escolas Práticas de Agricultura. Uma década antes das realizações nacionais, que serão tratadas a seguir, o México já havia construído escolas agrícolas, 
com características funcionais e estéticas relativamente próximas das nacionais. Bom exemplo é a antiga Escuela Normal Agricola, de Emílio Mendez Balzaretti, de 1936 (figura 33, atualmente parte da Universidad Veracruzana) ${ }^{111}$. A influência do programa de construção de escolas deste país ressoa no Brasil e influencia alguns arquitetos ligados à proposta modernizante da arquitetura neocolonial.

Figura 33: Escuela Normal Agricola

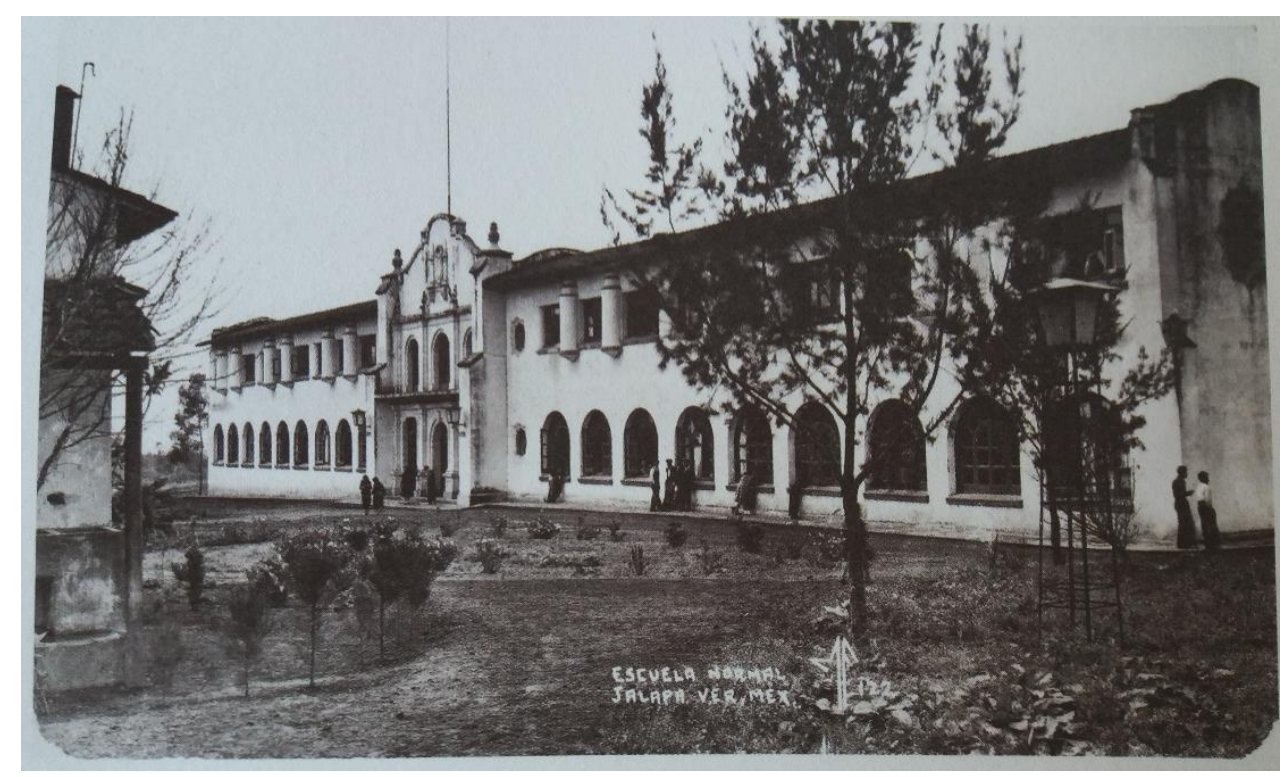

Fonte: ARAÑO (2011), pg. 96.

\subsubsection{Ensino superior no campo no Brasil}

No Brasil as primeiras experiências de ensino superior de ciências da terra são as duas escolas de agronomia do período imperial. Na Bahia, o Imperial Instituto Bahiano de Agronomia foi fundado por um decreto de 1859, porém instalado apenas em 1877, em São Francisco do Conde, no interior do Estado. Essa escola teve vida efêmera, sendo desativada em 1904, reaberta no ano seguinte e definitivamente fechada em 1910, preservando-se, porém, o curso técnico ali oferecido. Suas instalações, centralizadas em um edifício principal com duzentas janelas, encontramse hoje em ruínas (figura 34). O ensino superior de agronomia e ciências da terra na Bahia foi retomado somente no ano de 1938, a primeira turma formando-se em 1943, com a fundação da Escola Agronômica da Bahia, com instalações na cidade de Cruz

111 ARAÑO (2011), pg. 96-97. 
Figura 34: Ruínas do Imperial Instituto Bahiano de Agronomia.

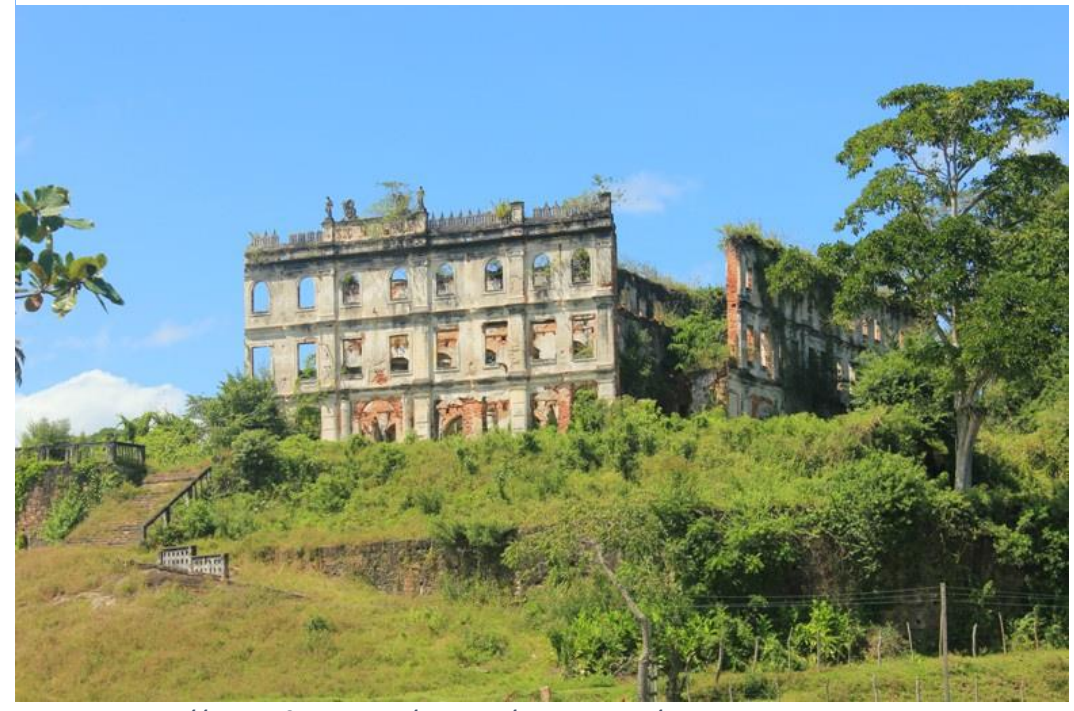

Fonte: https://www.flickr.com/photos/eddborges/6071398675, por Edvaldo

Figura 35: Campus Capão do Leão da UFPel.

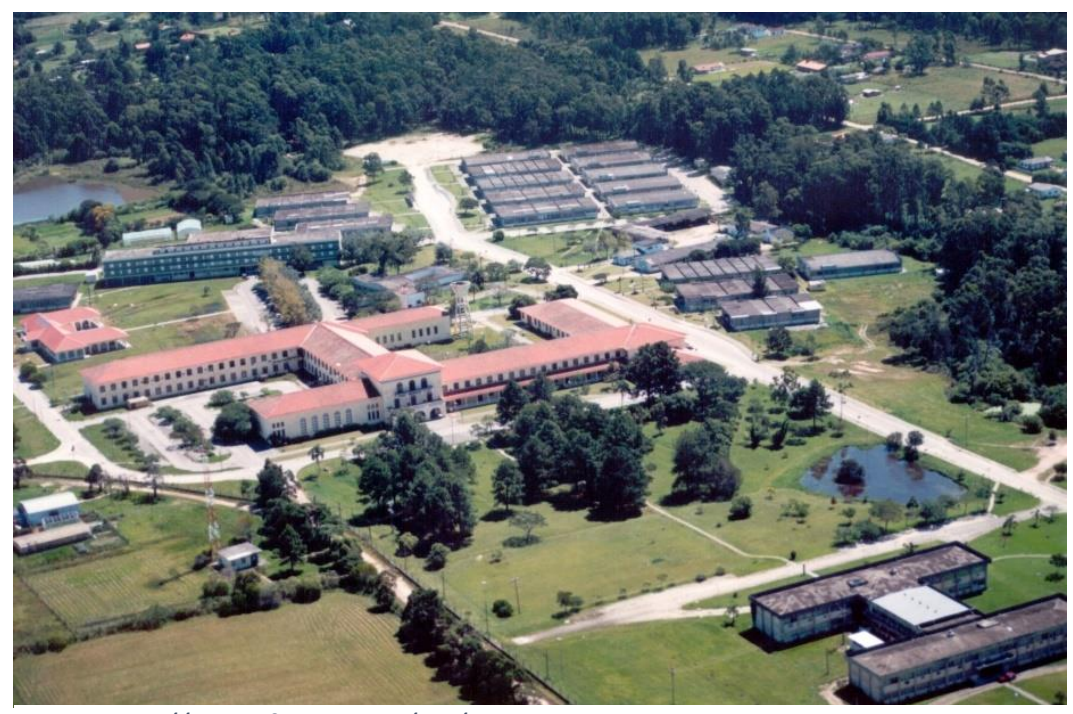

Fonte: http://ccs2.ufpel.edu.br/wp/

das Almas 112. Essas

instalações, depois

repassadas à

Universidade Federal da

Bahia (UFBA), deram origem à segunda universidade federal do estado, a Universidade Federal do Recôncavo Baiano (UFRB), fundada em 2006.

A segunda escola do período imperial é a Imperial Escola de Medicina Veterinária e de Agricultura Prática, fundada em 1883, na cidade de Pelotas, no Rio Grande do Sul. Entre idas e vindas do período de instalação, os dois primeiros formandos em agronomia recebem seus diplomas em 1895. Em 1909 o nome passa a ser Escola de Agronomia e Veterinária e em 1926 acrescentase o nome de Eliseu Maciel. Em 1958 é inaugurado o prédio principal de uma nova sede, com mais de quinze mil $\mathrm{m}^{2}$, na época louvado como o maior edifício monobloco para o ensino de agronomia. Dois anos depois, a Escola compõe a Universidade Rural do Sul, que em 1967 é federalizada e em 1969 transformada em Universidade Federal de Pelotas (UFPel) ${ }^{113}$. A sede nova, no município de Capão do Leão, torna-se o Campus Capão do Leão (figura 35).

\footnotetext{
112 http://www.agronomia.ufba.br/historico.html

$113 \mathrm{http} / / /$ wp.ufpel.edu.br/faem/historico/
} 
No Estado de São Paulo, o atual campus da USP em Piracicaba foi idealizado por Luiz de Souza Queiroz, proprietário da fazenda que o abrigava e articulador para a fundação da escola agrícola e posterior escola superior. Em sua homenagem a unidade se chama Escola Superior Agrícola Luiz de Queiróz (ESALQ), e o campus também recebe seu nome. Em 1891, iniciou sua realização, com obras de adaptação na fazenda para transformá-la em um espaço adequado ao ensino. Entre as intervenções planejadas, destacava-se a construção de um prédio principal com quase cem metros de fachada frontal. O projeto foi desenhado por um arquiteto inglês (Alfred Hutchings), que nunca esteve no Brasil e que a bibliografia não registrou nenhum outro trabalho ${ }^{114}$. Desse prédio foram construídos apenas os alicerces. $O$ campus, no entanto, só foi sofrer um processo de planejamento em 1894/95, quando um professor belga de agronomia, Léon Morimont, foi contratado para criar um projeto pedagógico e um espaço adequado para esse projeto. Esse espaço foi projetado pelo Eng ${ }^{\circ}$ Francisco Henzler, funcionário da Diretoria de Obras Públicas da então presidência do Estado ${ }^{115}$. Alguns edifícios desse tempo ainda existem: como o antigo prédio de ensino de química e o prédio principal (inconcluso até 1907). Por alguns problemas práticos e políticos, a escola permaneceu praticamente sem funcionar até 1905, quando finalmente foi reaberta e as obras concluídas. Nesse ano, foi contratado o arquiteto paisagista (também de origem belga) Arséne Puttmans para realizar um projeto de integração do entorno dos prédios mais importantes, que resultou em um parque. Esse parque circundava o prédio principal (finalmente concluído), outras edificações e algumas hortas didáticas.

Esse histórico repleto de idas e vindas não chega a descaracterizar a unidade do conjunto, que foi tombado pelo CONDEPHAAT em $2006{ }^{116}$. O projeto de Arséne Puttmans (que também foi autor, por exemplo, da Praça da República e do parque do Museu Paulista na cidade de São Paulo), possui características tanto de jardim inglês quanto de jardim francês, com cuidadosa implantação dos maciços arbóreos, dos gramados e das áreas edificadas ${ }^{117}$. Na foto de 1907 estão retratados o prédio

\footnotetext{
114 PERECIN (2004). Pg. 114-115.

115 Idem, pg. 145-147. No entanto, outras fontes informam que o projetista foi o Eng ${ }^{\circ}$ José Van Humbeeck, do mesmo departamento. Ver http://www.labjor.unicamp.br/midiaciencia/article.php3?id_article=390.

116 Ver http://www.esalq.usp.br/noticia/detalhe.php?id=716 e LOURENÇO (2002).

117 Enquanto alguns trabalhos destacam as características de jardim inglês, como BARBIN, outros
} 
principal (projeto de 1895 aproveitando-se os alicerces do projeto de 1891), o sistema viário e uma das incipientes massas arbóreas. Esse projeto foi pouco alterado ao longo do tempo, com a exceção da demolição do bloco à esquerda do prédio principal (substituído por outro de maiores dimensões) e obviamente do crescimento das espécies arbóreas (figura 36).

Em 1910 um decreto do então Presidente da República definiu as bases do ensino superior de agronomia. Nesse mesmo decreto foi criada a Escola Superior de Agricultura e Medicina Veterinária, que durante alguns anos funcionou na cidade do Rio de Janeiro, próxima ao Maracanã. Fechada em 1916, foi reaberta em 1919 na cidade de Niterói. Em 1927 muda-se para a Praia Vermelha, próxima a outras unidades da Universidade do Brasil, porém sem juntar-se a ela. Na década de 30 o ensino é regulamentado e as escolas de agricultura e veterinária se dividem em duas.

Figura 36: O parque da ESALQ em construção (1907).

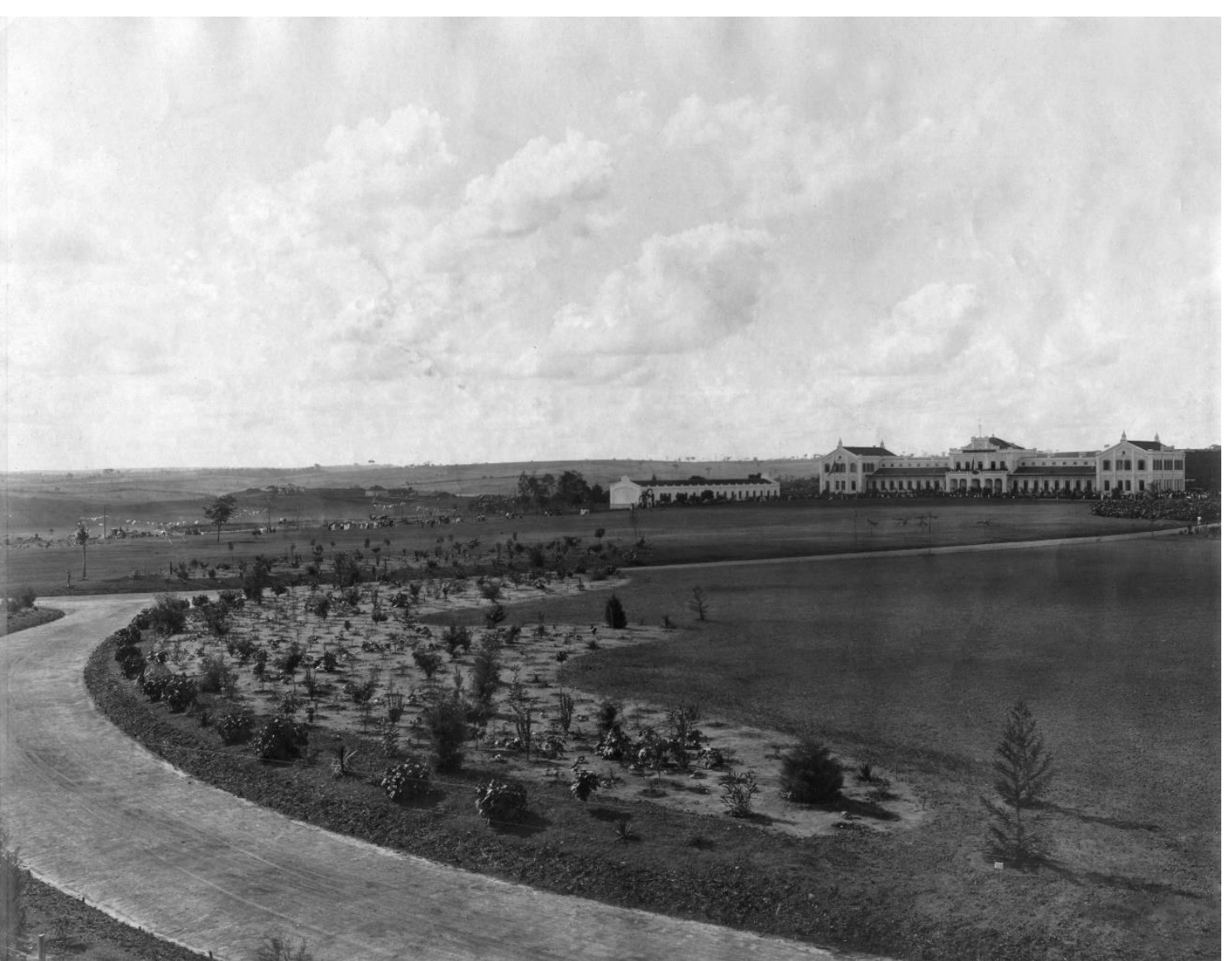

destacam as características de jardim francês, como PERECIN. Uma observação mais cuidadosa permitirá que assumamos a preponderância das características inglesas, como a paisagem com características de jardim natural, pouca linearidade (apenas a via de acesso à esquerda do edifício principal), visuais privilegiando a massa arbórea e a possibilidade de circular sem a visão de áreas edificadas. BARBIN (1999). 
Somente em 1943 ambas são transformadas em Universidade Rural - que daria origem à atual UFRRJ. Poucos anos depois a recém-organizada universidade passa a ocupar o Campus Seropédica, em uma antiga propriedade produtora de seda (e que dá nome à cidade: "lugar onde se fabrica seda"). Esse campus teve suas obras iniciadas em 1938, período em que Fernando Costa era o ministro da agricultura ${ }^{118}$.

Em Minas Gerais surge a outra instituição seminal de ensino superior na área de agricultura e veterinária no Brasil. A partir do Decreto Estadual 6.053 de 30 de março de 1922 foi criada a Escola Superior de Agricultura e Veterinária (ESAV), efetivamente instalada em 1926, com cursos superiores a partir de 1928. Em 1948 tornou-se Universidade Rural do Estado de Minas Gerais e assim foi federalizada em 1969, quando foi renomeada para Universidade Federal de Viçosa (UFV) ${ }^{119}$. Situada em um campus com características urbanísticas belas artes, marcada por um eixo monumental ladeado pelas construções principais e lagos (posteriormente construídos), implantado em um vale encrustado nas montanhas das serras vizinhas da cidade (figura 37). Esse campus continua em pleno crescimento, com o eixo preservado, bem como os jardins frontais aos prédios históricos.

Figura 37: Universidade Rural do Estado de Minas Gerais, atual UFV, em foto da década de 1920.

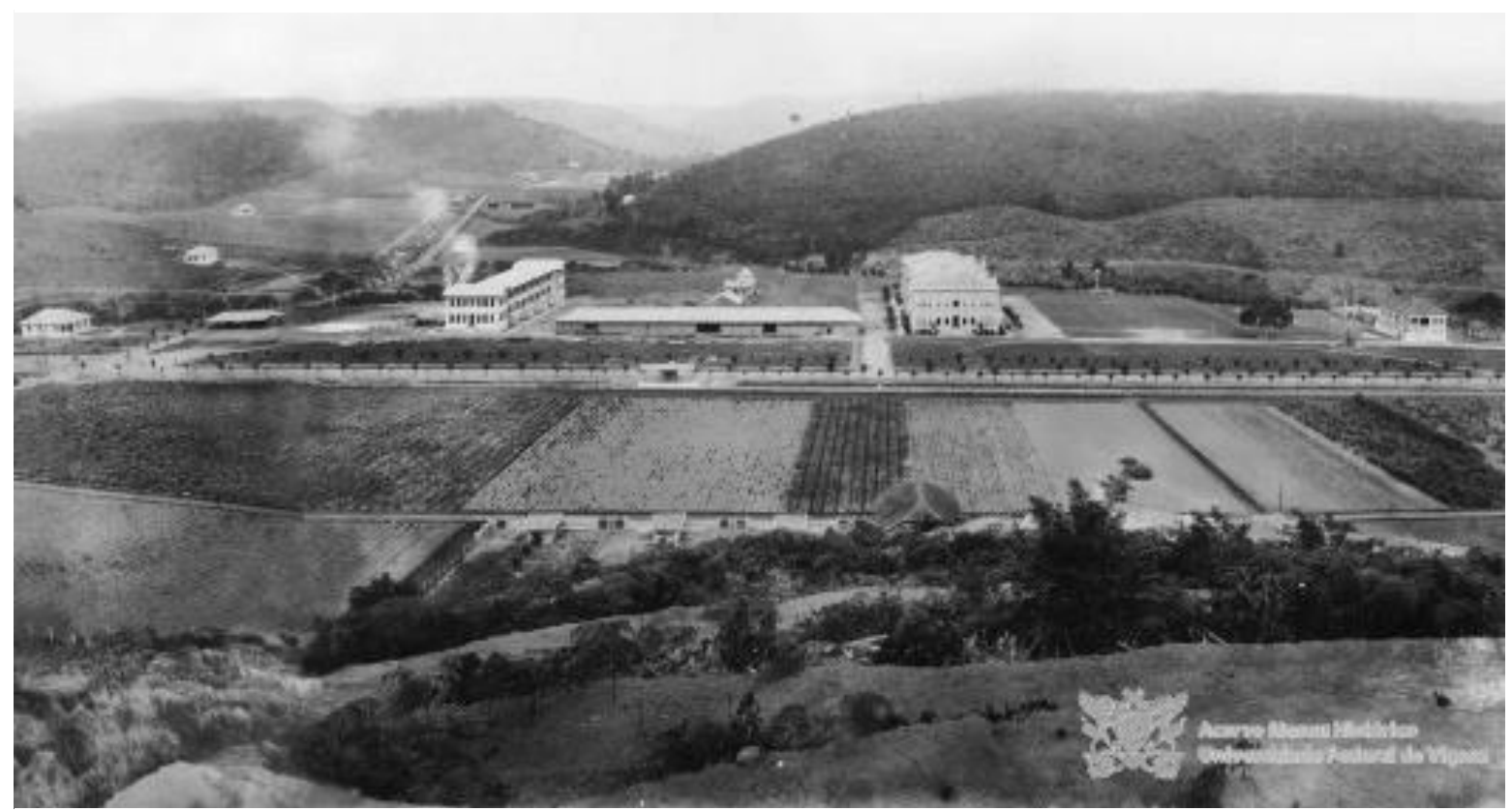

Fonte: http://www.vitruvius.com.br/revistas/read/arquitextos/11.132/3881

\footnotetext{
118 http://r1.ufrrj.br/centrodememoria/ufrrj_historia.php

119 http://www.ufv.br/
} 
Outra escola que remonta às origens do ensino superior em âmbito rural no país é a antiga Escola de Agronomia da Parahyba, situada no município de Areia. Criada por um decreto estadual em 1934, a instalação se deu em 1936, sendo o curso de nível superior mais antigo do estado. Funcionou concomitantemente com cursos práticos e técnicos até 1971. Desde sua fundação instalada no Campus Areia, ocupa um antigo engenho (Engenho Várzea). Foi federalizada em 1951 e integrada à Universidade Federal da Paraíba desde 1968. Dez anos depois torna-se o Centro de Ciências Agrárias, ampliando a oferta e a diversidade de cursos ${ }^{120}$.

Por fim, há o caso da atual Universidade Federal da Amazônia (UFRA), situada em Belém do Pará. Sua existência remonta ao antigo Instituto Agronômico do Norte, criado por um decreto de Fernando Costa quando Ministro da Agricultura, em 4 de maio de $1939{ }^{121}$. Sua instalação concluiu-se nos anos 40, a partir de projeto aparentemente de Ângelo Murgel. Em 1945 é implantada a Escola de Agronomia da Amazônia, que é renomeada em 1972 para Faculdade de Ciências Agrárias do Pará (FCAP) e torna-se Universidade apenas em 2002.

Em São Paulo, algum tempo depois da formação do "Grupo de Estado", ganham relevância algumas práticas de valorização do trabalho do campo, que tinha por objetivo implantar a educação para um novo camponês, um camponês integrado às questões de seu tempo. A crítica ao personagem "Jeca Tatu", que envergonhava a sociedade do interior paulista, estava na base desse ideal ${ }^{122}$.

Esse "idealismo construtor" ${ }^{123}$ ensejou a criação das Escolas Práticas de Agricultura, de Institutos Agronômicos Nacionais e a própria Escola Nacional de Agricultura (atual Universidade Federal Rural do Rio de Janeiro, a UFRRJ). Encabeçando essas ações estava Fernando Costa, que em cada cargo que ocupou realizou obras e realizações ${ }^{124}$. Como Ministro da Agricultura, fundou o Instituto Nacional de Agricultura em Belém do Pará e deixou em obras outro Instituto em

\footnotetext{
120 http://www.cca.ufpb.br/

121 COSTA (1939), pg.

122 TELES e IOKOI (2005), pg. 64.

123 COSTA (1930). Título de uma das primeiras publicações de Fernando Costa, que em preâmbulo assinado por "amigos e apoiadores" tenta definir em duas palavras a prática política do personagem.

124 Consultamos a bibliografia de Fernando Costa, que consta ao final desta Dissertação, na qual há um livro para cada cargo ocupado, apresentando suas realizações.
} 
Pernambuco, além de adquirir o local para a implantação da Escola Nacional de Agricultura e articular sua construção. Como Interventor do Estado, quase imediatamente inicia a articulação para a criação das Escolas Práticas de Agricultura. 



\section{CAPÍTULO 2}

\section{Modernidade no campo: uma escola para transformar o interior}

Neste capítulo o tema principal é a fundação da Escola Prática de Agricultura em Pirassununga, por meio de uma abordagem analítica do território, tanto a partir de documentos e dados, como análises visuais e comparações com outros territórios universitários. Apresentamos e discutimos o projeto original, as condições geográficas, técnicas e pedagógicas da Escola Prática de Agricultura. Apresentamos também os resultados da pesquisa realizada junto aos acervos do NE/SAA e da CPOS. A autoria do projeto pode ser dedicada aos profissionais da empresa Sociedade Construtora Brasileira S/A, que foi responsável pela construção da Escola Prática de Agricultura. Conforme exposto na Introdução, essa suposição se fundamenta na observação dos desenhos do projeto executivo. Aqueles que foram efetivamente construídos possuem carimbos da empresa. As assinaturas não são de profissionais das secretarias, portanto deduzimos que são assinaturas de funcionários da empresa ou de escritórios contratados por ela. Infelizmente não localizamos os acervos da empresa, que não existe mais.

Ainda neste capítulo se interpreta a relação entre a antiga Escola Prática de Agricultura com a Pirassununga da época e se analisa o trabalho realizado nas gestões de Fernando Costa em diferentes instituições. Este capítulo encerra, portanto, a maior parte da pesquisa documental realizada. Os textos apresentados tentam interpretar esses documentos originais da implantação da antiga Escola Prática de Agricultura, realização de dimensões e esforços superlativos para a época. No centro dessa discussão está a personalidade de Fernando Costa, que, desde dezembro de 2015, dá nome ao campus da USP em Pirassununga.

\subsection{Fernando Costa e o projeto de modernização do campo brasileiro}

Fernando Costa iniciou sua carreira política em Pirassununga, cidade que adotou após sua formatura em Engenharia Agronômica pela ESALQ e o casamento com uma pirassununguense, Anita Costa. Ali foi Prefeito, aos vinte e seis anos de 
idade. Teve uma gestão memorável, levando para a cidade a Escola Normal, que seria destinada a alguma cidade maior. Sua fama cresce pela região, como político promissor e bastante eficaz ${ }^{125}$.

Fernando Costa foi afiliado ao Partido Republicano Paulista, depois de sua candidatura como independente na primeira eleição que venceu para deputado estadual. Neste partido alçou cargos importantes, sendo indicado Secretário pelo Presidente do Estado, Júlio Prestes. Durante a Revolução Constitucionalista apoiou o Estado de São Paulo, depois mudando rapidamente de campo político e tornando-se apoiador getulista. Em seus discursos defendia bravamente o Presidente Getúlio Vargas, que o tornou ministro e depois interventor no Estado. Quando houve a reorganização do sistema político, depois do segundo período ditatorial de Vargas (1937-1945), Fernando Costa ajuda na organização do PSD, que abrigava apoiadores do governo varguista e onde era candidato natural ao Governo do Estado de São Paulo e, quiçá, à Presidência da Nação ${ }^{126}$. Em todos os períodos de sua carreira político foi tido como um técnico, conhecedor de agropecuária e grande realizador. $O$ resumo de sua lista de realizações é realmente impressionante: em Pirassununga praticamente todas as instituições públicas presentes são decurso de sua ação; os Institutos Nacionais de Agricultura, hoje transformados em Universidades Rurais; a Escola Nacional de Agricultura, atual UFRRJ; o Parque da Água Branca e o Parque da Água Funda, em São Paulo; o Instituto Biológico; inaugurou postos zootécnicos e estações experimentais; a campanha do gasogênio; a descoberta de petróleo no Brasil (na Bahia); entre várias outras ações, principalmente ligadas à agricultura ${ }^{127}$.

Ainda antes de seguir sua carreira política fora das fronteiras municipais de Pirassununga, profere um histórico discurso na formatura dos professorandos na Escola Normal da cidade, obra que ele próprio concluiu. Nesse discurso ressalta a necessidade do desenvolvimento de um modelo de educação rural no país. Pede aos formandos que "assentem sua tenda de trabalho no meio da população rural, pois esta é a que mais sofre e que mais necessita de vosso saber" ${ }^{128}$.

\footnotetext{
125 DEIP (1943), pg. 6.

126 Vìdeo "O Idealista Realizador" (1994) Prefeitura Municipal de Pirassununga". DEIP (1943). Fernando Costa e sua vida pública.

$127 \mathrm{Na}$ bibliografia de Fernando Costa há listas de realizações em publicações que resumem o seu tempo ocupando cada cargo público.
}

128 COSTA (1931), pg. 373. 
Em julho de 1927, indicado pelo Presidente do Estado de São Paulo, Júlio Prestes, Fernando Costa assume a então Secretaria da Agricultura, Comércio e Obras Públicas. Essa pasta lidava com enorme diversidade de temas, concentrando diversos serviços públicos. Além da agricultura (com várias ramificações institucionais), do comércio (idem) e das obras públicas, também se responsabilizava pelo sistema de transporte intermunicipal, pelas linhas férreas, pelo serviço de águas e esgotos da capital e da cidade de Santos, pelo setor de obras de saneamento do Estado, entre outras atividades ${ }^{129}$.

Sua primeira missão foi realizar uma reforma administrativa na Secretaria, dividindo-a em duas. A nova Secretaria de Estado dos Negócios da Agricultura, Indústria e Comércio herdou a maior parte das atividades e do poder político anterior, enquanto a desmembrada Secretaria de Estado dos Negócios de Viação e Obras Públicas se responsabilizaria por essas atividades e pelos serviços de águas e esgotos. A "Reforma Fernando Costa" ocorreu em setembro de 1927, apenas dois meses após a posse de Fernando Costa ${ }^{130}$.

Portanto nosso personagem, muito eficaz em seus propósitos, seguiria detendo o poder administrativo sobre os setores primário, secundário e terciário, enquanto delegava a infraestrutura para outra unidade administrativa. Entre as instituições que subordinavam-se à Secretaria, estavam o Instituto Agronômico (que até hoje é um órgão de pesquisa) e a Escola Superior de Agricultura Luiz de Queiróz, atualmente componente da USP ${ }^{131}$. Em 1931 a Escola de Medicina Veterinária que havia no Instituto de Veterinária é reaberta e consolidada com um curso de nível superior de quatro anos, por determinação direta do Secretário, e depois transferida para o Parque Água Branca.

Também em 1927, em seu primeiro ano como Secretário, Fernando Costa incentiva a publicação do Decreto que cria o Conselho Superior do Ensino de Agricultura do Estado, presidido pelo próprio secretário e composto pelos diversos diretores subordinados à Secretaria. Esse Conselho definiria a regulação do ensino superior e fomentaria a criação de vários níveis de educação agrária, ora introduzindo

\footnotetext{
129 MARTINS (1991), pg. 203-205.

130 Id., pg. 205.

131 Ibid., pg. 206.
} 
conceitos e disciplinas nos currículos das escolas existentes, ora criando escolas específicas para determinados nichos ${ }^{132}$.

Entre 1929 e 1932 dois grandes eventos que modificam a história do país causam impacto sem precedentes na agricultura paulista. A crise econômica internacional, seguida da crise política nacional e a tomada de poder por Getúlio Vargas, aceleram processos históricos que a política e a economia do período anterior ainda freavam. Muito resumidamente, podemos afirmar que os principais processos foram a diversificação produtiva no campo e o incentivo governamental para o desenvolvimento da indústria, que já vinha se instalando na capital do Estado ${ }^{133}$. O primeiro, principalmente em função da crise do café, cujas sacas chegaram a ser queimadas para controle dos preços. O segundo, iniciado em uma situação de pujança econômica, agora dependia de influência governamental para continuar crescente. Em pleno curso desses processos, Fernando Costa sai da Secretaria de Agricultura, no final de 1930.

Quase sete anos depois, Fernando Costa assumiria o Ministério da Agricultura, após ter ocupado a presidência do Conselho Nacional do Café, indicado pelo Presidente Getúlio Vargas. Sua passagem do Partido Republicano Paulista (PRP) para o governo varguista, seu maior adversário, foi bastante rápida: a admiração de Fernando Costa por Getúlio Vargas aparece em vários de seus discursos ${ }^{134}$. $\mathrm{Na}$ gestão desse ministério, voltaria a ter imensa influência sobre a agricultura paulista, já que o Estado Novo varguista preconizada um nacionalismo centralizador, demarcado pelo poder excessivo na figura do próprio Getúlio Vargas e em cada um de seus ministros ${ }^{135}$.

Em 1939, a Seção de Engenharia Rural torna-se Diretoria de Engenharia Rural 136. Essa Diretoria de Engenharia Rural é que responsabilizar-se-ia pelos projetos da maioria das Escolas Práticas de Agricultura.

Em 03 de junho de 1941, Fernando Costa deixa o Ministério de Agricultura, e

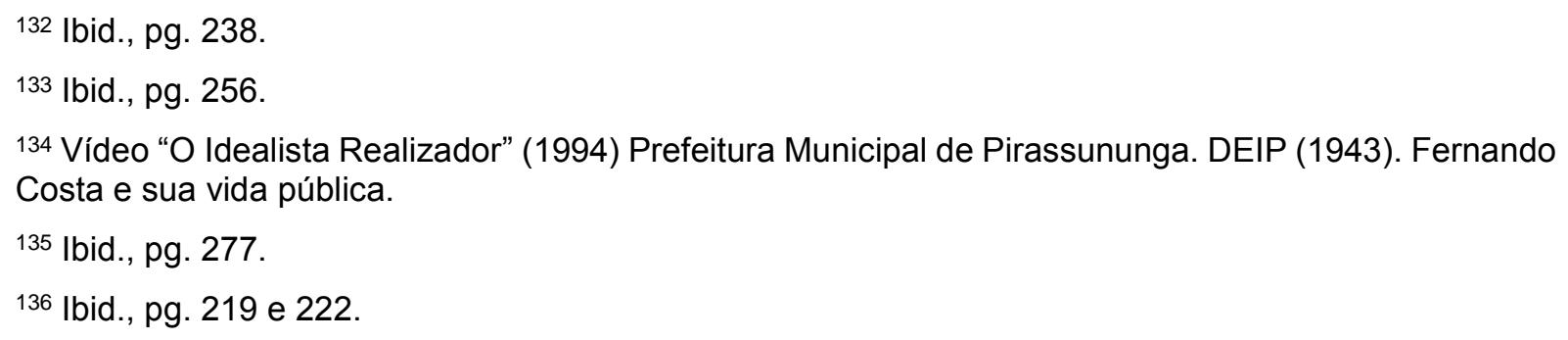


no dia seguinte assume o Governo do Estado de São Paulo, como Interventor Federal. Nesse período assinou o Decreto Lei Estadual 13.855 de 29 de fevereiro de 1944, que transformou a Universidade de São Paulo em autarquia, portanto adquirindo efetiva autonomia ${ }^{137}$. Em sua gestão no governo, diversas iniciativas foram tomadas no campo, priorizado como espaço preferencial do desenvolvimento do Estado. Para justificar sua priorização, os departamentos de estatísticas produziram planilhas que comprovavam que o desenvolvimento do Estado tinha em sua base a atividade primária ${ }^{138}$.

Nesse período são planejadas e construídas as escolas práticas agrícolas. Destinavam-se "à formação do produtor rural e para atuarem como centros de difusão de conhecimentos fundamentais da agricultura racional e aperfeiçoamento dos processos de indústria agrícola regional" ${ }^{139}$. Melhor explicado na seguinte citação do Relatório de Agricultura de 1945, documento redigido anualmente pela Secretaria:

\footnotetext{
"Para completar a constituição dos órgãos destinados ao aperfeiçoamento e propulsão das atividades de vida agrícola do Estado, juntando aos serviços de experimentação e fomento mais um meio de ação essencial para a consecução daquele propósito, foi planejado e está sendo posto em execução um grande plano de ensino prático de agricultura. Nessa transformação, representa papel capital o elemento rural, constituído pelo trabalhador do campo, o qual deve receber uma instrução objetiva, que o ponha à altura da situação, para não ter de se lamentar a ausência crescente de operários aptos a executar os mais rudimentares trabalhos da terra, como se verifica ainda entre nós, em virtude da falta de escolas práticas. Sentindo que, ao esforço particular dos lavradores paulistas, cujas iniciativas e operosidade são bastante conhecidas, deve juntar-se a ação oficial, foi planejada a criação de escolas práticas de agricultura". ${ }^{140}$
}

Os ensinamentos se concentravam nas áreas de agricultura geral, agricultura especializada, exploração racional, indústrias rurais, educação sanitária e alimentação racional. Em 1942 se iniciaram as construções das primeiras: Ribeirão Preto, Bauru, Pirassununga, Guaratinguetá e Itapetininga. A seguir, Marília, São José do Rio Preto, Presidente Prudente, Araçatuba e Amparo. Depois, em 1946, seria incorporada a escola de Jaboticabal.

\footnotetext{
137 MOTOYAMA (2006), pg. 29.

138 Ibid., pgs 272-273.

139 Ibid., pg. 299.

140 SAAESP (1945).
} 
Comprovando a priorização para as iniciativas de desenvolvimento no campo, foi criada em 1942 a Diretoria de Ensino Agrícola, sob o comando da Secretaria de Agricultura. A Diretoria também assumiria as funções do antigo Conselho Superior de Ensino de Agricultura do Estado, orientando, dirigindo e fiscalizando o ensino agrário no Estado ${ }^{141}$.

É interessante notar que, em pleno desenrolar da segunda grande guerra mundial, a agricultura paulista permanecia como um dos itens prioritários para o desenvolvimento nacional, a despeito da enorme importância adquirida pela indústria. $\mathrm{E}$, dentro desse contexto, a educação do homem do campo era item presente, relevante, em cada relatório anual. No Relatório da Agricultura de 1943, o Secretário frisava seis itens nos quais se calcava o trabalho da Secretaria. O primeiro relativo à assistência técnica, o segundo relativo ao fomento da produção, o terceiro e o quarto relativos à vigilância sanitária e a defesa do substrato, o quinto relativo à formação educacional e o sexto propondo o campo como uma alternativa de vida - sendo lucrativo e convidativo para o estabelecimento das famílias ${ }^{142}$. Percebe-se a concatenação entre os itens, o papel promotor de desenvolvimento do Estado e uma política muito bem delineada, que - concordando-se ou não - mantinha uma coerência entre discurso e prática. No ano seguinte o relatório encerra uma discussão sobre a dicotomia entre vida nas cidades e no campo, ponderando a existência de uma economia rural, uma sociologia rural e um direito rural, em contraponto à economia industrial, a sociologia urbana e o direito comum, civil, industrial ou comercial $^{143}$.

Uma análise possível é sobre a relação entre o projeto de desenvolvimento e modernização do país preconizado por Fernando Costa, em especial no seu período varguista, e a relação com as construtoras. Nos governos do PRP em São Paulo há uma grande profusão de obras públicas, em especial as obras de infraestrutura, que no projeto político daquele grupo seriam a base para o desenvolvimento do Estado. Para a realização dessas obras era importante que existissem empreiteiras fortes, sólidas financeiramente, com grande poder de mobilização, caixa para a compra de máquinas e contratação de funcionários. Porém essa magnitude também dava às

\footnotetext{
141 lbid., pgs 285.

142 SAAESP (1943).

143 SAAESP (1944).
} 
empresas um poder significativo para a decisão da realização das obras. Fernando Costa não escapava à regra: seu perfil "idealista realizador" é típico dessa forma de fazer política. Contava com o apoio das empreiteiras para a realização da grande quantidade de obras de vulto que imaginou e empreendeu. A relação com Roberto Simonsen, de mesma trajetória política e sócio de construtoras, foi determinante para a realização da Escola Prática de Agricultura em Pirassununga. Finalmente, em sua biografia oficial, há uma afirmação que Fernando Costa, caso se ausentasse de seus cargos públicos, teria que procurar um emprego, visto não ser uma pessoa com posses (figura 38$)^{144}$.

Fernando Costa parece ter suas predileções arquitetônicas. Em sua publicação sobre as realizações como Ministro da Agricultura, inicia a longa lista explicando sobre as edificações (o que já denota a importância que dava a esse mérito). Ao descrever a Escola Nacional de Agricultura, a futura UFRRJ, afirma que o complexo arquitetônico, "obra grandiosa, já pelas instalações projetadas tendo em vista os progressos do ensino agronômico, já pelo aspecto arquitetônico" ${ }^{145}$. Do contato com Ângelo Murgel até suas últimas realizações no Governo do Estado de São Paulo, em especial nas obras que considerava mais importantes, encontramos a arquitetura neocolonial. Há, inclusive, uma resolução oficial que determina que todas as construções devem ser erigidas "rigorosamente de acordo com o estilo colonial brasileiro" ${ }^{146}$.

Mas nem todas as obras da Secretaria de Agricultura (justamente a área de especialidade de Fernando Costa) adotaram o estilo neocolonial. Em publicação de maio de 1944 na revista Acrópole, o Departamento de

Figura 38: Busto de Fernando Costa no prédio principal da USP em Pirassununga.

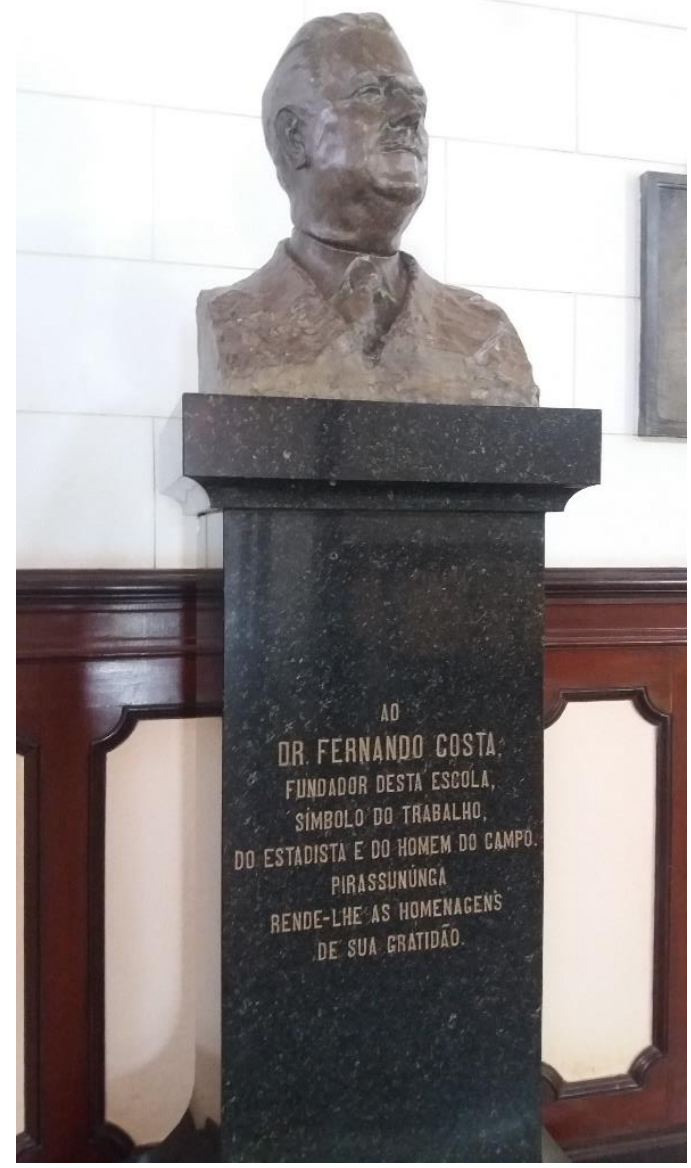

Fonte: autoria própria.

\footnotetext{
144 DEIP (1943), pg. 9.

145 COSTA (1941). Pg. 17.

146 RITTER (1943), pg. 14.
} 
Engenharia Rural apresentava algumas de suas obras: o Clube de Campo de Pirassununga, dentro da Escola Prática de Agricultura; o Pavilhão da Engenharia da ESALQ; a Casa do Fazendeiro no Parque da Água Branca em São Paulo e um Parque para Aves no Departamento de Produção Animal da Secretaria, em São Paulo. Apesar do destaque dado ao projeto em Pirassununga, as demais construções são art-decó, como se pode observar na imagem do Pavilhão de Engenharia e "modernas", conforme a classificação dada pelo artigo ${ }^{147}$.

A arquitetura neocolonial adotada nas obras educacionais sob a gestão de Fernando Costa inclui o instituto do Centro Nacional de Pesquisas Agronômicas, depois Universidade Federal Rural da Amazônia (UFRA), em Belém; a Escola Nacional de Agronomia, depois UFRRJ e as Escolas Práticas de Agricultura no Estado de São Paulo, estas últimas em seu período como Interventor.

Mas qual é a arquitetura neocolonial que nos referimos? Maria Lúcia Bressan Pinheiro explica que se trata de um movimento paralelo ao ecletismo e algumas vezes confundido a ele, já que possui um "caráter de livre criação, a combinar elementos suposta ou erroneamente oriundos da arquitetura brasileira do período colonial com cânones ecléticos de composição" ${ }^{148}$. Já Lauro Cavalcanti invoca José Marianno Filho para descrever o neocolonial, que afirma que o estilo não é uma "homenagem fetichista ao passado", mas sim um "retorno ao bom senso", já que resolve problemas técnicos de adequação ao meio e ao clima, de acordo com a prática secular e tem um vínculo direto com a estética própria da jovem nação ${ }^{149}$. Porém estabelece que os defensores do neocolonial pensavam no "pretérito construtivo brasileiro muito mais como colecionadores de borboletas em terreno fantasioso do que nos moldes de um resgate estrutural que estabelecesse uma doutrina adaptável às novas exigências impostas pelos impulsos da industrialização" ${ }^{150}$. Finalmente, há a influência de Ricardo Severo, arquiteto português que fundia a tradição lusitana com a colonial brasileira, afirmando que tais tradições guardavam uma mesma origem e aproximava as propostas estéticas. A arquitetura neocolonial era uma proposta de arquitetura

\footnotetext{
147 ACRÓPOLE (1944). Maio, pg 6-9. Realizações da Divisão de Engenharia Rural da Secretaria de Agricultura de São Paulo.

148 PINHEIRO (1997), pg. 64 apud BOGHOSIAN (TFG), pg. 19.

149 CAVALCANTI (2006), pgs. 109-111.

150 Id., pg. 217.
} 
nacional, que, em tese, superaria o neoclássico (apoiado pelos acadêmicos) e o eclético (realizado por profissionais não arquitetos ou engenheiros) em um contexto modernizante. Seu adversário era o modernismo, uma proposta universalista. Como sabemos, vencerá a posição modernista, por uma série de fatores explicitados por Lauro Cavalcanti ${ }^{151}$.

Sem a intenção de emitir valor sobre a proposta neocolonial, observamos que a arquitetura das Escolas Práticas de Agricultura (e das demais obras neocoloniais construídas sob a pasta de Fernando Costa) são simplificações das soluções neocoloniais tipicamente defendidas por José Marianno Filho e Ricardo Severo, mais singelas e funcionais, ainda que nitidamente afiliadas a essa proposta. Suas fachadas, expressão mais aparente da afiliação ao neocolonial, são na maioria das vezes simples, porém adotam elementos como volutas, óculos, balaústres, possuem telhamentos cerâmicos em capa-canal com caimento frontal, beirais generosos, azulejarias, arcadas, etc. Os interiores, ao contrário, possuem extrema funcionalidade. Com poucas exceções, os prédios abrigam funções técnicas ou muito específicas e funcionam de maneira racional, sem a presença de qualquer ornamento ou elemento que não se faça necessário.

\subsection{O projeto da Escola Prática de Agricultura em Pirassununga}

Pouquíssimos trabalhos foram realizados sobre a história e o desenvolvimento do atual Campus Fernando Costa da Universidade de São Paulo. O principal deles foi a pesquisa coordenada pela professora Zilda Márcia Grícoli lokoi, com a coautoria da historiadora e bolsista Teresa Cristina Teles, que resultou na publicação do livro "Campus de Pirassununga da USP: Memória e história". Essa pesquisa tem em sua base os documentos guardados por décadas pelo professor Noé Massoti, que faleceu antes da publicação da edição. Seu principal incentivador foi o professor Ricardo de Albuquerque, ex-prefeito do campus e também um grande colaborador para o desenvolvimento desta pesquisa. O trabalho desenvolvido pela professora Zilda e pela pesquisadora Teresa Cristina tem como metodologias principais o levantamento e

151 lbid., pgs. 225-232. 
interpretação do material do professor Noé e o registro de depoimentos, portanto a "história oral" fundamenta o texto.

Há também os trabalhos de Mariana Boghosian Al Assal, que aprofundou seus estudos a partir do Trabalho Final de Graduação (TFG), com o título "Escola Prática de Agricultura Fernando Costa: Patrimônio da USP", até a Dissertação de Mestrado,

Figura 39: Condições atuais do acervo do NE/SAA.
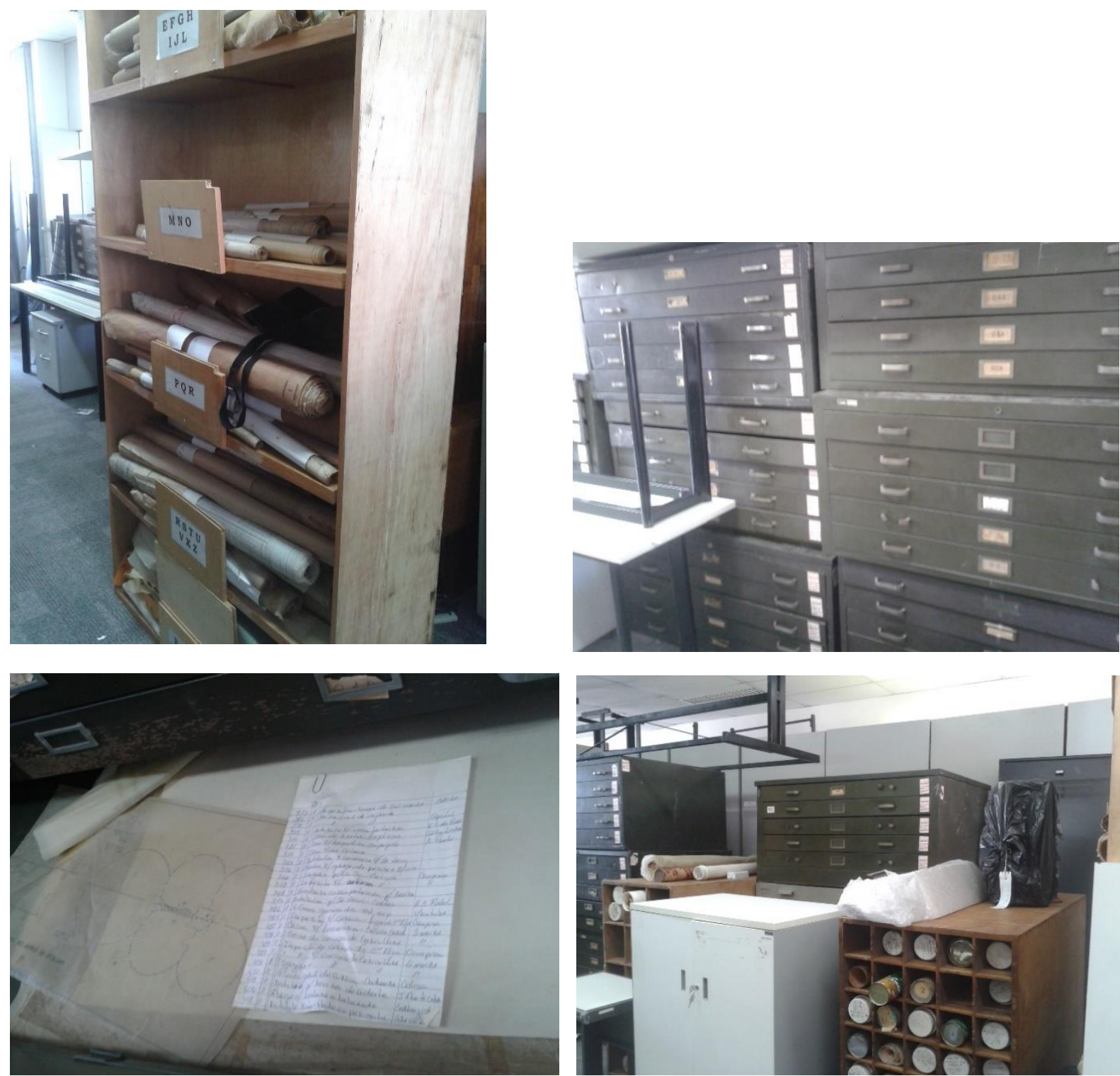

Fonte: autoria própria.

com o título "Arquitetura, identidade nacional e projetos políticos na ditadura varguista - as Escolas Práticas de Agricultura do Estado de São Paulo", sendo que neste trabalho a abordagem é mais ampla, ainda que centralizada em Pirassununga. Em seu TFG, Mariana registrou e inventariou os edifícios existentes que foram construídos 
antes da inauguração e em seus primeiros anos, no que podemos classificar como "projeto original do campus", com a função de escola prática agrícola. Alguns dos registros apresentados nesse trabalho devem ser únicos, já que uma parte do material original, antes arquivado no NE/SAA, não foi encontrado nas últimas visitas realizadas no local (no primeiro semestre de 2016).

Cabe mencionar que o arquivo do NE/SAA foi deslocado algumas vezes nos últimos anos: da antiga sede no Parque Fontes do Ipiranga para a atual, no antigo Hotel Esplanada (edifício que depois foi sede das empresas Votorantim e agora é ocupado por Secretarias do Estado). Nesse endereço atual, já mudou de lugar duas vezes. As condições atuais do arquivo são preocupantes: papeis vegetais estão enrolados inadequadamente, ora acondicionados em "tubos" plásticos, ora depositados sobre estantes de madeira (figura 39). Foram encontrados alguns desenhos originais dos projetos da Escola Prática de Agricultura nesse arquivo, repetindo o caminho trilhado por Mariana Boghossian em seu TFG e sua pesquisa de mestrado.

Além dos arquivos do NE/SAA, foram consultados os arquivos da CPOS, herdeira da antiga SVOP, a fim de acessar os projetos originais do campus. Ali estão alguns projetos que foram realizados pela equipe própria da SVOP e nenhum desenho originado na Secretaria de Agricultura ou carimbado pela empresa Sociedade Construtora Brasileira S/A. Esses projetos de edifícios, nem sempre construídos, são datados de período posterior à inauguração da Escola Prática de Agricultura (como na figura 38). Essa constatação permite afirmarmos a responsabilidade efetiva da Secretaria de Agricultura na construção do espaço original e o compartilhamento da responsabilidade em sua manutenção posterior.

No entanto, encontramos alguns estudos de data anterior ao decreto de fundação das Escolas Práticas de Agricultura, que provavelmente fundamentaram ou influenciaram o projeto efetivamente construído (figura 40). 
Um dos objetivos específicos da pesquisa dizia respeito a identificação da autoria do projeto. Analisamos, então, os carimbos dos projetos encontrados. Solicitamos ao Departamento de Recursos Humanos da SAA uma lista dos profissionais que trabalharam nos anos 40 na Secretaria, mais especificamente profissionais ligados à área da construção e projeto, como engenheiros, arquitetos e

Figura 40: Carimbo de projeto realizado pela Diretoria de Obras Públicas, modificando o ginásio de esportes da Escola Prática de Agricultura de Pirassununga.

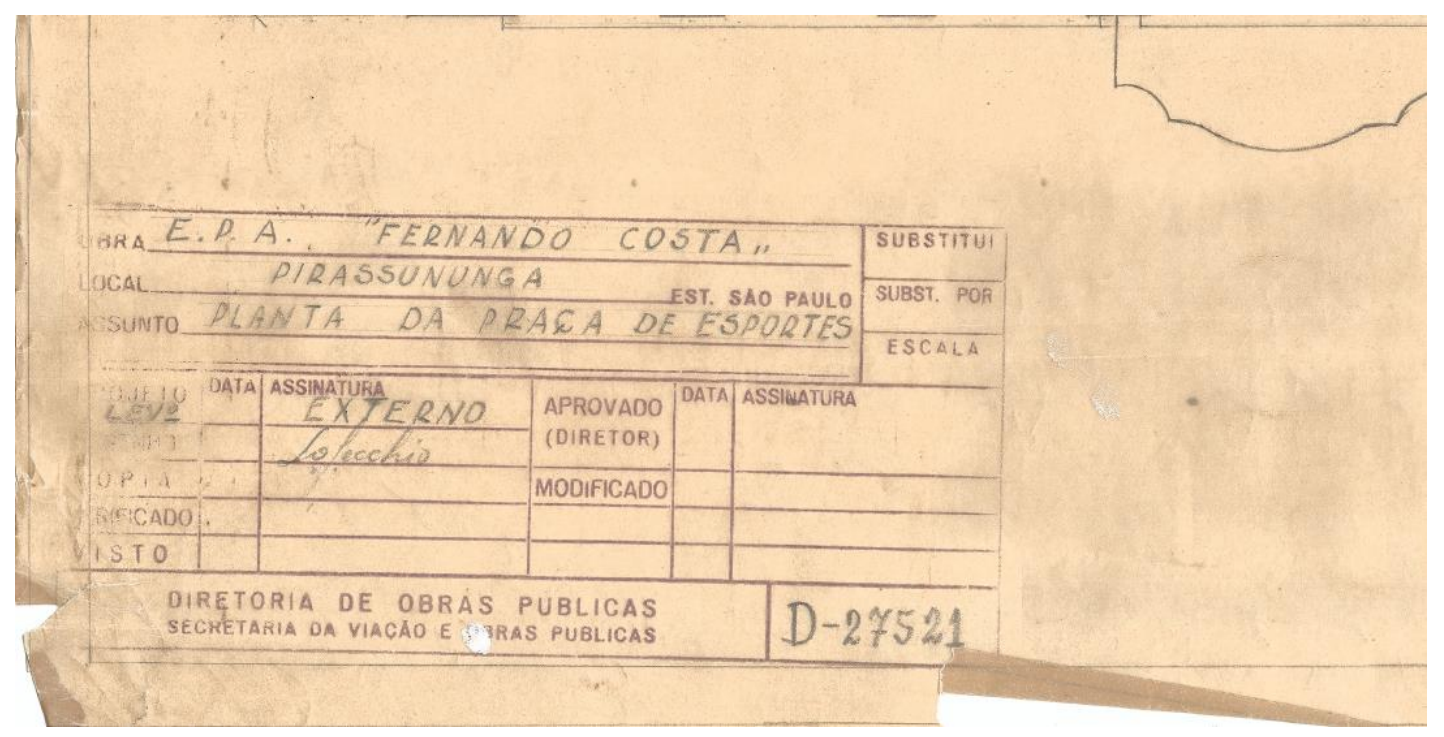

Fonte: acervo da CPOS (escaneado pelo autor).

Figura 41: Projeto anterior a construção da Escola Prática de Agricultura, assinado pela antiga Divisão de Engenharia Rural, atual NE/SAA.

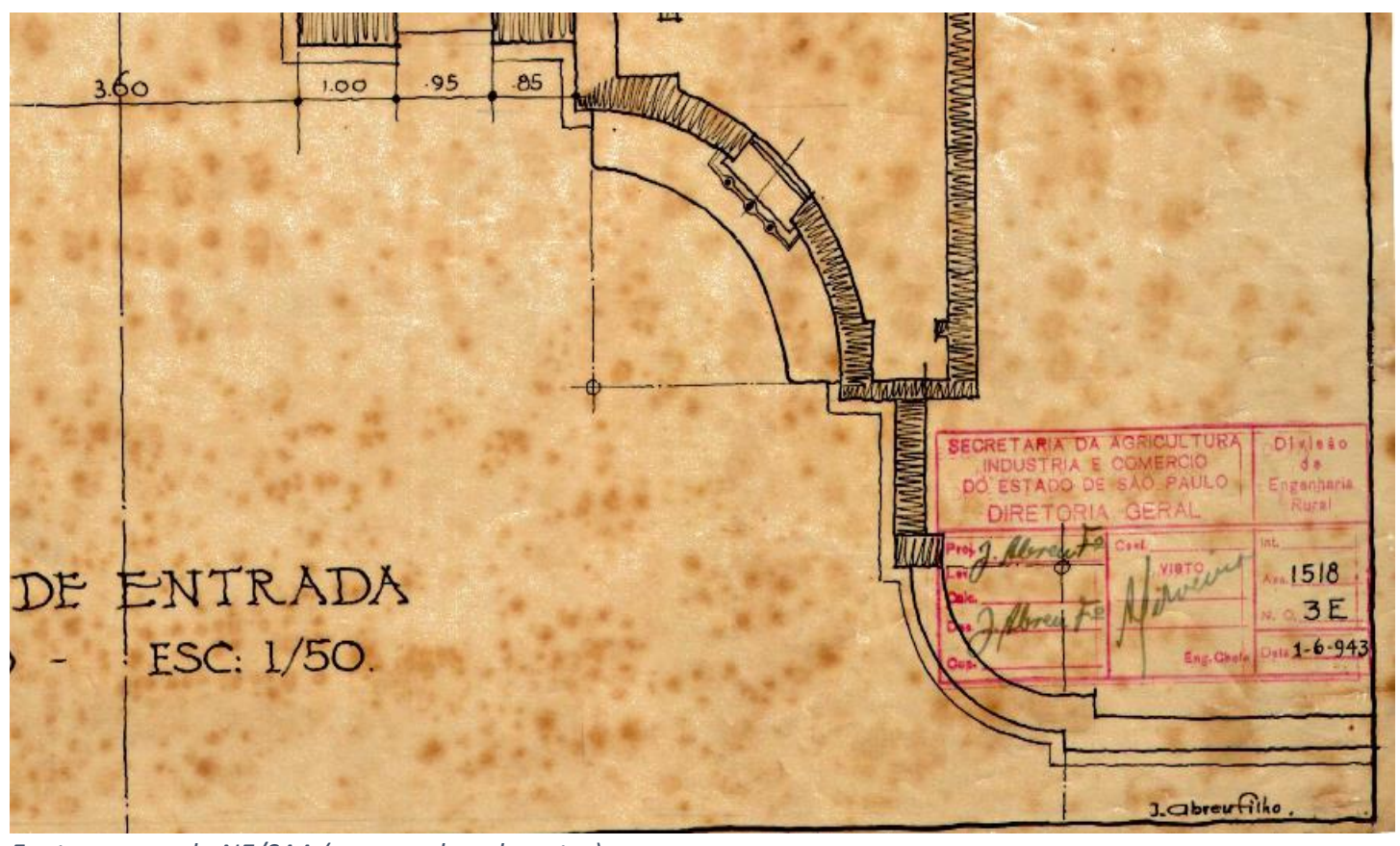

Fonte: acervo do NE/SAA (escaneado pelo autor). 
desenhistas ${ }^{152}$. A primeira constatação é de que não havia nenhum funcionário arquiteto nesse período, apenas engenheiros e desenhistas. Segundo, que comparando as assinaturas com os nomes dos profissionais listados, não foi encontrada praticamente nenhuma coincidência. Apenas encontramos possibilidade de relação em alguns poucos desenhos, anteriores ao Decreto de criação das Escolas, que representam projetos diferentes dos efetivamente construídos (como na figura 41).

Os desenhos encontrados que se referem aos edifícios efetivamente construídos possuem carimbos apenas da Sociedade Construtora Brasileira S/A ou carimbos da empresa e da também da SAA (figura 42). Foi procurado, então, o acervo da empresa. Constatamos que a empresa não existe mais. Foram realizadas buscas

Figura 42: Exemplos de carimbos de projetos efetivamente construídos (todos com o registro da Sociedade Construtora Brasileira).
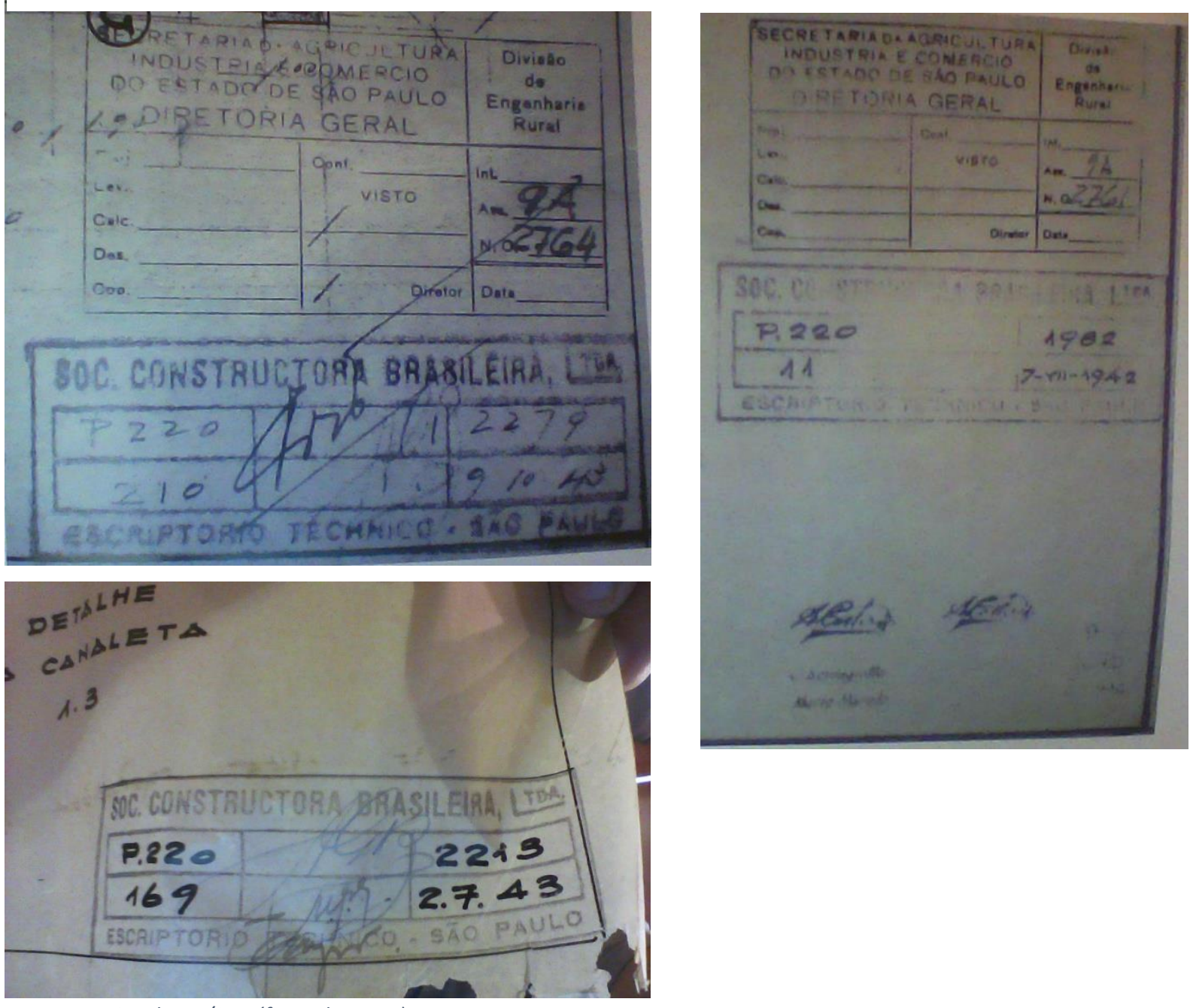

Fonte: arquivo do NE/SAA (fotos do autor).

152 Ver anexo 1. 
no Instituto de Engenharia (IE) e no Conselho Regional de Engenharia e Agronomia de São Paulo (CREA-SP) ${ }^{153}$. Outras buscas infrutíferas foram realizadas na cidade de Santos, onde a empresa era sediada, e no Arquivo do Estado. Infelizmente, é um caminho que deixamos em aberto.

Sabemos que as Escolas Práticas de Agricultura foram criadas, projetadas, construídas e inauguradas em períodos distintos durante a gestão de Fernando Costa na Secretaria da Agricultura ou logo após esse período, provavelmente sob sua influência. A primeira Escola Prática de Agricultura, em Jaboticabal, com o nome José Bonifácio, foi projetada em 1940 pelo Departamento de Engenharia Rural da Secretaria de Agricultura ${ }^{154}$. As demais, reunidas sob a Diretoria de Ensino Agrícola, foram construídas a partir do decreto 12.742, de 3 de junho de 1942, sendo concluídas entre 1944 e 1945.

Os projetos, segundo publicações na Revista Acrópole, foram desenvolvidos pelo Departamento de Engenharia Rural ou pelo Departamento de Engenharia da Secretaria de Viação e Obras Públicas. As construções foram realizadas por diferentes empresas: em Guaratinguetá, pelo Escritório Técnico de Engenharia Oscar Americano Ltda ${ }^{155}$; em Ribeirão Preto pela Sociedade Construtora de Imóveis e Planejamento Ltda ${ }^{156}$; em Bauru, pela Lindenberg e Assumpção Engenheiros Civis e Construtores 157. A Escola Prática de Agricultura Fernando Costa teve estudos realizados pouco tempo após o decreto de criação das Escolas ${ }^{158}$, como visto em alguns carimbos de projetos (ainda que não sejam do projeto que foi efetivamente

\footnotetext{
${ }^{153}$ Ainda que tal registro não seja responsabilidade destes órgãos, encaminhamos e-mails para os setores de arquivo e bibliotecas, que encaminharam respostas negativas à existência de tal acervo.

154 MARTINS (1991), pg. 222.

${ }^{155}$ ACRÓPOLE (1944), julho, pgs. 90 e 91 Escolas práticas de agricultura e ACRÓPOLE (1945), maio, pg. 1. Escola Prática de Agricultura Dr. Paulo de Lima Côrrea.

${ }^{156}$ ACRÓPOLE (1944), jan, pg.288-289, Escola Prática de Agricultura Getúlio Vargas; nesse caso, o projeto é do Departamento de Engenharia da Secretaria de Viação e Obras Públicas, assinado por Hernani do Val Penteado, que também é autor da Escola Preparatória de Cadetes em Campinas e mais tarde, em 1949, do Terminal do Aeroporto de Congonhas, em São Paulo. Em menos de dez anos o local foi doado para a USP e transformado no que é hoje o Campus Ribeirão Preto. O prédio central atualmente é a sede da Faculdade de Medicina de Ribeirão Preto (FMRP-USP). Trata-se de um complexo tombado em nível estadual pelo Conselho de Defesa Estadual de Patrimônio Histórico, Artístico, Arqueológico e Turístico (CONDEPHAAT), em 1994 (Resolução SC/7).

157 ACRÓPOLE (1946), ago, pg. 109-111, Escola Prática de Agricultura Gustavo Capanema. Nesse caso, o projeto também é do Departamento de Engenharia da SVOP.

${ }^{158}$ Decreto-Lei 12742, de 03.06.1942: Dispõe sobre a criação de Escolas Práticas de Agricultura. Fonte: Assembleia Legislativa do Estado de São Paulo.
} 
executado). Há indícios, inclusive, que as desapropriações foram iniciadas antes do Decreto, o que denota o interesse político do Interventor do Estado.

As obras em Pirassununga foram realizadas pela Sociedade Construtora Brasileira S/A, que em grande esforço de engenharia as concluiu em menos de dois anos. Pela técnica construtiva adotada (edifícios em concreto armado e alvenarias de vedação) e pelo porte dos edifícios (o maior possui $9.000 \mathrm{~m}^{2}$, outros quatro edifícios possuem entre 1.000 e $2.000 \mathrm{~m}^{2}$ ), e por existirem mais de 60 frentes de obra simultâneas, podemos inferir que haviam várias equipes de engenharia e de detalhamento de projetos (figura 43). No seu período, tratava-se de uma das maiores obras públicas do Brasil ${ }^{159}$.

Figura 43: Recorte da publicação que menciona a obra da Escola Prática de Agricultura em Pirassununga.

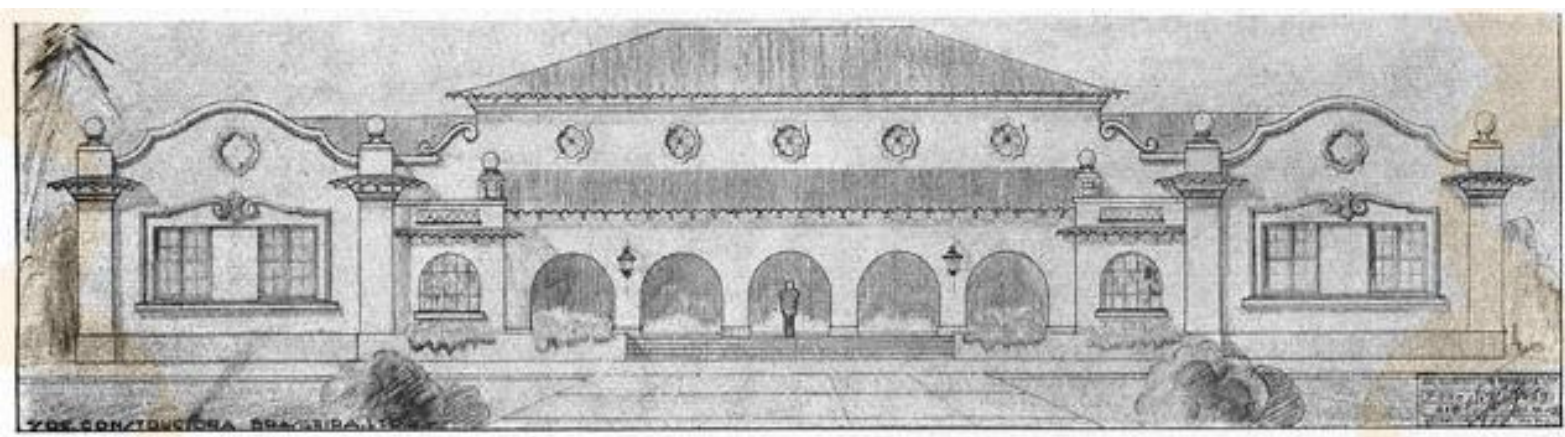

Associação_"Rgro-Pecuaria'do Vale do'Mogy-Guassú em Pirassununga - Clube de Campo - Fachada principal!

Fonte: ACRÓPOLE (1944), maio, pg. 6.

A empresa construtora dedicava grandes esforços, interesse e atenção a este contrato. Entre seus sócios figurava o senador Roberto Simonsen, político com afinidades com o Interventor Fernando Costa. Conhecidos do meio político, foram deputados no mesmo período, pelo Partido Republicano Paulista (PRP) e no final do governo varguista ingressaram juntos no Partido Social Democrático (PSD), pelo qual Costa sairia candidato a governador (falecendo antes da eleição) e Simonsen se elegeria senador (falecendo um ano depois de assumir o cargo). Simonsen, em seus discursos sobre agricultura, citava Fernando Costa, como exemplo de conhecedor dos problemas da área ${ }^{160}$.

\footnotetext{
159 Em ACRÓPOLE (1944), maio, pg. 6, Realizações etc., lê-se que havia 60 unidades de construção na obra da Escola Prática de Agricultura em Pirassununga. Ver também ACRÓPOLE (1944), dez, pg. 245 e ACRÓPOLE (1945) julho, pg.64.

160 SIMONSEN (1944), pg.7.
} 
O projeto de modernização do país defendido por Fernando Costa passava por um processo de modernização da atividade agropecuária. Em todos os cargos públicos que ocupou, Fernando Costa se valia do conhecimento técnico de engenheiro agrônomo para defender seu ideal e trabalhava com afinco para construir a infraestrutura necessária ${ }^{161}$. Sua lista de realizações é muito vasta: em Pirassununga praticamente todas as instituições públicas presentes são resultado de sua ação; os Institutos Nacionais de Agricultura, hoje transformados em Universidades Rurais; a Escola Nacional de Agricultura, atual UFRRJ; o Parque da Água Branca e o Parque da Água Funda, em São Paulo; o Instituto Biológico, também em São Paulo; inaugurou postos zootécnicos e estações experimentais pelo país; idealizou a campanha do gasogênio; incentivou e promoveu a descoberta de petróleo no Brasil (na Bahia); entre várias outras ações de caráter local, principalmente ligadas à agricultura ${ }^{162}$.

De acordo com Campos (2012), a maioria dessas decisões políticas envolviam a construção de edifícios ou estabelecimentos que abrigassem as novas instituições. A proximidade entre o campo político e a inciativa privada, em especial as empreiteiras de construção civil, era muito oportuna. As empreiteiras realizavam "lobby" junto às esferas governamentais e estas, interessadas na realização das obras de modernização do país, ofereciam grandes possibilidades para o crescimento das empreiteiras. A partir de um projeto político, de uma crença inquebrantável que tal ação (que envolvia determinada obra) promoveria o desenvolvimento do país, Estado e empreiteiras desenvolviam o projeto de construção. O poder das empreiteiras no Estado de São Paulo precede o enorme poder que constituiriam ao longo dos anos, com o auge nos governos militares pós-1964. Essa política tem início no governo estadual de Washington Luís, entre 1920 e 1924, com a célebre frase que dizia: "governar é construir estradas". Os políticos do PRP, incluindo Fernando Costa, se imbuem da mesma lógica ${ }^{163}$.

\footnotetext{
161 Conforme média metragem documentário "O Idealista Realizador" (1994) (Prefeitura do Município de Pirassununga). Acessado em 30/10/2016. https://pirassunungareceptivo.com.br/fernando-costa-oidealista-realizador/

$162 \mathrm{Na}$ bibliografia de Fernando Costa há listas de realizações em publicações que resumem o seu tempo ocupando cada cargo público. DEIP (1943). Fernando Costa e sua vida pública.

163 CAMPOS (2012), pgs. 45-59.
} 
Diretamente ligado a esse projeto de modernização, estava o projeto de educação no campo. As escolas de agricultura em diversos níveis de formação eram essenciais para a consecução desse objetivo. E a Escola Prática de Agricultura em Pirassununga, sua cidade, provavelmente foi acompanhada muito de perto por seu idealizador.

\subsubsection{As condições ambientais}

A Escola Prática de Agricultura ocupava originalmente uma área de mais de 2.300 ha ao norte e noroeste da cidade de Pirassununga ${ }^{164}$. Centralizada ao redor de uma antiga propriedade, de posse de um proprietário denominado "Major Rolla" (que é nome de rua no município), várias outras pequenas propriedades foram desapropriadas para recompor a gleba (figura 41). Segundo entrevistas, essas propriedades eram tipicamente de subsistência, porém, graças ao solo adequado a produções comerciais, possuíam rentabilidade que garantia às famílias condições de vida suficientemente adequada. O processo de recomposição da gleba foi traumático, com algumas famílias permanecendo no terreno - porém trabalhando como funcionários na nova instituição de ensino - enquanto outras foram para outros locais. Há uma lenda reproduzida na cidade - e não foi possível confirmarmos com documentação - que houve suicídios entre aqueles que não queriam deixar suas terras ${ }^{165}$.

Quanto às características climáticas, o município de Pirassununga está em área de transição do clima Subtropical Úmido, com invernos secos e temperatura média inferior a $18^{\circ}$ no mês mais frio e média anual superior a $22^{\circ}$ (Cwa), para Tropical com Estação Seca (neste caso o inverno), com temperaturas altas (acima de $22^{\circ}$ durante o ano) ${ }^{166}$.

\footnotetext{
164 Hoje ocupa 2.240 hectares, conforme certificação cadastral rural no Instituto Nacional de Colonização e Reforma Agrária (INCRA). As perdas de área referem-se às doações para a construção e duplicação da SP-330, conhecida como Rodovia Anhanguera.

${ }^{165}$ As informações deste parágrafo são repetidas em conversas com descendentes de funcionários da antiga Escola Prática de Agricultura, que continuam trabalhando e vivendo no mesmo lugar. Há famílias que estão na terceira ou quarta geração, como os Rosim, os Pavão, os Tuckmantel, entre outras. TELES e IOKOI (2005) também apresentam depoimentos com esse conteúdo.
}

166 CEPAGRI (S/D). 


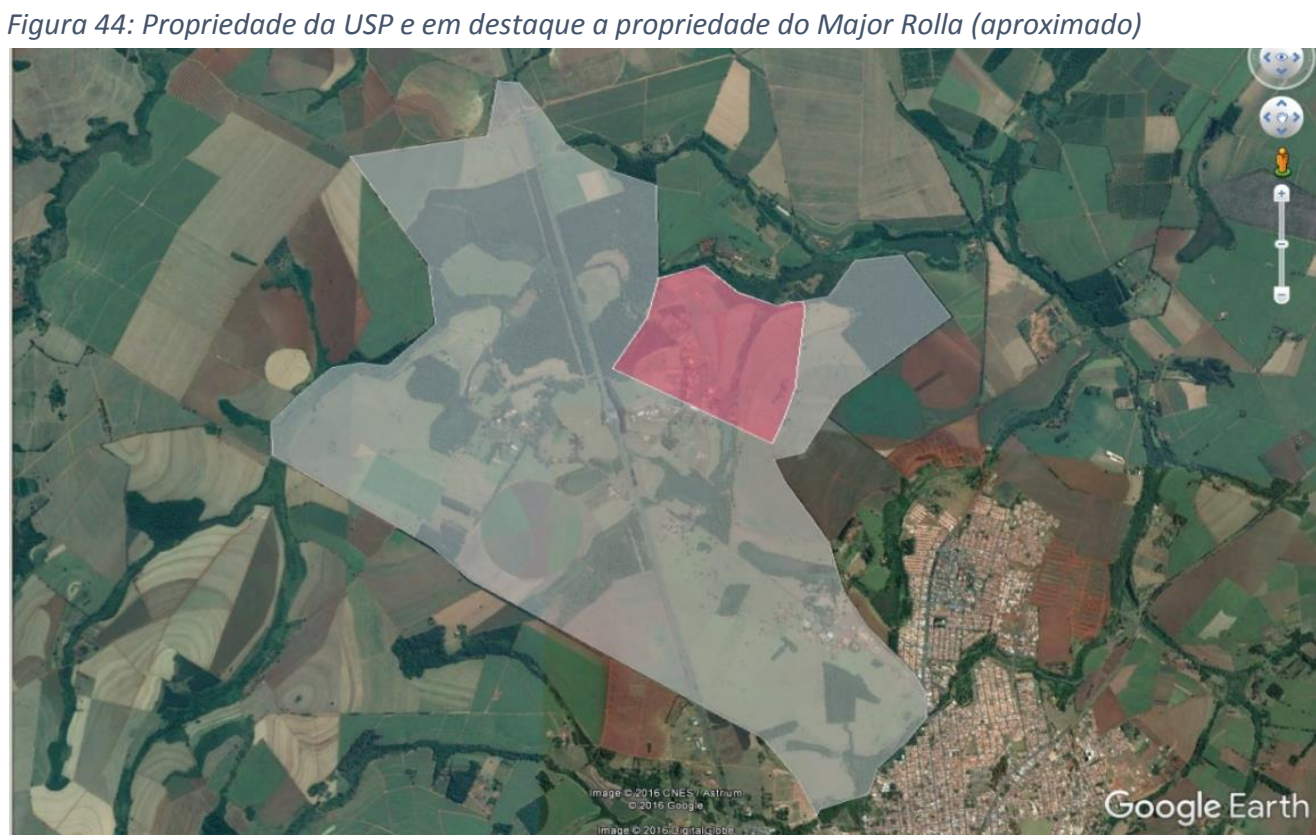

Fonte: autoria própria sobre base do Google Earth.

Com relação aos aspectos pedológicos, a gleba possui terras em latossolo vermelho eutroférrico ${ }^{167}$, que possuem reconhecida alta fertilidade e altos teores de ferro. Os latossolos vermelhos da localidade são argilosos, portanto compactáveis e - com o passar do tempo - pouco úmidos. Essas condições são muito adequadas para a agricultura, porém também podem se prestar à pecuária.

O uso do solo desde décadas antes da formação da Escola Prática de Agricultura era dedicado à agricultura, portanto bastante antropizado. No entanto, até hoje resistem algumas manchas de Floresta Estacional Semidecidual ${ }^{168}$.

Durante a construção da Escola Prática de Agricultura alguns cursos d'água pré-existentes foram represados, dando origem a oito açudes ou lagos artificiais. Depois, ao longo do tempo, um deles secou e outro foi construído. Nenhum dos cursos d'água tem volume d'água significativo, nem há quantidade relevante de nascentes (as poucas nascentes existentes estão bem preservadas).

Do ponto de vista geomorfológico, a área se encontra na classificação D112 (Depressão do Rio Mogi Guaçu), composta por colinas com topos amplos, com altitudes entre 500 m e 700 m, inserida no que se convenciona denominar "Depressão Periférica Paulista" ${ }^{169}$.

\footnotetext{
167 IBGE (2001).

168 MMA (2006).

169 ROSS (1996).
} 
Todas essas condições geográficas permitem avaliarmos que a escolha do local para implantação da Escola Prática de Agricultura reuniu o interesse político, certamente por imposição do Interventor e ex-prefeito Fernando Costa, com os interesses técnicos, já que a área é tecnicamente adequada - e até bastante indicada - para as atividades agropecuárias, permitindo produção intensiva. As dimensões superlativas da gleba que abrigaria a Escola também possibilitariam vários arranjos produtivos, como rotação de culturas e produções, bem como altos índices de produtividade.

\subsubsection{As condições e decisões projetuais}

O processo de composição da gleba da Escola Prática de Agricultura pode ter influenciado de maneira decisiva o projeto inicial. No único desenho que trata da implantação da Escola (figura 45), denominado "Projeto do Parque da Escola Prática de Agricultura Fernando Costa", não há a representação dos limites da propriedade. O enquadramento do desenho mostra o terço final do eixo principal de acesso, o prédio central e seu entorno, o ginásio e entorno e parte da região técnico-produtiva. Não constam os dois primeiros terços do eixo principal, nem as atuais áreas de pastagens e plantações ao redor do núcleo do prédio central ou atrás da região técnico-produtiva. Também não constam as matas ao norte da gleba e as terras cultiváveis além dessas matas.

Sobre o projeto realizado, a primeira observação possível é sobre a densidade de uso do solo. As edificações se situam de maneira esparramada no terreno, com alguns eixos curvilíneos de acesso, que ora entrecruzam o eixo principal, ora distanciam-se. O prédio central, no ponto focal do eixo principal, é a construção de maiores dimensões (mais de $9.000 \mathrm{~m}^{2}$ ). A segunda maior construção, o ginásio de esportes, está conectado visualmente à primeira, porém o percurso para atingi-lo é curvilíneo, duplicando a distância a caminhar. Algumas massas arbóreas enquadram o ginásio. Como se observam em imagens do período de construção do campus, essas massas arbóreas não existiam originalmente. Foram efetivamente plantadas e até hoje há resquícios dessas massas - no entanto veremos mais adiante que o projeto paisagístico foi radicalmente descaracterizado. 


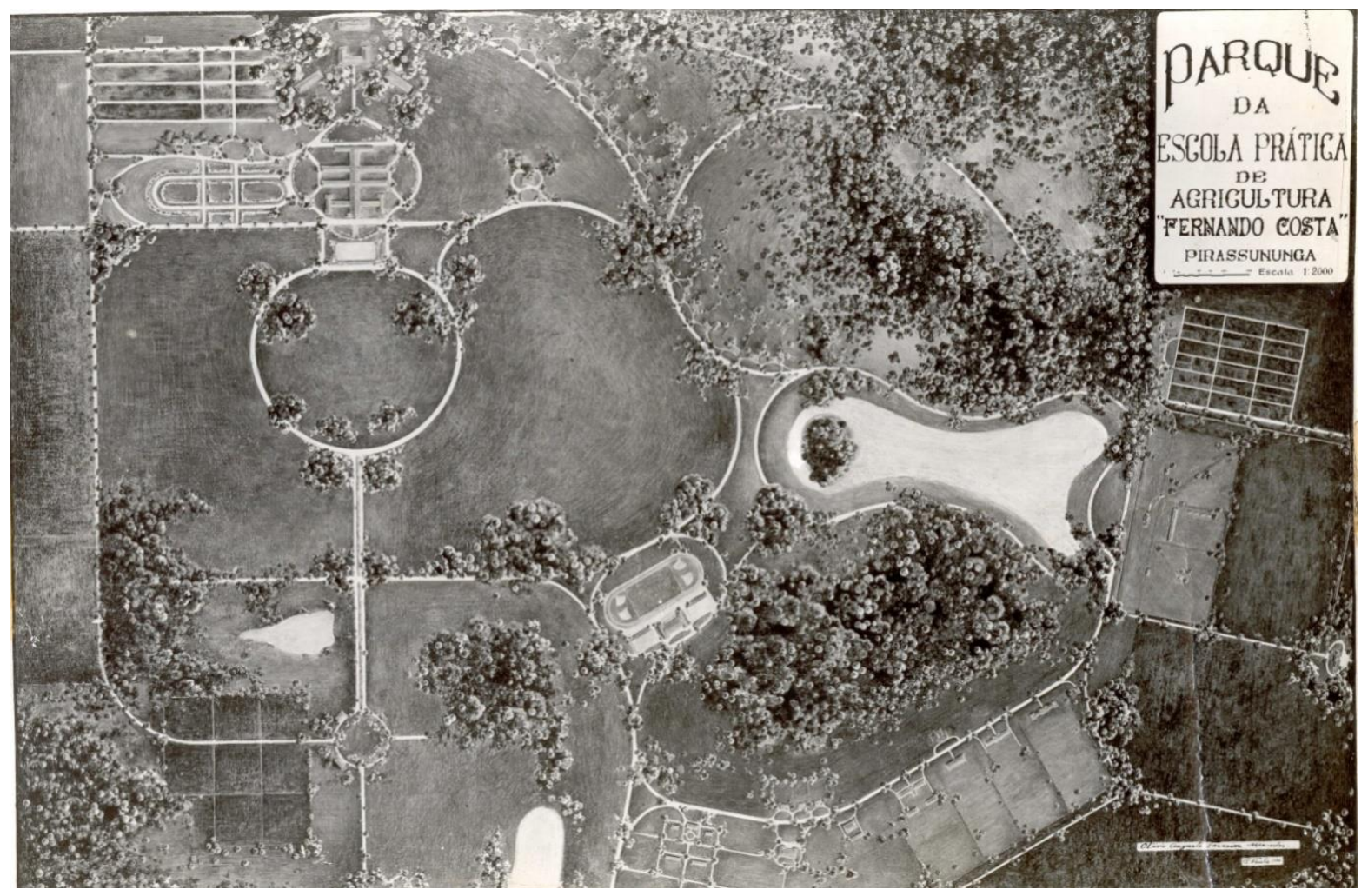

Fonte: Acervo da Prefeitura do Campus Fernando Costa

As demais construções são alinhadas com os percursos curvilíneos, algumas vezes de maneira espelhada (como os prédios de apoio na fachada posterior do prédio central), algumas vezes distribuídos de maneira equidistante (como na região técnicoprodutiva e na colônia dos mestres). As colônias residenciais são compostas por casas de tamanhos diversos, dimensionadas de acordo com o cargo que cada morador ocupava. Ficam soltas no terreno, sem qualquer delimitação de "lote". Ao seu redor, massas arbóreas sem vegetação arbustiva, caracterizando uma implantação parqueada. Há percursos de pedestres apartados da via de acesso.

Os prédios se dispõem no terreno em meio a áreas parqueadas, praticamente todos com jardins frontais (figura 46). As distâncias entre os prédios mais importantes são superáveis a pé - com possibilidades de percorrer áreas sombreadas - o que induz à fruição da paisagem e ao ato de caminhar. No entanto, nas áreas residenciais as casas se dispõem em filas, mas permanecendo o jardim frontal. 
Essa densidade de

Figura 46: Os prédios se dispõem de maneira parqueada, sem cercamentos.

usos e essa ocupação rarefeita obviamente não são características típicas de zonas urbanas. No entanto, também não são características de zonas tipicamente rurais. As áreas produtivas extensivas estão fora da área delimitada pelo desenho do "Parque". As áreas internas

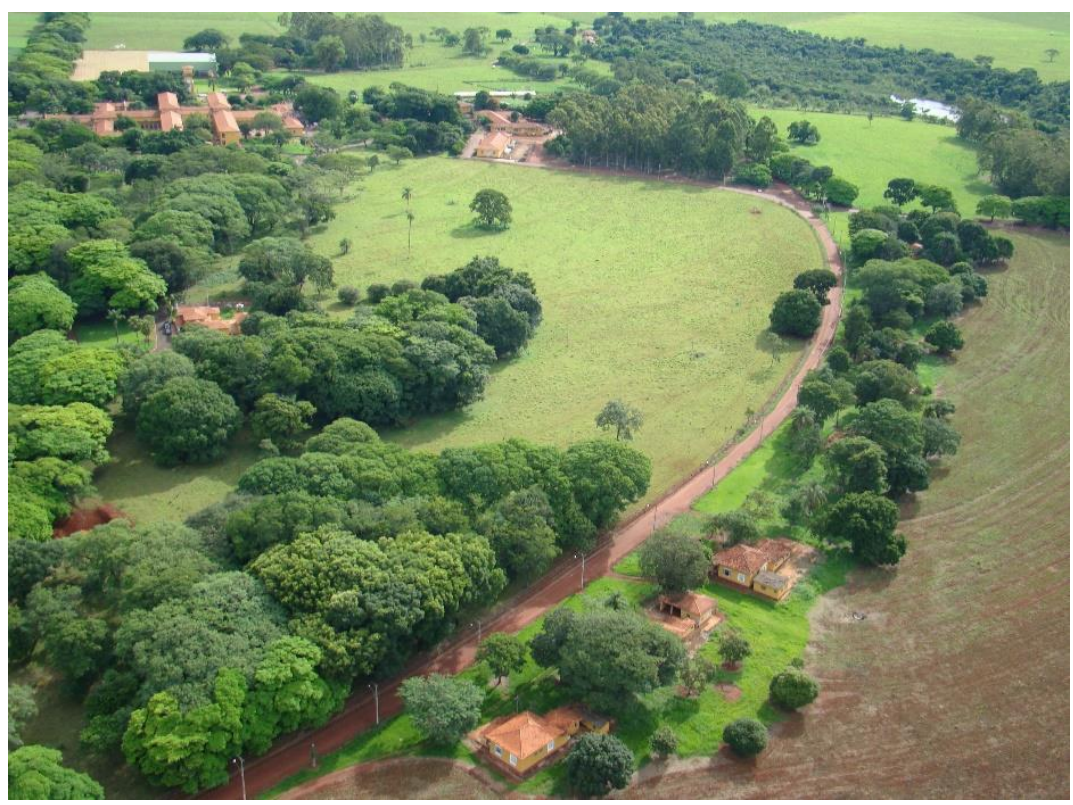
desenho do "Parque" aparentemente possuem usos técnicos, pequenas criações, mas todas experimentais - o que pode ser inferido pelas suas dimensões -, diretamente vinculadas aos usos educacionais.

Essas características inserem o projeto desse "Parque" e da Escola Prática de Agricultura - atual campus, na temática dos territórios universitários.

Fernando de Souza Costa, como agrônomo formado em Piracicaba, teve uma vivência importante, bastante significativa, em sua vida profissional e política, na Escola daquela cidade. E levou essa vivência para o projeto das Escolas Práticas de Agricultura. Em seus discursos o componente técnico e o componente político se entrecruzam com frequência. Ao descrever as riquezas do país, não se contém e assim afirma: "em tão rico e grandioso cenário, a ação do homem técnico não pode deixar de se fazer sentir", depois explicando como esse homem técnico deve trabalhar para promover o engrandecimento nacional ${ }^{170}$.

Outro elemento importante do projeto é o eixo principal, retilíneo, culmina em uma enorme rotatória, conforme a cota do terreno se eleva. O ponto escolhido para a construção do prédio central é relativamente mais alto, no limite de uma crista (figura 47). O ponto em que o prédio se situa o coloca em grande evidência, sendo observável

170 COSTA (1941), pg. 6. Outro exemplo é o "Hino à Terra", discurso pronunciado pelo Interventor Fernando Costa em Espírito Santo do Pinhal, em 12 de junho de 1943, publicado como livro no mesmo ano. (COSTA, 1943). 
à distância e criando uma praça em sua fachada principal que também possui vistas privilegiadas. Além disso, permite que o sistema de esgotamento flua com facilidade até o ponto de deposição, na cota mais baixa do território, a menos de dois quilômetros de distância.

O eixo é um leve aclive, que na rotatória se acentua. Conforme se dobra a rotatória, diferentes visuais da paisagem se abrem, convidando o visitante (e mesmo os que cotidianamente ali circulam) a fruir da amplitude da vista (figura 48). Ao redor, contornando essa área ocupada pelos eixos de circulação e construções, há áreas produtivas e, mais além, acompanhando os fundos de vales, matas preservadas. Hoje essas matas compõem uma unidade, interligando-se, como preconiza a legislação ambiental e como é desejável para a melhor manutenção das

\section{Áreas de Preservação} Permanentes (APP). Porém essas matas eram muito mais modestas no período de constituição da Escola Prática de Agricultura, conforme algumas fotografias da época permitem observarmos (figura 49). O sistema viário, disposto Figura 47: A rotatória no cume do eixo principal e o prédio central. Figura 48: As vias curvilíneas que desdobram visuais.

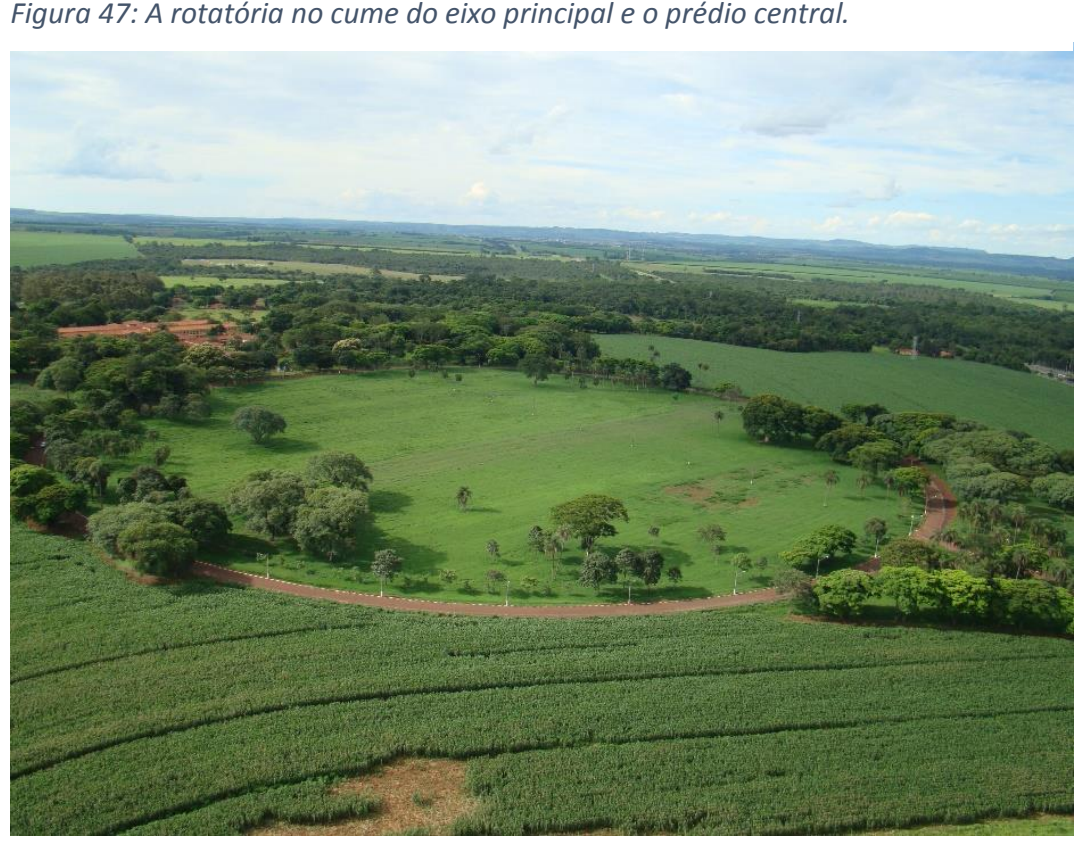

Fonte: foto do prof. César Gonçalves de Lima.

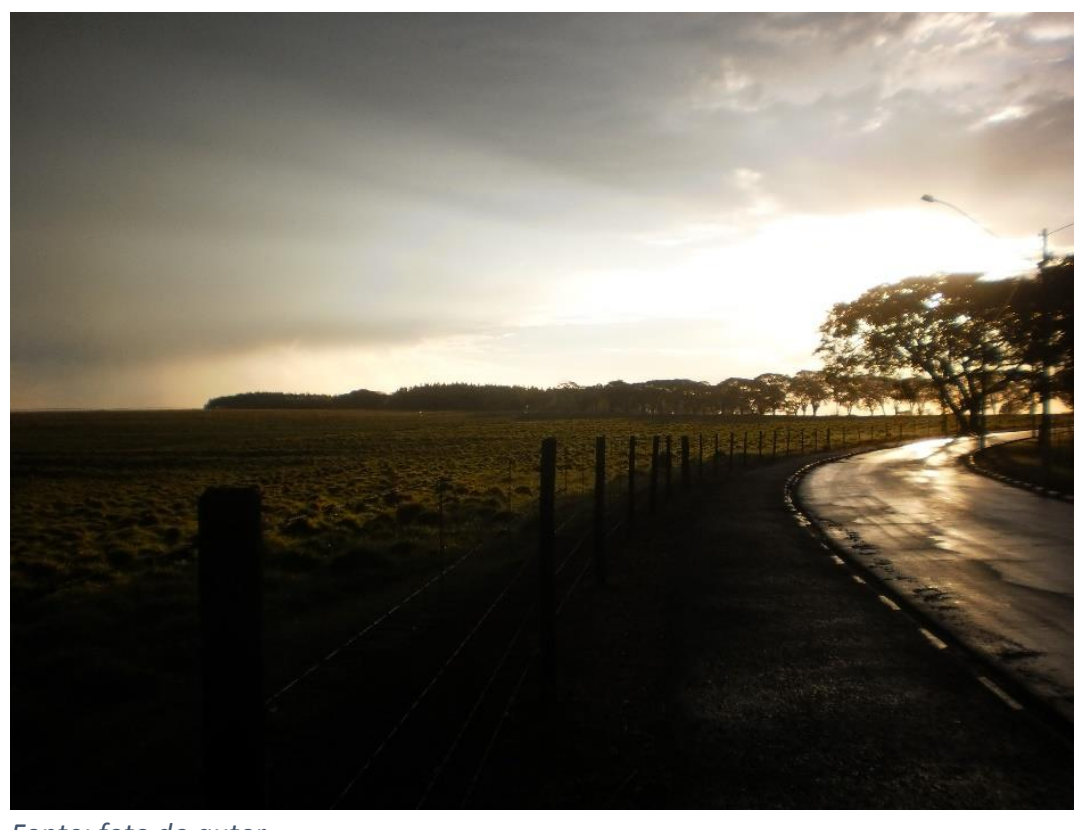


diagonalmente às curvas de nível, permite que o sistema de drenagem seja resolvido superficialmente.

exceção é o eixo principal, que algumas vezes se aproxima de corpos d'água, e eleva a cota de implantação final.

\section{Essas}

características híbridas
Figura 49: Fotografia de meados dos anos 50, com vegetação ainda modesta.

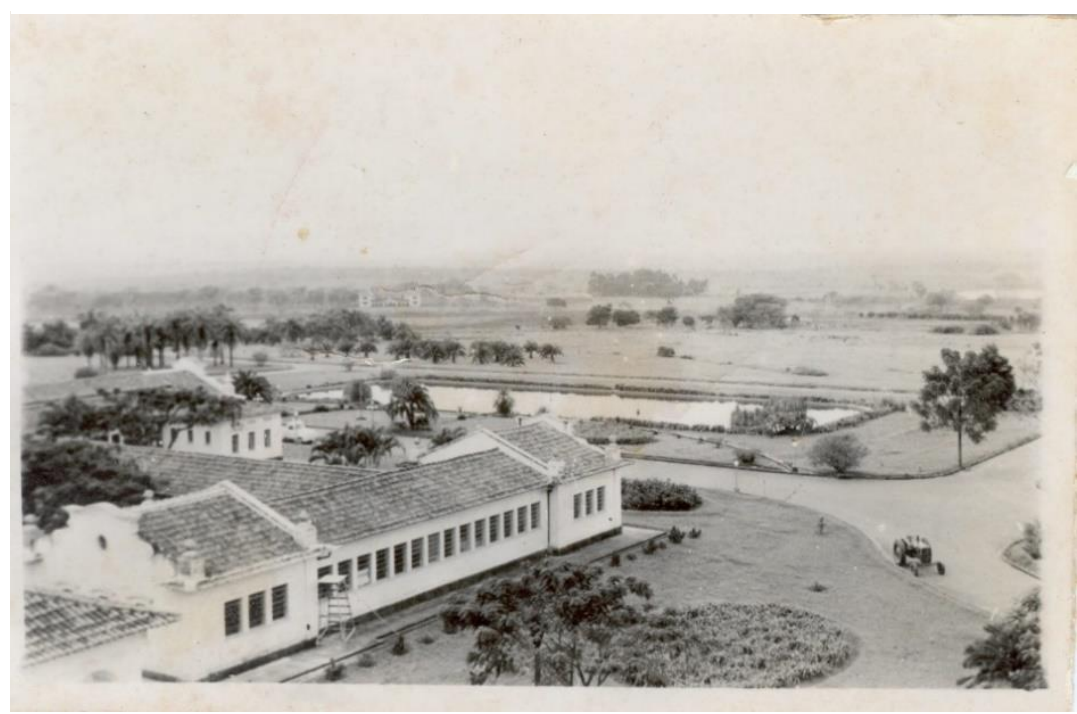

Fonte: Acervo FZEA.

da paisagem, ora mais identificadas com o ambiente rural, ora menos próxima dessa realidade, nos exigem certa precaução para repetir análises típicas de áreas urbanas, que nos induziriam a inserir esse projeto em um determinado estilo ${ }^{171}$. Guardadas essas precauções, identificam-se características de pelo menos dois estilos no projeto: a cidade jardim e o city beautiful. $\mathrm{O}$ hibridismo da paisagem e as características da implantação também aproximam o projeto das propostas de Frederick Law Olmsted, conforme vimos no capítulo anterior.

Nos apoiamos em Gravagnuolo (1998) para identificar nessas características, que destaca a estética do pitoresco e a consequente adoção de estratégias de valorização da paisagem - obviamente dentro do contexto inglês, no qual as primeiras realizações da cidade jardim se inserem ${ }^{172}$. Em suas palavras:

"Surpreende, efetivamente, a extraordinária capacidade para adequar o traçado do assentamento com a natureza do lugar, seguindo os declives, calculando as perspectivas panorâmicas, exaltando, em suma, as vocações formais do topos" 173 .

\footnotetext{
171 O termo "estilo" pode ser entendido pela definição de Walter Gropius: "forma de expressão repetida por um certo período, cujo fundamento, culturalmente saturado, permite a criação de um denominador comum". GROPIUS (1997), pg. 132.

172 GRAVAGNUOLO (1998). Texto original de 1991.

173 Idem, pg. 121. Especificamente, Gravagnuolo refere-se ao projeto de Hampstead. Foi tomada a liberdade de generalizar, pois esse trabalho apresenta apenas topicamente tais aspectos da cidadejardim, para depois verificar sua existência nos espaços-alvo da pesquisa (campi universitários).
} 
No projeto da Escola Prática de Agricultura essa adequação ao topos foi cuidadosamente tomada. $\mathrm{O}$ traçado do assentamento se adequa com a natureza do lugar, segue os declives, ressalta as perspectivas panorâmicas. Outra sugestão de influência é o vínculo entre o desenho da paisagem e a arquitetura homogênea dos projetos. Já outras características formais importantes para Gravagnuolo, como a disposição dos edifícios em cottages, não aparecem no projeto.

Do city beautiful a característica formal que mais se destaca é a presença de uma via parque que culmina visualmente no prédio principal, que guarda proporções monumentais (na comparação com as demais construções do projeto), situação que repete vários casos de instituições educacionais norte-americanas.

\subsubsection{As condições pedagógicas}

Com relação às exigências pedagógicas para um projeto de uma Escola Prática de Agricultura, a primeira característica que chama atenção é a diversidade de culturas agropecuárias e funções auxiliares no arranjo territorial. Nos projetos iniciais há edifícios dedicados a várias atividades. Agruparemos em funções afins:

a) Galpão de máquinas agrícolas; fábrica de laticínios, de rações; galpão de carroças;

b) Estábulo de touros; estábulo de bezerros; apiário; ceva de suínos; pocilga; cavalariça, ordenhadeira; aviários diversos; reprodução de palmípedes; aprisco;

c) Um pavilhão de veterinária principal e um pavilhão auxiliar;

d) Pavilhão de indústrias agrícolas (com área para álcool, vinhos, amidonaria, conservas, vinagres, desidratação de cereais, sabonetes e óleos);

e) Residências para mestres, professores, funcionários, organizadas em colônias;

f) Cocheira para horticultura;

g) Seção de fiação; oficinas de couros, selaria, carpintaria, mecânica, ferraria; sirgaria; matadouro;

h) Parque de exposições com galpões de exposição de equinos e de bovinos, com arquibancada e circuito; 
i) Um grande almoxarifado;

j) O prédio central, antes conhecido como sede, que incluía a moradia estudantil, áreas didáticas (como salas de aula, alguns laboratórios), refeitório, lavanderia, áreas de convivência, auditório, administração;

k) Um ginásio de esportes;

I) O "Clube de Campo da Associação Agropecuária do Vale do Rio Mogi";

m) Portal de acesso com guarita;

Além dos edifícios, há outras delimitações do uso do solo, facilmente identificáveis:

n) Áreas cercadas anexas aos edifícios para criações de animais;

o) Áreas cercadas para pastagens ou culturas agrícolas.

Foram encontrados projetos não edificados para outros usos, como separador de grãos de café e armazém de expurgo de sementes de algodão.

Outras foram construídas no período de inauguração ou posteriormente, porém ainda no período de funcionamento como Escola Prática de Agricultura, mas não foram encontrados nenhum projeto a respeito: a separadora de arroz, alguns aviários, um curral e algumas instalações técnicas como estações de tratamento de água e de esgotos.

O arranjo desses usos técnicos possui uma lógica própria ao sistema agropecuário (figura 50). As funções essencialmente produtivas, de caráter experimental, estão distribuídas junto ao local que hoje é conhecido como Estrada do Povo. No limite norte há a seção de horticultura, que na imagem é representada como um sistema reticulado. Na sequência, rumo ao eixo principal, há a pocilga, onde até hoje é sediada a Seção de Suinocultura. Depois, com distribuição quase equidistante, se distribuem os usos pecuários e das indústrias de transformação, até os aviários, no limite sul desta estrada. Há outros dois setores técnicos: do lado oposto da Estrada do Povo, próximo à rotatória do eixo principal; e nos fundos da Sede, ao lado do galpão de máquinas agrícolas.

As áreas dedicadas ao paisagismo e parques se concentram nas redondezas da Sede, com destaque para a praça frontal, ainda existente, e do lado esquerdo, onde havia a previsão de um jardim que nunca foi construído. Ali foi implantado o campo de futebol, em algum momento anterior ao fechamento da Escola Prática de 
Agricultura. Nota-se, também, uma espécie de pista de atletismo na parte frontal do Ginásio. Não foi possível identificar se essa pista foi efetivamente construída ou não, nem com imagens, nem com indícios físicos na localidade.

Concluindo, as áreas habitacionais foram dispostas em áreas mais distantes tanto das áreas produtivas, como das áreas didáticas e de uso dos alunos. Esse afastamento poderia resultar em maior sossego e silêncio para os residentes na Escola Prática de Agricultura.

Figura 50: Usos definidos pelo projeto original (leitura possivel).

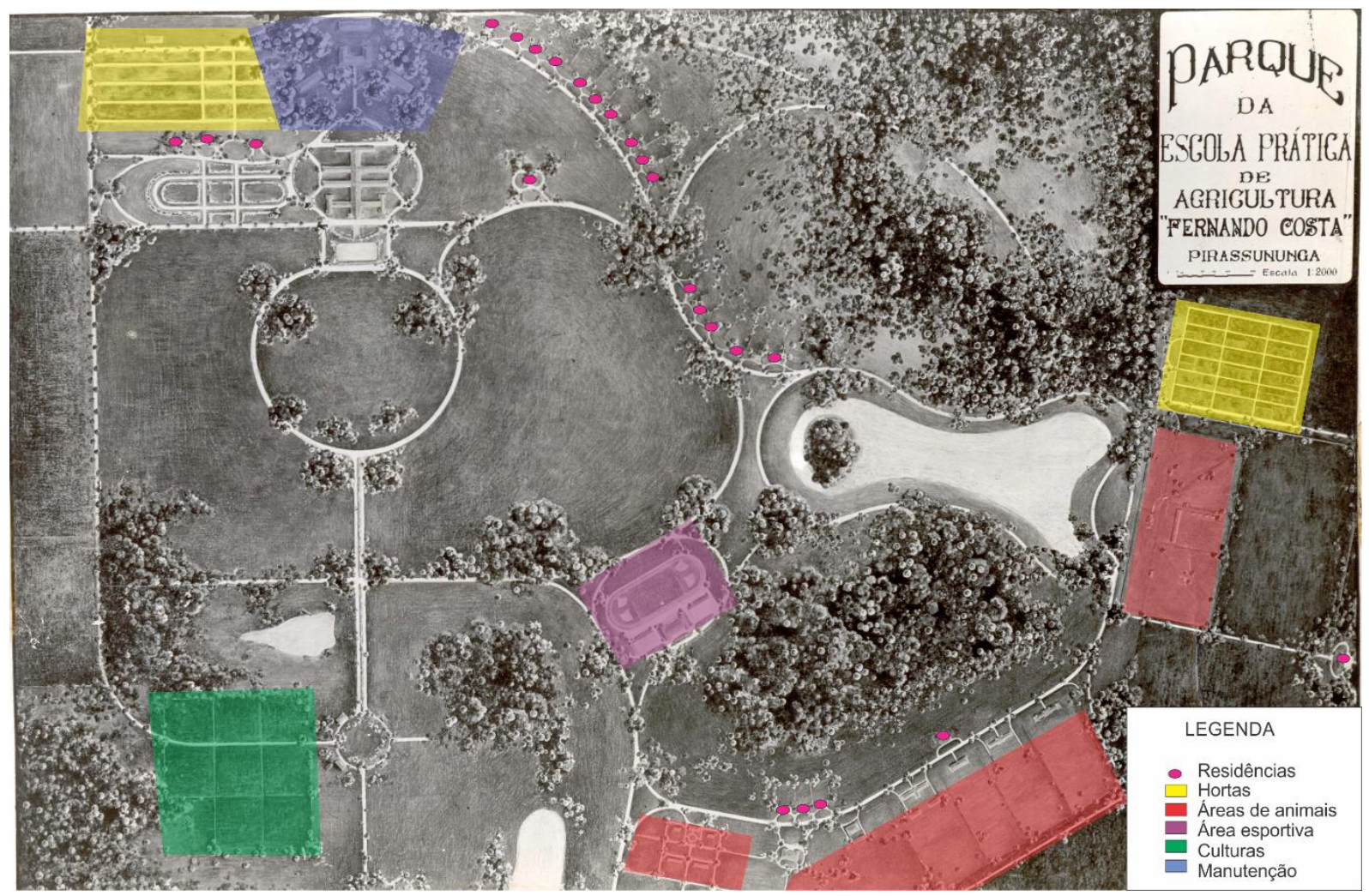

Fonte: imagem modificada pelo autor, a partir de original do Acervo da Prefeitura do Campus.

\subsection{A relação entre Pirassununga e a Escola Agrícola}

O cenário da cidade de Pirassununga antes da gestão prefeitural de Fernando Costa era bastante desolador: fundada em 1865, nos quarenta anos seguintes tornouse um pequeno centro urbano, com vinte e poucos quarteirões, sem pavimentação ou calçamento e com um comércio local que se detinha no básico necessário para o serviço da pequena população urbana e das fazendas ao redor. Em 1878 foi inaugurada a estação do ramal da Companhia Paulista de Estradas de Ferro. Desde 
1896 a cidade contava com uma usina no córrego do Bebedouro, oferecendo energia elétrica, mas não possuía rede de drenagem de águas pluviais e redes apenas iniciais de afastamento de esgotos e indústrias sem importância econômica. A área rural não se destacava e possuía animais comuns. A arrecadação era irrisória ${ }^{174}$.

Quando Fernando Costa torna-se o Prefeito de Pirassununga, em 1913, promove inúmeras melhorias nas feições da cidade e também na infraestrutura urbana e rural, permitindo assim 0 desenvolvimento econômico do

município. Também realiza gestões junto a outros órgãos para sediar instituições públicas na cidade: assim consegue trazer o $2^{\circ}$ Regimento de Cavalaria Divisionária do Exército Brasileiro ( $\left.2^{\circ} \mathrm{RCD}\right)$, atual $13^{\circ}$ Regimento de Cavalaria Mecanizado do Exército Brasileiro (13 RCM), em 1920 e a hidrelétrica na Cachoeira de Emas, construída em 1922 pela Central Elétrica Rio Claro. Também nos anos 20 o antigo "Caminho do Anhanguera" é ampliado no rumo do interior, a partir de Campinas até Ribeirão Preto, passando pelo centro urbano de Pirassununga - no sentido norte foi implantada muito próximo da futura Escola Prática de Agricultura, com o nome de "Estrada para Porto Ferreira" (figura 51).

Ocupando seus cargos públicos, Fernando Costa incentiva a implantação de uma série de projetos rurais experimentais junto a proprietários de terras, o que abre

174 TELES e IOKOI (2005), pg. 47. 
caminho para a futura chegada de outros órgãos públicos: a Escola Prática de Agricultura e a Estação Experimental de Piscicultura, a primeira do país, construída em 1939 quando Fernando Costa já era Ministro da Agricultura. Esta estação é o atual Centro Nacional de Pesquisa e Conservação da Biodiversidade Aquática Continental do Instituto Chico Mendes de Conservação da Biodiversidade (CEPTA/ICMBio) ${ }^{175}$.

A inauguração da Escola Prática de Agricultura é um dos momentos altos da história da cidade. Veremos adiante que o intercâmbio entre os estudantes da instituição e a comunidade pirassununguense - desde esse período seminal até hoje - promoveu o progresso social da cidade (figura 52). A chegada da Escola Prática de Agricultura foi festejada pela imprensa local. O semanário mais importante da cidade, ainda existente, publica em 14 de outubro de 1945 uma matéria sobre a inauguração, na qual destaca o papel de Fernando Costa e seu trabalho incessante pelo desenvolvimento do Estado de São Paulo ${ }^{176}$.

A partir daí a relação entre a jovem escola e a cidade vai se fortalecendo. Mesmo no período da crise dos anos 50, antes da incorporação do território à USP, o principal vetor de urbanização na cidade seguia a orientação da portaria da escola, rumo norte. Nos anos 70 o Estado promove programas habitacionais na antiga Figura 52: A praça central de Pirassununga em 1955, com o IEP ao lado direito.

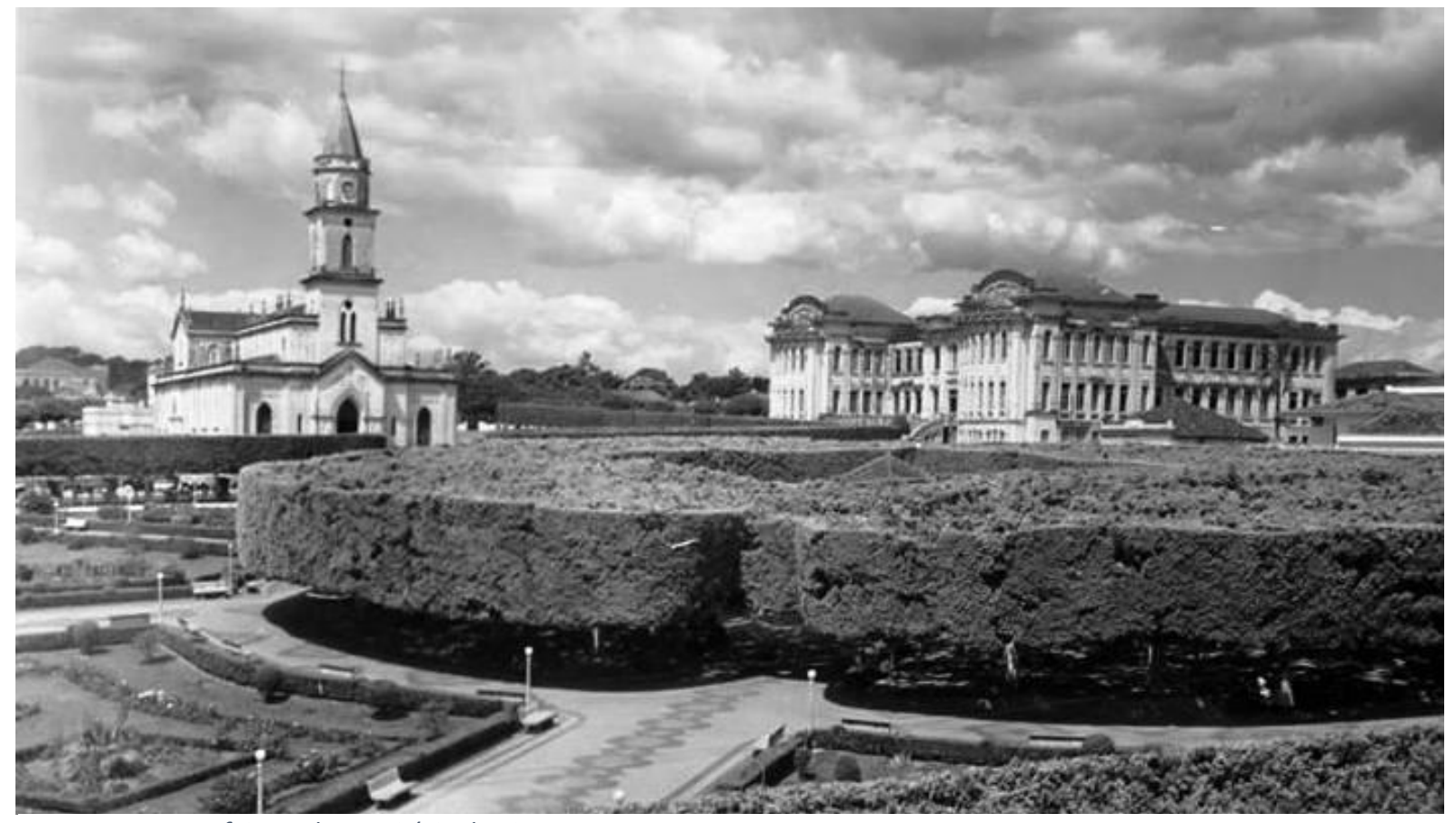

Fonte: Acervo Prefeitura do Município de Pirassununga

175 Id, pg. 55 e COSTA (1941), pg. 102.

$176 \mathrm{lbid}$, pg. 63. 
Estrada de Porto Ferreira, que passa defronte a portaria antiga - além dessa iniciativa oficial outros empreendedores também incorporam loteamentos nesse eixo. Hoje, todos os bairros do entorno abrigam moradias de estudantes, funcionários e serviços para a comunidade universitária. O eixo frontal à portaria é importante para o comércio local e ainda é um vetor de crescimento da cidade (há dois novos loteamentos em obras nesse eixo). A Universidade intensifica a ocupação desse trecho do campus, mais próximo à portaria. Mas essa relação em tempos mais recentes será objeto de análise em posterior momento da pesquisa.

\section{$2.4 \quad$ Estudos comparados}

\subsubsection{Piracicaba}

Figura 53: O projeto Morimont, setorizando o território.

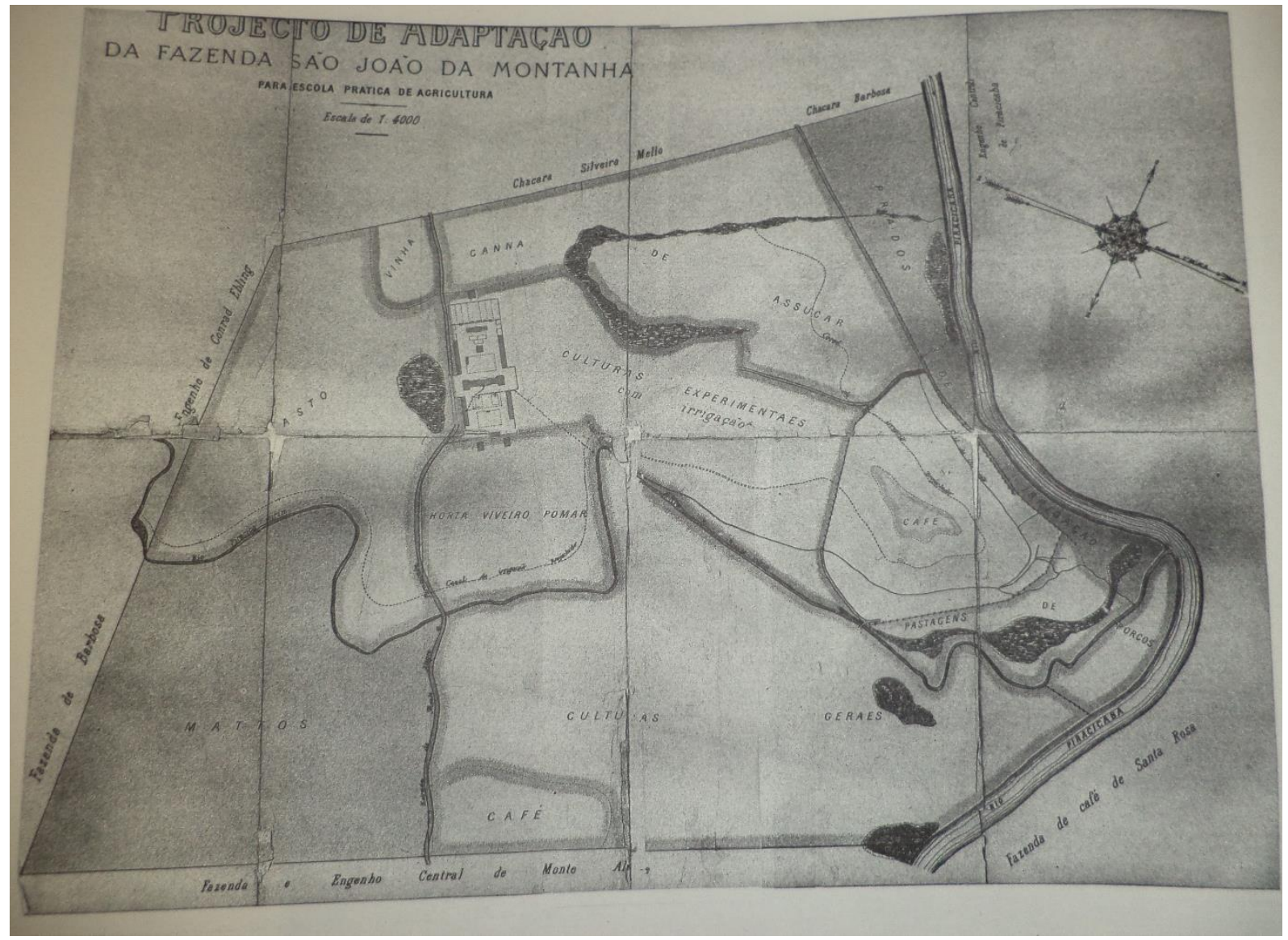

Fonte: PERECIN (2004).

O campus de Piracicaba foi idealizado por Luiz de Souza Queiroz, que era proprietário da fazenda que o abrigava e articulador para a fundação da escola 
agrícola e posterior escola superior. Em 1891 iniciou sua realização, com obras de adaptação na fazenda para transformá-la em um espaço adequado ao ensino. Entre as intervenções planejadas, destacava-se a construção de um prédio principal com quase cem metros de fachada frontal. $O$ projeto foi desenhado por um arquiteto inglês (Alfred Hutchings), que nunca esteve no Brasil e sem mais nenhum outro trabalho publicado ou registrado em publicações de alguma importância ${ }^{177}$. Desse prédio foram construídos apenas os alicerces. O campus, no entanto, só foi sofrer um processo de planejamento em 1894/95, quando um professor belga de agronomia, Léon Morimont, foi contratado para criar um projeto pedagógico e um espaço adequado para esse projeto (figura 53). Esse espaço foi projetado pelo Engo ${ }^{\circ}$ Francisco Henzler, funcionário da Diretoria de Obras Públicas da então presidência do Estado, quando a Secretaria de Agricultura ainda abrigava as Diretorias de Viações e Obras Públicas ${ }^{178}$. Alguns edifícios desse tempo ainda existem: como o antigo prédio de ensino de química e o projeto do prédio principal (inconcluso até 1907). Este último, projeto de um funcionário da Diretoria, José Van Humbeeck. Por alguns problemas práticos e políticos, a escola permaneceu praticamente sem funcionar até 1905, quando finalmente foi reaberta e as obras concluídas. Nesse ano, foi contratado o arquiteto paisagista (também de origem belga) Arséne Puttmans para realizar um projeto de integração do entorno dos prédios

Figura 54: O projeto do parque da ESALQ

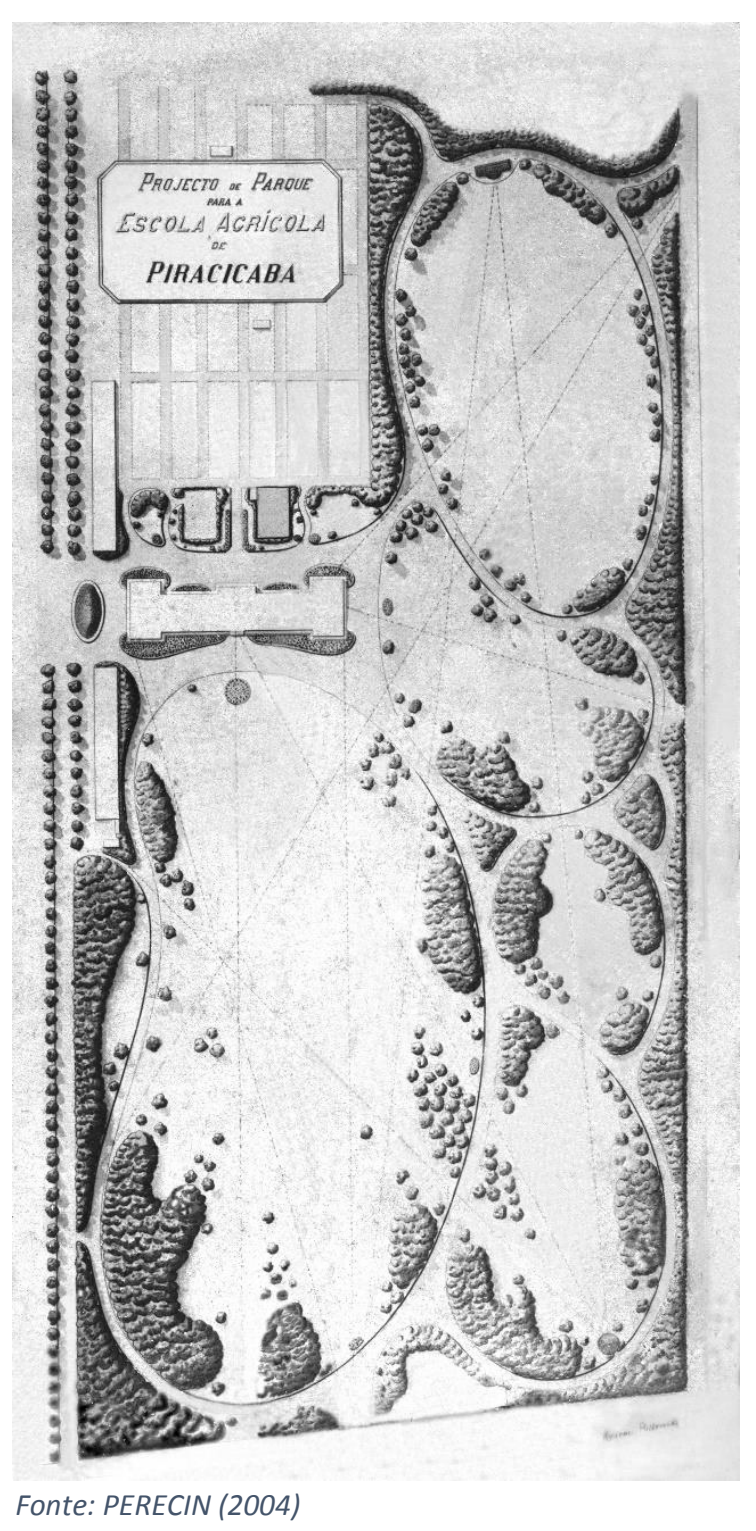

\footnotetext{
177 PERECIN (2004). Pg. 114-115.

178 Idem, pg. 145-147. No entanto, outras fontes informam que o projetista foi o Eng $^{\circ}$ José Van Humbeeck 
mais importantes, que resultou em um parque. Esse parque circundava o prédio principal (finalmente concluído), outras edificações e algumas hortas didáticas (figura 54).

Esse histórico repleto de idas e vindas não chega a descaracterizar a unidade do conjunto, que foi tombado pelo CONDEPHAAT em dezembro de $2006{ }^{179}$. O projeto de Arséne Puttmans (que também foi autor, por exemplo, da Praça da República e do parque do Museu Paulista na cidade de São Paulo), possui características tanto de jardim inglês quanto de jardim francês, com cuidadosa implantação dos maciços arbóreos, dos gramados e das áreas edificadas ${ }^{180}$.

Observa-se, no projeto original (e até hoje), algumas características como a presença das vias curvilíneas destacando visuais e a baixa densidade. A solução original de separar acesso de veículos ao acesso de pedestres pode ser observada, apesar dessa originalidade ter partido de outra necessidade: o trânsito de arados mecanizados (e outros equipamentos agrícolas) fazia parte das inovações pedagógicas dessa escola, e certamente o espaço deveria refletir essa inovação. Dessa maneira, o acesso social poderia ser realizado pelo parque, enquanto que o acesso de máquinas e cargas poderia ser realizado por essas vias circundantes.

Constata-se que o espaço dessa escola foi fortemente determinado pelas práticas didáticas que ali se desenvolveriam. Na figura 55 está representado o parque da ESALQ, em construção. A foto, de 1907, retrata o prédio principal (projeto de 1895 aproveitando-se os alicerces do projeto de 1891), o sistema viário e uma das incipientes massas arbóreas. Esse projeto foi muito pouco alterado ao longo do tempo, com a exceção da demolição do prédio à esquerda do prédio principal (substituído por outro de maiores dimensões) e obviamente do crescimento das espécies arbóreas.

O campus Piracicaba da USP se situa às margens do Rio Piracicaba, em área de 914 ha. Possui atualmente $262.000 \mathrm{~m}^{2}$ de área construída, sendo que a maior parte é bem posterior aos projetos originais. Mesmo o prédio central sofre uma grande

\footnotetext{
179 Ver http://www.esalq.usp.br/noticia/detalhe.php?id=716 e LOURENÇO (2002).

180 Enquanto alguns trabalhos destacam as características de jardim inglês, como BARBIN, outros destacam as características de jardim francês, como PERECIN. Uma observação mais cuidadosa permitirá que assumamos a preponderância das características inglesas, como a paisagem com características de jardim natural, pouca linearidade (apenas a via de acesso à esquerda do edifício principal), visuais privilegiando a massa arbórea e a possibilidade de circular sem a visão de áreas edificadas. BARBIN (1999).
} 


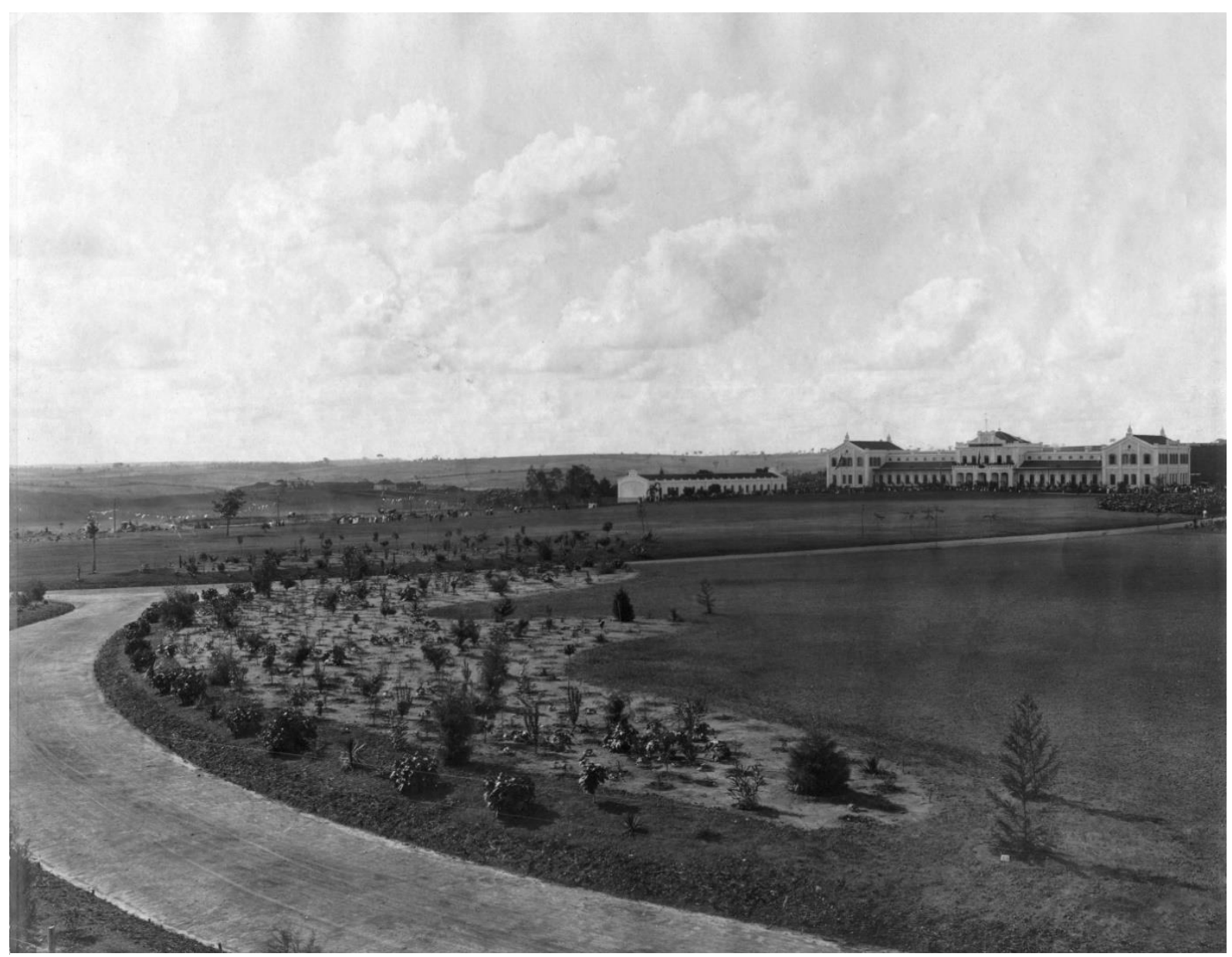

Fonte: PERECIN (2004)

intervenção em 1945, recebendo o segundo pavimento nas conexões com as alas laterais, que originalmente abrigavam apenas corredores de circulação. O parque sofreu poucas transformações, além do óbvio crescimento das espécies vegetais.

Os aspectos físicos do solo indicam boa adequação para a agricultura (solo latossolo vermelho amarelo, a chamada terra roxa), com terrenos igualmente antropizados antes da implantação da escola ${ }^{181}$. Assim como a situação pedológica, a situação geomorfológica é parecida com a de Pirassununga: ambas cidades estão na Depressão Periférica paulista, com terrenos levemente ondulados e vales junto à grandes rios (no caso da ESALQ, no beira-rio) ${ }^{182}$.

A escola foi implantada em uma fazenda que à época se situava fora dos limites da cidade. Piracicaba passou dos 25.000 habitantes em 1890 (na época da fundação

\footnotetext{
181 INSTITUTO AGRONÔMICO (1989).

182 ROSS (1996).
} 
da escola era a quarta cidade mais populosa do Estado) para 76.000 habitantes em 1940 (mais do que a população atual de Pirassununga) até os atuais mais de 390.000 habitantes ${ }^{183}$.

Concluímos que ambos os projetos foram realizados em ambientes que previamente já eram dedicados à agricultura e a pecuária, e que corretamente se adequam para essas finalidades, tanto do ponto de vista ambiental como social. Em ambos os projetos, há um prédio central implantado em meio a um parque, situado em cota levemente mais alta no final de um eixo de acesso. E o arranjo geral do projeto segue determinações pedagógicas - de maneira mais visível em Piracicaba e menos em Pirassununga.

O projeto da ESALQ, com influências de jardins ingleses e uma arquitetura menos neocolonial e mais eclética, foi certamente uma influência para todas as escolas de agricultura instituídas posteriormente no Brasil. Seus aspectos técnicos e projeto pedagógicos influenciaram o arranjo dos mesmos espaços nas escolas posteriormente construídas. A presença de um prédio central, com implantação em local de destaque, entremeado a um parque, acontece nas Escolas Práticas de Agricultura e na antiga Escola Nacional de Agricultura (atual UFRRJ). A exceção é o Instituto de Agricultura em Belém, atual UFRA. Ali há uma praça defronte o prédio central, mas o eixo passa lateralmente ao prédio e o terreno é praticamente plano. 0 prédio fica implantado defronte o rio Guamá, com dimensões amazônicas. O vínculo entre Fernando Costa e sua alma mater não se apaga: sua formação técnica superior em agronomia e seu consequente reconhecimento como um político conhecedor dos assuntos agropecuários é inseparável de seu pensamento realizador ${ }^{184}$.

\subsubsection{Seropédica}

A história da atual UFRRJ se inicia em 20 de outubro de 1910, quando o Presidente Nilo Peçanha assina o decreto que dá origem à Escola Superior de Agricultura e Medicina Veterinária. No início era uma escola sem sede definida,

\footnotetext{
183 IPPLAP (2015).

184 COSTA (1931) pg. 271, discurso "Saudando Piracicaba", proferido em 26 de novembro de 1927, em agradecimento às homenagens recebidas nesta cidade.
} 
circulando entre várias sedes. Primeiramente em um edifício no local onde hoje se encontra o Centro Federal de Educação Tecnológica (CEFET) no bairro do Maracanã, na capital nacional (Rio de Janeiro), depois sendo transferida para a cidade de Pinheiral e em 1917 chegando à Niterói, junto ao Horto Botânico municipal, onde se manteve por oito anos. A seguir, muda-se novamente, para o hoje campus da UFRJ, na Praia Vermelha ${ }^{185}$.

Em 1938, uma sequência de ações conduz à inauguração da UFRRJ. Em agosto é dada a autorização para iniciar as intervenções na antiga "Fazenda Nacional de Santa Cruz", com projetos e obras desenvolvidos pela empresa Mario Whately \& Cia. Em outubro os projetos são aprovados. Em dezembro é decretada a criação do Centro Nacional de Ensino e Pesquisa Agronômica (CNEPA), que incluía a renomeada Escola Nacional de Agricultura e Medicina Veterinária e outro institutos pré-existentes. As obras são iniciadas em outubro, com intensa dedicação na infraestrutura para o funcionamento da escola, levando sistema ferroviário, telefônico, saneamento. É montada uma comissão de acompanhamento composta pelo então diretor da Escola, pelo arquiteto Ângelo Murgel e outros técnicos. Essa comissão foi alterada em 1939, permanecendo o arquiteto Ângelo Murgel e sendo dirigida imediatamente pelo ministro. Ocorrem algumas alterações ao longo dos anos, mas Murgel segue em todas as comissões até maio de 1944. No entanto, a inauguração aconteceria apenas em julho de 1947, depois da morte de Fernando Costa.

O Ministro Fernando Costa já havia tomado contato com o arquiteto Ângelo Murgel na ocasião do projeto do Instituto Nacional de Agronomia de Belém. Em ambos os casos, a arquitetura adotada se alinhava com o neocolonial. Mascaro fala de uma certa relação entre o ambiente rural e a adoção intencional deste estilo para a arquitetura dessas instituições ${ }^{186}$. Um personagem se repete nos casos aqui demonstrados: o então Ministro Fernando Costa tornar-se-á o Interventor Fernando Costa, e em ambos os cargos emplacará o projeto de desenvolvimento e modernização da agricultura tendo como base a educação do homem do campo. $E$, para todos os projetos físicos criados sob sua égide, há algumas semelhanças, como a definição técnica das condições de implantação e a arquitetura com tendências

\footnotetext{
185 Sobre a história do campus Seropédica da UFRRJ nos apoiamos em RUMBELAPAGER (2005), pgs. 91-109.
}

186 MASCARO (2008) pg. 98. 
monumentais em estilo neocolonial.

O edifício principal da Escola Nacional de Agronomia, de características neocoloniais, possui um partido bastante interessante (figura 56). Situa-se no topo de uma pequena elevação, defronte uma grande rotatória na ponta de um eixo bastante largo, retilíneo. Com acesso monumental, abrem-se grandes pórticos no volume com dois pavimentos. Há um claustro central, com jardins ricamente ornamentados, com espelhos d'água e arcadas, remetendo tanto às construções jesuíticas coloniais como às instituições de ensino norte-americanas, que adotaram esse mesmo arranjo pouco mais de um século antes. Algumas soluções, no entanto, são tipicamente nacionais: as grandes arcadas e os ambientes internos possuem grande pé-direito e ventilação cruzada; há frondosa vegetação margeando os eixos de circulação, para oferecer sombras no percurso. Os ambientes didáticos e os prédios auxiliares foram projetados com rigor para acomodar da maneira mais adequada possível os usos bastante específicos para o qual foram destinados.

A implantação é relativamente simples (figura 57). Além da grande rotatória após o eixo central, há algumas vias circundantes aos lagos artificiais na lateral direita do prédio central, que fica em cota relativamente mais alta. A casa do reitor se situa em ponto igualmente privilegiado, entre o lago e o prédio central. Construída com arquitetura em outro estilo - eclético - não nos foi possível identificar o período de sua construção. O restante dos edifícios se situam ao longo de eixos laterais, bem mais discretos e ligados a áreas de produções experimentais. As moradias, organizadas

Figura 56: O edifício principal da UFRRJ.

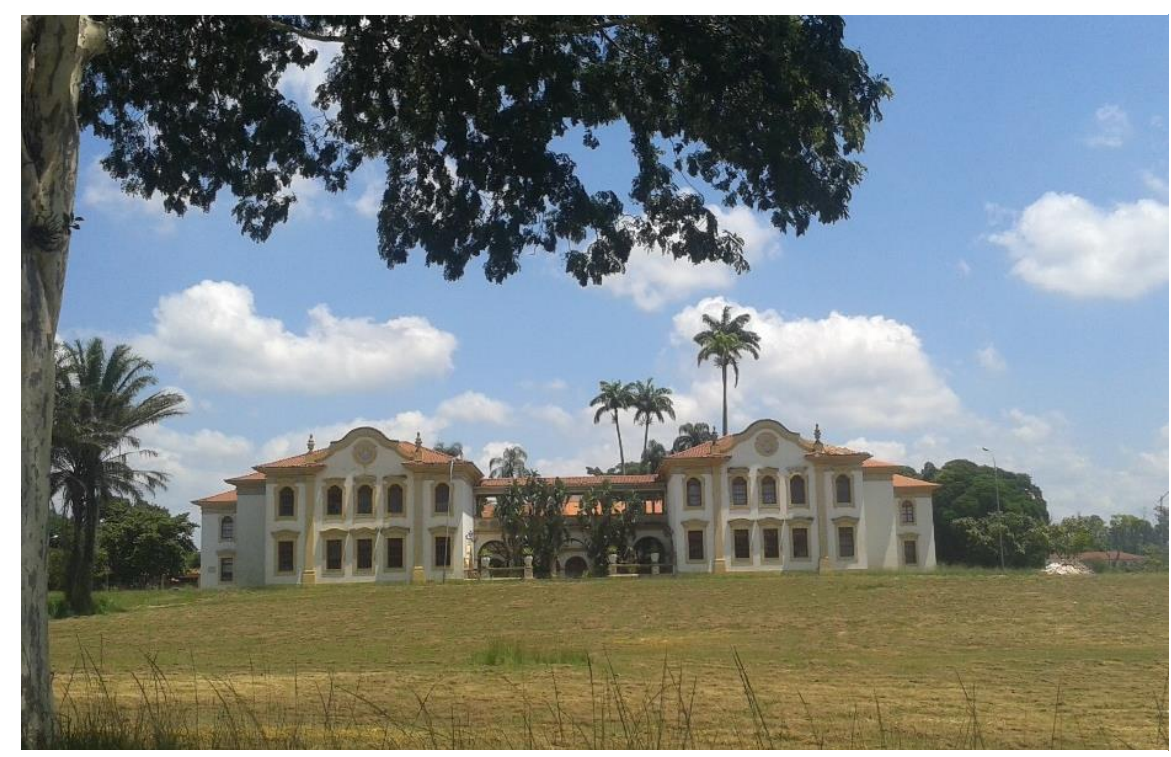

Fonte: Autoria própria. em colônias, ao longo do tempo foram se descaracterizando e sendo delimitadas por muros e gradis, se assemelhando a implantação tão convencional nas cidades brasileiras e indicando um certo "loteamento". 
O solo na localidade de Seropédica (depois emancipado como município em 1995, separando-se de Itaguaí), é do tipo planossolo álico ou podzólico vermelhoamarelo álico. Tais solos não são os mais indicados para a agricultura, exceto em situações bem particulares. O terreno original era ocupado por mangues e matas de baixada, com proliferação de malária, por exemplo ${ }^{187}$. As condições prévias exigiram grandes esforços para a construção, o que justifica os quase dez anos de obra.

As diferenças das condições de adequação ao uso são uma diferença gritante entre os exemplos aqui estudados. Enquanto a Escola Prática de Agricultura em Pirassununga está em local bastante adequado para a produção, Seropédica está em local que se adequa apenas a alguns tipos específicos de produção. Pirassununga era uma pequena cidade, que aos poucos se torna um centro de relativa importância em determinadas cadeias produtivas, e Seropédica se torna uma cidade dormitório, no eixo de influência da zona oeste carioca - ainda que ambas tenham hoje população parecida (Pirassununga pouco mais de 70.000 habitantes e Seropédica pouco mais

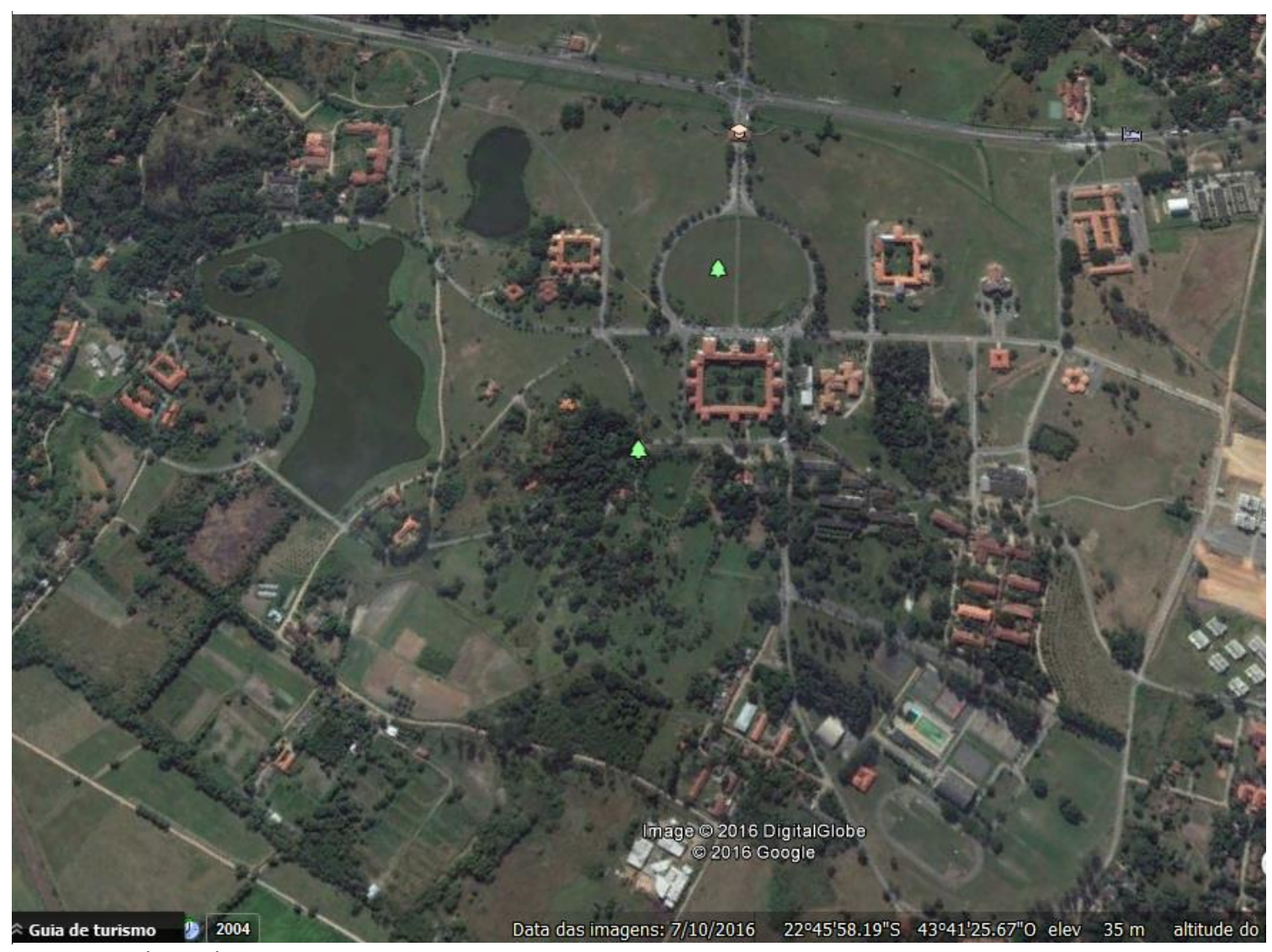

Fonte: Google Earth.

187 RUMBELAPAGER (2005), pg. 90 e MAA (2000). 
de 80.000). O papel das escolas é importante em ambos os casos, mas para Seropédica é mais determinante: até hoje é o maior empregador do município ${ }^{188}$. A cidade cresce ao redor do território da universidade e sua maior identidade é a existência da UFRRJ.

A principal semelhança entre as escolas é a adoção da arquitetura neocolonial, sendo possível observar detalhes arquitetônicos praticamente idênticos em construções dos dois lugares. Apesar do projeto da Escola Nacional de Agricultura ser quase quatro anos mais antigo, as obras foram concomitantes e o idealizador, Fernando Costa, teve papel decisivo na realização de ambas. Não à toa é homenageado com um busto na portaria da universidade em Seropédica (figura 58) e no prédio central da universidade em Pirassununga (figura 38). As comparações não param por aí. A implantação do prédio principal e a própria relação deste com o entorno são similares: grandes volumes que possuem relativa monumentalidade, em ponto de relevo mais alto, com jardins projetados junto ao ponto de acesso ao edifício, após uma enorme rotatória que culmina um eixo central, retilíneo. Esse arranjo se repete em ambos os casos, com a diferença que em Pirassununga esse eixo possui

Figura 58: Estátua de Fernando Costa na portaria da UFRRJ, em Seropédica.

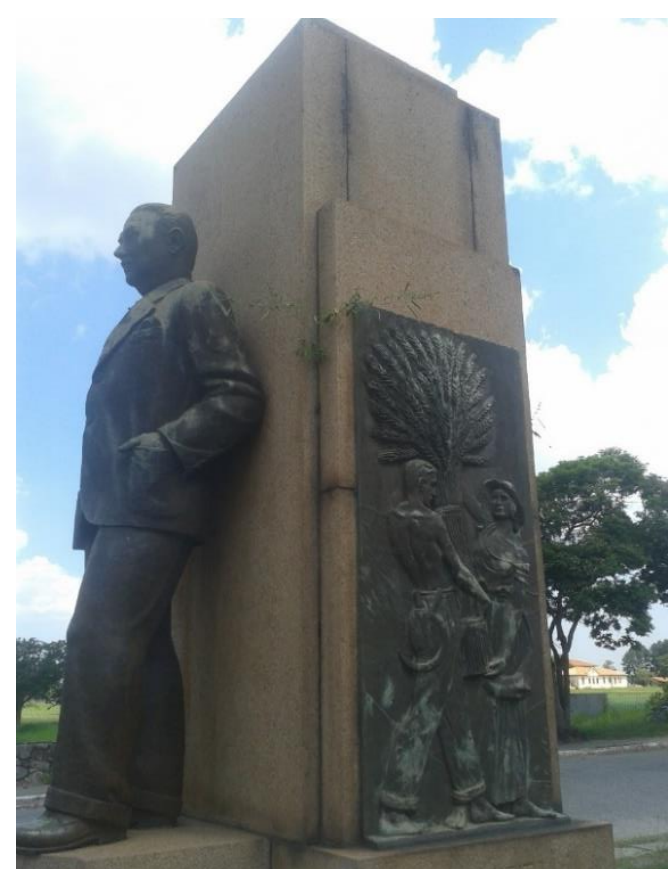

Fonte: autoria própria. mais de quatro quilômetros, enquanto em Seropédica ele apresenta pouco mais de duzentos metros.

Finalmente, gostaríamos de salientar que o desenvolvimento dos territórios de ambas as instituições evoluiu de maneira distinta ao longo do tempo. Em Pirassununga o acréscimo de área construída foi relativamente modesto e a arquitetura se encontra razoavelmente bem preservada. A implantação foi cindida pela Rodovia Anhanguera, mas, com essa exceção, ainda existem vários aspectos do projeto original válidos e visíveis. Em Seropédica o acréscimo de área construída foi relevante, especialmente nos entornos imediatos do

\footnotetext{
188 Em notícias do sítio da internet da Prefeitura do Município verifica-se a inauguração de várias unidades industriais, o que pode vir a alterar esse quadro socioeconômico em médio prazo.
} 
prédio central, que abrigam vários edifícios de moradia estudantil, por exemplo. Há uma área de grandes dimensões ocupada por expansões recentes, ligadas ao Programa de Reestruturação e Expansão das Universidades Federais (REUNI). As áreas habitacionais foram cercadas, gradeadas ou muradas, e a infraestrutura viária para acesso está muito precária, enquanto o restante do sistema está pavimentado. Em Pirassununga a distribuição das antigas áreas habitacionais continua como no princípio: edificações isoladas no meio de áreas ajardinadas, praticamente sem tentativas de divisão física de lotes.

\subsubsection{Areia}

A Escola de Agronomia da Parahyba foi criada pelo Decreto Estadual $N^{\circ} 478$, de 12 de janeiro de 1934, em regime de acordo entre os Governos Estadual e Federal. Situada na região do Brejo Paraibano, na histórica cidade de Areia. Esta cidade tem papel de destaque no estado da Paraíba, abrigando a primeira escola pública construída no estado, do ano de 1822 e o primeiro teatro do estado, do ano de 1859. A escola de agronomia fundada em 1934 pelo acordo das esferas governamentais foi federalizada em 1951, transformando-se na "Escola de Agronomia do Nordeste". É a primeira instituição de ensino superior da Paraíba e pode-se dizer que forma as raízes da Universidade Federal da Paraíba (UFPB), a maior instituição de ensino superior do Estado até hoje. Sua fundação nos anos 30 está vinculada diretamente ao projeto modernizante do governo getulista. Um famoso areiense, o escritor José Américo de Almeida, teve responsabilidade direta sobre a instalação da Escola na cidade de Areia e, mais especificamente, na própria localidade em que se encontra. As instalações da escola foram projetadas e construídas em pouco tempo (dois anos), sob responsabilidade do Ministério da Agricultura, liderado então por José Américo e depois ocupado por Fernando Costa. Seus primeiros docentes foram arregimentados em Viçosa e a escola operou com sucesso cursos de nível fundamental, médio e superior até sua federalização. 189

Em 1955 foi fundada em João Pessoa a UFPB, na época "Universidade da 
Figura 59: Centro de Ciências Agrárias da Universidade Federal da Paraíba.

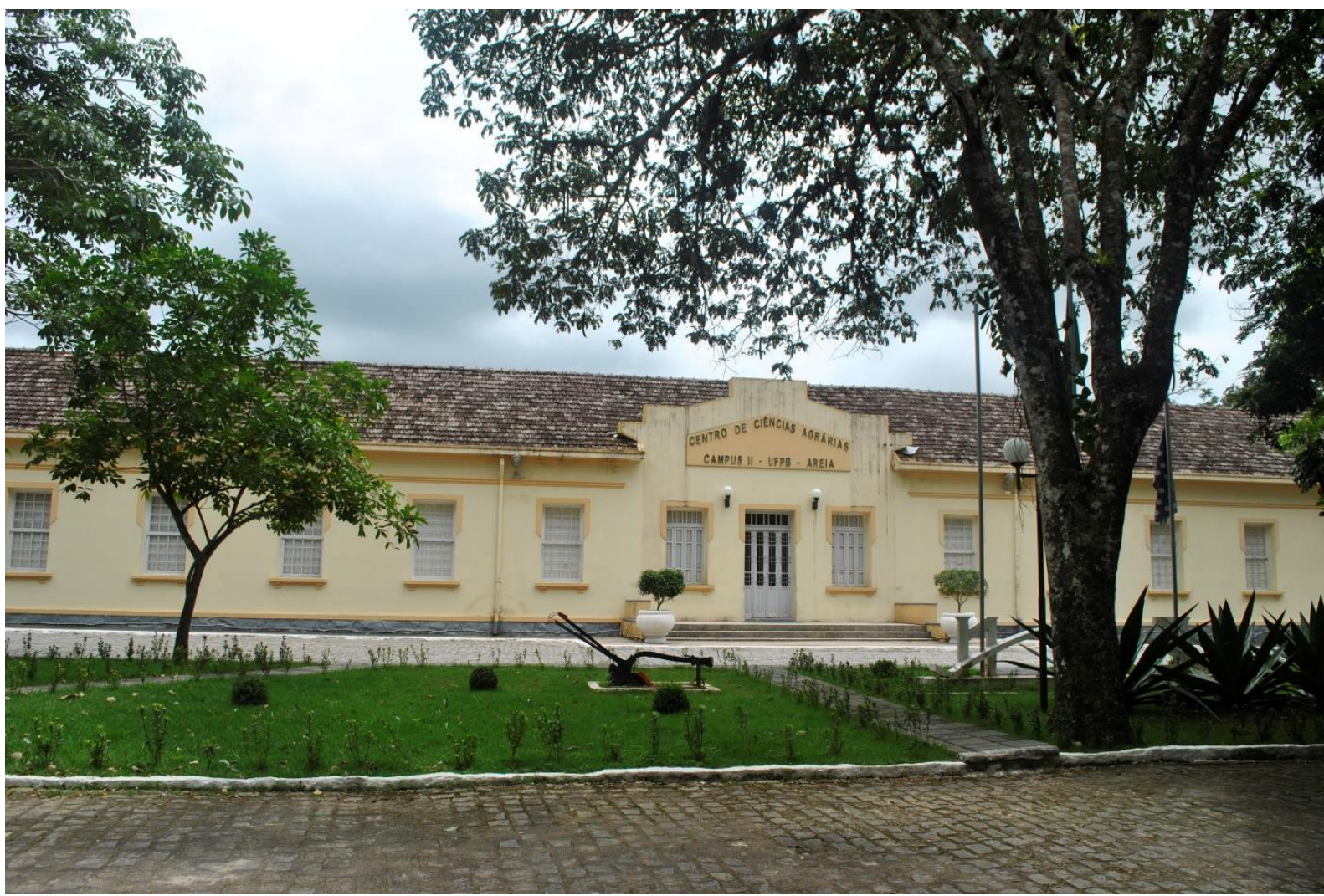

Fonte: https://cliquesportodocanto.wordpress.com/2011/09/11/uma-cidade-na-serra-da-borboremapb-2\%C2\%AA-parte/

Paraíba", quando José Américo de Almeida ocupava a cadeira de governador. Federalizada em 1960, recebe a Escola de Agronomia do Nordeste em 1968, após a reforma universitária. A antiga Escola de Agronomia da Parahyba, após pertencer a centros situados em mais de uma cidade, em 1978 torna-se o Centro de Ciências Agrárias da UFPB (CCA/UFPB), denominação que guarda até os dias atuais. ${ }^{190}$

A cidade de Areia é tombada pelo Instituto do Patrimônio Histórico e Artístico Nacional (IPHAN), desde 2005, incluindo setores do campus da UFPB. Os edifícios que o compõem, especialmente o Prédio Central e o Prédio da Biblioteca, possuem relação arquitetônica com o casario da cidade. O projeto de 1934 tem características coloniais, simplificadas, antecipando o modelo que depois seria utilizado em Belém, de maneira mais intencional (figura 59).

As características físicas do brejo paraibano divergem bastante do interior paulista. Situada na região da Planície Atlântica, possui clima tropical quente e úmido (segundo classificação Koppen), com chuvas no outono e inverno, ocasionadas pelas

\footnotetext{
190 Idem.
} 
massas atlânticas trazidas pelos ventos alísios de sudeste. A precipitação, em média, é bem menor que no litoral ( $600 \mathrm{~mm} / \mathrm{ano}$ contra $1800 \mathrm{~mm} / \mathrm{ano}$ ), porém aumenta nos trechos mais próximos às serras, como é o caso de Areia (que chega a $1400 \mathrm{~mm} / \mathrm{ano}$ ) 191. O solo predominante é o podzólico vermelho amarelo (atual argissolo vermelho amarelo), que apresenta boa adequação à diversas culturas ${ }^{192}$. O terreno é composto por planaltos residuais, com colinas eventuais ${ }^{193}$. A hidrografia é composta por rios e ribeirões de menor porte, a exceção sendo a barragem Saulo Maia, na zona rural situada à leste da cidade (o Campus da UFPB se situa à oeste). A vegetação conhecida como brejo de altitude, composta por disjunções de floresta ombrófila aberta, ainda está presente em várias localidades nos entornos da cidade. No entanto, o uso histórico do solo para produção de açúcar e depois outras culturas já promoveu alterações significativas na maior parte da localidade. A classe de capacidade para uso da terra é "terras íngremes mais suscetíveis à erosão, próprias para cultivos contínuos e que se prestam mais para lavoura esporádica" ${ }^{194}$. O resultado perceptível dessas condicionantes físicas é uma paisagem ondulada, diversificada, com caráter próprio.

Figura 60: Situação do Centro de Ciências Agrárias da UFPB.

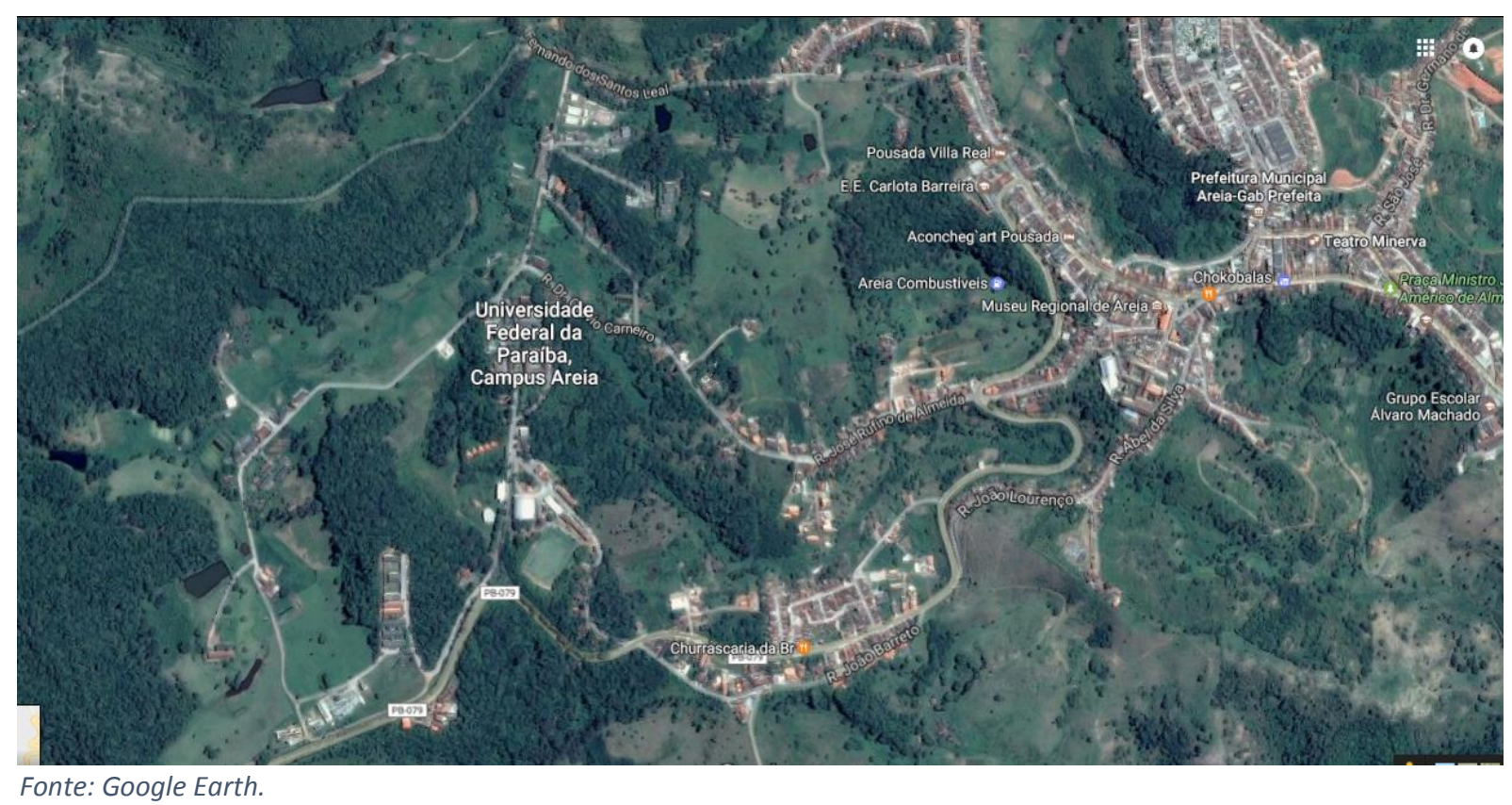

\footnotetext{
191 RODRIGUES (2002).

192 EMBRAPA Solos (1972).

${ }^{193}$ ATECEL (2002a).

${ }^{194}$ ATECEL (2002b).
} 
O campus da UFPB, herdeiro da Escola de Agronomia do Nordeste, ocupa uma área de pelo menos 200 hectares, muito próxima à cidade. A distância entre o prédio central e o centro da cidade é de apenas 2,0 quilômetros. O arranjo urbano do campus não parece ter sido objeto de planos ou projetos intencionais. O prédio central está situado na área central do campus, organizado em quatro alas que formam um quadrângulo ou claustro. Em suas redondezas encontram-se outros edifícios originais. Ao longo das décadas outros edifícios foram construídos ao redor deste centro e nos eixos que partem para a cidade (quatro eixos, um ao norte, um ao leste e dois ao sul). A porção central do campus, edificada, está cercada de matas, e entre estas matas e as montanhas ao redor há áreas de produções experimentais e outros usos. A UFPB responsabiliza-se também pela gestão e manutenção do Teatro Minerva, o primeiro teatro paraibano, que está situado no centro histórico da cidade ${ }^{195}$. É um indicativo de que a relação entre a cidade e o território universitário é intensa (figura 60). Porém há uma nítida e bem convencional separação: nas quatro entradas do campus há portões com guaritas.

O primeiro e inevitável paralelo com Pirassununga tem a ver com a criação de ambas as instituições. Nascidas em cidades do interior, sem qualquer fator de destaque até então, devem sua fundação e início de operação à personalidades políticas que viabilizaram suas existências. Fernando Costa em Pirassununga e José Américo de Almeida em Areia foram personalidades que ocuparam o Ministério da Agricultura e que compartilharam o projeto modernizante getulista, instalando em suas próprias regiões eleitorais as instituições educacionais que representavam o auge deste projeto modernizante (dentro de sua área de atuação). Esse paralelo segue na história das instituições: ambas iniciaram como instituições de ensino fundamental, depois médio e finalmente superior - ainda que em Pirassununga esse caminho tenha sido bem mais demorado. Sendo instituições interioranas de ensino superior, ambas possuem uma certa identidade que se aproxima da cidade em que se situam. 0 caráter rural de suas instalações e o foco no ensino de ciências da terra também são paralelos visíveis. E, finalmente, sua constituição física: enquanto a escola de Pirassununga é um território de vastas dimensões, sua coirmã em Areia é bem menor. As instalações em Pirassununga são também mais sofisticadas, ainda que ambas tenham prédios centrais com maior requinte arquitetônico - e ambos os prédios com 
características da arquitetura neocolonial, o que corrobora a ideia de uma certa identificação entre esta arquitetura e o meio rural. A despeito dos mais de 2.700 quilômetros de separação, a história dessas instituições guarda muitos paralelos.

\subsubsection{Belém}

Figura 61: Universidade Federal Rural da Amazônia.

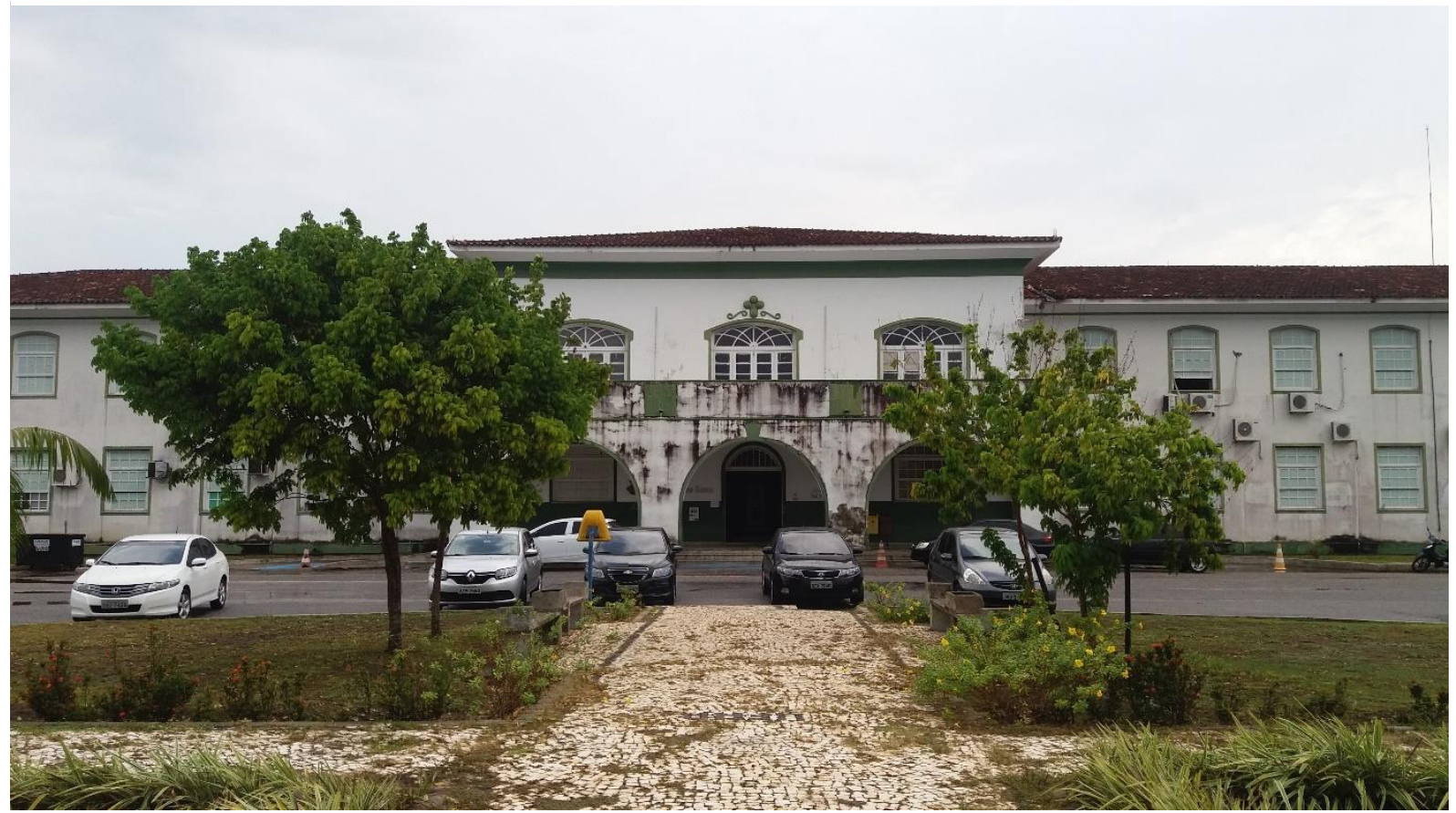

Fonte: autoria própria.

A atual Universidade Federal da Amazônia (UFRA), situada em Belém do Pará, remonta ao antigo Instituto Agronômico do Norte, criado por um decreto de Fernando Costa quando Ministro da Agricultura, em 4 de maio de $1939{ }^{196}$. Seria o primeiro de cinco institutos de pesquisa, mas além deste apenas o do nordeste chegou a ser construído - que hoje é parte do Jardim Botânico de Recife. Sua instalação concluiuse nos anos 40, a partir de projeto aparentemente de Ângelo Murgel, quando este foi funcionário do Ministério ${ }^{197}$. Em 1945 é efetivamente implantada a Escola de Agronomia da Amazônia, que é renomeada em 1972 para Faculdade de Ciências Agrárias do Pará (FCAP) e torna-se Universidade apenas em 23 de dezembro de

\footnotetext{
196 COSTA (1939).

197 LIMA (2013).
} 
2002. O antigo Instituto Agronômico foi projetado com arquitetura neocolonial, bastante simplificada (figura 61), em um local frontal ao Rio Guamá, porém sem vista para o rio, já que as matas ciliares foram preservadas. Ao longo da única via que interliga o prédio principal com a cidade estão distribuídas as áreas de criações, pastagens e experimentos. Desde a fundação da UFRA, em 2002, vários novos edifícios foram implantados ao longo desse eixo, porém o jardim frontal ao prédio principal e o próprio eixo foram preservados. Sobre o projeto original, observamos mais uma vez a aproximação do estilo neocolonial com o ambiente rural, em mais uma obra realizada após decisão política de Fernando Costa. Cronologicamente, esta é anterior à Escola Nacional de Agricultura (a UFRRJ), e talvez isso explique a arquitetura e a implantação mais simples ${ }^{198}$.

A situação física da UFRA é bem diferente das demais instituições apresentadas, especialmente por sua implantação na baixa Amazônia, região que guarda características geográficas bem típicas. O solo aluvial da região, do tipo gleissolo háplico, é ocupado originalmente por matas ciliares (em parte ainda permanece a vegetação original). São solos com pouco oxigênio e muito encharcados, com lençol freático alto e eventualmente inundáveis - o ciclo local é anual, garantido por altas taxas de pluviosidade. A Embrapa atualmente não recomenda a utilização desses solos para qualquer fim, já que são essenciais para a manutenção e perenização dos corpos d'água, apesar de se prestarem para algumas culturas, como arroz e pastagens (de búfalos, especialmente), em casos de estrutura fundiária composta por propriedades pequenas e de subsistência ${ }^{199}$. Além disso, a vegetação original possui muita diversidade e abriga uma fauna igualmente diversificada. O Rio Guamá domina a paisagem, próximo de sua foz no Rio Tocantins, com dimensões que mais lembram uma enorme baía do que um rio ${ }^{200}$. Além desses aspectos físicos, é importante ressaltar que o território está situado em uma capital estadual, que vive uma dinâmica metropolitana e de espraiamento da trama urbana, que já atinge as vizinhanças da UFRA. Essas condicionantes geográficas, em um olhar contemporâneo, poderiam indicar que o local não seria o mais apto para sediar uma instituição de pesquisas e experimentações da área agropecuária.

\footnotetext{
198 Essa correlação é destacada por MASCARO (2008) e por LIMA (2013).

199 SOUZA (S/D)..

200 FAPESPA (2015).
} 
Se as condicionantes geográficas, pelo menos do ponto de vista físico, são muito diferentes entre os casos estudados, do ponto de vista histórico o desenvolvimento das instituições também guarda paralelos. O Instituto em Belém é resultado de uma iniciativa do Ministério da Agricultura no final dos 30 , responsabilizando-se por cursos médios por muitos anos, depois por cursos superiores, até tornar-se um território exclusivamente universitário em 2002. Em Pirassununga, resultado de uma iniciativa do Governo do Estado de São Paulo na metade dos anos 40 - cadeiras ocupadas pelo mesmo personagem - a evolução foi parecida, tornando-se um espaço exclusivamente universitário em 1989. A arquitetura neocolonial também as une, mas a implantação e a relação com a cidade são bastante diferentes. A implantação do antigo Instituto é extremamente simples, tendo como único elemento de atenção especial o jardim defronte a entrada do prédio principal, ao passo que a Escola de Pirassununga foi objeto do projeto de um parque. E, finalmente, a atual UFRA é um território murado com uma portaria, que pouco se relaciona com a metrópole que a cerca. Os bairros do outro lado da avenida são extremamente precários (figura 62). Questionados, estudantes e funcionários da UFRA nos informaram que não frequentam esses bairros.

Figura 62: Implantação da Universidade Federal Rural da Amazônia.

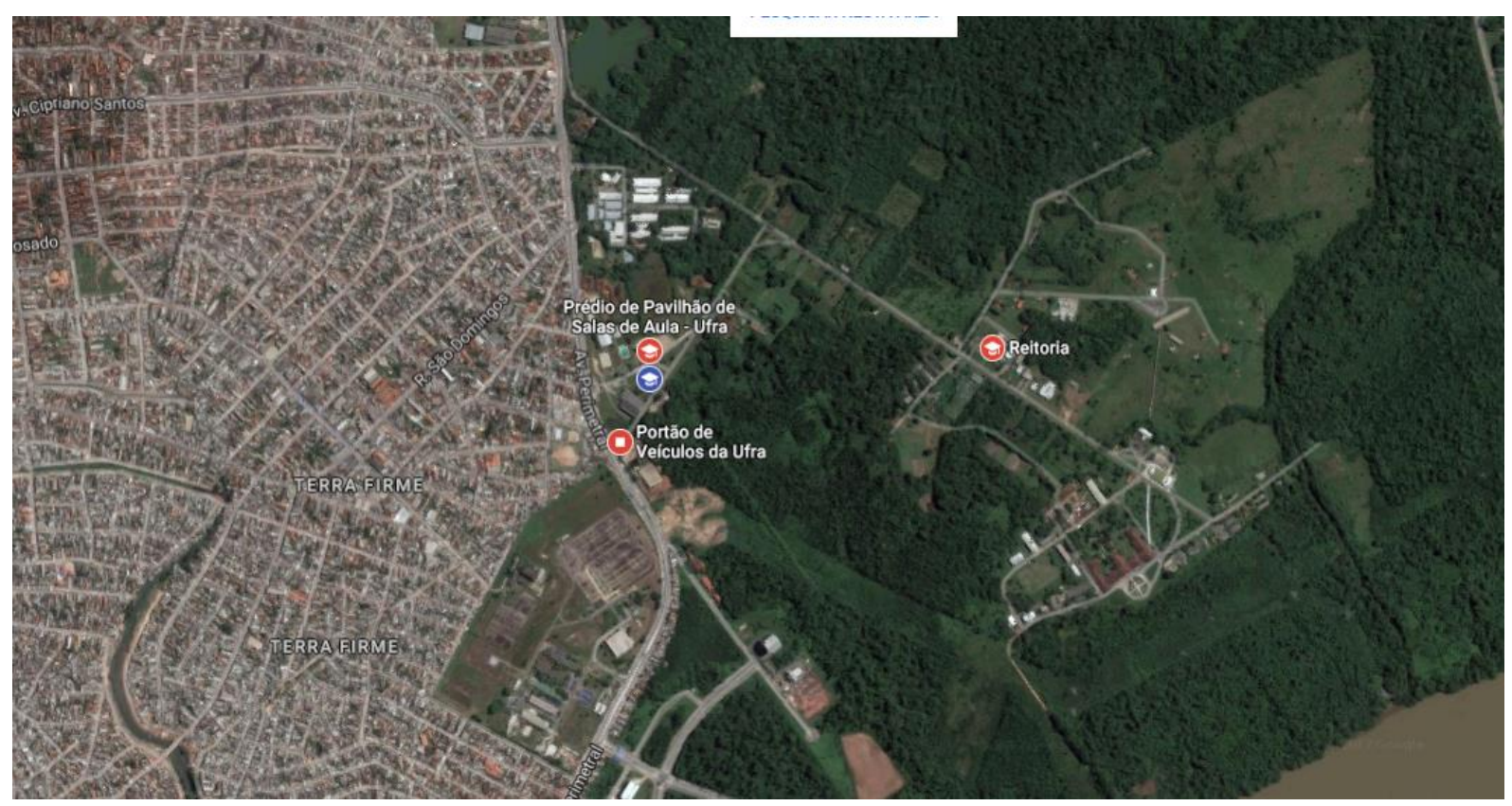

Fonte: Google Earth. 


\section{CAPÍTULO 3}

\section{Progresso, crise e a chegada gradual da Universidade}

Este capítulo relata a sequência dos fatos que ocorreram no que é hoje o Campus Fernando Costa da USP e suas relações, tanto com a cidade, quanto com a institucionalidade, além de questões relacionadas à gestão do território. O período de progresso e a subsequente crise, que se anuncia nos anos 1950, tem origens plantadas ainda nos últimos anos da década anterior. Na primeira metade da década o projeto é radicalmente alterado pela construção da via Anhanguera, uma violência na paisagem, como denominamos. Em 1956 a Escola Prática de Agricultura é fechada.

A seguir o capítulo trata do ponto de vista político nos anos 50 , quando o conservadorismo se encontrava em alta em SP e isso interfere diretamente na continuidade da história destes projetos educacionais. As idas e vindas institucionais refletem a preponderância das decisões administrativas no gerenciamento do espaço físico. O seguinte título trata da chegada da USP em Pirassununga e a gestão desse território como, efetivamente, espaços universitários. A relação entre a escola técnica vinculada à USP (e também o posterior campus universitário) com a cidade é assunto para este capítulo.

A mudança de nome enseja a discussão etimológica sobre o termo "territórios universitários", importante para a inserção deste trabalho em um corpo maior que tenta entender essa categoria espacial. Finalmente, observamos como as decisões institucionais causam impactos na paisagem, com foco nos acontecimentos após a transformação da antiga fazenda em campus universitário. E o último título deste capítulo refere-se ao Campus Fernando Costa como parte da USP atual. 


\subsection{O ocaso do ensino agrícola e o projeto de industrialização do campo}

A crise que conduziria ao fechamento da Escola Prática de Agricultura tem suas origens plantadas ainda nos últimos anos da década anterior, pouco tempo decorrido da inauguração.

Nos seus primeiros dois anos, as Escolas recebem grande reconhecimento 201. Porém, mesmo sendo instituições recém-inauguradas, as Escolas Práticas de Agricultura rapidamente sofrem uma degradação física e um abandono institucional. Em primeiro lugar, por causa do falecimento de Fernando Costa, o maior defensor daquele projeto de educação do homem do campo. Em 21 de janeiro de 1946 ocorre um acidente de trânsito no qual falece o pré-candidato ao governo do Estado de São Paulo ${ }^{202}$. Suas ideias são defendidas por várias figuras da política da época, como se percebe nos Relatórios Oficiais da Secretaria de Agricultura e no apoio aos discursos publicados de Fernando Costa ${ }^{203}$. Mas esse apoio não encontrava eco nas disputas de poder das esferas mais altas da política estadual e nacional.

Com sua morte, superpõe-se o discurso dos defensores de outras políticas para o campo, mais objetivas e desvinculadas da questão educacional (ou apenas vinculadas à educação de nível superior). Os grupos liberais que ascenderam ao poder possuíam visão mais conservadora da modernização, preferindo investimentos Figura 63: Escola Prática de Agricultura nos anos 1950, em processo de degradação física.
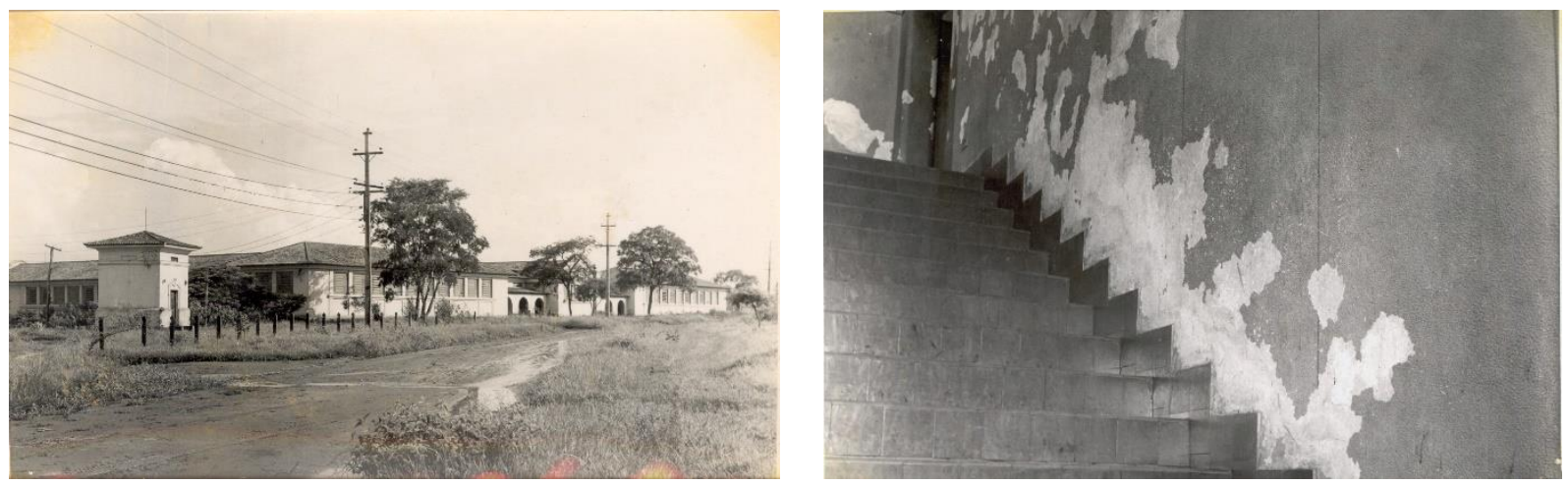

Fonte: acervo FZEA.

201 SAAESP (1946), pg. 144.

202 Diferentes fontes afirmam que o acidente ocorreu na Via Dutra (TELES e IOKOI), ou na estrada que conduzia à São Paulo (BRAGAGNOLLO).

203 COSTA (1939), COSTA (1942). 
vinculados ao capital internacional, ou iniciativas com enfoque puramente econômico e produtivo, sem consideração com a questão educacional ${ }^{204}$. Para a efetiva formação do homem do campo, a proposta vencedora nos anos 50 encontrou base legal com as Leis Orgânicas do Ensino Primário e do Ensino Normal, que preconizava a educação técnica no campo apenas nos níveis médio e superior, enquanto a formação profissionalizante específica ficaria à cargo das próprias empresas ${ }^{205}$.

Em segundo lugar, ainda interligado ao primeiro, as vozes que atacavam o projeto passaram a ser predominantes na mídia e na política da época. As escolas eram consideradas "caras", tanto quanto à manutenção, quanto ao custo para formação de um homem que terminaria por não se afixar no campo como trabalhador braçal, mas se deslocaria para a cidade, já que estaria "acostumado com os benefícios da civilidade!"

Um dos objetivos do projeto, de fato, era oferecer aos alunos uma educação que ultrapassasse as questões técnicas. As questões de higiene e hábitos sociais eram importantes na formação oferecida, para a efetiva superação do modo de vida precário que predominava no interior do Estado e do país ${ }^{206}$. Mas seus detratores diziam que este egresso não retornaria ao campo, já que estaria acostumado com estes benefícios típicos da vida urbana e raríssimos ou inexistentes no espaço rural daquele período histórico ${ }^{207}$. Portanto o impacto desejado teria efeito nulo na efetiva transformação do campo. Como veremos adiante, essa crítica permanece e também se aplicará ao IZIP e ao CIZIP, em seus cursos médios.

Em terceiro lugar, a ideia corrente em São Paulo era que neste Estado, a "locomotiva do desenvolvimento econômico nacional", só havia espaço para a indústria ou atividades a ela associadas. Nessa ótica, importava mais a mecanização do campo do que a formação do trabalhador rural.

Essas três condições, mais a ascensão do grupo político liderado por Ademar de Barros e Jânio Quadros, causariam o ocaso do projeto criado e defendido por Fernando Costa.

\footnotetext{
204 QUEDA e SZMRECSÁNYI, apud TELES e IOKOI (1996), pg. 83.

205 TELES e IOKOI (1996), pg. 84.

206 COSTA (1944).

207 O Movimento.
} 
Em 1956 a Escola Prática de Agricultura é fechada - mas ao mesmo tempo a comunidade de professores e estudantes da medicina veterinária da USP já se movimentava para sua reabertura em outros moldes.

No caso específico de Pirassununga esse período de crise também se refletiu no espaço físico da Escola. O espaço encontrava-se "caindo aos pedaços", como se um esqueleto fosse (figura 63), conforme depoimento de Maria Ferri Soares Veiga 208. Alguns equipamentos estavam simplesmente encerrados, como a apicultura. Essa produção ajudava inclusive na sobrevivência institucional (ideia, aliás, defendida por Fernando Costa), já que o mel produzido era vendido no comércio da cidade e nas redondezas. A manutenção da infraestrutura era precária e o número de alunos, ano a ano, se reduzia 209 .

3.1.1. A primeira transformação da paisagem: construção da Via Anhanguera.

A degradação do espaço físico, causada pela manutenção insuficiente, foi agravada por uma obra de enorme impacto na paisagem. Na primeira metade da década de cinquenta aconteceu a construção e inauguração da Via Anhanguera, o caminho que interliga o centro-oeste do país com a capital paulista ${ }^{210}$. A estrada foi construída à oeste da cidade, passando exatamente no meio do território ocupado pela Escola Prática de Agricultura.

O traçado original da antiga estrada que interligava as mesmas cidades, em terra, e pré-existente à aquisição das glebas para a implantação da antiga Escola Prática, passava por dentro da cidade de Pirassununga. Em depoimento de Noé Masotti para Teles e lokoi ${ }^{211}$, o professor afirmava que a antiga pista passava pelo centro de Pirassununga, pela Rua Duque de Caxias e seguia em linha reta rumo a Porto Ferreira. Este eixo é onde hoje está a Avenida Duque de Caxias Norte. As terras que compõem o território da Escola estão margeando esse eixo, no sentido do poente.

\footnotetext{
208 TELES e IOKOI (1996), pg. 88.

209 Id, pg. 83.

210 REIS (2014), pg. 91.

211 TELES e IOKOI (1996), pg. 73.
} 
A nova rodovia atravessaria o território da Escola, cindindo-o em duas partes (figuras 64 e 65). $O$ eixo central, com pouco mais de 5 quilômetros de comprimento, foi cortado pouco após quilômetro " 3 ". O resultado foi a completa descaracterização do trecho apresentado como Parque no capítulo anterior.

As rotatórias junto ao antigo Ginásio de Esportes e junto ao trevo da área produtiva foram eliminadas. O Ginásio de Esportes passou a ser margeado por uma estrada lateral, com acesso pela área produtiva e nenhuma interligação com as áreas de habitação e alimentação dos alunos. Seu isolamento gradual causou seu esquecimento e o fechamento do prédio nos anos 70 (só reaberto em 2011, com outra função). A outra rotatória, de acesso à área produtiva, foi parcialmente eliminada. 0 acesso à área produtiva passou a ser realizado por uma nova estrada (atualmente denominada "Estrada do Povo"), que se inicia no Eixo Central pouco antes do cruzamento (na época, em nível), com a Rodovia Anhanguera. A antiga rotatória, desfigurada, serve até hoje como via de acesso a alguns edifícios, atualmente ocupados pelo Setor de Segurança da Prefeitura do Campus e pelo Centro de Pesquisa em Toxicologia Veterinária do Departamento de Patologia Veterinária (CEPTOX/VPT).

A lagoa que possuía a maior área no projeto original do Parque sofreu assoreamento, tornando-se um charco. Passaria a ser conhecida como "Lagoa Seca", nome que identifica o local até hoje. Seu assoreamento causou o bloqueio parcial e o mau funcionamento da pequena estação de tratamento de esgotos que ali funcionava, atendendo ao Prédio Central (a estação ainda existe, mas não funciona).

Permaneceria, no entanto, o eixo principal, que dá sentido e interliga todas as regiões da área estudada. Porém, no cruzamento deste eixo com a Rodovia, é construído um portal, em estilo modernizado (art decó), pouco coerente com o neocolonial pré-existente. Encontramos uma única imagem deste portal, que teve vida curta, já que será demolido na obra de duplicação da rodovia, nos anos 70 . 
Figura 64: Indicação da área ocupada pela Via Anhanguera.

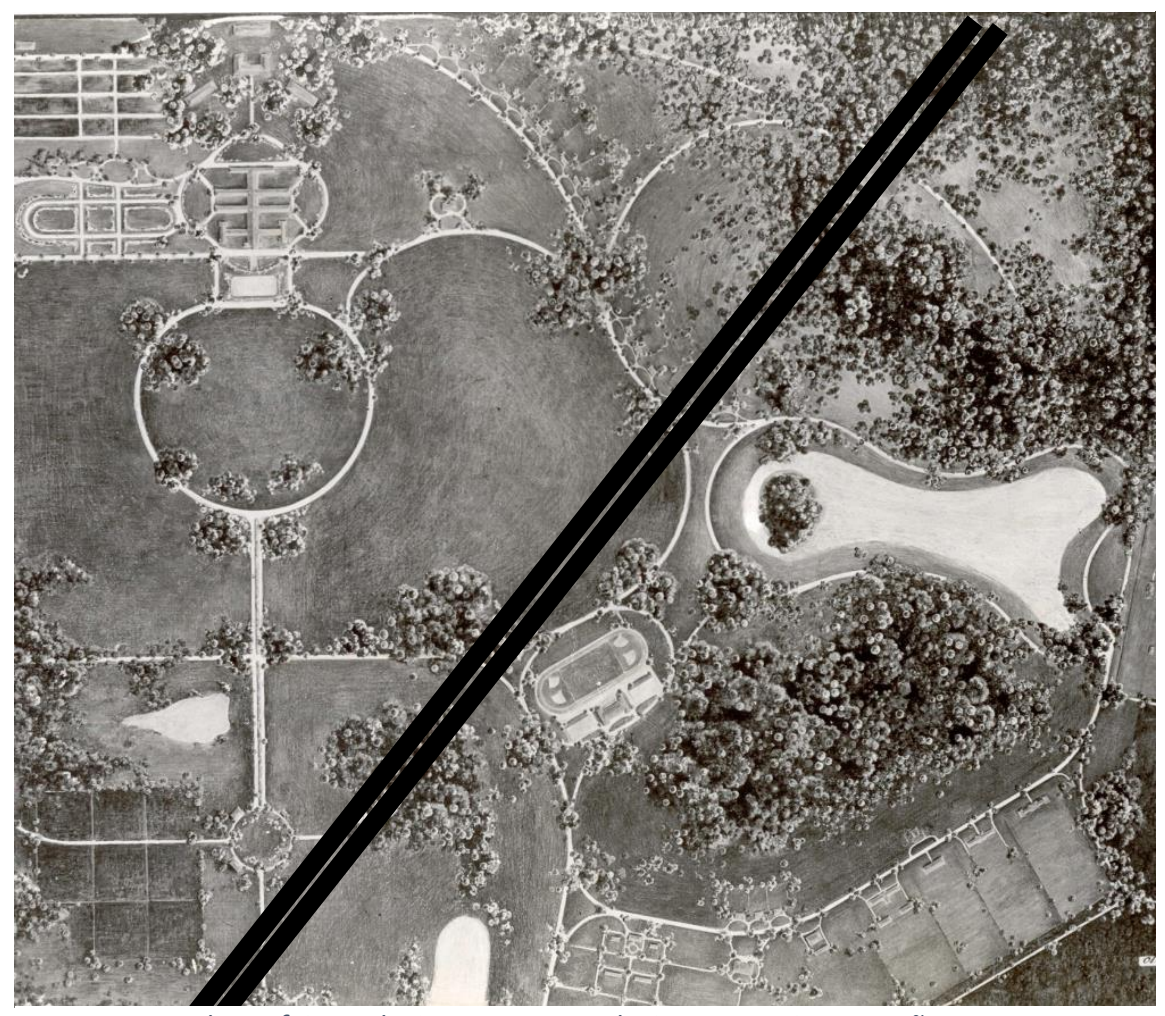

Fonte: Acervo da Prefeitura do Campus Fernando Costa, com intervenções.

Figura 65: Imagem orbital atual do recorte anterior.

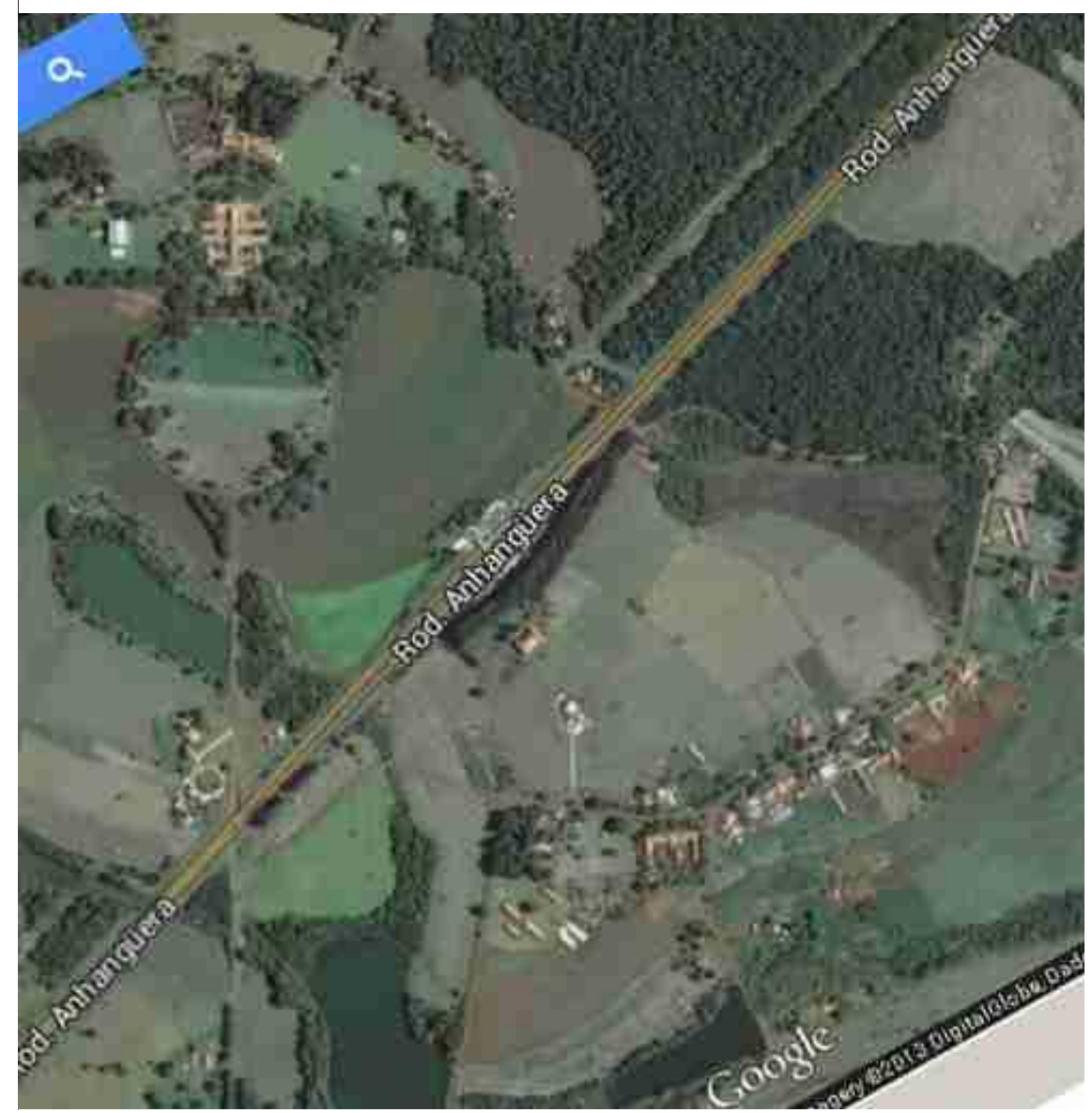

Figura 28: Imagem atual do recorte anterior. 
Esse fato foi a primeira grande transformação da paisagem, com impactos bastante significativos sobre a implantação original. Curiosamente, uma publicação oficial da Universidade não considera essa alteração algo relevante, que mereça mais do que uma citação, aceitando que "na prática, não descaracteriza a implantação inicial" 212 .

\subsection{Escola técnica e a sociedade nos anos 50 a 70}

Nos anos 50 o perfil político predominante em São Paulo era mais conservador. O projeto modernizante dos grupos políticos no poder tinha em seu bojo conteúdos mais ligados às questões produtivas e econômicos e não dedicava à educação um papel central. As críticas ao projeto educacional de Fernando Costa partiam principalmente dos grupos tradicionalistas udenistas (partidários da União Democrática Nacional, a UDN, partido da direita tradicional), que eram adversários do PSD (partido de Fernando Costa), como seria de se esperar. Porém haviam críticas dentro do próprio PSD. Em discurso de 1951, recuperado por Luciana Mascaro, o deputado Antônio Furlan, do PSD, tece uma pesada crítica sobre as Escolas Práticas de Agricultura, enfocando o caso da escola de Ribeirão Preto. Apresentando os argumentos aos quais nos referimos no título anterior, o Deputado considera a manutenção das escolas um desperdício de dinheiro público e propõe seu fechamento 213. Basicamente, o mesmo conteúdo da crítica udenista. Não encontramos manifestações provenientes dos partidários do PTB (Partido Trabalhista Brasileiro), que possuía posturas mais progressistas naquele tempo. Também não encontramos manifestações de partidários do PCB (Partido Comunista Brasileiro), que - mesmo estando sem registro nos anos 50 - tinha grande apoio popular e também posturas mais progressistas.

Essa situação colaborou com a perda de prestígio das Escolas Práticas de Agricultura, como vimos. Progressivamente foram destinadas a outros usos. A escola de Ribeirão Preto tornar-se-ia um campus da USP, abrigando a Faculdade de

\footnotetext{
212 CPC (2005), pg. 185.

213 MASCARO (2008), pg. 107. No texto a autora cita "Aníbal Furlan”, porém o deputado se chamava Antônio Furlan (verificado na lista de deputados de cada legislatura, junto ao sítio da internet da Assembleia Legislativa de São Paulo).
} 
Medicina e depois várias outras unidades - hoje estão ali aproximadamente um sexto dos estudantes e professores da USP 214. A Escola de Itapetininga, fechada no começo dos anos 50 , se tornou um presídio agrícola. Nos anos 70 voltaria à sua função original - em nível médio, com o nome de Escola Técnica Agropecuária Estadual Prof. Edson Galvão. Hoje mantém a função, com o prenome de "Escola Técnica Estadual - ETEC". A escola de Guaratinguetá foi cedida à União em 1950 e transformada em Escola de Especialistas de Aeronáutica ${ }^{215}$. Funcionou como tal desde 1954 até meados dos anos 90. Depois foi transformada em Escola Média, ligada ainda à Aeronáutica, função que ocupa até hoje. A escola de Bauru foi transformada em presídio agrícola em 1955, um presídio em sistema semiaberto que abriga 1190 presos (ainda que tenha capacidade oficial para apenas 500) ${ }^{216}$. Atualmente é denominado Centro de Progressão Penitenciária Prof. Noé de Azevedo. A escola de São José do Rio Preto nem chegou a funcionar. Por ser a última a entrar em período de obras, ainda não estava concluída quando Fernando Costa faleceu. No começo dos anos 50 já é destinada para abrigar um presídio agrícola, sem sequer abrir sua primeira turma. Hoje é o Centro de Progressão Penitenciária Dr. Javert de Andrade, que comportaria 1079 presos, mas abriga $1897{ }^{217}$. Finalmente, as escolas de Amparo, Presidente Prudente, Araçatuba e Marília nem chegaram a ser construídas.

A escola de Pirassununga também seria destinada à USP, porém para abrigar cursos de nível médio, sob os cuidados da Faculdade de Medicina Veterinária, já a partir de 1958 (após a Lei 1763 de novembro de 1957). Em maio de 1958 o governador Jânio Quadros visita o IZIP (figura 66). Eleito

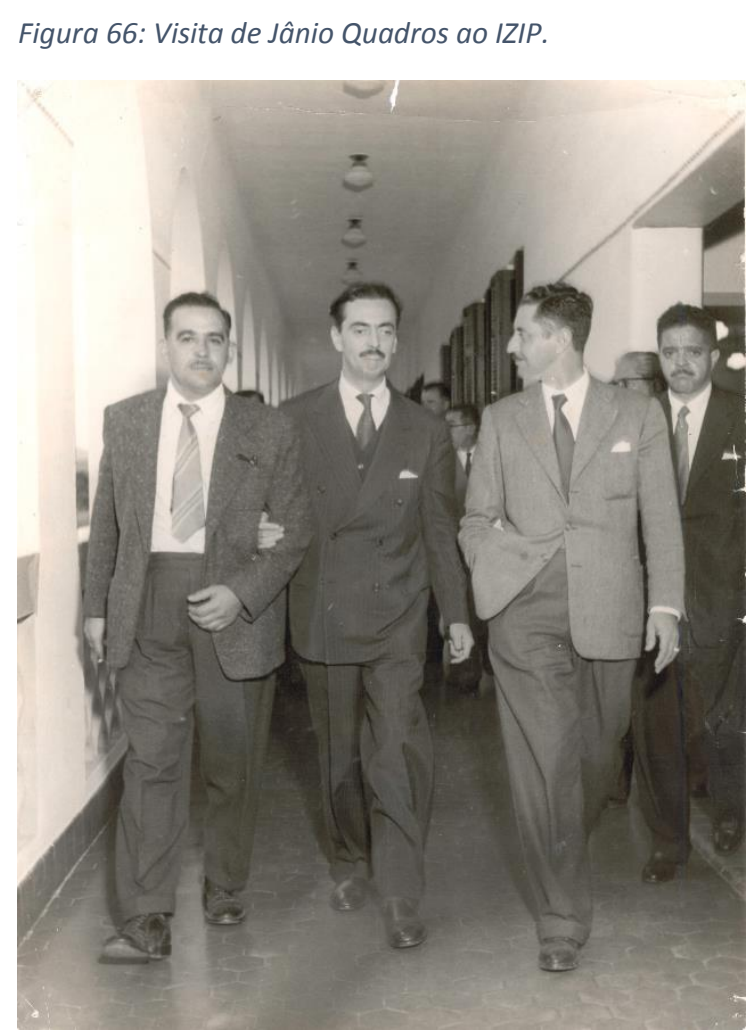

Fonte: Acervo FZEA.

\footnotetext{
214 USP em Números 2015.

215 MASCARO (2008), pg. 104-105.

216 http://www.sap.sp.gov.br/common/unidprisionais/crn/ipa_bauru_prof_noe_azevedo.html

217 http://www.sap.sp.gov.br/uni-prisionais/cpp.html\#
} 
por um partido relativamente pequeno (o Partido Democrata Cristão, PDC), porém com apoio do PSB (Partido Socialista Brasileiro), realizou um governo de posições dúbias, ora se aproximando de posicionamentos mais progressistas, ora conservadores. Seu projeto de modernização que tentaria aplicar no país, ao se eleger Presidente da República pouco tempo depois, era economicamente conservador e ligado aos interesses do capital internacional, porém ao mesmo tempo propunha avanços e benefícios para a classe trabalhadora ${ }^{218}$. Antes, como Governador do Estado, Jânio Quadros propôs o decreto que inaugurava cursos de nível médio na Escola Prática de Agricultura em Pirassununga, organizados em um Instituto subordinado à Universidade de São Paulo. Portanto, ao mesmo tempo em que o processo de degradação chegava ao seu ponto máximo, com o efetivo fechamento da escola e a degradação do espaço físico, se abria a esperança, tanto da continuidade de um projeto educacional quanto à manutenção daqueles espaços.

Simultaneamente à instalação do Instituto de nível médio, alguns estudantes da Faculdade de Medicina Veterinária (então apenas FMV, sem o "Z" de Zootecnia) se organizavam para pleitear para sua unidade a área da recém-fechada Escola Prática de Agricultura. A infraestrutura da unidade, então sediada no bairro da Aclimação, próximo ao centro da capital de São Paulo. A formação em produção animal era deficitária e realizada em instalações inadequadas. Com a instalação do Instituto de nível médio, sob os auspícios da USP, abria-se o caminho para parte da formação em medicina veterinária ser realizada em Pirassununga, em instalações adequadas. Ainda em 1957 o Departamento de Produção Animal da FMV se dividiu em dois: os professores interessados na área de produção seriam transferidos para Pirassununga, enquanto que os professores interessados na área de nutrição animal seguiriam em São Paulo ${ }^{219}$. Alguns anos mais tarde, já transferidos para a Cidade Universitária, também ocupariam alguns espaços em Pirassununga. Os professores que se mudaram para Pirassununga foram minoria, mas ainda assim o Departamento foi efetivamente implantado e futuramente daria origem ao curso superior de Zootecnia, integralmente ministrado em Pirassununga. As instalações físicas do curso superior e dos cursos médios eram compartilhadas. Depoimentos registrados por Teles e lokoi e até hoje repetidos pelos ex-estudantes do período remetem a um

\footnotetext{
218 PAULA (2004).

219 TELES e IOKOI (2005), pg. 89-90.
} 
período de grande relevância da escola, durante o qual a convivência com a sociedade pirassununguense floresceu 220.

A transferência da Escola em Pirassununga para a USP permitiu, além da sobrevivência do local como espaço educacional, a manutenção dos espaços físicos, ainda que algumas vezes com cuidados insuficientes. As instalações físicas não sofreram ampliações no período. Não há edifícios novos construídos no período em que o território estudado se denominava IZIP. Porém alguns edifícios tiveram alteração de uso. O edifício João Soares Veiga (nome do fundador do IZIP), que abrigava enormes laboratórios de produção de alimentos foi dividido com um corredor central, em algum momento dos anos 1970, com empréstimos do Banco Interamericano de Desenvolvimento (BID) ${ }^{221}$. A partir dos anos 90 sofreu algumas ampliações, com salas de aula novas, ocupação e fechamento das varandas, pequenas expansões em seus limites, construção de mezaninos, etc. A fachada frontal continua íntegra, porém todo $o$ interior e as demais fachadas estão complemente descaracterizados. O Clube de Campo tornou-se um Centro de Eventos (função que segue até hoje). A antiga escola tornou-se Hospital Veterinário, antes abrigando aulas didáticas. Mais recentemente mudou-se a denominação para Centro de Apoio ao Ensino, Pesquisa e Extensão (CAEPE). Depois da profunda alteração da paisagem causada pela construção da Rodovia Anhanguera, nas décadas de 1950 e 1960 não foram realizadas mais obras de impacto que causassem novas alterações na paisagem.

Os cursos técnicos, inaugurados poucos anos antes sob a denominação "Instituto de Zootecnia e Indústrias Pecuárias Fernando Costa", ou IZIP, foram renomeados para CIZIP, ou "Centro Intraunidade de Zootecnia e Indústrias Pecuárias Fernando Costa", passando de nível ginasial para médio.

Assim sobreviveu até os anos 1970, quando foi inaugurado o primeiro curso de nível superior, de zootecnia. Durante esses pouco mais de vinte anos o ensino profissionalizante agrícola não apenas se justificava economicamente, como também foi alvo de grande procura. A aproximação da formação oferecida com as necessidades das empresas era muito bem vista pelos governos conservadores, ao

\footnotetext{
220 Id., cap. 5.

${ }^{221}$ ALBUQUERQUE e GHION (2007), pg. 19.
} 
contrário dos modelos emancipadores criados por Fernando Costa. A mesma discussão se coloca na formação superior, em Medicina Veterinária. Enquanto parte da formação era feita nos moldes preconizados pelos fundadores da USP, com o pensamento elitista de formação de um corpo dirigente ilustrado, outra parte se adequava às novas exigências, interligando a escola com as empresas (modelo hoje em alta na USP), proporcionando formação de fundo tecnicista ${ }^{222}$, que prepara os técnicos altamente capacitados para operacionalizar o capital. Essa ideologia se tornaria a predominante, pois estava ligada à pressão internacional pela ampliação do ensino superior no Brasil - vinculada aos empréstimos do BID - e a vontade política do novo governo ditatorial pós-64 em ampliar o acesso ao ensino superior ${ }^{223}$.

\subsubsection{A relação entre Pirassununga e a escola técnica (IZIP / CIZIP).}

Nas décadas de 1950 e 1960 o IZIP, escola técnica vinculada à USP, formou 15 turmas nos cursos técnicos de "indústrias agropecuárias" e "zootecnia". Recentemente foi urbanizada uma pequena praça, nas proximidades do prédio central, para homenagear e relembrar essas turmas e a comunidade da época (professores e funcionários). Em depoimentos informais, os ex-estudantes do período demonstram grande carinho pela instituição e relevam a grande identidade com o território, identificando certos recortes físicos com "apelidos", como também faziam com as pessoas.

A cidade utilizava os espaços do IZIP, especialmente o atual Centro de Eventos, que na época era chamado de "Clube de Campo" (figura 67). Neste local aconteciam as formaturas, as recepções às autoridades, como reitores, políticos de repercussão estadual, membros da lgreja e os eventos de maior formalidade ${ }^{224}$.

O Parque de Exposições foi o último conjunto de construções a ser concluído no período de fundação da escola, ainda nos anos 1940. Era centralizado por uma área gramada ovalada, cercada, onde os animais se expunham. O terreno possui

\footnotetext{
222 TELES e IOKOI (2005), pgs. 103-110.

${ }^{223}$ Essa passagem é muito bem explicada por FARIA (2001), pgs. 169-172.

224 Id. pg. 93.
} 
inclinação

de

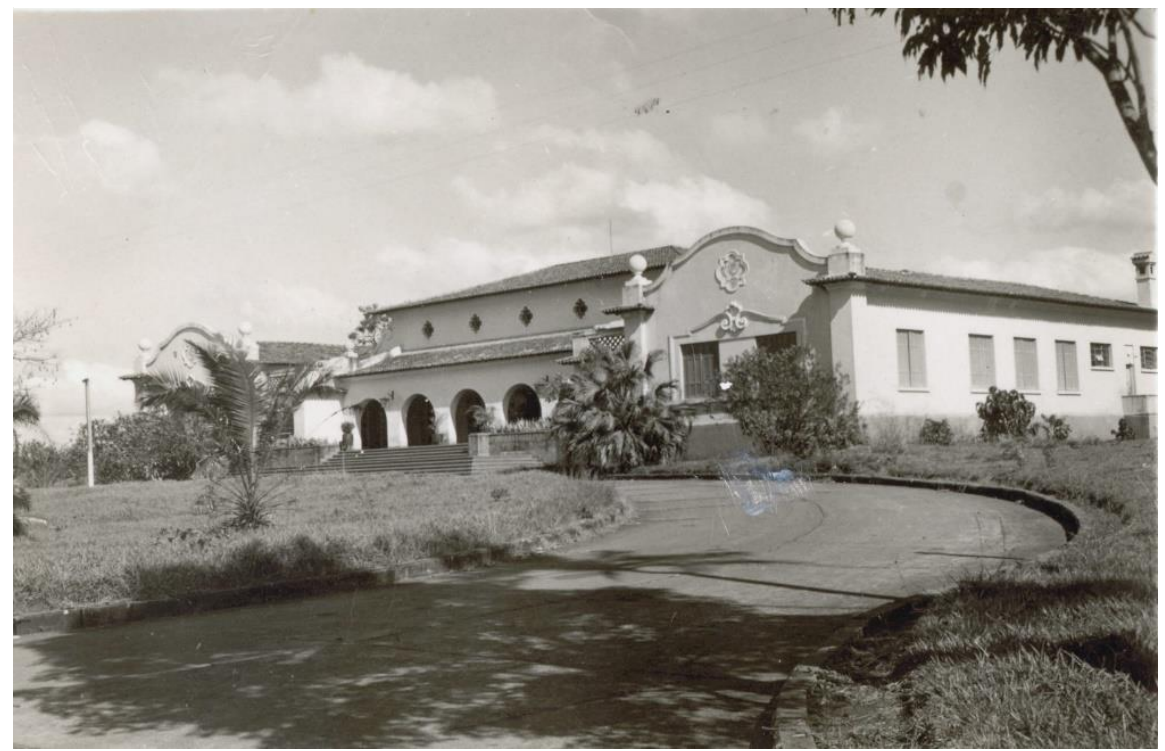

aproximadamente $5 \%$ e na cota mais alta foi construído o edifício denominado “arquibancada”. Além desta função, esse edifício possuía, na parte posterior, áreas de apoio, como banheiros, copa e depósito. $\mathrm{Na}$ parte frontal, além da arquibancada (com capacidade estimada em 300 pessoas), há alguns platôs onde bandas musicais e principalmente duplas sertanejas se apresentavam. A dinâmica da época, conforme depoimentos informais, era muito simples: os eventos começavam com a apresentação dos animais, durante a qual o público assistente permanecia sentado e parte dele em área coberta e sombreada. Depois o público descia da arquibancada e postava-se diante dela, portanto curiosamente o espaço tornava-se um palco (figura 68).

Os estudantes, quase todos, residiam na própria escola, nas oito alas habitacionais do Prédio Central. Nesse período se iniciaram as obras nestas alas habitacionais, que foram projetadas originalmente como um grande quarto coletivo

Figura 68: o Parque de Exposições atualmente.

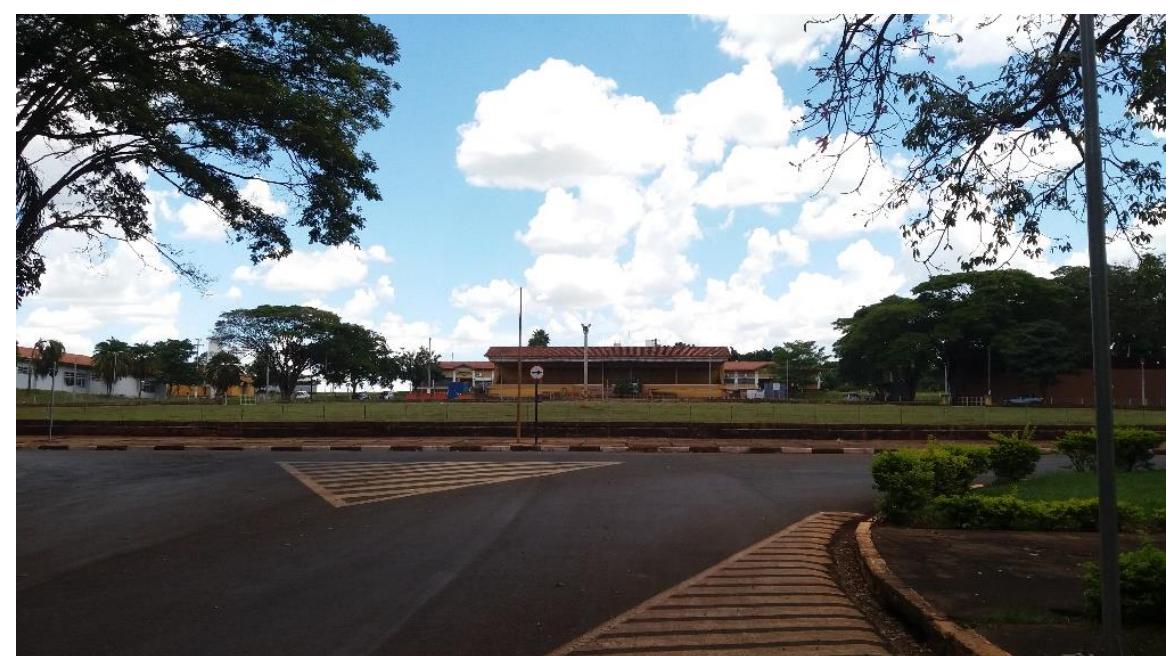

Fonte: autoria própria. (para abrigar 50

alunos cada), interrompidos apenas por uma saleta do bedel em cada ala (figura 69). Com as alterações, foram criadas diferentes tipologias: quartos coletivos para 2, 3, 4 e 6 
Figura 69: Alas residenciais antes das reformas.

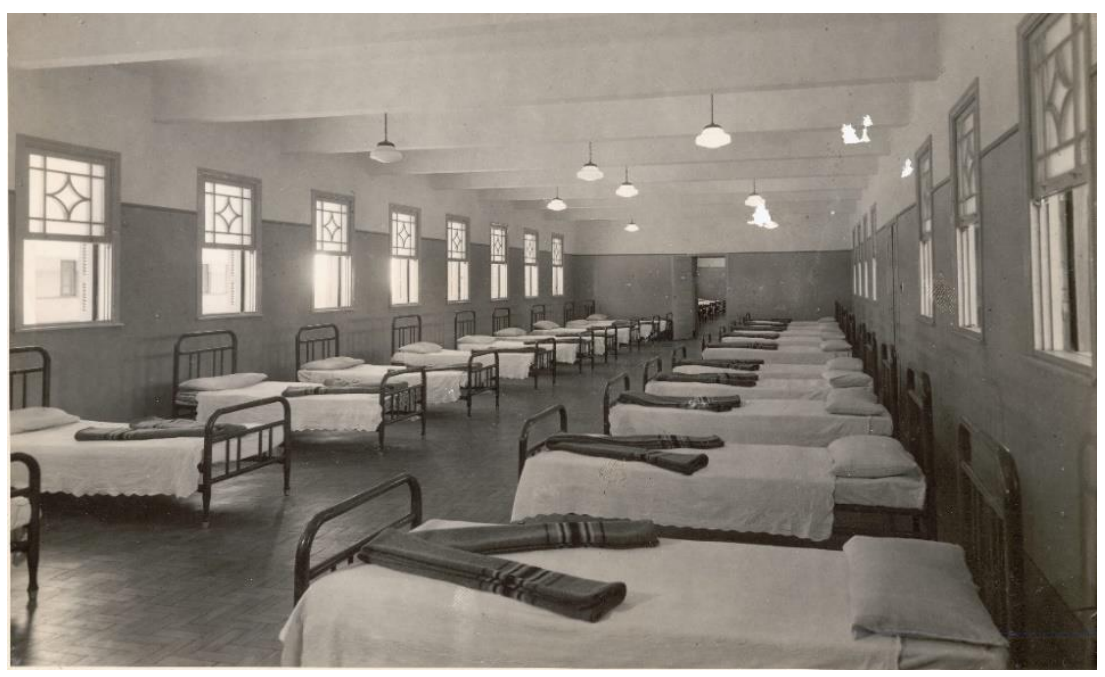

Fonte: Acervo FZEA. pessoas. Não foi possível determinar com precisão quando a reforma de cada ala foi executada, nem quantas reformas foram realizadas em cada ala.

Haviam intensas relações entre as comunidades do município e do IZIP /

CIZIP. Os estudantes eram provenientes de todas as regiões do país e, inclusive, do exterior. As instalações esportivas existentes facilitavam o intercâmbio, já que ali ocorriam competições que reuniam as escolas da cidade, além dos times da aeronáutica e do exército. $O$ espírito progressista que vicejava na escola influenciava

Figura 70: Imagem aérea de Pirassununga em 1955.

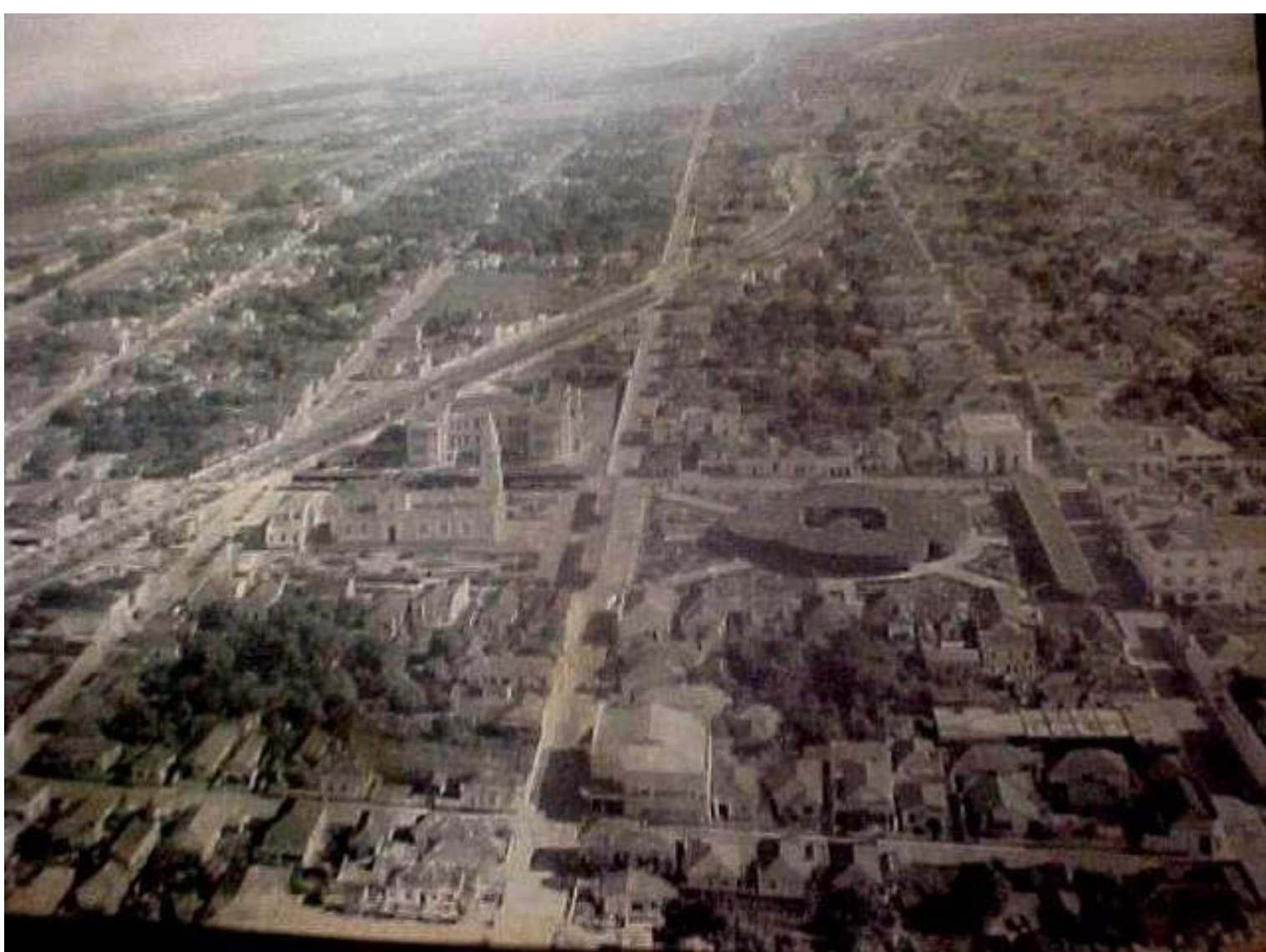

Fonte: http://memoriadepirassununga.blogspot.com.br/ 
a cidade. Era o palco privilegiado da liberdade política e do debate ideológico, passando praticamente incólume no período repressor da ditadura militar brasileira 225.

Essas relações sociais aconteciam com frequência e eram facilitadas pela pequena distância entre a escola / universidade e a cidade. Ainda que esta permanecesse situada em situação rural, estava relativamente próximo da trama urbana (precisos 1,6 quilômetro da praça central da cidade até a portaria) ${ }^{226}$. A Estrada de Porto Ferreira, atual Avenida Duque de Caxias Norte, via frontal e de acesso à escola, já estava parcialmente pavimentada, com exceção dos últimos seiscentos metros (figura 70). Os loteamentos mais próximos ao centro são vistos com ocupação relativamente densa em vídeo de $1988{ }^{227}$.

O espaço físico da escola técnica era praticamente o mesmo da escola prática. Os dois cursos oferecidos utilizavam as instalações técnicas pré-existentes, embora alguns edifícios tenham sido reformados ou atualizados. O caso mais aparente é o Edifício João Soares Veiga (figura 71). As áreas de produção também foram ampliadas, para abrigar as aulas e experimentos do VNP. A área de pastagem mais Figura 71: Edifício João Soares Veiga, atualmente.

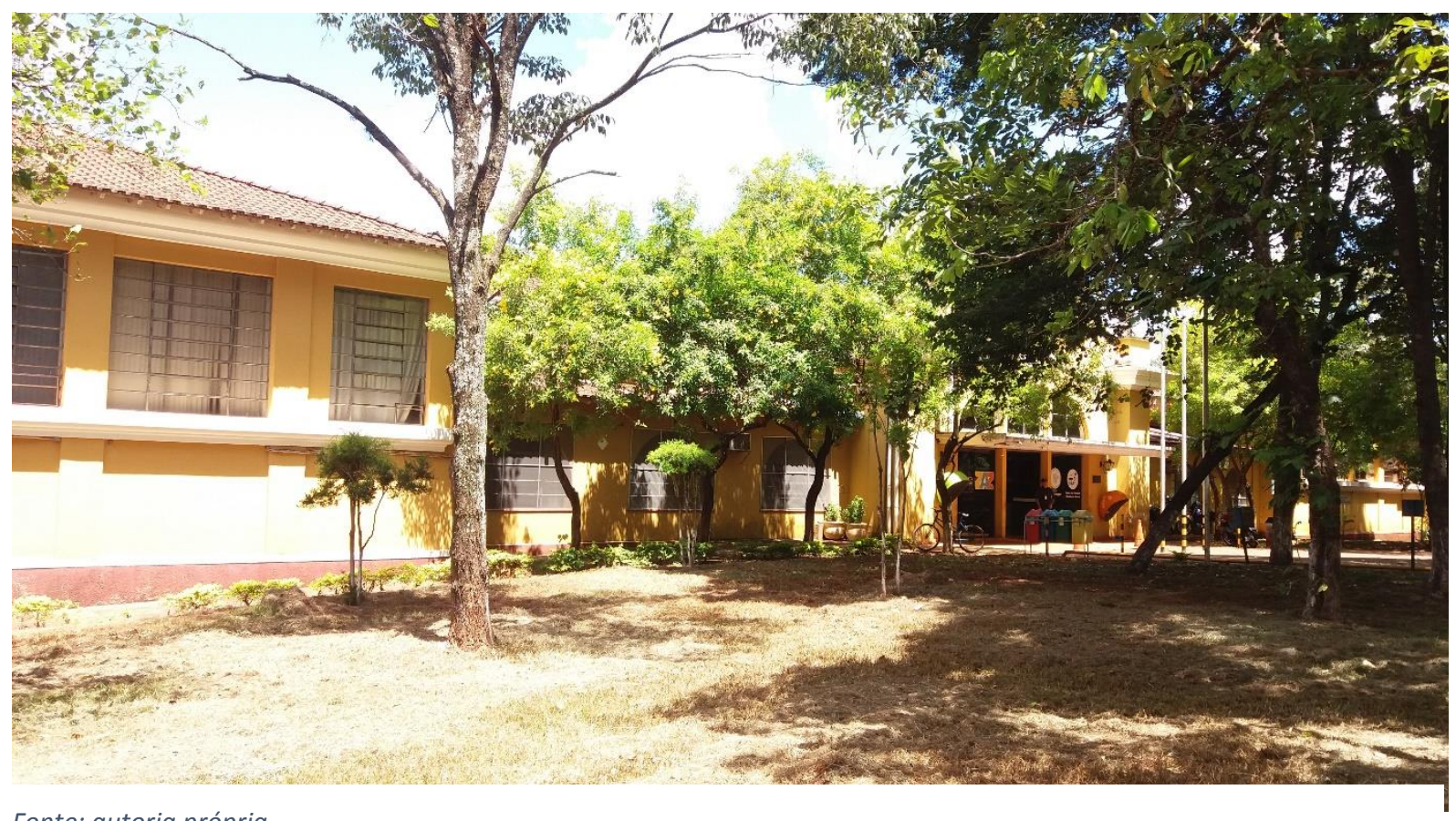

Fonte: autoria própria.

\footnotetext{
225 lbid, pg. 105.

226 Ibid., pgs. 91-101.

${ }^{227} \mathrm{https}: / / \mathrm{www}$.youtube.com/watch?v=5bHctUUbVr0
} 
antiga (conhecida como Santa Maria) era anterior à fundação da Escola Prática de Agricultura ${ }^{228}$. Mas áreas como a conhecida como "Projetão" foram iniciadas após a instalação do Departamento em Pirassununga. Também é do período o edifício de criação de coelhos (cunicultura), dois aviários experimentais e um confinamento de bovinos de corte 229 .

Essa intensidade da relação social e a proximidade física entre os territórios ocupados pela escola e universidade e a trama urbana permitem que façamos algumas inferências. A primeira é que se estabeleceu um vetor de crescimento da cidade, no sentido norte, rumo à portaria da escola e universidade. Com o crescimento da comunidade acadêmica, as colônias não eram mais suficientes para abrigar todos os funcionários e professores, que também preferiam morar em áreas mais próximas da cidade, a fim de se beneficiarem com as facilidades de comércio e outras vantagens. Esse vetor de crescimento depois foi assumido pelo poder público, que empreendeu vários loteamentos populares na região. Outra inferência possível é relativa ao espaço interno da instituição. A ocupação do território em determinadas áreas foi se reduzindo, em especial as colônias residenciais que estavam distantes Figura 72: Lagoa Francischini.

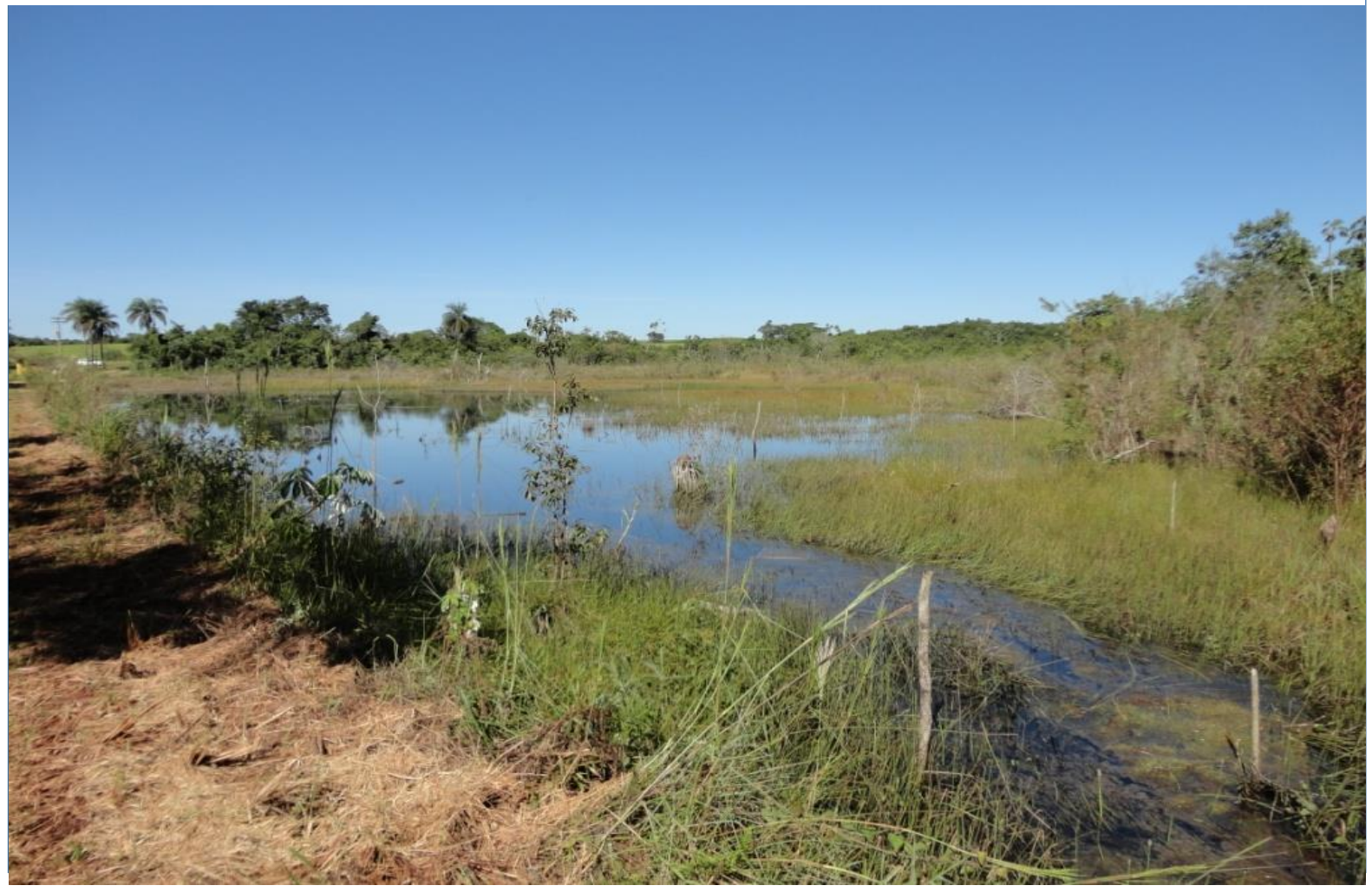

228 lbid., pg. 80.

${ }^{229}$ ALBUQUERQUE e GHION (2007), pg. 19. 
dos eixos principais de circulação (o eixo principal, a atual Estrada do Povo, e a estrada da Colônia dos Mestres). A vida urbana, a atratividade com os benefícios da cidade e mesmo das áreas mais movimentadas do território da escola / universidade, podem explicar o esvaziamento e a futura demolição dessas colônias, como a Francischini (figura 72), que antes da construção da Via Anhanguera era um local bastante movimentado 230 .

3.2.2 A influência das decisões administrativas no espaço físico.

Essas idas e vindas institucionais refletem a preponderância das decisões administrativas no gerenciamento do espaço físico, sobrepondo-se às decisões técnicas ou pedagógicas, às questões construtivas ou de interesse paisagístico ou urbanístico e mesmo o interesse público. Para alguns autores, é negligenciado o mecanismo que a construção (ou a distribuição) dos territórios universitários pode causar na estrutura institucional ${ }^{231}$. Mas ocorre principalmente o contrário: a instituição molda seus territórios conforme se rearranja essa estrutura.

Grande exemplo é a escola de São José do Rio Preto. O projeto original idealizado por Fernando Costa, que foi pessoalmente escolher o terreno, encontrava grande apoio da população e da política local. No entanto, pelo atraso na obra, sua inauguração não aconteceu durante o governo do idealizador. As posteriores e sucessivas trocas de governo motivaram discussões e especulações sobre a real finalidade do complexo em construção. Essas discussões e especulações, que circulavam desde o gabinete do governador às conversas informais nas praças da cidade, começaram em 1946, com a saída de Fernando Costa do governo, e seguiram até 1955. Em julho deste ano, começaria a funcionar como Instituto Penal Agrícola, mesmo com a opinião contrária da população e da política local. Opinião que, após consumado o fato, foi se alterando para o apoio à nova função. ${ }^{232}$

\footnotetext{
230 TELES e IOKOI (2005), pg. 80.

231 CUNHA, Luiz Antonio (2003), pg. 234.

232 MARQUES E CAMPOS (2011), pgs. 143-158.
} 
Com relação aos cuidados com a paisagem, observamos interferências inadequadas e prejudiciais. No caso estudado, não é visível apenas no violento impacto contra o projeto original, que foi a construção da Via Anhanguera sem qualquer respeito pelo traçado preexistente. Mas também se observam interferências na manutenção dos edifícios, alterados sem qualquer critério (o edifício João Soares Veiga é exemplar nesse período e o Parque de Exposições é exemplar em um período posterior).

Há, portanto, um conflito visível estabelecido entre a camada dirigente das instituições e o interesse social na preservação da paisagem. No lado das camadas dirigentes os interesses podem ser mais imediatistas, relacionados à solução de problemas cotidianos que acometem a gestão naquele momento. Como exemplo, podemos resgatar um caso recente, o episódio da crise de abastecimento de água que ocorreu em 2015. Nessa ocasião o Estado de São Paulo sofreu com a seca e o desabastecimento, obrigando diversas esferas governamentais a tomar decisões de urgência, seja determinando cortes e "rodízios", seja construindo obras emergenciais. No caso estudado, a crise também se abateu, já que o abastecimento interno do Campus Fernando Costa é feito com os recursos hídricos internos. O sistema de reserva, tratamento e distribuição chegou ao limite, obrigando a Prefeitura do Campus a realizar obras emergenciais, que estão em conclusão neste momento (dezembro/2016) e impactam a paisagem ao redor do Prédio Central (figura 73). Um aspecto curioso e assustador desse episódio é que não foi a primeira vez que ocorrem obras emergenciais após crises de desabastecimento. A atual estação de tratamento de água, igualmente situada ao redor do Prédio Central, também é resultado desse processo, porém três décadas antes. E igualmente impacta a paisagem. A implantação dessas obras no local em que estão é tecnicamente justificada pela proximidade com o reservatório elevado pré-existente, porém um processo de planejamento de longo prazo poderia resultar em obras mais adequadas e melhor implantadas. A crítica recai, portanto, no sistema de gestão e na estrutura de poder institucional, que não prezam pelo planejamento de longo prazo, exigindo do dirigente no momento da crise a iniciativa e a criatividade para resolvê-la. 
Figura 73: As estações de tratamento de água (acima a mais recente).

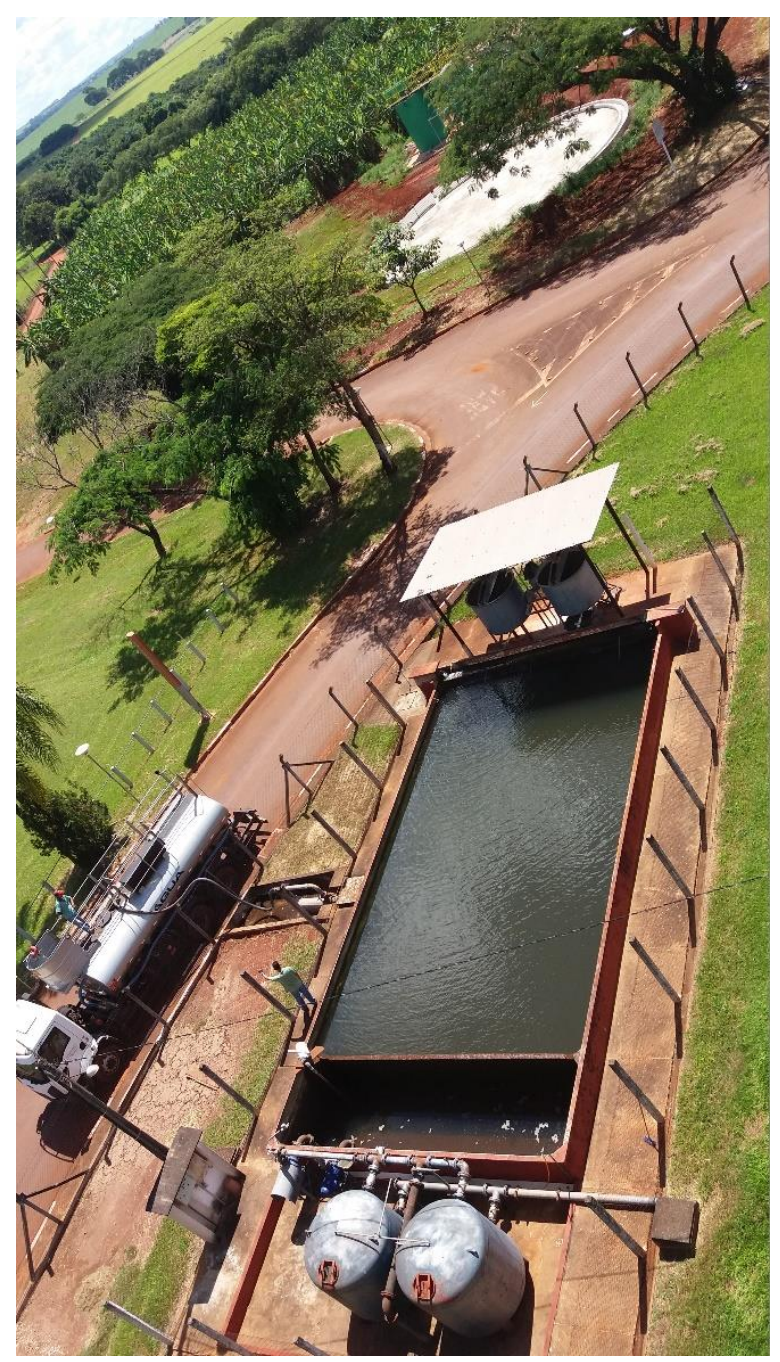

Fonte: autoria própria.
Mas essas decisões podem também ser políticas, vinculados a um grupo de poder do qual o dirigente faz parte, por sua vez ligados a determinada ideologia. Abrindo um parêntesis que depois será retomado, no capítulo 4 , convém rapidamente entender a Universidade no período pós-guerra, em algumas de suas questões mais amplas. Autores recentes e distintos como Souza Santos, Jaspers e Derrida explicam a Universidade como a casa do saber, comprometida com a verdade $\mathrm{e}$ desinteressada de outras finalidades, pelo menos em tese ${ }^{233}$. Essa Universidade, porém, serve a outros mestres. Sua condição atual é de submissão ao mercado capitalista ou, pelo menos, está sob pressão para que se submeta. Seu papel principal para a sociedade contemporânea seria a formação do "indivíduo-empresa" 234. Daí surgem as três crises que Boaventura de Souza Santos $(1997,2004)$ pontua em dois textos: a crise institucional, referente ao problema do financiamento público da Universidade; a crise de legitimidade, referente a não universalização do ensino superior; e a crise de contradição, entre a autonomia da Universidade e as pressões para sua eficácia. ${ }^{235}$

Essa universidade ideologizada, prestadora de serviços, vivenciando as crises citadas por Boaventura de Souza Santos, procura dirigentes e líderes que se adequem

233 BISCALCHIN (2008), pg.33.

${ }^{234}$ LAVAL e DARDOT (2013) explicam a como se dá o surgimento desse indivíduo-empresa, como é o "governo" desse sujeito e como a subjetividade dessa construção o estimula, por exemplo, para essa formação profissional qualificada e para a repetição contínua desses processos alienantes, o afastando, consequentemente, da emancipação.

235 SANTOS (1997) "Da Ideia de Universidade à Universidade de Ideias" e SANTOS (2004), "A Universidade do Século XXI: Para uma Reforma Democrática e Emancipatória da Universidade". 
a essa realidade: eficazes na busca por financiamento, com ótimo trânsito nas empresas que precisam de pesquisas e mão de obra altamente qualificada; eficazes na aplicação desse financiamento, seja criando vagas para ampliação da oferta, seja direcionando essas vagas para as formações ligadas às necessidades do mercado; e eficazes na gestão do dinheiro, melhorando índices e apresentado uma performance administrativa equiparável à das empresas privadas.

As decisões sobre o espaço físico, sob essa ideologia, são absolutamente funcionais. O objetivo do espaço físico é proporcionar essa funcionalidade e eficácia e, portanto, deve estar sempre atualizado. Estruturas obsoletas devem ser rapidamente substituídas e a demanda por espaço - esse espaço atualizado - é contínua. A relação dessa velocidade de decisão com o planejamento físico é interessante: Gaines cita casos que o planejamento foi posto de lado e o resultado foi positivo, como Harvard ${ }^{236}$. O Campus Vale da Universidade Federal do Rio Grande do Sul (UFRGS) é um caso intermediário: houve um replanejamento no qual se previu a ocupação das áreas entremeadas aos edifícios originais do primeiro planejamento, que era totalmente modular. Mas a ideia de transferir todas as unidades para 0 campus (situado na divisa com outro município), foi abandonada, para que as unidades mais antigas e importantes permanecessem no centro da cidade. Os casos de insucesso são mais comuns: o campus Maria Cândida da antiga Universidade Bandeirante de São Paulo (UNIBAN), atualmente Universidade Anhanguera (UNIAN), era obra de Rino Levi (originalmente uma indústria química), completamente descaracterizada pela construção de blocos pré-moldados de concreto, que avançavam conforme o número de matrículas da instituição aumentavam, além da construção de um anexo, para abrigar salas do curso de Direito, copiando em escala e proporcionalidade equivocadas um templo grego, com a inscrição "FORVM" no entablamento (figura 74).

236 GAINES (1991), pg. 10. 
Figura 74: o antigo Campus Maria Cândida da Uniban, atual Campus Vila Guilherme da Unianhanguera. $O$ prédio à esquerda é projeto de Rino Levi. O prédio à direita é modular e sofreu a intervenção citada.

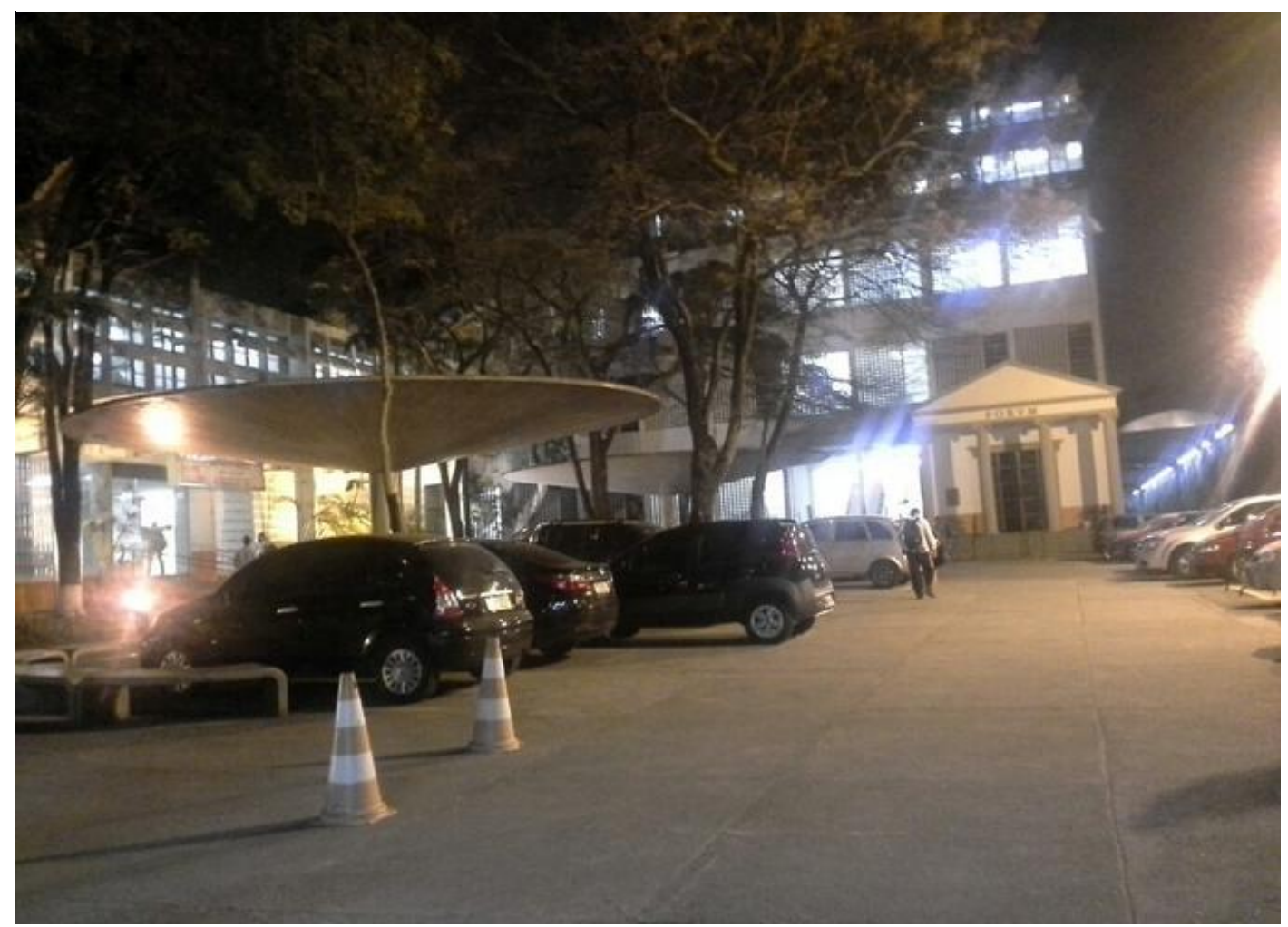

Fonte: André Martinez

O território cedido à USP em Pirassununga foi ocupado por duas instituições de visões distintas, ainda que submissas à essa ideologia. O IZIP/CIZIP formavam técnicos porém tinha um forte componente humanista ${ }^{237}$. Já a FMV/FMVZ sempre teve foco na formação profissional e na pesquisa acadêmica, representada em Pirassununga por departamentos que possuíam (e possuem) valores e missões operacionais, funcionais para a reprodução do capital.

Esses interesses, no caso estudado, não estiveram concatenados com a manutenção da paisagem, que foi degradada (como visto anteriormente). A atualização dos edifícios e das infraestruturas, que causaram essa degradação, estiveram (e estão) a serviço da Universidade funcional, operacional, ideologizada; e somente por isso foram realizadas.

Outro ponto relevante na percepção da influência das decisões institucionais sobre o espaço é a constatação da existência e da prevalência da burocracia na gestão universitária. As decisões sobre o espaço físico passam por trâmites 
impessoais, repletos de formalidades, esvaziando o aspecto democrático da gestão do espaço. Lembramos Rogério César Cerqueira Leite, que afirma a incompatibilidade entre atividade intelectual e burocracia. Segundo este autor:

"Em uma Universidade, quando os postos de decisão são assumidos por burocratas, os pesquisadores são paulatinamente sufocados e, consequentemente, ou se acomodam com as restrições à pesquisa, ou são expelidos. Somente aqueles que vivenciaram a pesquisa são capazes de compreender as necessidades do pesquisador. O burocrata substitui justiça por legalidade formal e competência por submissão e hierarquias. E não pode ser de outra maneira, pois o universo moral do burocrata é composto de hierarquia e de regras formais." 238

Destrinchando um pouco mais o impacto na paisagem das decisões institucionais de âmbito universitário, podemos observar outros exemplos, mais próximos de nosso objeto. Como vimos há pouco, houve, na segunda metade dos anos 1990, uma decisão em ampliar o número de vagas e cursos na USP. Obviamente, essa decisão seria acompanhada da ampliação do espaço físico. Por "motivos políticos" e decisões de caráter institucional, a ampliação no interior de São Paulo se concentrou em São Carlos (principalmente nos cursos ligados à tecnologia) e em Ribeirão Preto (principalmente nos cursos ligados à saúde, mas também em ciências sociais aplicadas). Pirassununga não estava no foco. Mesmo assim as pressões para ampliação foram parcialmente atendidas. A FZEA, que possuía apenas o curso de Zootecnia no momento de sua criação (1992), abriu o curso de Engenharia de Alimentos, previsto desde aquela data, em 2001. E apenas em 2009 abriria dois novos cursos (Medicina Veterinária e Engenharia de Biossistemas) e o programa de pós-graduação em Engenharia de Alimentos. Desde então, ainda abriu três novos programas de pós-graduação.

Essas decisões institucionais, sejam políticas, técnicas, ou objeto de pressão social, deveriam ser parte de um planejamento institucional que envolvesse vários componentes: o aspecto social, o aspecto financeiro e o aspecto físico e paisagístico. Na história da USP percebemos que vários surtos de desenvolvimento, após decisões institucionais, foram desacompanhados desse necessário planejamento.

No caso específico estudado, não havia qualquer planejamento para os aspectos físicos e paisagísticos até a conclusão de um Plano Diretor, cujo nome é relativamente inadequado, já que é apenas um exercício de desenho urbano com a 
demarcação de algumas arquiteturas, incluindo estudos preliminares, pouco mais avançados que planos de massas ${ }^{239}$. Esse Plano Diretor foi discutido e desenhado entre os anos de 2007 e 2008 e entregue em janeiro de 2009 para a unidade acadêmica interessada (FZEA), e única unidade contemplada no plano. Um equívoco de organização é que nesse momento já existiam contratos com escritórios de arquitetura para a confecção de projetos executivos de edifícios. Edifícios que não faziam parte deste Plano Diretor. Além disso, o Plano Diretor abordava uma área de apenas 13,7 hectares de um total de 2.240 hectares. Essas condições demonstram que o Plano Diretor não era "universitário", portanto não tinha uma visão totalizante do espaço e da instituição. E formalmente era apenas um instrumento de espacialização de obras para a demanda reprimida e imediata de uma unidade acadêmica, portanto uma estratégia de planejamento apenas parcial e sem abrangência de outras temáticas (financeira, administrativa, pedagógica, etc).

Os casos mais radicais de interferência na paisagem, no entanto, são exógenos. Não apenas decisões internas institucionais, que por força de imprevistos ou conjunturas podem causar impactos negativos na paisagem, mas decisões de órgãos e instâncias externas. A construção (e, como veremos, a duplicação) da Rodovia Anhanguera foram obras de grande vulto, de relevância nacional, e que por esses motivos aconteceriam de qualquer maneira, passando ou não pelo território da antiga Escola Prática de Agricultura. Mas o que aqui destacamos é a forma como o projeto aconteceu: rompendo a estrutura existente de maneira radical.

\subsection{A chegada da USP em Pirassununga.}

Como vimos, a USP se estabelece em Pirassununga inicialmente como escola técnica, por meio do IZIP e com a implantação do Departamento de Produção Animal da FMV (hoje conhecido pela sigla VNP), ambos em 1957. Os alunos do curso de Medicina Veterinária frequentavam algumas aulas em Pirassununga, normalmente saindo de São Paulo em uma sexta-feira e retornando no sábado. Em 1969 passam a ficar semanas completas, instalados nas alas residenciais e em algumas casas das

\footnotetext{
239 Ver ANEXO 2.
} 
colônias adaptadas para recebê-los. Em 1970 a sede do Departamento é transferida para Pirassununga ${ }^{240}$.

Em meados dos anos 1970 o Conselho da FMV decide instalar um curso superior de zootecnia totalmente abrigado na chamada "fazenda", a fim de melhor ocupar o espaço, enobrecendo-o aos olhos da instituição e da sociedade pirassununguense. Quando há a aprovação da instalação do curso, em 05/04/1974, também se motivou a alteração do nome da unidade, que passou a ser denominada Faculdade de Medicina Veterinária e Zootecnia (FMVZ), nome que persiste até hoje, mesmo com a transferência da responsabilidade pelo curso de zootecnia para a futura Faculdade de Zootecnia e Engenharia de Alimentos (FZEA). Nos cinco primeiros anos em que foi oferecido, o curso de Zootecnia teve aulas básicas oferecidas em São Paulo, mas depois foi integralmente oferecido em Pirassununga ${ }^{241}$.

É nesse período, entre o final dos anos 1960 e o final dos anos 1970, a USP efetivamente se instala em Pirassununga. O curso de Medicina Veterinária ocupa o espaço de maneira perene e é inaugurado o curso de Zootecnia. A inauguração do curso não ensejou a construção de novos edifícios, já que as aulas práticas eram aplicadas nos mesmos locais que o curso técnico. O curso técnico já não recebia mais investimentos. A formação ampla, de fundo humanístico que o curso técnico oferecia

Figura 75: Uma casa ocupada como depósito (por esse motivo foi cercada).

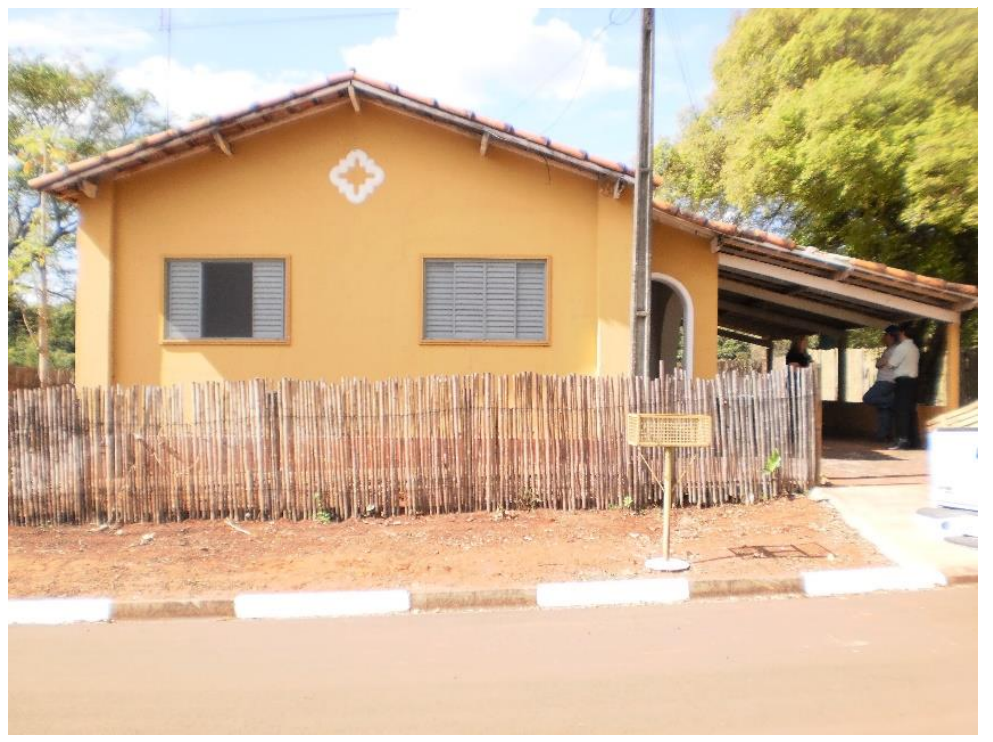

Fonte: autoria própria. pouco tinha a ver com a visão operacional desejável pela Universidade e pela própria sociedade, para um curso desse nível. A procura também diminuía - e nos anos 1980 a decisão da FMVZ foi fechar o curso.

Uma prática recorrente até os dias atuais também se inicia nesse período: o uso das antigas residências,

\footnotetext{
${ }^{240}$ ALBUQUERQUE e GHION (2007), pgs. 16-18.

241 Id., pg. 17.
} 
organizadas em "colônias", para outros fins, como laboratórios, escritórios administrativos de departamentos, núcleos e outros usos similares (figura 75).

O crescimento das atividades do Departamento de Produção Animal obrigou a FMVZ a dividi-lo em dois departamentos: Produção Animal (então abreviado VPA) e Criação de Ruminantes e Alimentação Animal (VCA), no final de 1984. A visibilidade conquistada pelo trabalho destes departamentos, multiprofissionais, gerou certa "ansiedade". Em 1988 um grupo de trabalho da reitoria inicia os estudos para a criação de um "campus administrativo" em Pirassununga. Essa ação é classificada como um "movimento separatista" pelos professores da FMVZ, o que foi confirmado com a criação da Faculdade de Zootecnia e Engenharia de Alimentos (FZEA) em 1992242.

Mesmo abrigando um curso superior integralmente ofertado em Pirassununga e com a grande produção dos departamentos de Veterinária, as pressões para uso mais intensivo do espaço não arrefeceram por anos. Abranda-se apenas em 1989, com a inauguração da "Prefeitura do Campus Administrativo de Pirassununga", e em 1992, com a separação da FMVZ e a criação da Faculdade de Zootecnia e Engenharia de Alimentos (FZEA. Para os professores da FMVZ foi um movimento separatista, que causou prejuízos temporários para a unidade (e especialmente os departamentos sediados em Pirassununga, antes tão importantes). Esses possíveis prejuízos foram sanados com a fusão dos departamentos no atual VNP, em 1997 243. Mas, para a Universidade, as perspectivas de crescimento se abririam enormemente. Hoje a FZEA conta com quatro cursos de graduação e cinco programas de pós-graduação (e aprovados outros dois cursos de graduação).

3.3.1 O crescimento da USP em Pirassununga em comparação com os demais campi da Universidade

É importante reforçar que durante as décadas de 1960, 1970 e 1980 as pressões para ampliação do uso em Pirassununga e as novas atividades de nível superior pouco influenciaram no desenvolvimento físico do território uspiano em

\footnotetext{
242 lbid., pg. 22.

243 lbid., pg.23.
} 
Pirassununga. Em entrevista, a professora Ada Pellegrini Grinover, Pró-Reitora de Graduação entre 1997 e 2001, afirma que a expansão da USP nos subsequentes anos 1990 e 2000 poderia ter acontecido em Pirassununga, mas a decisão final foi a aquisição de uma segunda área em São Carlos, por motivos políticos ${ }^{244}$. A professora afirma que:

\footnotetext{
...trabalhei muito, com os diretores e os professores, para a ampliação do campus de Pirassununga, conseguida com muitas dificuldades. Mas o campus - uma enorme fazenda com edificações já prontas - ainda está sub-utilizado. Meu projeto era criar outros cursos em Pirassununga. Em vez disso, decidiu-se criar o segundo campus de São Carlos. Lá não tinha água, nem luz. Só a infraestrutura deve ter custado uma fábula. Mas, afinal, foi uma decisão política.
}

A história do campus São Carlos da USP tem início em 1948, com um Decreto que instala uma Escola de Engenharia na cidade, vinculada à USP. Nos quatro anos seguintes há o trabalho das comissões executivas, que conseguiram fazer iniciarem as aulas de dois cursos (Engenharia Civil e Mecânica) em abril de 1953. O ensino considerado inovador e a dinâmica econômica da cidade, que desde os anos 1940 já possuía muitas fábricas, promoveu o sucesso da escola. Suas instalações iniciais foram em prédios emprestados, mas desde 1952 a Universidade já possuía uma área, doada pela Prefeitura do Município. Em 1954 o plano de ocupação do território e o projeto modelo dos edifícios foi apresentado, pelo arquiteto Hélio Duarte - de vasta produção de planos edifícios universitários - e Ernest Mange. O edifício E-1, o primeiro a ser edificado, ainda de acordo com o plano de Duarte e Mange, foi inaugurado em 1957. Entre 1958 e 1961 alguns outros edifícios foram construídos e um novo plano foi realizado. Desde então, os pouco mais de $300.000 \mathrm{~m} 2$ de terreno foram ocupados progressivamente, conforme os cursos se consolidavam - e conforme alguns deles geravam novas unidades ${ }^{245}$. Ao mesmo tempo, a cidade de São Carlos progrediu rapidamente e foi contemplada com a primeira universidade federal no Estado: a Universidade Federal de São Carlos (UFSCar), fundada em 1 de dezembro de 1968.

Na virada dos anos 1980 para 1990 a USP em São Carlos já estava completamente consolidada. E também congestionada. Entre professores, funcionários não-docentes e alunos, a população circulante era superior a 4.800

\footnotetext{
${ }^{244}$ MOTOYAMA (2006), pg. 440.

${ }^{245}$ ALTAFIM (2004).
} 
pessoas. A área construída superava $62.500 \mathrm{~m} 2{ }^{246}$. Dez anos depois, já eram 6.000 pessoas e a área construída superava $97.600 \mathrm{~m} 2{ }^{247}$.

O sucesso da USP em São Carlos, mais o desenvolvimento e a dinâmica da cidade, o esforço conjunto entre as instituições de ensino superior e o congestionamento do território ocupado pela USP ensejaram a discussão sobre a ampliação da USP na cidade por meio de uma nova área. Em 2001 um grupo de trabalho desenvolveu estudos para adquirir esta área nova e a escolha foi por um terreno na própria cidade de São Carlos, com 73 hectares (depois ampliados para 102 hectares). Inaugurada em 2005, atualmente essa área contém edifícios das áreas de Aeronáutica, Computação, Ambiental e Materiais e Manufatura, além de instalações comuns às unidades e a construção de um Centro de Convenções.

Em nosso entendimento, o fato da USP realizar investimentos em São Carlos não exclui (e não excluía) a possibilidade de realizar investimentos em Pirassununga, mesmo que a distância entre os locais seja relativamente pequena $(75 \mathrm{~km})$. Afinal, os territórios apresentam diferentes características físicas e sociais, as cidades possuem diferentes perfis socioeconômicos e as unidades acadêmicas preexistentes já possuem certa especialização. Além disso, a Universidade viveu, nos mais de oitenta anos de história, fases de grande investimento e desenvolvimento, distribuídos em mais de uma localidade. Portanto, o desenvolvimento mais modesto em Pirassununga não teria como explicação apenas uma decisão política.

Em Ribeirão Preto, outro território da USP que teve origem nas antigas Escolas Práticas de Agricultura, a universidade ocupa os espaços e se desenvolve de maneira mais intensa e mais diversificada. A Faculdade de Medicina de Ribeirão Preto (FMRP), criada por um decreto em 1948, ocupa alguns edifícios da cidade durante os primeiros meses de existência e depois se muda para o prédio central da antiga Escola Prática de Agricultura Getúlio Vargas, desde 1952. A antiga escola, que cessou suas inscrições no ano anterior, funcionou por menos de dez anos. A nova Faculdade de Medicina teve como primeiro diretor o Prof. Zeferino Vaz, personalidade empreendedora e que futuramente teria papel determinante também no

\footnotetext{
246 USP (1992). Anuário Estatístico 1991.

247 USP (2002). Anuário Estatístico 2001.
} 
desenvolvimento de outra grande universidade paulista, a Universidade Estadual de Campinas (Unicamp).

A implantação da Faculdade de Medicina teve apoio financeiro da Fundação Rockfeller, que também recomendou (ou exigiu) determinado partido pedagógico, seguindo o "modelo americano". O aporte de verbas, principal fonte de financiamento para a implantação da faculdade, era argumento suficiente para a adoção desse partido. Vinte e seis anos depois o Hospital das Clínicas foi inaugurado em área próxima ao prédio central ${ }^{248}$. A Faculdade de Medicina também passou a oferecer outros cursos, como Ciências Biomédicas (desde os anos 60), Terapia Ocupacional, Fisioterapia e Fonoaudiologia. Quase concomitantemente com a Faculdade de Medicina, foi fundada também a Escola de Enfermagem de Ribeirão Preto (EERP), em 1953. Esta unidade continua responsável pelo curso de Enfermagem e por quatro programas de pós-graduação ${ }^{249}$.

Já existia, em Ribeirão Preto, outra instituição de ensino superior na área da saúde. Desde 1924 eram oferecidos cursos de Farmácia e Odontologia na Escola de Pharmacia e Odontologia de Ribeirão Preto (EPORP), inicialmente gerida por uma associação privada. Em 1958 o Governo do Estado encampa a escola. Em 1974 é transferida para a USP, institucionalmente e fisicamente. Em 1983 é desmembrada, dando origem às atuais Faculdade de Odontologia de Ribeirão Preto (FORP) e Faculdade de Ciências Farmacêuticas de Ribeirão Preto (FCFRP), cada qual responsável pelo respectivo curso de graduação e programas de pós-graduação ${ }^{250}$.

Outros cursos foram inaugurados ao longo dos anos, aproveitando as instalações voltadas ao ensino de Medicina e Enfermagem. Foram autorizados por um decreto de 1959 o funcionamento dos cursos de Ciências Biológicas, Psicologia e Química. Foram efetivamente implantados em 1964 e deram origem, em 1966 à Faculdade de Filosofia, Ciências e Letras de Ribeirão Preto (FFCLRP), que apesar de funcionar no território uspiano, só foi incorporada à universidade também no ano de 1974, assim como a EPORP. Outros cursos foram criados no decorrer das décadas e

\footnotetext{
${ }^{248}$ RODRIGUES E ILIANO (S/D).

249 http://www.eerp.usp.br/corporate-a-eerp/. Acessado em 10/01/2017.

250 http://www.forp.usp.br/?page_id=455
} 
hoje esta unidade oferece onze cursos de graduação e oito programas de pósgraduação ${ }^{251}$.

Nos últimos anos, novas unidades foram criadas em Ribeirão Preto, conferindo à universidade um caráter multidisciplinar. A Faculdade de Economia e Administração de Ribeirão Preto (FEARP), fundada em 2002, tem origem em cursos da Faculdade de Economia e Administração (FEA) situada em São Paulo, inaugurados em 1992. Oferece atualmente três cursos de graduação e três programas de pós-graduação. A Faculdade de Direito de Ribeirão Preto (FDRP) foi fundada em 2007 e é responsável pelo curso de graduação e um recém-inaugurado programa de pós-graduação. A Escola de Educação Física e Esporte de Ribeirão Preto (EEFERP) foi inaugurada em 2009 e é igualmente responsável por um curso de graduação e um recém-inaugurado programa de pós-graduação.

A importância que o "Campus Ribeirão Preto" alcançou na USP pode ser medida com várias métricas. Politicamente, o campus já forneceu três reitores para a universidade. Dos quase 95 mil estudantes matriculados, 14 mil estão em Ribeirão Preto. Dos 83 anos de história da USP, em 61 deles a instituição esteve presente na cidade. $O$ ensino agrícola para o qual o território antes se dedicava, não chegou a uma década de funcionamento. A infraestrutura planejada e implantada para a escola de agricultura foi adaptada e, com as progressivas ocupações nas áreas livres, deu origem a um bucólico, porém movimentado, território universitário - que quase em nada lembra o ensino de práticas agropecuárias. Outro aspecto determinante é a relação do território universitário e a cidade. Ribeirão Preto é hoje uma metrópole com quase setecentos mil habitantes, com uma dinâmica urbana bastante complexa. $O$ território uspiano está inserido nessa trama, ora servindo como elemento indutor de crescimento da cidade, ora como bloqueio físico (não nos cabe aprofundar essa dinâmica no âmbito desse trabalho). Consideramos que cada território vivenciou diferentes dinâmicas ao longo do tempo, histórias que separaram um início comum, ainda que alguns elementos da paisagem claramente ainda se assemelhem. As poucas comparações possíveis relacionam-se com o projeto original e de como esse projeto original pode ser observado hoje: a semelhança está na relação dos edifícios com o traçado viário, a relação do traçado viário com os jardins e massas arbóreas e

251 http://www.ffclrp.usp.br/affclrp/historico.php. Acessado em 10/01/2017. 
a arquitetura dos edifícios originais. As diferenças estão na densidade, na relação com a cidade, na identidade do lugar, na população circulante, etc.

Há a Faculdade de Odontologia de Bauru (FOB), que foi criada em 1948 mas instalada apenas em 1962, ainda em prédios emprestados. Nesta década foram inauguradas as instalações próprias da unidade, depois complementadas por um Centro de Pesquisa que veio a se tornar o Hospital de Reabilitação de Anomalias Craniofaciais (HRAC). O "Campus Administrativo" (futura Prefeitura do Campus) foi fundado em 1985. Além do curso de Odontologia, a unidade também oferece o curso de fonoaudiologia e oito programas de pós-graduação.

A reduzida área da USP em Bauru, confinada em dois grandes quarteirões urbanos, é a explicação principal para o crescimento histórico relativo pequeno da instituição na cidade. Também explica a especialização funcional, em atividade tipicamente urbana, porém pouco compatível com outras finalidades, com exceção de cursos na área de biológicas, que no interior do Estado estão concentrados em Ribeirão Preto. É curioso notar que a cidade cresceu velozmente em períodos mais recentes (em 1970 Bauru possuía 130 mil habitantes, hoje possui quase 370.000 ), o que poderia ensejar investimentos no surto de crescimento da USP na última década, mas isso não ocorreu. Há poucas comparações possíveis com o desenvolvimento do território uspiano em Pirassununga. Afinal, são bem distintas: a situação deste território na cidade, as dimensões do território, os usos especializados, a identidade bastante demarcada, entre outros aspectos.

Com relação à Piracicaba já realizamos um estudo comparado (capítulo 2.4.1), com maior foco nos projetos originais. Com relação ao crescimento da universidade em ambas as localidades, para efeito de comparação, verificamos que há aproximadamente 3.000 alunos em Piracicaba para 1.700 alunos em Pirassununga (mais 400 de Medicina Veterinária que funcionam parcialmente em Pirassununga). Em Piracicaba há sete cursos de graduação, todos direta ou indiretamente ligados com o ambiente rural. Em Pirassununga há cinco cursos de graduação, igualmente ligados com esse ambiente. A total de área construída de Piracicaba é de 263.000,00 $\mathrm{m} 2$, enquanto a área construída de Pirassununga é mais modesta, totalizando $130.000,00 \mathrm{~m} 2$.

O maior desenvolvimento do território uspiano em Piracicaba em comparação com Pirassununga pode ser explicado por alguns fatores, como o tempo de existência 
maior, a oferta de educação de nível superior há mais tempo, a maior dinâmica urbana em Piracicaba e o peso político maior da ESALQ, que inclusive já cedeu à USP dois reitores. Porém ambos os territórios continuam com características similares: preservam o histórico enfoque (ou especialidade) na realidade agropecuária; compõem uma paisagem tipicamente rural; guardam grande importância para a dinâmica da cidade que os sedia, compondo inclusive um fator de identidade para as mesmas; possuem a maior parte de edifícios com linguagem arquitetônica comum; preservam (ou tentam preservar) jardins e parques do projeto original. Outras características desse viés territorial, que aparecem em maior ou menor grau em cada um dos casos, são: maioria de cursos tecnológicos na área de produção agropecuária; situação em cidade de interior, limítrofe ou próximo - porém não integrante - da trama urbana; pouca diversificação em outras áreas de conhecimento; existência de uma dinâmica política interna; implantação e arquitetura que expressam o desejo de representar uma história e uma realidade rural; etc.

Finalmente, tendo essas comparações como base, consideramos que o fato de Pirassununga ser um campus interiorano e de viés rural influenciou seu desenvolvimento no tempo. Por um lado, preservando a arquitetura e partes da paisagem (com a exceção das transformações - as grandes obras externas à política universitária). Por outro lado, perdendo algumas das oportunidades típicas da vida universitária, na troca de diferentes saberes e convivência entre os distintos.

3.3.2 A segunda transformação na paisagem: duplicação da Via Anhanguera.

Ainda nos anos 1970 acontece segunda grande transformação na paisagem: a duplicação da Via Anhanguera. A importante via de acesso entre São Paulo e o interior do país tem origem no antigo Caminho do Anhanguera, que desbravou as matas então ocupadas pelos índios e induziu a ocupação portuguesa rumo ao que hoje denominamos Região Centro-Oeste. A pavimentação começou no governo estadual de Washington Luís, ainda nos anos 1920 e seguiu progressivamente, passando por Pirassununga na primeira metade dos anos 1950 e causando a primeira violência na paisagem, como apresentado anteriormente. A duplicação começa nos anos 1950, da capital paulista rumo Jundiaí, e progressivamente segue ao interior, passando por 
Pirassununga nos anos 1970 (e é concluída, na divisa com Minas Gerais, nos anos 1990) 252 .

Em algum momento cuja precisão não pode ser determinada, entre os anos 1958 e 1970, foi construído um portal, curiosamente em estilo moderno ou art-decó (figura 77). Esse edifício não possuía qualquer relação com a arquitetura neocolonial pré-existente. Era situado no cruzamento dos eixos da rodovia Anhanguera com o eixo principal do IZIP. Não foi possível localizarmos projetos ou fotos mais próximas deste prédio, mas as informações básicas são corroboradas em conversas informais com funcionários que vivam no antigo IZIP, naquele momento.

A obra de duplicação também teve grande impacto na paisagem. Em primeiro lugar, causou a demolição deste portal, que já era um elemento espúrio, pouco coerente com o projeto original da antiga Escola Prática de Agricultura. Além disso, ensejou a construção de um túnel sob a rodovia, com duas faixas de rolamento. Esse túnel tem uma abordagem em desnível, com uma rampa no acesso e outra na saída, o que causou o rompimento visual do eixo principal. A vista progressiva para a grande rotatória e, no ponto mais alto, o prédio central, ficou interrompida pelo túnel (figura 76). Para o funcionamento adequado da drenagem de águas pluviais foram

Figura 76: O cruzamento em desnível do eixo principal com a Rodovia Anhanguera.

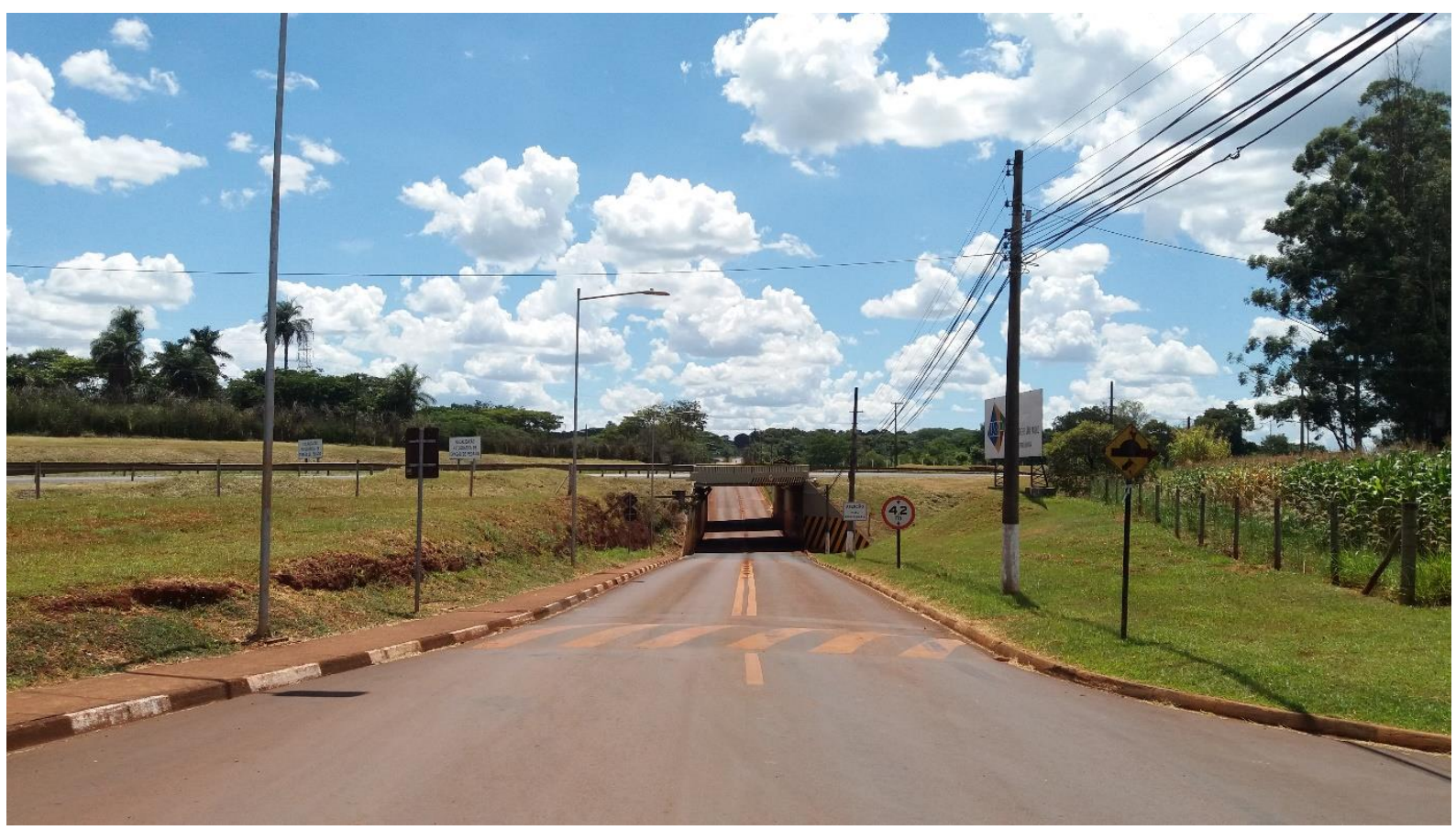

Fonte: autoria própria.

252 REIS (2014), pg. 91. 
executadas algumas obras, como a construção de um pequeno lago, algumas pequenas barragens e tubulações, para que o sistema funcione sem a necessidade de bombas elétricas ou dispositivos que exijam maior manutenção. A comunicação com a rodovia tornou-se apenas visual, já que não há um trevo ou conexão viária, mas apenas o cruzamento em desnível.

A ausência de dados mais precisos não permite uma análise mais apurada do impacto dessa intervenção, além do que pode ser observado ainda hoje ou discutido com pessoas que conheceram o território antes da intervenção. Mas é possível concluir que a obra foi executada sem qualquer preocupação com estruturas préexistentes, cujas adequações foram realizadas da maneira mais rápida e econômica, sem reflexão aprofundada sobre seus impactos na paisagem, no cotidiano e funcionamento do território.

Figura 77: o portal demolido.

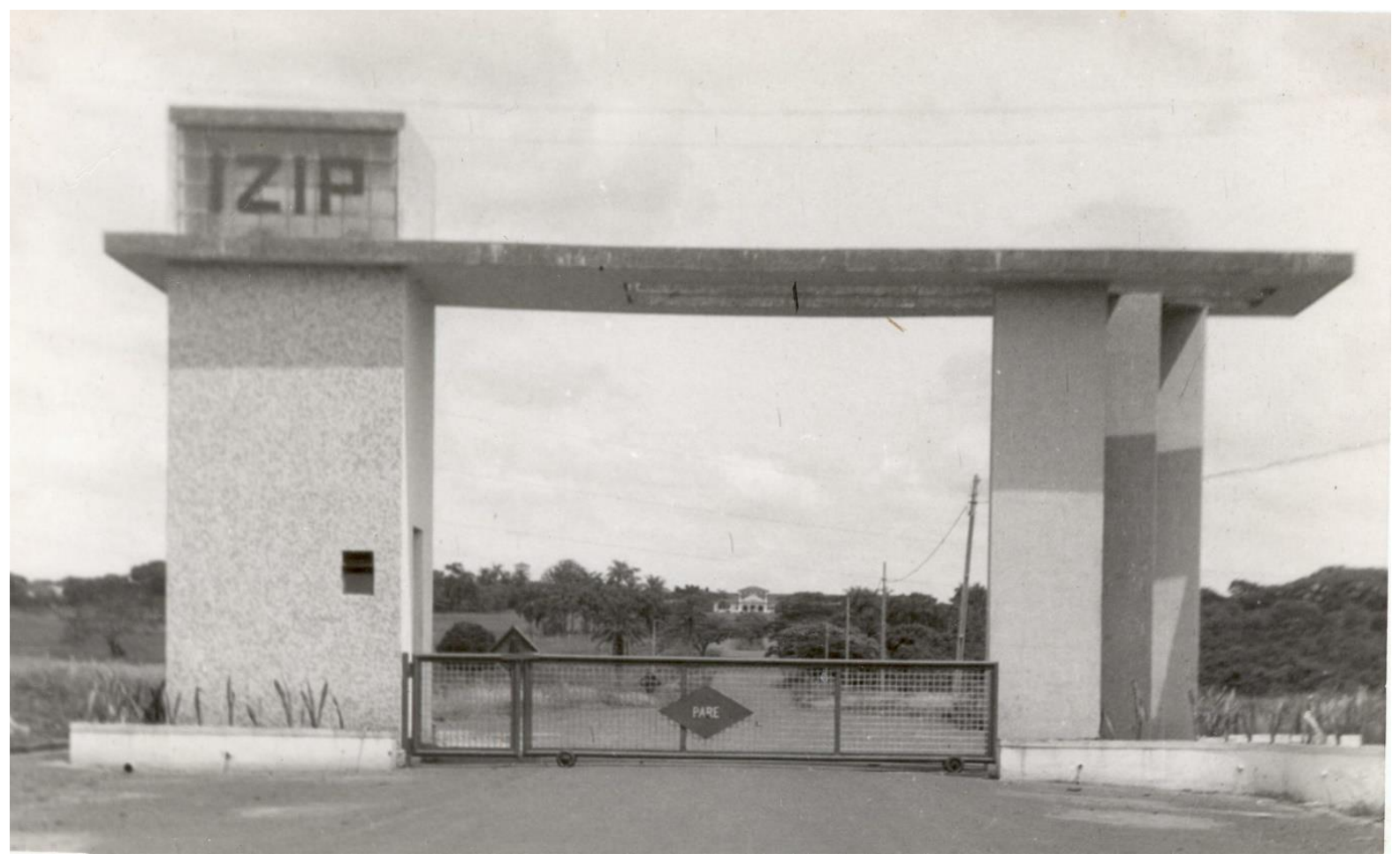

Fonte: Acervo FZEA. 


\subsection{O Campus Fernando Costa e a USP hoje}

A Universidade de São Paulo passou por uma fase de grande expansão nos últimos quinze anos, iniciado na reitoria da professora Suely Vilela e continuada na gestão do professor João Grandino Rodas. Segundo o Anuário Estatístico, no ano 2001, ainda na gestão do professor Adolpho Melfi, a USP oferecia nos seus 179 cursos de graduação o total de 7.354 vagas. Estavam matriculados 40.162 alunos na graduação. Na pós-graduação eram oferecidos 501 cursos, nos quais estavam matriculados 23.765 alunos. Haviam 4.755 docentes e 14.611 servidores não docentes ${ }^{253}$. Em 2014, no primeiro ano da gestão do professor Marco Antônio Zago, que sucedeu o professor João Grandino Rodas, a USP oferecia 11.057 vagas em 300 cursos de graduação. Estavam matriculados 59.081 alunos na graduação. Na pósgraduação eram oferecidos 676 cursos em 222 programas, com 30.039 alunos. Haviam 6.090 docentes e 17.199 servidores não docentes ${ }^{254}$. Percebemos, portanto, grande expansão: $50 \%$ de aumento de vagas e $67 \%$ de acréscimo de cursos, com $45 \%$ alunos a mais na graduação. Na pós-graduação foram $35 \%$ de acréscimo de cursos, com $26 \%$ a mais de alunos matriculados. O corpo docente cresceu $28 \%$ e o número de servidores não docentes foi acrescido em $18 \%$.

Em Pirassununga também houve um surto importante de expansão. Em 1992 houve a fundação da FZEA, que preparou as bases administrativas para essa expansão, que deveria iniciar com a implantação do curso de Engenharia de Alimentos. Porém o curso foi instalado apenas em 2001. A partir desse ano, a progressão foi contínua. Em 2001, haviam 41 docentes e 56 servidores não docentes, para os dois cursos de graduação e um programa de pós-graduação, com níveis de mestrado e doutorado. Na graduação estavam matriculados 207 alunos e na pósgraduação 101 alunos. O total de área construída ocupado pela unidade era de 18.674 m2, a maioria herdada de instalações pré-existentes da antiga Escola Prática de Agricultura. Outros $33.738 \mathrm{~m} 2$ eram ocupados pela Prefeitura do Campus e aproximadamente $20.000 \mathrm{~m} 2$ pela FMVZ (os dados são imprecisos pois o dado não

\footnotetext{
253 USP (2002).

254 USP (2015). É o Anuário Estatístico mais atualizado disponível na página da Universidade na internet.
} 
constava do anuário) ${ }^{255}$. Em 2014 já eram 111 docentes e 140 servidores não docentes, para quatro cursos de graduação e cinco programas de pós-graduação, sendo quatro com nível de doutorado. Na graduação estavam matriculados 1.452 alunos e na pós-graduação 395 alunos. O total de área construída cadastrada era $23.572 \mathrm{~m} 2$, mais $39.878 \mathrm{~m} 2$ para a Prefeitura do Campus (o total da FMVZ provavelmente com poucas alterações) ${ }^{256}$. O crescimento é notável: o corpo docente cresceu $270 \%$ e o número de servidores não docentes cresceu $250 \%$. O número de cursos de graduação dobrou e de pós-graduação passou de um para cinco. A quantidade de alunos matriculados na graduação é sete vezes maior em 2014 do que em 2001 e na pós-graduação quatro vezes maior, no mesmo período.

O curso de Engenharia de Alimentos, inaugurado em 2001, passou a oferecer vagas também no período noturno, a partir de 2004. Os cursos de Medicina Veterinária e Engenharia de Biossistemas foram oferecidos a partir de 2009. Na pós graduação, o curso de Zootecnia, inaugurado em 1994, foi o primeiro no Campus. Em 2009 passou a ser oferecido o curso de pós-graduação em Engenharia de Alimentos e entre 2012 e 2013 os cursos de Engenharia e Ciência de Materiais, Biociência Animal e Gestão e Inovação na Indústria Animal (este apenas no nível de Mestrado Profissional) ${ }^{257}$. Os cursos em todos os níveis guardam relações com o ambiente rural e o circuito produtivo da agropecuária, direta ou indiretamente.

Essa expansão institucional também teve reflexos no espaço físico. Entre 2001 e 2014 a área construída foi acrescida de apenas $21 \%$, conforme os dados dos Anuários Estatísticos. Porém dados mais recentes demonstram com mais precisão o aumento de área construída. Em consulta ao cadastro da SEF, atualizado em 2016, a FZEA possui hoje 29.032,00 m2. A FMVZ possui o total de 20.978,00 m2 e a Prefeitura do Campus possui $42.361,00 \mathrm{~m} 2$. No total, o território da USP em Pirassununga possui $93.008,65 \mathrm{~m} 2$. O cadastro do ano 2010 possuía o total de $79.130,00 \mathrm{~m} 2$, o que indica um acréscimo de $17,5 \%$ na área construída, em seis anos, o maior índice desde a fundação da Escola Prática de Agricultura por Fernando Costa. Hoje, a área

\footnotetext{
255 USP (2002).

256 USP (2015).

${ }^{257}$ www.fzea.usp.br, acessado em 07/01/2017.
} 
construída em Pirassununga responde por 2,9\% do total da área construída de toda a USP 258 .

A expansão recente da USP em Pirassununga se concentrou em alguns recortes específicos do território. O principal recorte é o entorno do antigo Parque de Exposições, seguindo o preconizado no Plano Diretor da FZEA. Outro local que expandiu sua área construída é a região da "Estrada do Povo". E o terceiro local que também teve significativos acréscimos em área construída é o entorno do Prédio Central.

Ao redor do antigo Parque de Exposições foram realizadas as primeiras obras após a criação da FZEA (figura 78). Ainda nos anos 1990 algumas edificações préexistentes, como estábulos, salas de guarda de rações e outros usos auxiliares ao Parque foram adaptados para abrigar salas de aula, laboratórios, a biblioteca e algumas áreas administrativas. Apenas a biblioteca ainda não permanece no local (entre 2009 e 2011 foi construído um edifício para abrigá-la, também no entorno do antigo Parque). O primeiro edifício construído exclusivamente para a nova unidade, nesta região, foi a sede do Departamento de Engenharia de Alimentos, cuja primeira fase foi construída entre 2001 e 2002 e a segunda fase entre 2005 e 2006 . Também nessa região foram construídos os prédios do curso de Engenharia de Biossistemas (um bloco com salas de aula e um bloco de laboratórios, também administrativo), entre os anos de 2011 e 2014. Um pouco mais distante, entre o antigo Parque e o antigo Clube de Campo (atual Centro de Eventos), foram construídos a Unidade Didática Clínico Hospitalar (UDCH), que funciona como um hospital veterinário, e o edifício de laboratórios deste curso, um de cada lado do eixo principal. O único edifício que possui características arquitetônicas merecedoras de nota é o que abriga a biblioteca.

Em consulta à Superintendência do Espaço Físico (SEF), órgão da USP responsável pelo cadastro e planejamento de seu território (sucessor do Fundo de Construção da USP), verificamos que há projetos não executados para essa região. São eles: um terceiro edifício do curso de Engenharia de Biossistemas, dois blocos de um complexo de Biotecnologia Animal, um edifício administrativo e acadêmico para a pós-graduação, um conjunto de salas de aula, o segundo edifício do curso de Engenharia de Alimentos e um núcleo de tecnologias alternativas de construção rural.

258 USP (2015). 
Figura 78: Mapa indicando os prédios novos (em vermelho) e planejados (em verde) na área frontal do campus.

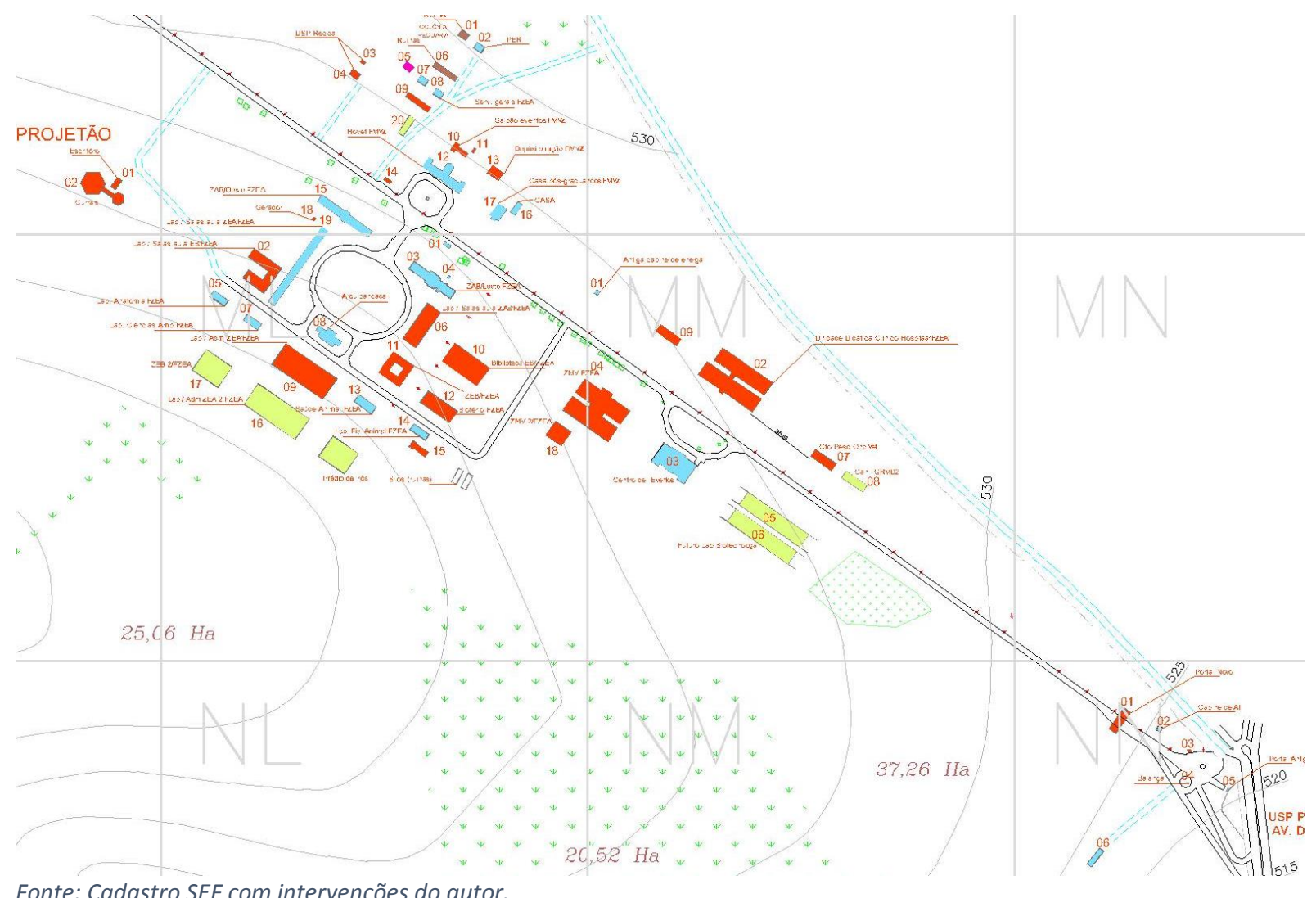

Essa região, portanto, concentra a maior parte da expansão recente da USP em Pirassununga. O resultado é a descaracterização do antigo arranjo espacial, ainda que dois elementos resistam e ainda demarquem o histórico: o edifício da arquibancada e a praça ovalada defronte sua fachada, no centro do complexo. Ainda que os usos tenham se tornados anacrônicos (não há exposições de animais no local há mais de quatro décadas), os dois elementos, complementares, são o registro Figura 80: Estado atual da arquibancada.

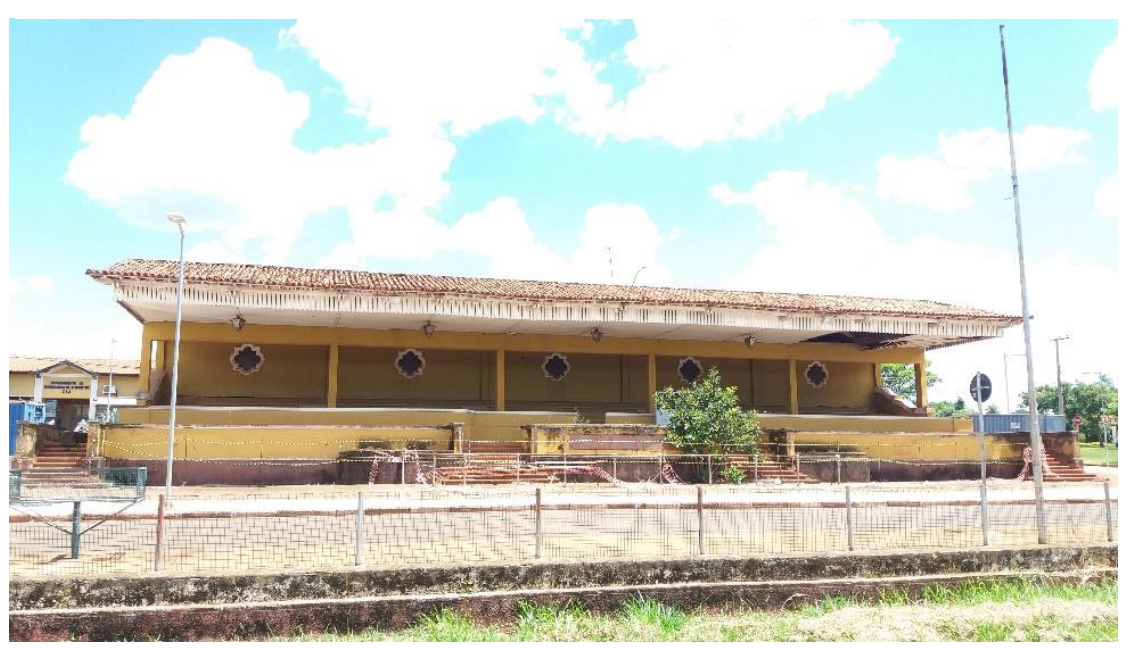
daquele período. $\mathrm{O}$ estado de conservação é precário, porém há gestões da SEF para que seja realizada a recuperação estrutural da arquibancada e para a manutenção da praça (figura 80). 
Figura 79: Mapa da área do prédio central indicando os prédios acrescentados (em vermelho) e planejados (em verde).

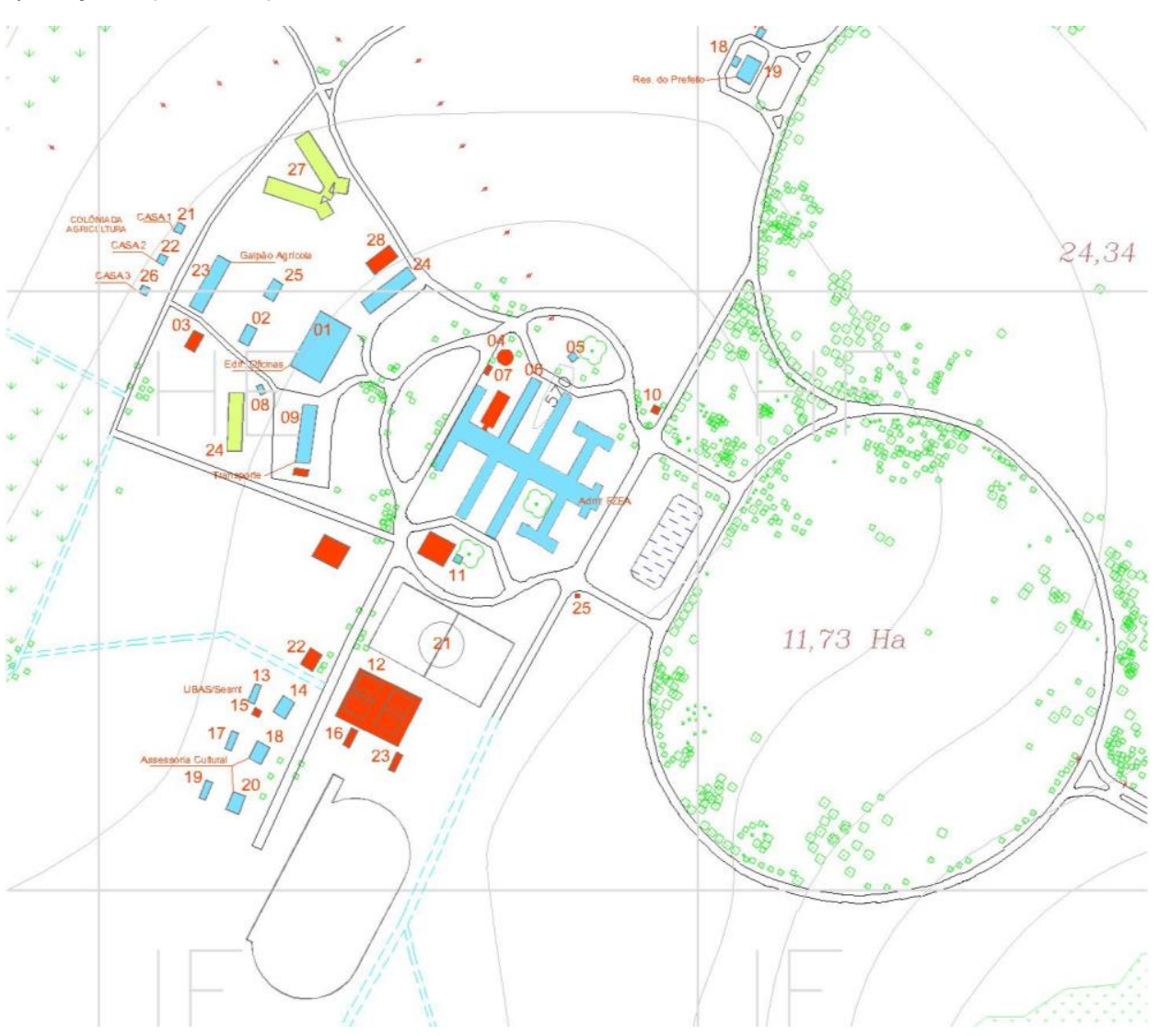

região do

Prédio Central alguns poucos edifícios foram construídos, a maioria de menor escala (figura 79). Atrás dos galpões operacionais do projeto original da Escola, foram edificados alguns novos galpões, em estrutura metálica, para fins diversos. O complexo é totalmente dedicado às atividades de manutenção e operação do território (oficinas mecânicas, serralherias, marcenarias, elétricas, hidráulicas, armazenamento, almoxarifado, etc). Na porção Figura 81: Área esportiva.

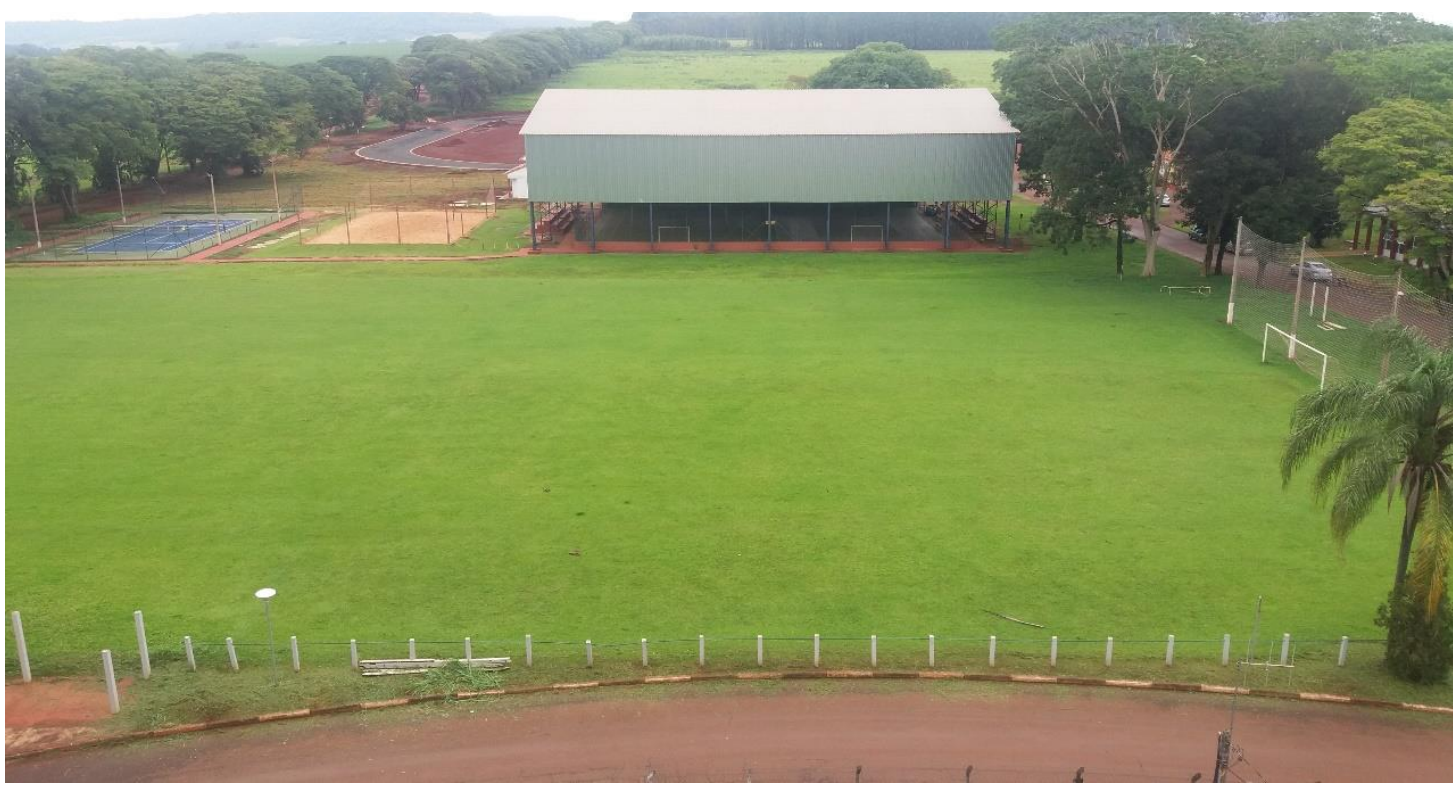


lateral esquerda do Prédio Central foi construído um complexo esportivo (figura 81), que tem origem no campo de futebol existente desde os anos 1950. Há duas quadras cobertas em uma estrutura metálica de grande porte, uma pista de atletismo recéminaugurada e algumas outras instalações, como a própria sede da SEF.

Na região conhecida como "Estrada do Povo", já bastante modificada pela construção e duplicação da Rodovia Anhanguera, vários edifícios foram completamente descaracterizados. Ali, a exceção são os edifícios em condições originais ou próximas do original. A implantação também foi profundamente modificada: o eixo original foi desviado e os edifícios são acessados por ruas marginais e porte-cocheres. Também foram construídos alguns novos edifícios, destacando-se o Bloco Didático de Nutrição Animal (BDNA), de salas de aula e laboratórios, construído entre 2011 e 2013 (figura 82).

Figura 82: Mapa da área da Estrada do Povo indicando os prédios acrescentados (em vermelho) e planejados (em verde).

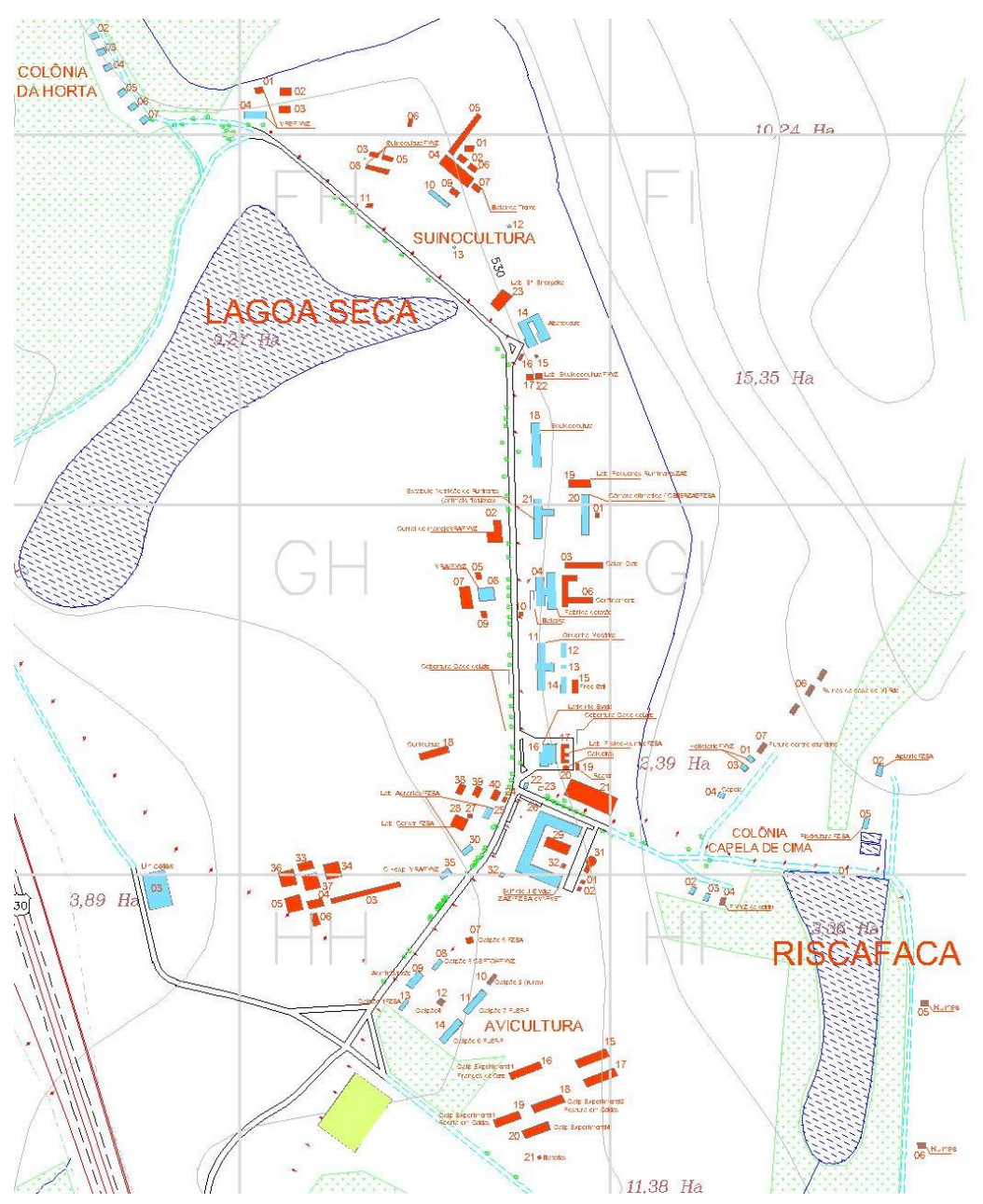

Fonte: cadastro SEF com intervenções do autor.
É possível constatar que a área que foi objeto de planejamento (o Plano Diretor da FZEA, que coincide com a área do antigo Parque de Exposições) está relativamente organizada, com vários elementos (prédios e infraestruturas) executados e outros ainda planejados ou previstos. Mas também há algumas intervenções pontuais não previstas, ainda que menos significativas quanto à área construída. O plano é entendido pelos dirigentes e pelos técnicos como um processo e não como um desenho estanque. Está 
sendo modificado e atualizado com alguma frequência e é observado pelos dirigentes dos órgãos e pelos técnicos responsáveis por decisões que impactam na área gerenciada pelo Plano.

Já as áreas que não foram abordadas pelo plano seguem sendo alteradas conforme decisões institucionais, tomadas pelos dirigentes ou pelos líderes locais (chefes de departamentos, chefes de laboratórios, etc), com pouca ou nenhuma consideração técnica e pouca ou nenhuma visão de conjunto. Os representantes dessas instâncias intervêm em seus territórios sem considerar a vizinhança ou a préexistência de infraestruturas similares. Em menor escala, os laboratórios idem. Assim, Figura 83: Portaria nova e portaria antiga, antes da obra inacabada do restauro.

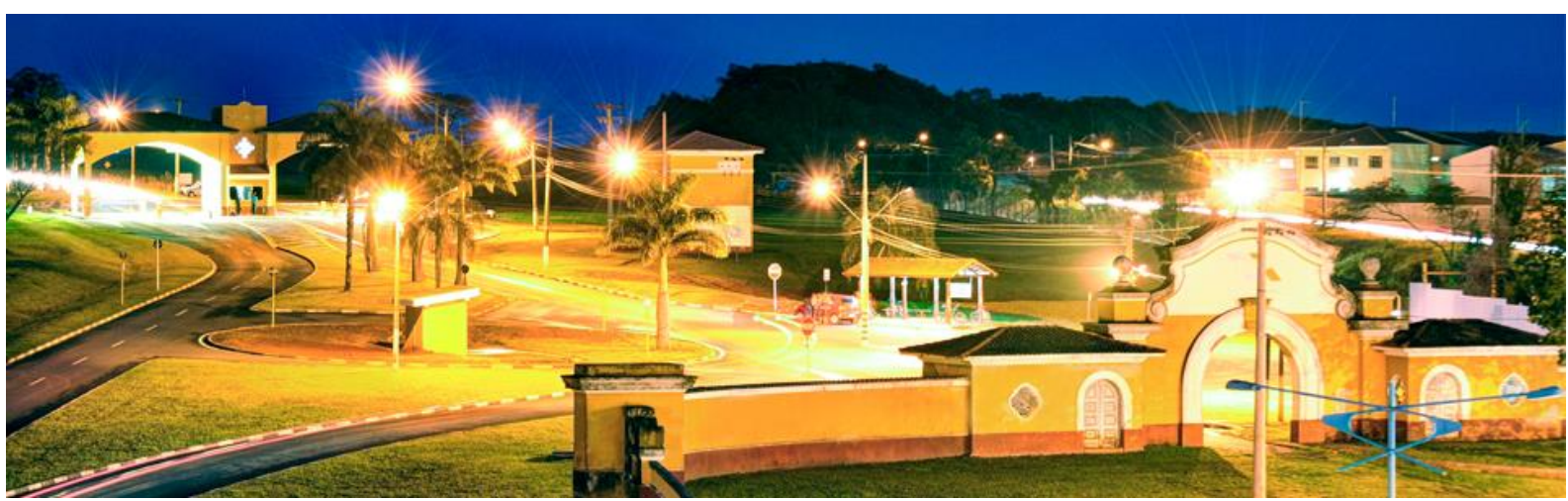

Fonte: Rodrigo Mangetti

Figura 84: Obra de restauro do antigo portal.

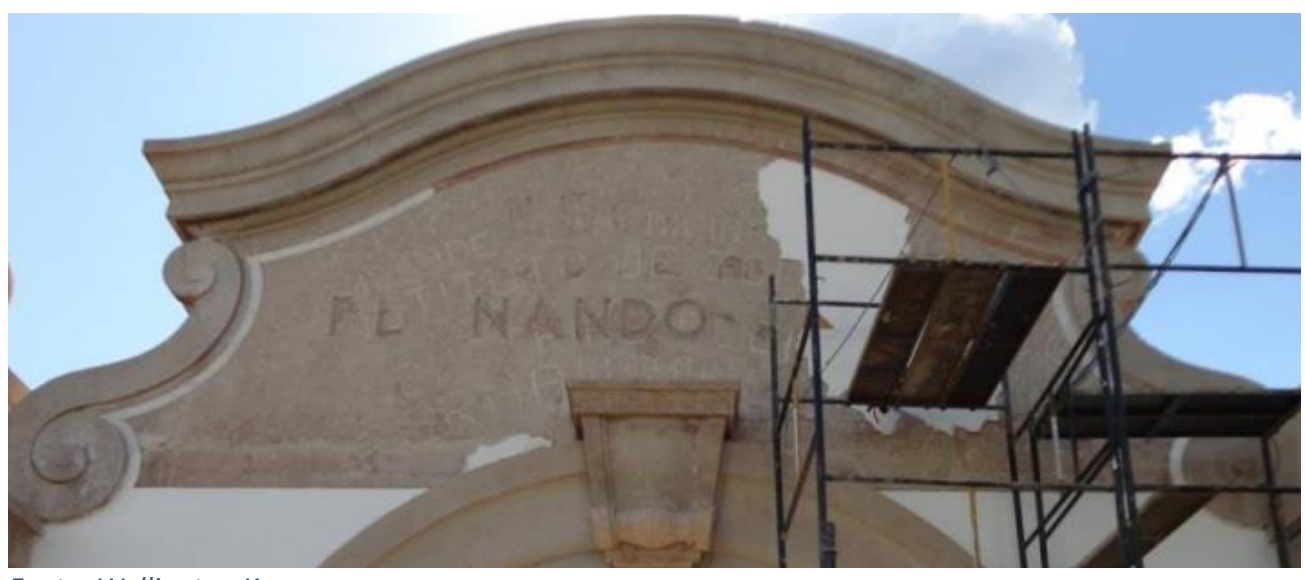

Fonte: Wellington Kanno

esse pensamento equivalente ao sentimento de "propriedade" de "lotes" vai se reproduzindo e produzindo o espaço.

$\mathrm{Na}$ área frontal do Campus, onde há o encontro com a cidade, também aconteceram algumas intervenções importantes. A antiga portaria era o único local de acesso, desde a duplicação da Via Anhanguera. O vão central, em formato de arco 
pleno, é estreito para a passagem de dois veículos (o vão luz possui cinco metros de largura). Por esse motivo, no ano de 2005, foi realizada pela Prefeitura do Campus uma abertura lateral na cerca, criando um novo acesso de veículos, por meio de uma área com pavimentação asfáltica conectando a Avenida Duque de Caxias Norte, no trecho já duplicado, ao eixo principal interno ao Campus. Para o controle de acesso (com a instalação de cancelas) e abrigo dos seguranças foi construído um novo portal, com arquitetura que deveria remeter à arquitetura neocolonial do campus. O projeto é de autoria de um engenheiro civil local de Pirassununga, Luís Henrique Barbirato, datado de outubro de 2002. O edifício é estruturado com peças metálicas, revestido com alvenaria e coberto com telhas cerâmicas (figuras 83 e 84). Possui altura maior que o antigo portal, o que permite ser visto desde o lado externo do Campus - porém a distância reduz essa perspectiva (o antigo portal tem 8,6 metros de altura contra 8,7 metros do novo, porém este possui altura livre de 6,2 metros) ${ }^{259}$.

O novo portal e o controle de acesso são elementos típicos da universidade operacional. A existência de um ponto de controle de acesso, ainda que este permita a entrada de qualquer cidadão durante o horário de funcionamento da Universidade, inibe a entrada do cidadão não vinculado à instituição. Não há qualquer indicação que o espaço é de livre acesso ou sequer de que o lugar o público. A comunidade residente nas vizinhanças raras vezes se apropria do espaço, mesmo sendo extremamente carente em equipamentos públicos de lazer.

O entorno é composto por bairros essencialmente residenciais, com alguns eixos de uso misto comercial e residencial. Os bairros possuem nível socioeconômico de médio para baixo. Alguns desses bairros foram empreendidos pelo governo estadual, por meio da Companhia de Desenvolvimento Habitacional e Urbano (CDHU) e outros por iniciativa privada ${ }^{260}$.

Considerando que a localização específica da universidade é um importante fator de definição de sua cultura ${ }^{261}$, podemos inferir que esse controle que a Universidade impõe, que reduz as relações com o seu entorno imediato, é uma opção deliberada por excluir de sua convivência a comunidade que não está diretamente

\footnotetext{
259 As informações referentes a essa intervenção constam dos processos administrativos 2005.1.13849.1.4 e 2004.1.499.19.1.

260 Informações verbais fornecidas na Secretaria de Planejamento do Município de Pirassununga.

261 Mc CLELLAND (1988), pg. 291.
} 
relacionada com ela própria. Há, no entanto, serviços oferecidos à vizinhança: cursos de línguas e de música, atendimento no Hospital Veterinário, além da utilização do espaço como área de lazer. Mas o impacto dessas atividades é mais ligado a própria comunidade acadêmica. Bom exemplo são os cursos de línguas e de música, que atendem qualquer cidadão, vinculado ou não com a Universidade. No ano de 2016, dos 953 alunos atendidos nesses cursos, apenas 190 (ou 20\%) não são pertencentes à comunidade acadêmica (alunos ou funcionários) ${ }^{262}$. Como vemos, a USP, fundada como uma instituição de formação das elites paulistas, mantém ranços dessa ideologia.

As intervenções na área de acesso ou área frontal do Campus não pararam por aí. Já não era recente o interesse da Prefeitura do Município de Pirassununga em duplicar a Avenida Duque de Caxias Norte - o antigo eixo do Caminho do Anhanguera, caminho substituído pelo eixo que cindiu ao meio o território estudado. Porém o espaço pertencente à Prefeitura, destinado para a duplicação, era insuficiente. Para a realização da obra, seria preciso adentrar no terreno da USP e demolir parte do antigo portal. Para evitar um longo parêntesis, destacamos o assunto a seguir.

3.4.1 A terceira transformação da paisagem: duplicação da Avenida Duque de Caxias Norte

O caso que detalharemos a seguir é exemplar do modus operandi da universidade pública brasileira - e em particular a USP - da maneira como é realizada a gestão de seu território. Por um lado, uma miríade de trâmites burocráticos, alguns indiscutivelmente essenciais, outros proforma e alguns pouco justificáveis; por outro lado a diminuta discussão democrática, mesmo nas câmaras e departamentos técnicos.

O caso ocorre entre 2005 e 2009 e refere-se à terceira grande transformação da paisagem: a duplicação da Avenida Duque de Caxias Norte pela Prefeitura do Município de Pirassununga. A cidade cresceu no sentido norte, com loteamentos implantados ao longo do eixo do antigo Caminho do Anhanguera, ultrapassando a

\footnotetext{
262 Dados fornecidos pela Divisão de Atendimento à Comunidade (DVATCOM) da Prefeitura do Campus Fernando Costa.
} 
portaria da USP (figura 85). Alguns desses bairros foram construídos por iniciativa do poder público estadual, como o Jardim São Lucas e o Jardim Redentor, inaugurados em 1992 com 550 unidades $^{263}$. Em 2000, residiam na zona norte quase 10.000 pessoas. Já pelo censo de 2010 ali viviam 13.419 pessoas. O resultado desse crescimento foi o congestionamento da referida Avenida (figuras 86 e 87 ).

A situação ensejou estudos para a duplicação da principal (e na época, a única) via de acesso a essa região da cidade. O Departamento de Trânsito da Prefeitura do Município de Pirassununga realizou estudos que previam a duplicação da Avenida ou a construção de um sistema binário, seguindo os eixos existentes no centro da cidade 264. Em ambos os casos, a USP deveria destinar parte da sua propriedade para a execução da obra.

O início dos trâmites se dá em agosto de 2001, com o encaminhamento de um ofício do Prefeito do Município, João Carlos Sundfeld, para o Prefeito do Campus, Figura 85: Situação da USP e da Zona Norte.

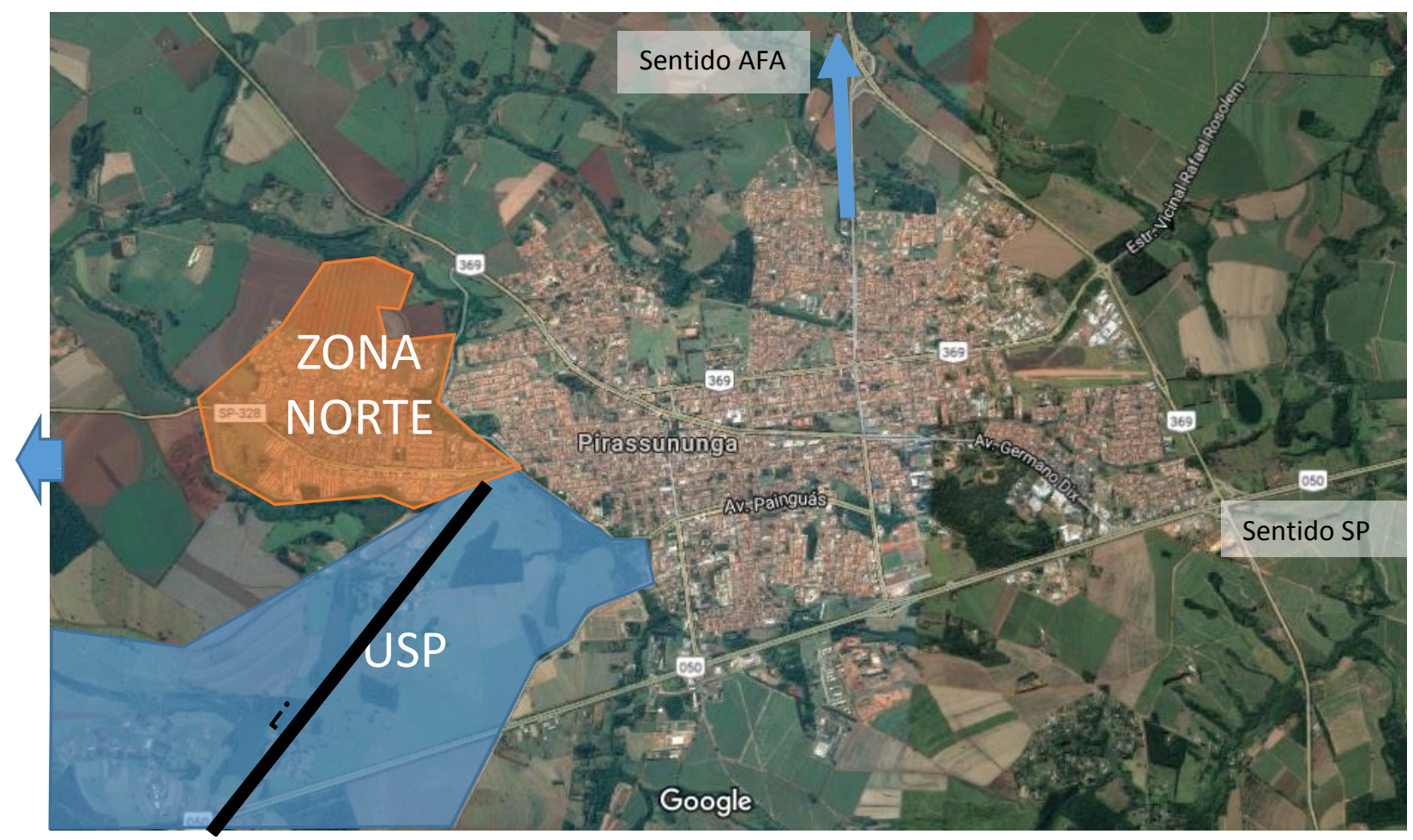

Fonte: Google Earth, com intervenções.

263 O sítio da CDHU na internet (www.cdhu.sp.gov.br ) possui uma ferramenta para verificar a produção habitacional da empresa. Acessado em 23/01/2017.

264 A primeira opção foi efetivamente executada e a segunda opção aparece apenas em um levantamento topográfico realizado pelo $\mathrm{Eng}^{\circ}$ Agrimensor João Ladislau Neto, que também era (e é) funcionário da Prefeitura do Município de Pirassununga. 
prof. Ricardo de Albuquerque, solicitando a doação da área, oferecendo como contrapartida um novo muro e as obras viárias de acesso ao Campus ${ }^{265}$.

Em setembro de 2001, com o encaminhamento de um projeto da Prefeitura do Município para a Prefeitura do Campus, confeccionado pelo Secretário de Planejamento do Município, o arquiteto José Luiz Pereira de Godoy Júnior. Neste projeto há apenas uma menção ao portal, que aparentemente teria apenas sua porção central preservada (ANEXO 3). O projeto foi analisado por funcionários técnicos do antigo Fundo para a Construção da USP (FUNDUSP), depois renomeado para Coordenadoria do Espaço Físico (COESF) e atual SEF. Os funcionários (arquiteto Gabriel Sister e arquiteta Neyde A. J. Cabral) redigiram um parecer solicitando a revisão do projeto, de maneira a preservar integralmente o portal e também os muros ao redor e para melhorar o desenho geométrico, facilitando o trânsito e a entrada e saída da USP. Porém desenharam uma alternativa sobre a base cadastral existente, o que igualmente exigiria a demolição parcial do Portal (ANEXO 4). Ambos são favoráveis à intervenção, considerando a expansão urbana significativa no vetor norte.

Em 07 de fevereiro, já no seguinte anos de 2002, a arquiteta Ivone Rafael, do Instituto de Avaliações e Perícias de Engenharia (IBAPE), redigiu um Laudo Técnico

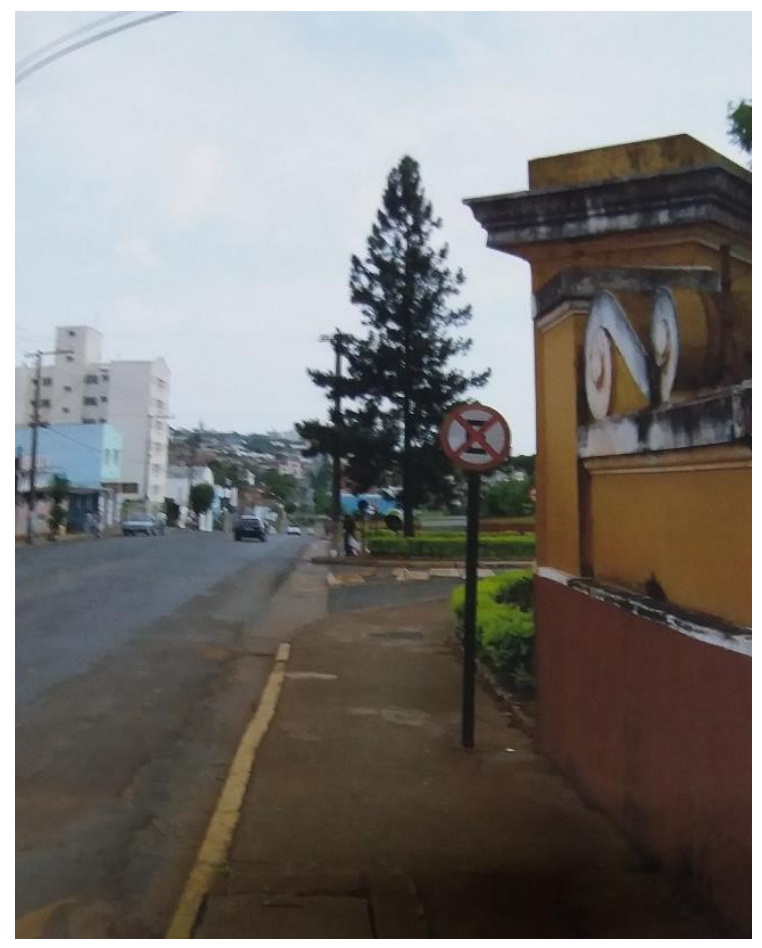

Figuras 86 e 87: A Avenida Duque de Caxias Norte antes da duplicação.

Fonte: Relatório do Grupo FAU/EESC.

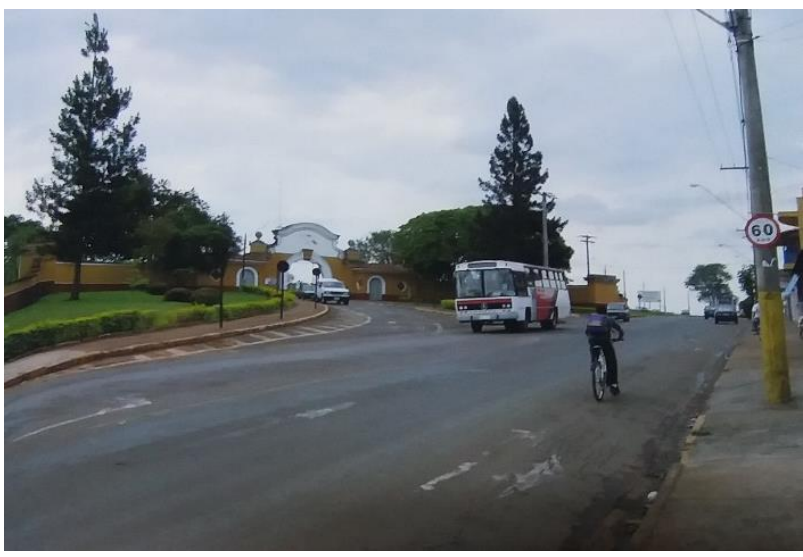

265 Todas as informações referentes aos trâmites dessa obra foram retiradas do processo administrativo 2001.1.240.19.5. 
de Avaliação para quantificar o valor da área, já que a Prefeitura do Município se prontificara a compensar este valor com prestação de serviços (pavimentação, por exemplo). O valor, naquele período, alcançava os $R \$ 150.000,00$. Apesar do foco na questão imobiliária, o Laudo já considerava a permanência do portal, com exceção de parte do muro no trecho paralelo à avenida.

A Prefeitura do Campus, nesse momento já ocupada pelo Prof. Marcus Zanetti, ao receber o laudo, confeccionou um projeto de pavimentação no valor do imóvel e encaminhou ofício à Prefeitura do Município autorizando o trâmite, porém solicitando contrapartida em obras, no valor determinado no laudo. O ofício foi prontamente recebido e aprovado.

O novo Prefeito do Campus demonstrou interesse pela obra, como pode ser observado no ofício encaminhado ao Reitor, prof. Adolpho Melfi, dez dias após a recepção da aprovação da Prefeitura do Município. Nesse ofício, o professor descreve os trâmites e informa que a obra foi aprovada no Conselho do Campus, em reunião de 27 de fevereiro. Defende a obra com o argumento da facilitação do acesso ao Campus e "a redução de riscos de acidentes no local, uma vez que pela intensidade do trânsito e pela precariedade atual, diariamente os usuários do campus são submetidos a situações de risco". O mesmo argumento aparecerá um ano depois, em Ofício encaminhado pela assistente social da Prefeitura do Campus ao Prefeito do Campus, e será utilizado como forma de apoio à realização da obra.

Em maio de 2002 o reitor encaminhou o processo à Procuradoria Geral (então ainda denominada Consultoria Jurídica), órgão que analisa juridicamente os trâmites da Universidade. O órgão considerou adequada a permuta entre a área solicitada e os serviços oferecidos, entretanto exigindo o detalhamento de ambos e a tramitação por Câmaras especializadas e pelo Conselho Universitário, o órgão máximo da Universidade.

Um ano depois, já em maio de 2003, o Prefeito do Município encaminha um novo ofício, anexado com requerimento da Câmara dos Vereadores, solicitando a doação da área em questão. Em junho encaminha um terceiro ofício, considerando "perfeitamente viável" a manutenção da portaria existente e aceitando a permuta. Esse ofício é encaminhado para a Procuradoria Geral, que ao término de análises consecutivas oferece uma Minuta de Termo de Permuta e pede à Prefeitura do Campus a elaboração de um projeto executivo, com planilha orçamentária, 
cronograma e memorial descritivo. Em outubro de 2003 o Prefeito do Campus encaminha ofício para o Prefeito do Município (cargo já ocupado por Darcy Franco da Silveira), pedindo parecer do Termo de Permuta e aceitando, portanto, a proposta encaminhada em maio pelo Prefeito anterior.

No mês seguinte, novembro de 2003, o Prefeito do Município encaminha ofício concordando com o Termo de Permuta, baseado em Laudo Técnico de Avaliação próprio, restando, portanto apenas a aprovação nas Câmaras e no Conselho Universitário, pelo lado da USP; e pela Câmara dos Vereadores, do lado da Prefeitura Municipal. A aprovação do município se conclui em abril de 2004, no corpo da Lei Municipal № 3265 de 29/04/04. A aprovação nas Câmaras da USP acontece em agosto de 2004, mas o trâmite no Conselho Universitário recomendou que o Centro de Preservação Cultural (CPC) da USP e a Faculdade de Arquitetura e Urbanismo (FAU) se manifestassem sobre o assunto.

Em setembro acontece a reunião no $\mathrm{CPC}$ e, como resultado, a professora Ana Lúcia Duarte Lanna redige uma Informação, cujos termos merecem ser reproduzidos na íntegra.

"Todo esse complexo está estruturado por um grande eixo que liga a portaria ao edifício central... e constitui um dos mais significativos conjuntos do chamado neocolonial brasileiro assim como um patrimônio ambiental de inestimável significado.

Assim sendo, e tendo em vista o rico patrimônio herdado pela Universidade, se faz necessário a adoção de critérios no momento de se intervir em um complexo edificado dessa natureza... salientamos que, embora até o momento este conjunto não seja bem tombado pelos órgãos oficiais de preservação, o Campus de Pirassununga bem como suas edificações constituem relevante patrimônio cultural e ambiental da Universidade. Quando forem necessárias intervenções, seja em seu conjunto arquitetônico, seja em suas edificações isoladas para realização de inserções de novos edifícios ou modificações em seu sistema viário, deverão ser adotados critérios que priorizem a manutenção da integralidade deste patrimônio da Universidade."

E segue observando que sequer há precisão na locação do portal de acesso e que o projeto é insuficiente. Recomenda a realização de um levantamento planialtimétrico preciso e apoia a permuta, condicionada à revisão do projeto, preservando integralmente o portal, mantendo sua função original e assim também mantendo seu papel de "elemento definidor do eixo estruturador do conjunto do campus". 
Na FAU e na EESC foi formado um grupo de trabalho para análise do caso. $O$ grupo foi composto pelos professores José Eduardo de Assis Lefévre e Nuno de Azevedo Fonseca, representando a FAU e, representando o então Departamento de Arquitetura da EESC (atual Instituto de Arquitetura e Urbanismo - IAU), os professores Carlos A. F. Martins e Carlos Roberto Monteiro de Andrade. Como observadores, participaram o professor da FAU Sylvio Sawaya e a arquiteta Neyde A. J. Cabral. O grupo visitou o local e redigiu, em outubro, um relatório, introduzido por uma leitura precisa dos fatos e da história do Campus, assunto já tratado nessa Dissertação. Foi feita uma leitura urbana do entorno e das relações entre o território universitário e a cidade. Há uma passagem que afirma que "seccionar os muros iria amesquinhar o conjunto e roubar-Ihe o nexo próprio". Como alternativa para a demolição parcial do conjunto, os professores indicam duas possibilidades de realização da obra:

1) Por outro eixo, paralelo à Avenida Duque de Caxias Norte, com menores custos de desapropriação, seguindo o modelo binário que vem do centro da cidade;

2) Por outro eixo, paralelo à Avenida Duque de Caxias Norte, pelo lado interno do campus, sem qualquer demolição e ocupando uma faixa de área equivalente à solicitada pela Prefeitura do Município. Essa solução exigiria a construção de uma nova portaria e resultaria em uma quadra urbana de propriedade da universidade, que ali poderia instalar os equipamentos que possuem maior interface com a cidade.

Enquanto o grupo da FAU/EESC se encontrava, o levantamento planialtimétrico foi concluído (ANEXO 5). Com base no relatório da FAU e neste levantamento, a COESF realizou dois projetos, assinados pela arquiteta Neyde A. J. Cabral. A primeira, em consonância com as propostas dos professores, e a segunda é uma releitura da proposta (ANEXOS 6 e 7, respectivamente). Ambas as propostas resultam em espaços muito melhores do que a efetivamente executada, dos pontos de vista urbano, ambiental, paisagístico, patrimonial e arquitetônico. Ambas as propostas foram referendadas pelo CPC, em março de 2005.

Na reunião do Conselho Universitário, em 31 de maio de 2005, a proposta de permuta com a Prefeitura do Município foi votada. Com 79 votos favoráveis e 1 contrário, a permuta foi autorizada, nos termos do parecer do CPC. Depois, em agosto 
de 2005, foi também aprovada no Conselho do Campus. A permuta, de fato, aconteceu. Porém as propostas citadas nos termos do parecer do CPC não venceram.

As soluções propostas pelos professores do grupo da FAU/EESC começam a se alterar em desenho sem assinatura, da Prefeitura do Campus, datado de agosto de 2005 (ANEXO 8). Ali surge uma alternativa que preserva quase integralmente o conjunto arquitetônico. Um sistema que envolveria o portal em uma rotatória, com duplicação apenas parcial da Avenida Duque de Caxias Norte. Em setembro essa proposta é comentada pelo CPC, que propõe o desnivelamento do acesso, enterrando parcialmente a rotatória e mantendo o portal na íntegra (ANEXO 9). Segue-se um imbróglio de encaminhamentos e idas e vindas do processo, com comentários sobre cada uma das opções. Um, em especial, merece citação na íntegra. Em junho de 2006, o grupo da FAU/EESC afirma:

\footnotetext{
"O grupo de trabalho manifesta desconforto com o encaminhamento da questão, pois entende que permutas de áreas públicas devem ser baseadas em definições e descrições precisas em plantas e escrituras, necessárias para as devidas inscrições em Registros Imobiliários, de forma a evitar prejuízos ou pendências futuras."
}

Em fevereiro de 2007 desaba parte do muro frontal, após uma noite de chuvas

Figura 88: Fotos da queda do muro, constantes do processo.

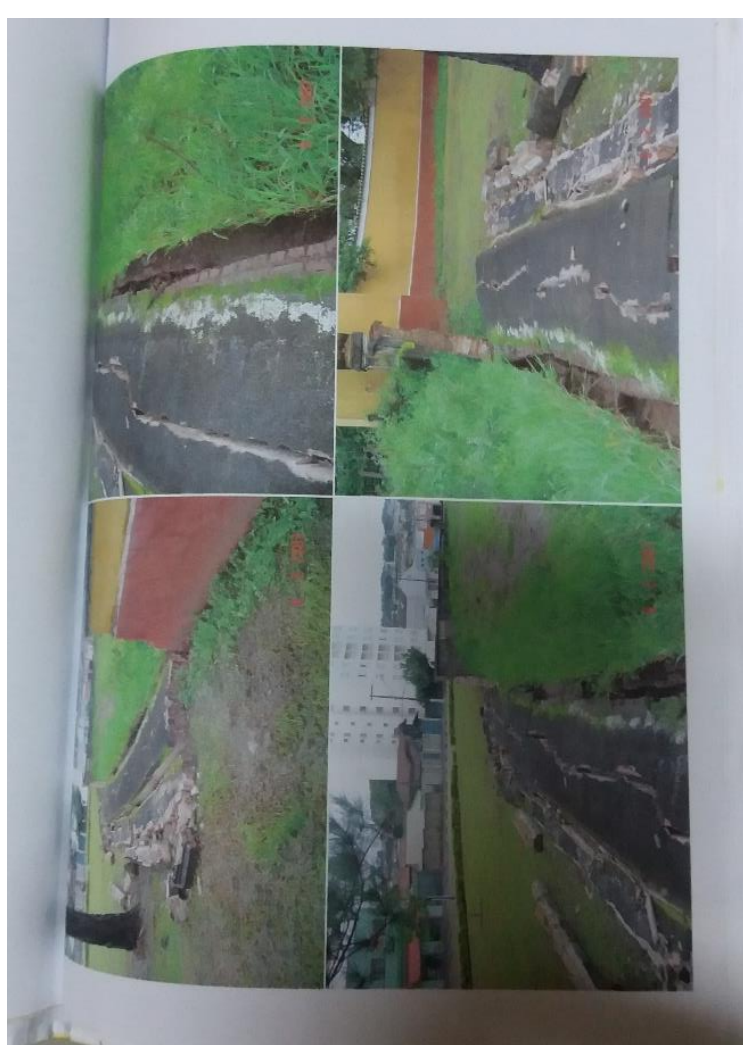

Fonte: fotos constantes de relatório assinado pelo Eng. Carlos Henrique Dutra. (figura 88). Para acelerar o processo, a Prefeitura do Campus confecciona um projeto que atende às recomendações da COESF e da CPC, apesar de diferir das propostas dos professores do grupo da FAU/EESC. Essa proposta é encaminhada ao CPC, que em parecer técnico de dezembro de 2007, a refuta. Uma nova equipe de análise aparece nesse órgão, composta pela professora Maria Lucia Bressan Pinheiro, arquiteto Rogério Bessa Gonçalves e professor Felipe Kabbach Jr. Essa equipe propôs um desenho muito próximo do que foi efetivamente executado, levando em consideração a ruína parcial da chuva de fevereiro e colocando em primeiro lugar o argumento da continuidade física do 
portal com o território universitário, de maneira a não "ilhar" o edifício (ANEXO 10). Juntamente com a proposta, questiona sobre a restauração e manutenção do portal, se seria da Universidade ou da Prefeitura do Município - o que até o momento nunca havia sido questionado. Essa nova proposta é quase similar à proposta inicial da Prefeitura do Município, modificando apenas o ponto de acesso do território da USP. A preocupação com o restauro e manutenção do edifício é um fator questionável: aparentemente o desabamento parcial, oportuno para acelerar a obra nos moldes do projeto original da Prefeitura do Município, também ensejou a proposta do órgão que deveria ajudar a manter a integridade do bem. Essa proposta assume o desabamento e também causa a demolição de parte do outro lado do muro, amputando a obra arquitetônica e a separando da cidade, inserindo uma avenida expressa entre as duas áreas.

Em janeiro de 2008 a proposta é aceita pela COESF e pela Prefeitura do Campus, agora ocupada pelo professor Marcelo M. L. de Oliveira Ribeiro, com a sugestão de alteração do eixo de acesso à universidade (da cota mais alta para a cota mais baixa, do lado oposto do portal) e mais alguns detalhes executivos, como a manutenção dos traçados antigos, etc. Essa alteração foi efetivamente executada em projeto do mesmo mês, da autoria da arquiteta Neyde A. J. Cabral, e resultou em mais um bloqueio viário à visitação e fruição do edifício (Anexo 11). Estaria agora separado da cidade por uma avenida expressa e distante do território universitário por um complexo de acesso.

Finalmente, em dezembro de 2008, é assinado o termo de permuta, com descrição assinada pelo Engenheiro Agrimensor João Ladislau Pinto (autor de alguns dos projetos, do levantamento planialtimétrico e simultaneamente funcionário da Prefeitura); pelo Prefeito de Pirassununga, Ademir Alves Lindo e pelo Reitor da USP, professor Adolpho José Melfi.

Pouco antes da formação do grupo da FAU/EESC, em dezembro de 2003 aparecem os primeiros desenhos referentes aos levantamentos planialtimétricos das áreas a pavimentar, que seriam a contrapartida da Prefeitura do Município. Alguns desses desenhos não apresentam informações suficientes para identificarmos os locais das obras, enquanto outros indicam locais que foram efetivamente asfaltados e locais que até hoje não possuem pavimentação deste tipo. Em 2009, subsequente às obras da duplicação da Avenida Duque de Caxias Norte, o novo acesso à USP em 
Pirassununga foi pavimentado (as figuras 89 e 90 apresentam o complexo antes e depois da intervenção). A área total de pavimentação foi de 2.651,7 m2. Faltavam $3.660,75 \mathrm{~m} 2$ de pavimento asfáltico, o preço cobrado pela universidade para sua cisão da cidade.

Enfim, a solução executada exigiu a demolição parcial do portal do acesso, um edifício marcante, que é símbolo da USP em Pirassununga e aparece até no logotipo

Figura 89: Avenida Duque de Caxias Norte e acesso ao Campus, 2011.

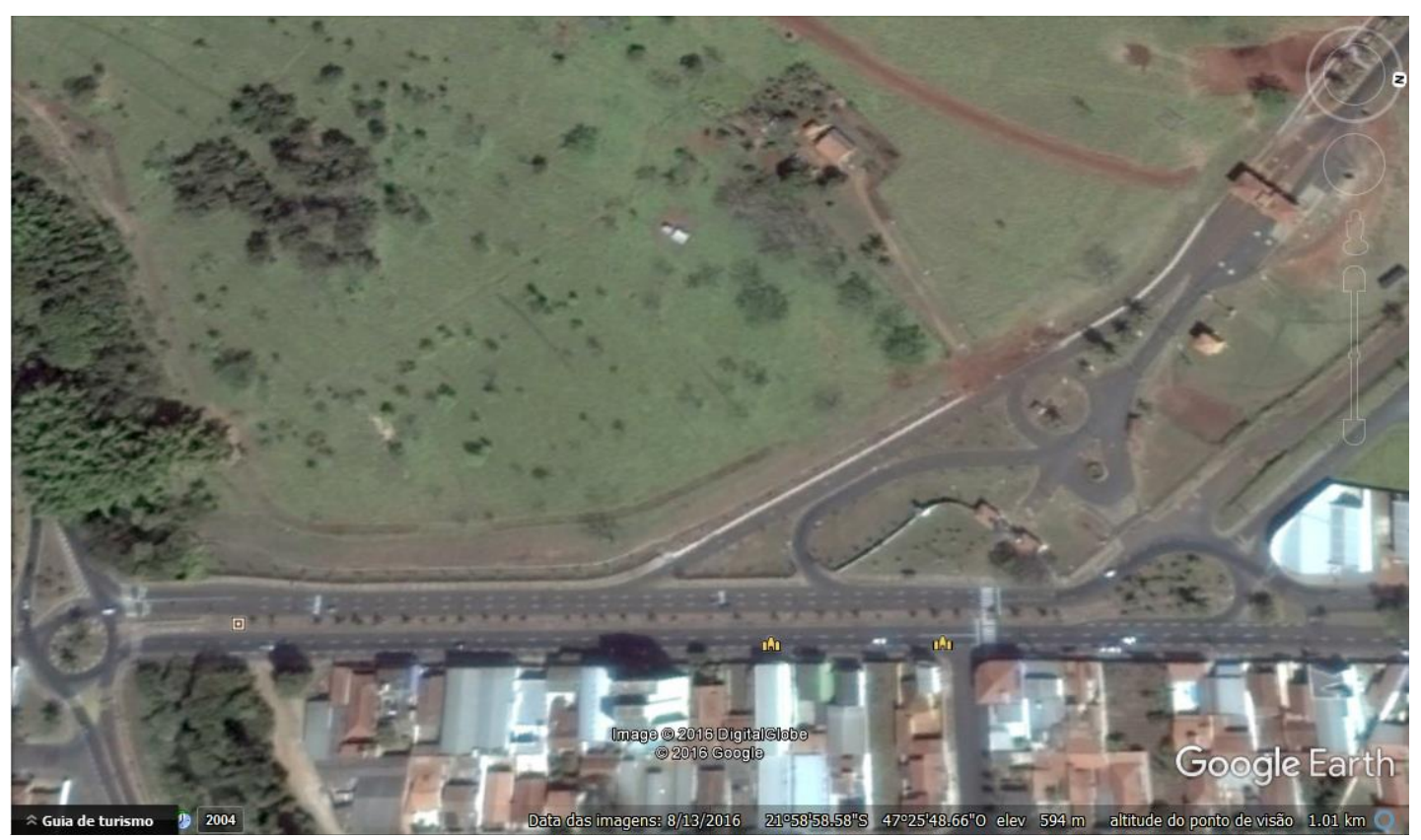

Fonte: Google Earth.

Figura 90: Avenida Duque de Caxias Norte e acesso ao Campus, 2004.

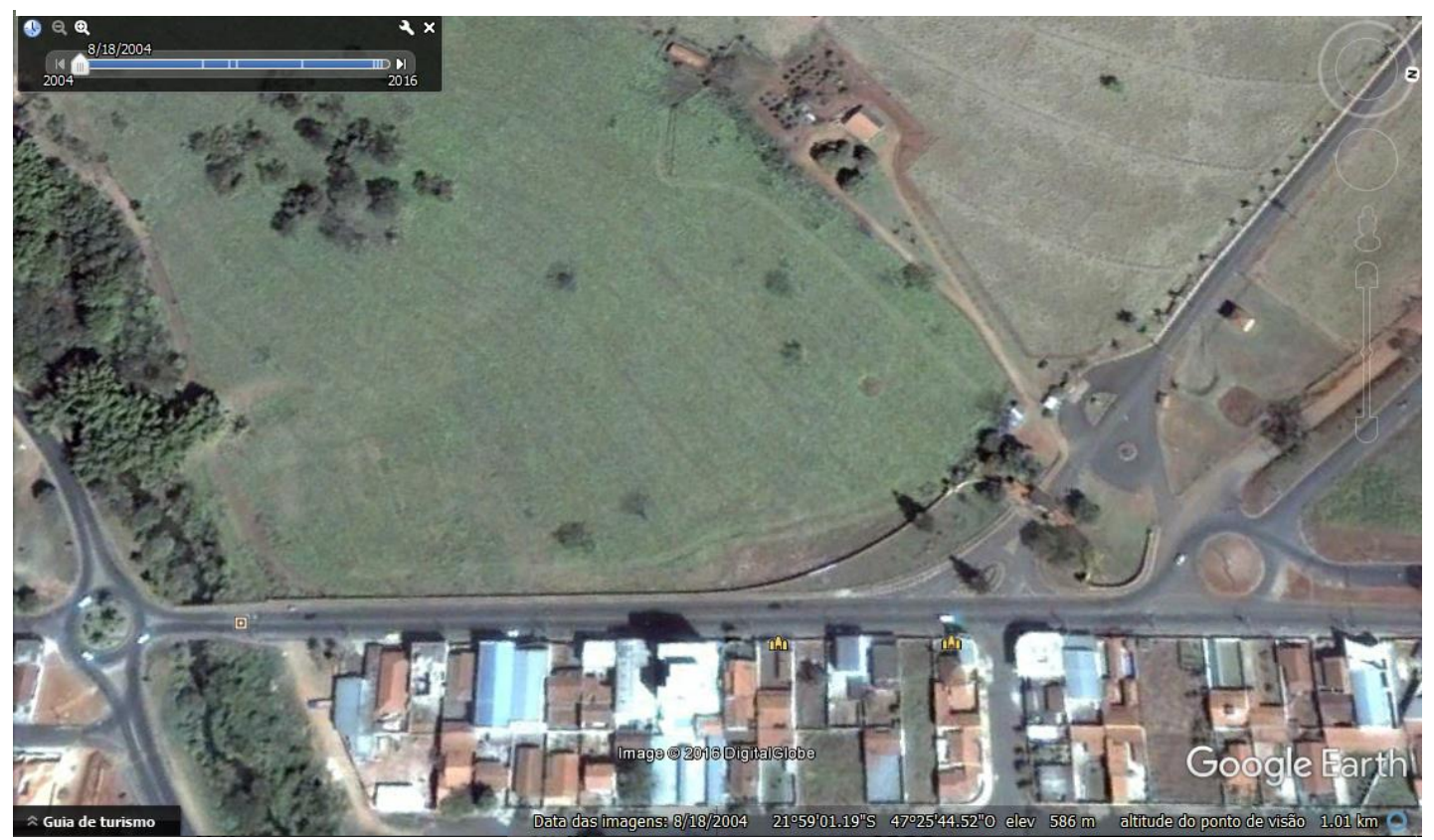

Fonte: Google Earth 
da Prefeitura do Campus, mesmo após as sugestões alternativas recomendadas nos processos administrativos internos. Novamente, decisões institucionais pouco transparentes ou pelo menos pouco democráticas se sobrepõem a qualquer planejamento, mesmo os realizados com urgência. A decisão, nesse caso, passando pelo gabinete dos órgãos, negava uma alternativa técnica que observasse a manutenção do edifício do Portal na íntegra, ou até valorizando-o. Em nenhum momento as comunidades foram convidadas a opinar, seja na cidade, seja na universidade.

O resultado foi o pior possível. O edifício do Portal, mutilado, foi se degradando rapidamente ao longo da obra (danificando parcialmente suas fundações) e nos meses posteriores. Intervenções emergenciais para recuperar as fundações foram realizadas ${ }^{266}$. A situação de abandono motivou a Prefeitura do Campus (sob o mesmo comando do período da obra de duplicação) a proceder o restauro, de acordo com a melhor técnica. Com o projeto executado pela empresa Diegoli e Magaldi, a obra foi licitada e iniciada pela empresa Cafema Ltda. (falida poucos anos depois), que não concluiu o serviço por incapacidade técnica (figura 84) 267.

O novo sistema viário de acesso, que substituía a abertura na cerca (que já era uma substituição do vão central do Portal), com o tempo mostrou-se inadequado. $O$ território uspiano em Pirassununga é frequentado por máquinas e caminhões de grande porte, que para realizar a curva de acesso desse novo sistema viário necessitam invadir a pista do sentido contrário, bloqueando o trânsito ou causando riscos aos usuários.

Está pendente a retomada do restauro e o redesenho geométrico do sistema viário de acesso. Segundo a Prefeitura do Campus e a Superintendência do Espaço Físico (SEF), órgãos da USP que poderiam se responsabilizar pela obra, a atual crise financeira exige priorizações e há necessidades mais urgentes na atualidade ${ }^{268}$.

\footnotetext{
${ }^{266}$ Com o acompanhamento do Eng ${ }^{\circ}$ Carlos Henrique Dutra, que nos apresentou os detalhes da obra. 267 Tivemos a oportunidade de acompanhar essa contratação e auxiliar na fiscalização da obra.

268 Amplamente divulgado na mídia, por exemplo na nota a seguir, publicada no portal G1 Educação. http://g1.globo.com/educacao/noticia/2014/04/em-crise-financeira-usp-anuncia-suspensao-de-obrase-contratacoes.html. Acessado em 05/02/2017.
} 


\subsection{Dificuldades: a expansão do espaço físico e sua relação com a universidade}

Thomas Bender, logo na introdução de "University and the City", afirma que o objetivo dos estudos contemporâneos sobre a universidade devem ser a identificação de seu lugar e seus propósitos na sociedade atual, já que a amplitude da abordagem histórica da universidade permite dizer que há uma retórica superaquecida da crise. Concordando com essa afirmação, pretendemos contextualizar essa dissertação como um esforço para entender qual o atual papel da USP em Pirassununga.

Em alguns pontos desse texto aparece o conceito de "universidade operacional", que tem a ver com sua missão e seu papel na sociedade. Para defini-lo, é necessário um pequeno resgate histórico. É preciso, também, considerar que as especificidades das universidades situadas no ambiente rural não a excluem da explicação geral a seguir.

Um dos principais papeis da instituição Universidade, de sua origem até o período anterior à segunda guerra mundial, era o debate sobre o conhecimento, de forma multidisciplinar e integrada. Era frequentada por uma elite intelectual não necessariamente conectada com as elites políticas e econômicas ${ }^{269}$. No Brasil, o ensino superior surgiu fragmentado e especializado, tendo em vista o modelo colonizador português. Portanto o ideal de multidisciplinaridade e integralidade universitária não esteve presente na origem do ensino superior brasileiro. Somente no início do século passado as escolas de ensino superior tentaram superar a fragmentação. A fundação da Universidade de São Paulo (USP), em 1934, é exemplar: reuniram-se algumas escolas pré-existentes, principalmente de formação profissional, e para atingir um patamar universitário (no sentido da mencionada integralidade), foi criada uma unidade na qual o fim seria o debate sobre o saber fundamental (a Faculdade de Filosofia, Ciências e Letras [FFCL], hoje denominada Faculdade de Filosofia, Letras e Ciências Humanas [FFCLH]).

Até 1961 , antes da primeira LDB ${ }^{270}$, o acesso ao ensino superior acontecia por meio de um exame de admissão, no qual o "desenvolvimento intelectual" do candidato

\footnotetext{
269 MENEZES (2000) e WANDERLEY (1988).

270 As LDBs foram as seguintes leis: Lei Federal no 9394 de 20 de dezembro de 1996; Lei Federal nํㅜ 5692 de 11 de agosto de 1971 e Lei Federal no 4024 de 20 de dezembro de 1961.
} 
era avaliado ${ }^{271}$. Esse exame exigia um grau de conhecimento que a maior parte da população brasileira não atingia, ou ainda acessível apenas para uma elite econômica que teve acesso a educação fundamental de qualidade. O ensino desse período exigia erudição e domínio de línguas estrangeiras. A intenção principal do ensino superior era formar a elite dirigente do país. Após 1961, com a ampliação do ensino fundamental no país e o forte crescimento demográfico, a demanda cresceu exponencialmente. A carência de vagas (mesmo considerada a interiorização do ensino) obrigou a criação de um exame vestibular. O perfil do estudante e da própria universidade também se alterou, já que a industrialização e a urbanização do país exigia uma mão de obra altamente qualificada para o trabalho. Durante essa expansão, que continuou sob os auspícios da LDB do governo ditatorial, a educação em nível superior era a garantia de ascensão social.

No entanto, a formação da elite intelectual e da elite dirigente do país também necessitava de um lugar. A USP ocupava esse lugar, contando com os professores mais renomados, o exame vestibular mais concorrido e o aporte de maiores verbas, dentro de um projeto do governo paulista que, mesmo com eventuais alterações de comando, permaneceu até a promulgação da última LDB ${ }^{272}$.

A expansão do ensino superior continua até hoje, porém concentrada nas instituições privadas. A USP e as demais universidades públicas paulistas tornaramse instituições de grande porte, ainda que só ofereçam aproximadamente $7 \%$ das vagas de ensino superior em nível de graduação no Estado. É fácil verificar a dimensão dessas universidades: a pesquisa no Brasil cresceu 42\% de 2002 a 2008, enquanto o percentual das públicas paulistas nesse total esteve sempre em torno de $50 \%{ }^{273}$. Essas dimensões maiúsculas causaram uma transformação no perfil dessas universidades, que hoje ainda formam a elite intelectual e a elite dirigente do país, mas também fornecem profissionais para o mercado e o setor público. Mas esse quadro sofre algumas alterações nos últimos vinte anos. A principal novidade está na forma que a sociedade contemporânea percebe a instituição universidade: em primeiro lugar, a titulação universitária é vista como uma obrigação para almejar-se salários satisfatórios no mercado; em segundo lugar, a qualidade de uma universidade

\footnotetext{
271 Decreto No 8.659 de 5 de abril de 1911.

272 CHAUÍ (1994).

${ }^{273}$ FAPESP (2010).
} 
é avaliada, principalmente, com o uso de métodos comparativos, no mais das vezes quantitativos, inserindo a universidade (mesmo a pública) em uma lógica de competição capitalista, tipicamente neoliberal, o que a classifica como "universidade operacional" ${ }^{274}$.

O impacto dessa operacionalização é enorme. O quadro 1 apresenta dados referentes à USP. Depreendemos por ele que nos últimos vinte anos as vagas cresceram $62 \%$, enquanto o número de alunos de graduação na USP aumentou em mais de $76 \%$ e da pós-graduação em quase $50 \%$. O número de docentes aumentou $23,8 \%$ e de funcionários $18,7 \%$. A área construída cresceu $45,5 \%$. A relação de alunos para cada docente passou de 10,8 para 14,5. Finalmente, a arrecadação passou de 0,88 bilhão (1997) para 4,6 bilhões (2014), mas em valores reajustados o acréscimo é de 26,9\%, sendo que os valores de 1997 foram atingidos apenas em 2010.

Há decorrências óbvias, como a nítida sobrecarga de trabalho dos docentes, que lidam com um universo maior de alunos; o crescimento da área física é insuficiente para a população e a diversidade acrescentadas pelos cursos e campi novos; o orçamento que não acompanhou o crescimento da instituição. Mas há outras constatações menos óbvias, que não permitem que as conclusões sejam formuladas apenas por uma análise direta de dados tabulados.

A expansão da universidade, portanto, ocorre por sua "operacionalização". Essa dinâmica se estabelece devido às alterações do papel fundamental da universidade desde o advento da produção em massa e a especialização das profissões. Mais recentemente, após as transformações produtivas após a segunda guerra mundial, a construção do "indivíduo-empresa" o conduz para a exigência de formação profissional altamente qualificada (novamente parafraseando Laval e Dardot). A princípio na indústria e depois em todas as áreas da atividade humana, a formação profissional altamente qualificada foi delegada às universidades. Daí surgem as três crises que Boaventura de Souza Santos $(1997,2004)$ pontua em dois textos ${ }^{275}$, a saber:

A- Uma crise de natureza institucional, relacionada à autonomia universitária, que tem origem na necessária independência financeira da universidade pública. Essa

\footnotetext{
274 BOSI (2000) e ROSTOFF e DIAS SOBRINHO (2000).

275 SANTOS (1997) e SANTOS (2004).
} 
desejável independência vem sendo subtraída seguidamente. A alegação é que há instituições privadas que oferecem o mesmo "produto" desejado pela sociedade para a desenvolvimento individual do cidadão: a qualificação profissional. Em segundo lugar, pela vinculação da pesquisa desenvolvida na universidade aos interesses das empresas privadas, que assim podem injetar verbas na primeira. Essas condições ocorrem não apenas na educação, mas também na saúde e outros direitos sociais, devido à premissa neoliberal do "Estado Mínimo", que libera atividades antes exclusivamente estatais para a iniciativa privada. Outra face desse processo é a transnacionalização da educação superior, com a criação e ampliação de grandes conglomerados universitários, mais "eficazes" e "ágeis" para adequar sua oferta às necessidades do capitalismo contemporâneo. E também, é importante dizer, que a educação é um negócio, nos números do Banco Mundial apresentados por Boaventura de Souza Santos, duas vezes maior que o mercado automobilístico. 0 auge dessas transformações é a percepção de que a Universidade (pública ou privada) é uma instituição que oferece um serviço como qualquer outro, devendo ser regida pelas leis do mercado, compreendida como uma "empresa". Nesse momento, que talvez ainda não tenha sido atingido (tanto na época que o autor escreve, em 2004, como hoje), não faria sentido diferenciar a universidade pública da privada, tornando-se essa uma questão puramente retórica.

B- A segunda crise seria uma crise de legitimidade, que é vinculada à primeira, mas não causada apenas pelos mesmos motivos. Essa crise ocorre devido às pressões da sociedade no sentido de democratizar o acesso ao ensino superior, com a universalização, por exemplo. Esse acesso é impossibilitado tanto pela inexistência de vagas para todos, como pelos critérios de seleção (credenciamento de competências). A própria hierarquização de saberes, presente na história da universidade, estaria em cheque. Dessa forma desaparece o consenso sobre a efetividade da universidade como lócus dessa universalização.

C- A terceira crise é igualmente decorrente da primeira, e trata-se de uma crise contraditória entre a autonomia universitária, que preconiza a decisão sobre os deveres e objetivos da universidade, e as pressões da sociedade (induzidas pelo mercado e pela necessidade contemporânea de consumo) por uma instituição mais eficaz e produtiva, sob uma análise com critérios empresariais. 
Para explicar como essa primeira crise se apresenta no Brasil, vejamos alguns dados. Em nosso país, a relação de vagas entre instituições privadas e públicas é de $73,55 \%{ }^{276}$. Há uma disputa ideológica, que até meados dos anos setenta esteve entre as universidades públicas e as confessionais ${ }^{277}$. Desde então, as universidades empresariais se ampliaram ao sabor da demanda do mercado, com frouxo controle estatal, gerando uma evidente tensão. Em São Paulo, as universidades públicas também cresceram consideravelmente (os números apresentados no Quadro 1 são exemplares), mas muito abaixo do índice de crescimento das instituições privadas. Em dados de 2013, as matrículas das públicas computam aproximados $15,9 \%$ do total, das quais $10,5 \%$ nas estaduais 278 .

O financiamento das universidades públicas paulistas é composto, principalmente, por repasses de um percentual do Imposto sobre Circulação de Mercadorias e Serviços (ICMS), cuja arrecadação é diretamente relacionada com o consumo. O percentual mínimo fixado em Decreto de 1989 é de 8,4\%, mas desde 1995 está fixado em 9,57\%, a despeito do crescimento previamente apresentado ${ }^{279}$. Ou seja, a arrecadação flutua anualmente ao sabor da "economia de mercado", e os recentes recordes orçamentários (2013 e 2014) são puro reflexo de um momento histórico no qual o consumo e a economia interna do país estavam em relativa alta.

\footnotetext{
276 Dados INEP/MEC, 2013.

277 BAUER (2010).

278 Dados INEP/MEC, 2013.

279 BIANCHI (2008).
} 


\begin{tabular}{|c|c|c|c|c|c|c|c|c|c|}
\hline \multicolumn{2}{|c|}{ "Quadro 1} & \multicolumn{8}{|c|}{ EXPANSÃO DA USP } \\
\hline Ano & Novos Campi & Opções & Vagas & Inscritos & Área constr. & Orçamento & Alunos (grad.+pós) & Docentes & Funcionários \\
\hline 2014 & & 177 & 11157 & 172045 & Indisponível & 4595,78 (previsto) & Indisponível & Indisponível & Indisponível \\
\hline 2013 & & 173 & 11082 & 159609 & 1915 & $4410,96(4305,56)$ & $58204+29547$ & 6008 & 17450 \\
\hline 2012 & & 172 & 10952 & 146892 & 1821 & $4299,61(3977,11)$ & $58303+28498$ & 5860 & 16839 \\
\hline 2011 & & 166 & 10752 & 132993 & 1778 & $4194,14(3598,44)$ & $57902+27795$ & 5940 & 16512 \\
\hline 2010 & & 171 & 10702 & 126825 & 1757 & $3649,91(2979,62)$ & $57300+26568$ & 5865 & 16187 \\
\hline 2009 & & 167 & 10607 & 138242 & 1739 & $3840,01(2815,99)$ & $56998+25591$ & 5732 & 15341 \\
\hline 2008 & & 161 & 10452 & 140999 & 1722 & $3431,18(2560,01)$ & $55863+25495$ & 5638 & 15438 \\
\hline 2007 & Leste, Lorena & 153 & 10202 & 142656 & 1637 & $3486,82(2369,21)$ & $54361+25443$ & 5434 & 15221 \\
\hline 2006 & & 149 & 9967 & 170474 & 1611 & $3347,64(2111,11)$ & $51980+24836$ & 5358 & 15409 \\
\hline 2005 & São Carlos 2 & 142 & 9567 & 154513 & 1601 & $3234,89(1964,42)$ & $48530+25007$ & 5222 & 15295 \\
\hline 2004 & & 125 & 8587 & 157808 & 1561 & $2945,96(1767,74)$ & $45946+24408$ & 5078 & 15008 \\
\hline 2003 & & 122 & 8331 & 161147 & 1451 & $2867,34(1530,48)$ & $44696+24312$ & 4953 & 14905 \\
\hline 2002 & & 111 & 7805 & 146307 & 1436 & $2860,26(1404,62)$ & $42554+23709$ & 4884 & 14952 \\
\hline 2001 & & 97 & 7354 & 139746 & 1424 & $3249,10(1273,36)$ & $40162+23765$ & 4755 & 14589 \\
\hline 2000 & & 94 & 7395 & 144732 & 1380 & $3306,14(1173,95)$ & $39326+22774$ & 4694 & 14184 \\
\hline 1999 & & 95 & 7076 & 123685 & 1367 & $2842,73(918,04)$ & $39155+22570$ & 4728 & 14186 \\
\hline 1998 & & 124 & 6921 & 126184 & 1367 & $3188,32(842,25)$ & $33934+21009$ & 4705 & 14659 \\
\hline 1997 & & 123 & 6877 & 116903 & 1316 & $3619,25(887,41)$ & $33020+19713$ & 4852 & 14699 \\
\hline Fontes & 1 & 2 & 3 & 4 & 5 & (26 & 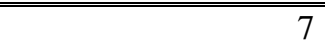 & 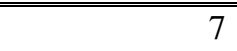 & \\
\hline 1 & \multicolumn{9}{|c|}{ Dados retirados dos sítios de internet das unidades acadêmicas. } \\
\hline 2 & \multicolumn{9}{|c|}{ Opções de cursos (não é igual ao total de cursos oferecidos). Dados FUVEST (nota: até 1998 o vestibular de letras era separado para cada habilitação). } \\
\hline 3,4 & \multicolumn{9}{|c|}{ Dados FUVEST (para evitar distorções, foram excluídos os inscritos nas instituições federais, mas foram mantidos os candidatos a treineiros e Acadepol). } \\
\hline 5 & \multicolumn{9}{|c|}{ Dados do Anuário Estatístico (em milhares de $\mathrm{m}^{2}$ ). } \\
\hline 6 & \multicolumn{9}{|c|}{ Dados da Coordenadoria de Administração Geral (CODAGE), corrigidos segundo o índice IGP-M, em milhões de reais (entre parênteses o valor absoluto). } \\
\hline 7 & \multicolumn{9}{|c|}{ Dados do Anuário Estatístico (nota: em 1989 haviam 5626 docentes, 17735 funcionários não docentes, 31.897 alunos da graduação e 12914 alunos da pós). } \\
\hline & \multicolumn{9}{|c|}{ Quadro: autoria própria. } \\
\hline
\end{tabular}


Esses mesmos dados permitem avaliarmos como a segunda crise se impõe no Brasil. Mais uma vez, como exemplo, observa-se que a universidade pública paulista de fato apresentou um crescimento numérico, mas insuficiente para acompanhar o crescimento da demanda criada pelo modelo de Universidade proposto pela mais recente LDB. A transformação da Universidade em lócus da formação técnica de maior complexidade força a citada universalização, que no Brasil ainda está muito distante de acontecer (em países centrais há índices acima de 90\%, a Argentina está acima de $60 \%$ e o Brasil está em $25,5 \%$ ) ${ }^{280}$, em 2008. Mas, além de insuficiente, é fácil observar que o crescimento de matrículas se realizou sem a contraparte em espaço físico, infraestrutura e pessoal. Causa, portanto, certa degradação física e institucional. As verbas orçamentárias não acompanham o crescimento populacional e são distribuídas ou de acordo com indicadores de produção, ou de acordo com os interesses das agências financiadoras de pesquisas, que se vinculam ao Governo do Estado por meio de outra Secretaria. Nesse caso, as áreas consideradas "operacionais" recebem maior investimento, em detrimento das áreas de pesquisa básica ou geral (como as humanidades). A pesquisa "operacional”, ligada a aplicação produtiva empresarial, é flagrantemente privilegiada ${ }^{281}$. Há, no entanto, uma luta contra esse perfil operacional da pesquisa e da formação técnica, que a coloca a serviço da produção capitalista. Considerando os dados recentes, a crise de legitimidade está posta: essa luta aparentemente está sendo perdida ${ }^{282}$.

Finalmente, com relação à terceira crise, a contradição entre a autonomia universitária e a pressão da sociedade é notável, por exemplo, observando-se a reação da mídia aos conflitos internos à Universidade. Na greve de 2014 havia uma campanha praticamente aberta do jornal "Folha de São Paulo" para que a Universidade de São Paulo adotasse estratégias empresariais e passe a efetuar a cobrança de mensalidades para os alunos que tenham condições de pagá-la ${ }^{283}$. Há,

\footnotetext{
280 INEP (2008).

281 BISCALCHIN (2008).

282 Em 2007, 2010, 2013 e 2014 aconteceram greves nas universidades estaduais. Em todas a questão da privatização esteve em pauta, em alguns casos de forma muito explícita, cogitando-se, inclusive, a possibilidade de cobrança de mensalidades. Sobre a greve de 2014, ver SOUTO MAIOR (2014), sobre a crise de 2013, ver SAFATLE (2013); sobre a greve de 2010, ver FREITAS (2010) e, finalmente, sobre a greve e a ocupação de 2007, ver o texto com as reivindicações dos estudantes, entre as quais destacamos a primeira, que foi repetidamente posta em pauta nas greves subsequentes.

${ }^{283}$ FRAGA e TAKAHASHI (2014) escrevem uma matéria na Folha de São Paulo que calcula valores possíveis para as mensalidades.
} 
portanto, uma pressão para resultados quantitativos da Universidade, mensuráveis via número de vagas no vestibular, ou por índices internacionais de qualidade - que também utilizam critérios quantitativos. E a administração da universidade persegue esses índices ${ }^{284}$.

Com relação à crise institucional, os primeiros aspectos a relevar são sobre a autonomia universitária e a independência financeira. Por um lado, essas condições permitem que a decisão sobre onde aplicar o orçamento seja prerrogativa da reitoria, que submete a proposta orçamentária para o Conselho Universitário. Esse procedimento permite que a própria Universidade decida quais áreas do conhecimento vão receber maiores investimentos, por exemplo. Por outro lado, são condições que permitem que o Governo Estadual se exima da responsabilidade de aplicar outras verbas na Universidade, que não os repasses do Tesouro Estadual devidamente votados pela Assembleia Legislativa de São Paulo. Essa isenção do Governo Estadual deveria impedi-lo de interferir politicamente na universidade, mas não há impedimento para pressioná-la a atender sua administração.

É mais fácil entender como o Governo Estadual interfere na universidade, mesmo sem aplicar verbas adicionais, analisando o processo de escolha do Reitor. Na USP o cargo máximo é escolhido pelo próprio Governador, a partir de uma lista tríplice que é composta pelos três professores titulares (nível hierárquico máximo na carreira) mais votados em eleição com colégio eleitoral muito reduzido (na última eleição o colégio ampliou-se de aproximadamente 300 votantes para 2000). Até a penúltima eleição não havia a formalização de candidaturas. Uma política exercida por poucos indivíduos, sujeita a os problemas típicos das democracias fracas.

Essas condições conduzem, também, a uma centralização decisória, exercida por alguns reitores de forma até autoritária. Para exemplificar, a greve de 2014 foi resultado direto dessa centralização de poder. A última gestão da reitoria, que, como afirmado anteriormente, investiu na recuperação dos quadros funcionais e um alto valor em obras, se caracterizou pela pouca transparência e por, supostamente, não submeter suas decisões ao Conselho Universitário ${ }^{285}$. Essa situação levou a

\footnotetext{
${ }^{284}$ A reitora que comandava a USP durante a greve de 2007, professora Suely Vilela, constrói sua proposta de ampliação da universidade a partir de rankings VILELA, (2007).

$285 \mathrm{O}$ atual reitor, prof. Marco Antonio Zago, o afirma em entrevista para o jornal O Estado de São Paulo, em 01 de junho de 2014. GREENHALG (2014).
} 
Universidade ao comprometimento com a folha salarial em uma porcentagem acima dos repasses do Tesouro Estadual ${ }^{286}$.

A situação financeira precária induz a busca por outras fontes de financiamento para a Universidade pública, que não sejam os repasses diretos do Estado. A decisão institucional ${ }^{287}$ em realizar essa busca pode comprometer a liberdade de pesquisa, em primeiro lugar, mas também o ensino. É fácil constatar nas unidades que já detêm maior quantidade de pesquisas operacionais, pela própria natureza da área, que as empresas privadas já financiam o pagamento de pesquisadores estagiários, ou mesmo realizam parcerias nas quais a empresa paga despesas com a pesquisa enquanto a instituição usa seu know-how e seu pessoal ${ }^{288}$. Por exemplo, as empresas transferem a prática de pesquisa e desenvolvimento de suas dependências para as dependências da Universidade, depois recebendo os royalties compartilhados sobre as patentes. Ganham, com isso, a riqueza do ambiente universitário, livram-se da imobilização do patrimônio, despesas trabalhistas, etc. Outro exemplo é a submissão de todas as pesquisas individuais dos ingressantes em programas de pós-graduação necessariamente se vincularem a uma pesquisa maior com visível interesse mercadológico (e em casos mais extremos até vinculados a uma empresa específica). Um exemplo real que foi divulgado com grande regozijo por ambas as partes foi a assinatura de um convênio formal entre a Microsoft e a Universidade de São Paulo, para a criação de um chamado Centro de Estudos de Tecnologia e Sociedade, com a aplicação de 720 mil dólares por parte da empresa ${ }^{289}$. A despeito da notícia publicada prever "total independência", já que seria coordenada pela USP, não há qualquer garantia que seus "produtos" efetivamente sejam utilizados pela empresa, ou que os formandos não sejam treinados com o objetivo específico de posteriormente serem contratados pela empresa. Outro exemplo das transferências são as spin-offs acadêmicas, empresas criadas pela transferência de conhecimento e tecnologia gerados na universidade ${ }^{290}$. Há também o caso do Parque Tecnológico de Ribeirão

\footnotetext{
286 VREA (2014)

${ }^{287}$ A Comissão de Planejamento composta na comemoração de 75 anos da USP realizou um trabalho com o objetivo de refletir sobre os próximos 25 anos da instituição, nos quais foram traçadas metas, entre as quais diversificar as fontes de financiamento da Universidade. MARQUES (2008).

288 BIANCHI (2008).

289 SALA DE IMPRENSA (2013) e MICROSOFT (2013).

290 TERRA (2001).
} 
Quadro 2: verbas destinadas a obras em execução 2014.

\begin{tabular}{|c|c|}
\hline Unidade & Valor \\
\hline$\overline{\mathrm{FOB}}$ & $\mathrm{R} \$ 6.234 .027,00$ \\
\hline$\overline{\text { FMRP }}$ & $\mathrm{R} \$ 2.143 .839,00$ \\
\hline EEFERP & $\mathrm{R} \$ 364.856,00$ \\
\hline$\overline{\text { FCFRP }}$ & $\mathrm{R} \$ 941.558,00$ \\
\hline$\overline{\text { FORP }}$ & $R \$ 95.807,00$ \\
\hline$\overline{\mathrm{FCF}}$ & $\mathrm{R} \$ 6.032 .228,00$ \\
\hline$\overline{\text { FM }}$ & $\mathrm{R} \$ 12.760 .708,00$ \\
\hline$\overline{\text { FSP }}$ & $\mathrm{R} \$ 331.052,00$ \\
\hline$\overline{\mathrm{IB}}$ & $\mathrm{R} \$ 4.488 .403,00$ \\
\hline $\begin{array}{l}\text { EEFE } \\
\end{array}$ & $\mathrm{R} \$ 1.892 .594,00$ \\
\hline$\overline{\mathrm{FO}}$ & $\mathrm{R} \$ 656.808,00$ \\
\hline$\overline{I C B}$ & $\mathrm{R} \$ 1.585 .614,00$ \\
\hline$\overline{\text { ESALQ }}$ & $\mathrm{R} \$ 10.265 .643,00$ \\
\hline$\overline{\text { FZEA }}$ & $\mathrm{R} \$ 5.790 .276,00$ \\
\hline$\overline{\text { FMVZ }}$ & $\mathrm{R} \$ 7.798 .418,00$ \\
\hline$\overline{\mathrm{EEL}}$ & $\mathrm{R} \$ 6.294 .556,00$ \\
\hline$\overline{P q}$ Tecn RP & $\mathrm{R} \$ 14.560 .503,00$ \\
\hline$\overline{\mathrm{EESC}}$ & $\mathrm{R} \$ 2.849 .200,00$ \\
\hline$\overline{I C M C}$ & $\mathrm{R} \$ 111.000,00$ \\
\hline IFSC & $\mathrm{R} \$ 3.767 .900,00$ \\
\hline$\overline{\text { Poli }}$ & $\mathrm{R} \$ 6.621 .232,00$ \\
\hline $\mathrm{IME}$ & $\mathrm{R} \$ 869.570,00$ \\
\hline$\overline{\mathrm{IQ}}$ & $\mathrm{R} \$ 608.132,00$ \\
\hline 10 & $\mathrm{R} \$ 1.756 .272,00$ \\
\hline$\overline{\text { FFCLRP }}$ & $\mathrm{R} \$ 1.049 .834,00$ \\
\hline $\begin{array}{l}\text { FEARP } \\
\end{array}$ & $\mathrm{R} \$ 2.660 .880,00$ \\
\hline$\overline{\mathrm{EACH}}$ & $\mathrm{R} \$ 1.755 .000,00$ \\
\hline$\overline{F D}$ & $\mathrm{R} \$ 2.073 .668,00$ \\
\hline$\overline{\mathrm{FE}}$ & $\mathrm{R} \$ 1.314 .876,00$ \\
\hline$\overline{\mathrm{FFLCH}}$ & $\mathrm{R} \$ 326.829,00$ \\
\hline$\overline{\mathrm{ECA}}$ & $R \$ 0,00$ \\
\hline$\overline{\mathrm{EE}}$ & $\mathrm{R} \$ 0,00$ \\
\hline EERP & $R \$ 0,00$ \\
\hline IAG & $R \$ 0,00$ \\
\hline IAU & $R \$ 0,00$ \\
\hline IF & $R \$ 0,00$ \\
\hline IGc & $R \$ 0,00$ \\
\hline IMT & $R \$ 0,00$ \\
\hline$\overline{\text { FAU }}$ & $\mathrm{R} \$ 0,00$ \\
\hline IEE & $\mathrm{R} \$ 0,00$ \\
\hline$\overline{I P}$ & $\mathrm{R} \$ 0,00$ \\
\hline$\overline{\text { FDRP }}$ & $R \$ 0,00$ \\
\hline IQSC & $R \$ 0,00$ \\
\hline
\end{tabular}

Fonte: SEF (quadro do autor).
Preto (tratado mais adiante nesse texto). É possível denominar essa prática de "privatização por dentro".

Outro aspecto da crise institucional é relativo à "concorrência" com as universidades privadas. Estas conseguem se adequar rapidamente para suprir demandas do "mercado", ou seja, formar rapidamente profissionais qualificados de determinada função, em determinado lugar. Para cumprir essa função de "mercado", algumas instituições públicas se adaptam com a criação de um campus ou unidade com essa função específica, ou, na esfera federal, com a criação de Institutos Tecnológicos. No caso da USP a resposta foi criar um campus novo, na zona leste de São Paulo, e ali instalar uma nova unidade (a Escola de Artes, Ciências e Humanidades - EACH). Nessa unidade foram instaladas mais de mil vagas em cursos de nível tecnológico nas três grandes áreas do conhecimento, com formação em oito semestres e aulas em período parcial (apenas matutino, vespertino ou noturno) ${ }^{291}$. Entretanto, a implantação da chamada USP Leste não é apenas um reflexo da crise institucional, mas, principalmente, é um reflexo da crise de legitimidade. De acordo com essa visão predominante, a pressão da sociedade para a ampliação da Universidade pública só pode ser respondida em grande quantidade e de maneira rápida assumindo-se a mesma estratégia das empresas privadas de ensino superior, simultaneamente precarizando o ensino, desvinculando-o da pesquisa e extensão e formando em menos tempo, com menor carga horária. 
Ainda sobre a crise de legitimidade, as pressões para a ampliação da universidade pública foram respondidas com o aumento do número de cursos e vagas apresentado no Quadro 1. Para responder a esse aumento diversas obras físicas foram e estão sendo realizadas. O Quadro 2 apresenta os valores investidos em obras em execução nos anos de 2013 e 2014, para cada unidade da USP. Alguns contratos não são vinculados a unidades, por esse motivo a somatória não é igual ao total. Individualmente, os maiores receptores foram obras ligadas à reitoria. Os contratos de substituição dos sistemas de iluminação pública (quase cem milhões de reais), destinados aos museus (mais de 124 milhões de reais), construção do Centro de Convenções (quase 105 milhões de reais), edifício para órgãos da reitoria na Rua da Consolação (quase 74 milhões de reais), segunda etapa do centro de difusão internacional (48 milhões de reais), segunda etapa do prédio da reitoria (quase 26 milhões de reais), todos apresentam valores muito superiores aos destinados para alguma unidade de ensino, no período. Algumas dessas obras nada têm a ver com a expansão de cursos e vagas, como o Centro de Convenções, e o centro de difusão internacional. Ao contrário, ambas obras cuja finalidade é mais ligada ao processo de privatização e venda de serviços oferecidos pela Universidade.

Também é notável o investimento realizado pela USP para a construção do Parque Tecnológico de Ribeirão Preto. Além de ceder o terreno no qual foram construídos os edifícios que o compõem, a Universidade investiu boa parte dos mais de 14 milhões de reais para sua construção. O Parque Tecnológico é um espaço que será gerido por uma fundação municipal ${ }^{292}$ daquela cidade e conta com uma incubadora de empresas "de base tecnológica", com a oferta de área para produção e infraestrutura administrativa. Conta, também, com espaço para instalação da área de pesquisa e desenvolvimento de empresas que atuam com tecnologia, e até áreas produtivas para essas empresas.

Entre as unidades de ensino, é notável o pequeno investimento nas unidades de humanidades. Enquanto as unidades de ciências biológicas receberam mais de 37 milhões e as unidades de engenharias e agrárias receberam mais de 45 milhões, as unidades de ciências sociais aplicadas receberam menos de 7 milhões e as unidades de humanidades menos de 2 milhões de reais. As pesquisas operacionais se

292 FIPASE (2014). 
concentram na área de ciências biológicas (desenvolvimento de fármacos e procedimentos na área da saúde humana e animal), engenharias (desenvolvimento de patentes ligadas a produtos tecnológicos) e ciências agrárias (desenvolvimento de insumos e tecnologias ligadas à produtividade e controle da produção).

Viceja, portanto, a crise de contradição entre o papel original da Universidade e o papel assumido atualmente, que surge e se amplia com a submissão da instituição Universidade à racionalidade do capitalismo, com o utilitarismo das instituições e dos saberes. A expansão da Universidade, inclusive a expansão física, está a serviço desse utilitarismo. 


\section{CAPÍTULO 4}

\section{Conclusão: Dificuldades e Perspectivas}

\subsection{Perspectivas: a relação do Campus Fernando Costa e Pirassununga hoje}

De acordo com Bender, as relações entre a universidade e a cidade são necessariamente tensas ${ }^{293}$, principalmente pelas suas diferentes funções: a primeira tem como principal função cultivar a educação enquanto a segunda tem como principal função promover as trocas econômicas (em que pese essa afirmação ser bastante reducionista). No entanto, ambas são categorias heterogêneas: possuem enorme diversidade dentro de seus espaços. Hoje essa separação está bem clara em Pirassununga. O Campus Fernando Costa, a despeito da intensificação de seu uso, do aumento da população que o frequenta e da diversificação de suas funções devido à inauguração de novos cursos, mantém sua característica rural, as paisagens pastoris e uma dinâmica interna que tem traços de urbanidade, mas caráter essencialmente rural. Já a cidade de Pirassununga vem crescendo no sentido do vetor norte, cujo acesso principal (e até 2015 o único) é a Avenida Duque de Caxias Norte que faz a fronteira entre as duas realidades. A zona norte é essencialmente residencial, de recorte sócio econômico popular e médio, com alguns eixos comerciais, como a própria Avenida Duque de Caxias Norte. A partir do quarteirão seguinte ao acesso da Universidade, a avenida possui pistas marginais, que concentram o comércio, e uma pista central, de trânsito rápido (porém dotada de limitadores de velocidade). A área de serviços e comércios mais dinâmica da cidade, o Centro, está do lado oposto, interligado pelos eixos das ruas Siqueira Campos e Duque de Caxias, que fazem parte dessa área mais dinâmica. Há, portanto, uma complementaridade que não se efetiva, que poderia ser melhor explorada por ambas as partes.

Um dado importante é referente ao sistema de planejamento da cidade. O

293 BENDER (1988), página 290. 
Plano Diretor vigente ${ }^{294}$, datado de 2006 e revisado praticamente sem alterações em 2011 (apenas o zoneamento teve modificações), não faz referência aos territórios universitários. Apenas menciona o eixo viário de acesso, a Avenida Duque de Caxias Norte, prevendo melhorias. Com exceção de sua duplicação (detalhada no capítulo anterior), que foi um caso no qual a ação de ambas instituições foi inadequada (Prefeituras do Município e do Campus), percebemos que a cidade, de maneira oficial, pouco lidou com a existência do Campus. Em pesquisa na legislação urbanística anterior, cuja vigência foi superada pelo Plano Diretor de 2006, também estendemos essa conclusão para o período anterior, inclusive anterior a vinculação à USP 295.

Bender ressalta a importância da cidade no projeto pedagógico da universidade 296. Seu foco são cidades grandes e universidades múltiplas, porém com uma abordagem essencialmente utilitarista: qual a função que essas universidades exercem para a vida urbana nessas cidades (Londres e Nova lorque). Refazendo essa analogia, a cidade de Pirassununga tem um histórico econômico ligado ao desenvolvimento agrário, que ainda se faz presente na cadeia econômica da cana de açúcar, principalmente. A história do atual Campus Fernando Costa foi influenciada e influenciou esse quadro. Atualmente as trocas se alteraram um pouco: o foco em animais e alimentos tem feito surgir no município algumas empresas desse ramo (uma fábrica de biscoitos, algumas fábricas de rações para animais, além do resgate dos alambiques de cana, em contraponto às empresas multinacionais do ramo já instaladas). Portanto, do ponto de vista utilitário, a Universidade em Pirassununga também tem essa importância, confirmando a observação de Bender.

Finalmente, um aspecto que entendemos ter significativa importância é relativo à "cultura pública" da universidade, que está ligada ao preparo dos jovens para a vida pública 297. A função contemporânea da universidade, independente de sua operacionalização, cria e é influenciada por uma "cultura pública". Está imersa, portanto, em uma esfera pública, noção que está inextricavelmente associada à experiência de uma vida urbana. Desenvolve-se, portanto, uma participação da

\footnotetext{
${ }^{294}$ Lei Complementar n 69 de 05/11/2006.

295 Consulta à Câmara de Vereadores de Pirassununga.

296 Id., página 7.

297 Ibid., página 294.
} 
comunidade acadêmica na vida política da cidade. Há alguns elementos dessa participação bem visíveis: um Cursinho Popular Pré-vestibular, uma campanha contínua de cuidados com animais de trabalho (cavalos) e a utilização do território como espaço de prática de esportes e passeio. E há outros elementos menos visíveis, como a influência cultural que parte da comunidade acadêmica causa na cidade. Por exemplo, atualmente há pelo menos três docentes da USP entre os quarenta integrantes da Academia Pirassununguense de Letras, Artes e Ciências (APLACE).

\subsubsection{Algumas diretrizes de planejamento para o Campus Fernando Costa da USP}

A pesquisa realizada permite que avaliemos alguns aspectos físicos do Campus Fernando Costa que podem fundamentar ou compor um diagnóstico para seu planejamento.

Em primeiro lugar ressaltamos a questão da preservação do patrimônio histórico e da paisagem: a despeito das grandes transformações ocorridas no projeto original e os impactos das intervenções recentes, há diversos elementos que ainda podem e devem ser mantidos na paisagem. Algumas edificações representativas e alguns elementos do traçado contém valor histórico e cultural e de alguma maneira estão preservados. Portanto, devem ser realizadas ações para a sua manutenção e valorização. O tombamento pode ser uma ação válida, possível, e ajudaria na manutenção desse patrimônio, tanto enquanto reconhecimento desse valor histórico e cultural quando forma de acesso a benefícios como financiamentos e divulgação turística.

Especificamente, devem ser mantidos com o máximo rigor alguns edifícios que ainda mantêm a maior parte das características originais. Dos exemplares que mantêm tanto a fachada quanto os espaços internos originais, citamos: o que restou do antigo portal, o atual Centro de Eventos (antigo Clube de Campo), o atual Centro de Apoio à Pesquisa e Extensão da FMVZ (CAEPE, antigo Hospital Veterinário e Escola Primária), a arquibancada do antigo Parque de Exposições, o antigo ginásio de esportes, a cavalariça (que mantém a função original), o prédio central, e algumas residências. Outros edifícios devem ser parcialmente protegidos, pelo menos a fachada e a implantação. São eles: os edifícios leste e oeste do antigo parque de 
exposições, o Edifício João Soares Veiga, o reservatório de água do prédio central, o edifício sede do VPS / FMVZ, o edifício da guarda universitária e outras residências que já não cumprem a função original.

Tão ou mais importante quanto a manutenção e preservação dos edifícios é a manutenção e preservação de elementos do traçado. O eixo central que conecta as partes e dá sentido à organização dos grandes setores deve ser preservado. Há discussões na comunidade acadêmica sobre sua possível duplicação, que devem ser aprofundadas e questionadas. A área entre as duas portarias, que é o início desse eixo, também poderia ser repensada, recuperando o trecho entre a rotatória e o portal antigo, pelo menos para o acesso preferencial dos pedestres.

A distribuição dos edifícios na região do antigo Parque de Exposições ainda não descaracterizou totalmente esse espaço. É importante manter o prédio da arquibancada e o campo de exposições, como marcos históricos, arquitetônicos e urbanísticos dessa função anterior. Culminando esse complexo, do outro lado do eixo principal, há o atual CAEPE, em frente do qual há um monumento azulejado, elementos que também devem ser mantidos e valorizados.

Já na outra ponta do eixo principal há o prédio central e seu entorno. Na parte frontal há a imensa rotatória em leve aclive, culminando no próprio prédio central. Ao redor e atrás deste, há um sistema viário em rotatórias, com vias de desaceleração. E na parte posterior estão implantados três edifícios de serviços, já bastante descaracterizados, porém arranjados de maneira a compor um complexo bastante coerente. Esse traçado também deve ser mantido e preservado.

Finalmente, há alguns setores chamados de "colônias", que são as antigas colônias residenciais, compostas por edifícios iguais ou muito parecidos, que permanecem arranjadas de maneira parqueada, isoladas em meio aos jardins, distribuídas ao longo das vias curvilíneas. Esse arranjo pode ser observado na Colônia dos Mestres, na Colônia dos Professores, na Colônia da Mata, principalmente. Devem ser mantidas e preservadas, e para abrigar os novos e inevitáveis usos as reformas devem ser bastante criteriosas.

Sobre a questão ambiental, podemos destacar também o histórico de preservação e as ações recentes. De acordo com a Resolução da Reitoria ํㅜ 6634 de 24 de setembro de 2013: 
"Ficam regulamentadas, nos termos das descrições técnicas a seguir indicadas, as áreas já declaradas de caráter de preservação permanente e destinadas apenas à conservação, à restauração, à pesquisa, à extensão e ao ensino, situadas no Campus USP de Pirassununga, denominadas Reservas Ecológicas da USP..."

O total de áreas citadas nesta Resolução soma pouco mais de 800 ha, incluindo as áreas de preservação permanente legais, as matas densas (e até primárias), os cursos d'água e áreas de corredores ecológicos. Mais recentemente, a USP recebeu verbas da circunscrição judiciária de Pirassununga (Tribunal de Justiça e Ministério Público), para a promoção do uso sustentável dessas áreas, intensificando a visitação, com sistema de empréstimo de bicicletas, sinalização e melhoria das estradas rurais.

\subsubsection{Especificidades e generalidades do caso estudado}

Os territórios universitários, no Brasil e mais especificamente em Pirassununga, são expressões de correntes urbanísticas ou culturais e também são resultados de projetos políticos. Esse é um primeiro aspecto que confere identidade ${ }^{298}$ ao território estudado: há uma unidade, que amarra um projeto influenciado por uma corrente urbanística e cultural e um projeto político. Ou seja, uma arquitetura neocolonial e o traçado híbrido, com aspectos pitorescos e eixos beaux arts e um projeto político que visava a formação integral do trabalhador do campo, oferecendo-o uma educação técnica aprimorada e equipamentos para sua integração social e esportiva.

No entanto, ao tornar-se parte da USP, o território assume funções mais utilitárias. Ainda que a formação superior oferecida pela USP inclua os aspectos culturais e sociais, o foco é a formação profissional e técnica ${ }^{299}$. Nesse aspecto observamos que o caso estudado está vinculado às exigências operacionais da universidade contemporânea. Sem dúvida isso influencia o espaço físico, já que exige alterações e flexibilizações nos espaços edificados e na infraestrutura oferecida para essa operacionalização, conforme afirma Muthesius. Em um ambiente rural, essa

\footnotetext{
298 Não pretendemos, neste trabalho, nos aprofundar sobre o conceito de identidade, que na antropologia é assunto bastante extenso. Adotamos, aqui, a premissa que há, na universidade, uma identificação amplamente aceita que costuma receber o nome de "comunidade acadêmica".

299 BENDER (1988), pg. 292.
} 
operacionalização também é perceptível pela ocupação do solo, destinado às culturas comerciais.

Finalizando, há um aspecto complementar: o Campus Fernando Costa tem uma identidade que o destaca (ou complementa) de uma identidade mais geral da USP, assim como a ESALQ em Piracicaba. Em Piracicaba há um elemento ainda incipiente em Pirassununga, que é a intensidade da vida em repúblicas estudantis durante o período em que o estudante reside na cidade. A experiência da vida em repúblicas se confunde com a vida acadêmica, ainda que territorialmente não haja contiguidade ${ }^{300}$. A vida dentro da universidade, para aqueles que residem dentro de seus limites, transforma o território universitário na própria cidade. No caso da USP em Pirassununga a imersão é ainda maior, pela deficiência do transporte público, que praticamente isola os moradores, principalmente nos finais de semana.

A influência do lugar na construção da identidade nos territórios universitários é reforçada com a especificidade desse lugar. Ou seja, lugares com uma arquitetura Figura 91: Em destaque, a área da USP em Pirassununga e a cidade, em 2016.

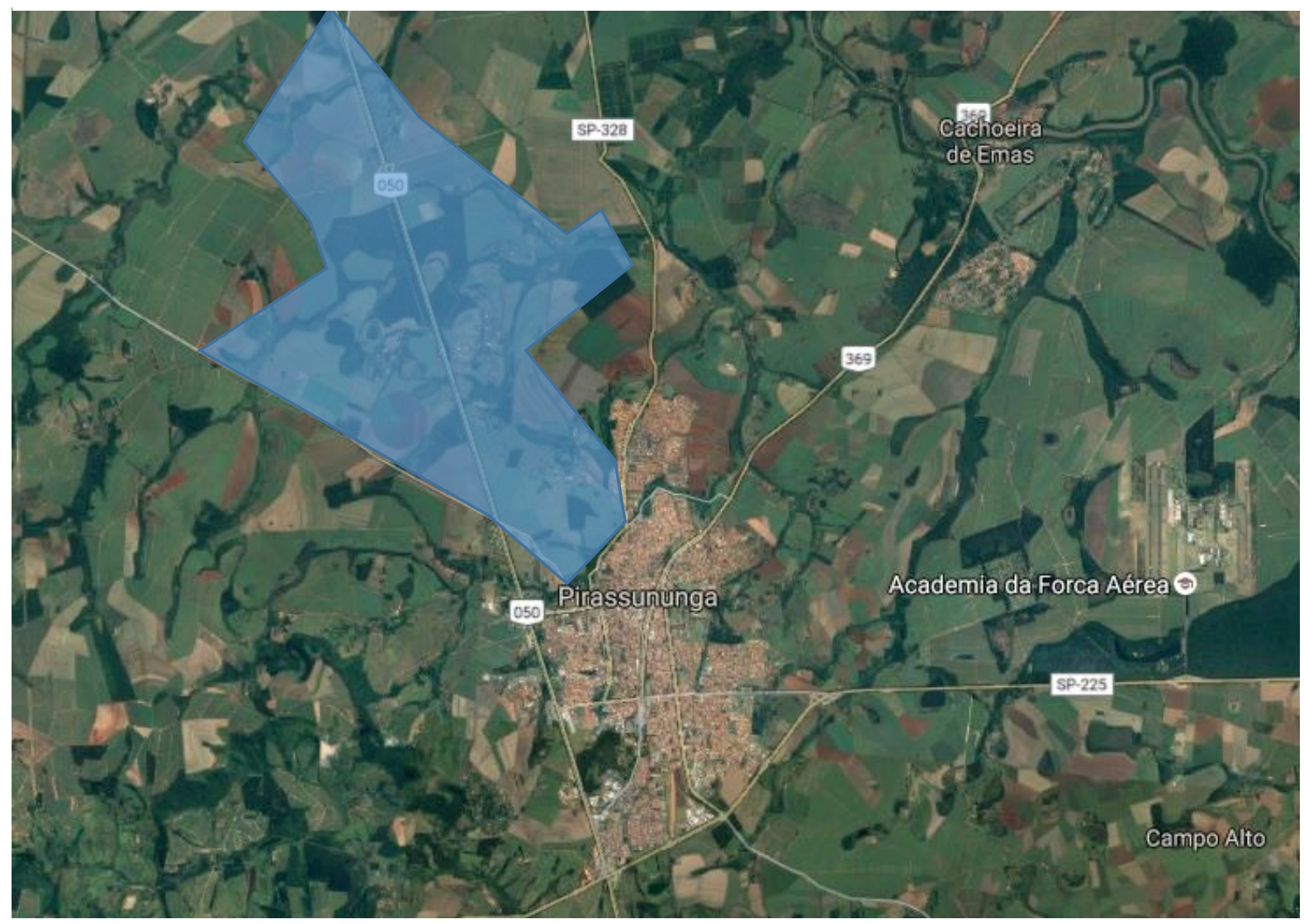

Fonte: Google Earth, com edição.

300 MAGNANI (2004), pg. 82. 
identificável, cuja unidade seja facilmente perceptível, também ajudam na construção da identidade ${ }^{301}$. No Campus Fernando Costa a arquitetura e o arranjo urbanístico possuem essa identificação e percepção, a ponto do logotipo da Prefeitura do Campus e da FZEA estilizarem as fachadas dos prédios que ocupam.

O último aspecto que pretendemos tratar nessa dissertação é relativo a uma possível generalidade na categoria dos territórios universitários. Há algumas tentativas na bibliografia para agrupar os territórios universitários em subcategorias 302. O caso estudado, e os territórios universitários em ambiente rural de maneira geral, não se classificam em nenhuma dessas categorias. Recebem o nome de "campus" pois é esse o termo que institucionalmente as universidades utilizam para referiremse aos seus territórios. De fato, se assemelham aos territórios universitários das instituições norte-americanas do século XIX quanto ao afastamento da cidade, porém possuem área muito maior e função muito mais específica. Mas não se encaixam em subcategorias urbanas, pois não buscam harmonizar-se com a cidade (e nem haveria como harmonizar, por exemplo, um pasto experimental com um bairro residencial) e por suas vastas dimensões que resultam em longos trechos de deslocamento cotidiano.

Invocamos, portanto, uma categoria específica de territórios universitários: aqueles situados em ambiente rural. Além do aspecto funcional, que é bastante diversificado, os aspectos formais de um território universitário em ambiente rural também divergem bastante dos demais, mesmo aqueles que se encontram fora da trama urbana, mas não possuem a inserção no meio rural.

\footnotetext{
301 Idem.

302 MAHLER (2015). A autora, que também utiliza o termo "territórios universitários", classifica a forma dos territórios universitários em "territórios urbanos", "sistemas em trama aberta", "morfologia radioconcêntrica" e "megaestruturas lineares". Os "territórios urbanos" são os que tentam harmonizar-se com a cidade, buscando permeabilidades, mas reivindicando seu território privativo. Os "sistemas em trama aberta" seriam os que buscam maior compacidade, racionalizados, com espaços multifuncionais e integrados e adequado tempo de deslocamento. A "morfologia radio-concêntrica" explora a "importância da configuração do espaço físico na concepção institucional", portanto a forma do território universitário é resultado do arranjo institucional da universidade. E as "megaestruturas lineares" se referem principalmente ao porte e à flexibilidade dos territórios elegidos na categoria.
} 



\section{REFERÊNCIAS BIBLIOGRÁFICAS}

AB'SABER, Aziz. São Paulo: Ensaios Entreveros. São Paulo: EDUSP e Imprensa Oficial, 2004.

ADELYN PEREZ. AD Classics: IIT Master Plan and Buildings / Mies van der Rohe. 16 maio de 2010. ArchDaily. Disponível em: http://www.archdaily.com/59816/ad-classicsiit-master-plan-and-buildings-mies-van-der-rohe/. Acessado em 23 de outubro de 2016.

AGUIRRE SALVADOR, Rodolfo. La Real Universidad de México frente a la crisis de independencia: entre la lealtad monárquica y la decadencia corporativa. In: Cuadernos del Instituto Antonio de Nebrija de Estudios sobre la Universidad, México, vol 14, edición 1.pgs. 11-29. 2011.

AL ASSAL, Mariana R. B. Arquitetura, Identidade Nacional e Projetos Políticos na Ditadura Varguista. Dissertação de Mestrado. FAU-USP. São Paulo, 2009.

- Escola Prática de Agricultura Fernando Costa: Patrimônio Cultural da Universidade de São Paulo. Trabalho Final de Graduação. FAU-USP. São Paulo, 2005 ALBERTO, Klaus Chaves. Três Projetos para uma Universidade do Brasil. Dissertação de Mestrado. FAU-UFRJ. Rio de Janeiro, 2004.

ALBUQUERQUE, Ricardo e GHION, Esleibe (coord.). História do Departamento de Nutrição e Produção Animal. São Paulo, VNP, 2007.

ALEXANDER, Christopher et al. The Oregon Experiment. Oxford: University Press, 1975.

. Uma Linguagem de padrões. Porto Alegre: Bookman, 2012.

ALMEIDA PINTO, Gelson e BUFFA, Esther. Arquitetura e educação: campus universitários brasileiros. São Carlos: EdUFSCar, 2009.

ALTAFIM, Ruy A. C. 50 anos da EESC - Um olhar no passado visando o futuro. 02. ed. São Carlos: Escola de Engenharia de São Carlos, 2004.

ARAÑO, Axel (ed.). Arquitectura escolar, SEP 90 años. México, Secretaría de Educación Pública e Fragonard 70, 2011. 
ATCON, R.P. Manual para o planejamento integral de campus universitário. Brasília, Conselho de Reitores das universidades Brasileiras, 1970.

ATECEL - Associação Técnico Científica Ernesto Luís de Oliveira Júnior. Mapa de Geomorfologia do Estado da Paraíba. Campina Grande, 2002a.

ATECEL - Associação Técnico Científica Ernesto Luís de Oliveira Júnior. Mapa de Classe de Capacidade de Uso de Terras. Campina Grande, 2002b.

BARBIN, Henrique S. Estudo das transformações na conformação dos maciços arbóreos/arbustivos do Parque da Escola Superior de Agricultura 'Luiz de Queiroz' Universidade de São Paulo, através de fotografias aéreas verticais e levantamentos florísticos de épocas distintas. Dissertação de Mestrado. Esalq-USP. Piracicaba, 1999.

BAUER, Carlos. Do Ensino Superior: Aspectos de Sua História no Brasil. In: BAUER, C. A Classe Operária Vai ao Campus. São Paulo: Instituto Sundermann, 2010.

BATTAUS, Danila M. A. Processos Participativos na Arquitetura e Urbanismo de Christopher Alexander. Relatório Técnico de Pós-Doutorado. IAU-USP. São Carlos, 2014.

BENDER, Thomas (org.) The University and the city: from medieval origins to the present. Oxford: University Press, 1988.

BIANCHI, Alvaro. Autonomia Universitária como projeto. In: BIANCHI, A. (org.). Transgressões: As Ocupações de Reitoria e a Crise das Universidades Públicas. São Paulo: Instituto Sundermann, 2008.

BISCALCHIN, Fabio C. Universidade, Mercado e a Formação de Papagaios Burros. Piracicaba, Biscalchin, 2008.

BOSI, Alfredo. A Universidade Pública Brasileira: Perfil e Acesso. In Cadernos Adenauer 6, Universidade: panorama e perspectivas. São Paulo: Fundação Konrad Adenauer, agosto 2000.

BRAVO, Jorge. San Marcos es el Perú: urbanismo y pensamiento en la Ciudad Universitaria de San Marcos. In: Revista Electronica Imágenes del Instituto de Investigaciones Estéticas de la UNAM, México, out 2007. Disponível em: http://www.esteticas.unam.mx/revista_imagenes/anotaciones/ano_bravo05.html. Acessado em 18/04/2015. 
CABRAL, Neyde A. J. A Universidade de São Paulo: Modelos e Projetos. Tese de Doutorado. FAU-USP. São Paulo, 2004.

CABRAL, Renata C.. Mario Russo: um Arquiteto Italiano Racionalista no Recife. Recife: Editora UFPE, 2006.

CAMPÊLO, Marta Campus no Nordeste: Reforma Universitária de 1968. Tese de Doutorado. Dinter FAU-USP e FAU-UFC. São Paulo, 2012.

CAMPOS, Ernesto S. Cidade Universitária da Universidade de São Paulo: Aspectos Gerais do Planejamento e Execução. São Paulo: Comissão da Cidade Universitária de São Paulo. 1954. . História da Universidade de São Paulo. São Paulo: USP, 1954.

CAMPOS, Pedro H. P. A ditadura dos empreiteiros: as empresas nacionais de construção pesada, suas formas associativas e o Estado ditatorial brasileiro (19641985). Tese de doutorado em História. ICHF-UFF. Niterói, 2012.

CAVALCANTI, Lauro. Moderno e Brasileiro: a história de uma nova linguagem na arquitetura (1930-1960). Rio de Janeiro, Jorge Zahar, 2006.

CPC - Centro de Preservação Cultural da USP. Cidades universitárias: Patrimônio Urbanístico e Arquitetônico da USP. São Paulo: EDUSP e Imprensa Oficial, 2005.

CPC - Centro de Preservação Cultural da USP. Patrimônio Construído da USP: Preservação, gestão e memória. São Paulo: EDUSP, 2014.

CEPAGRI - Centro de Pesquisas Meteorológicas e Climáticas Aplicadas à Agricultura. O Clima dos municípios paulistas. Campinas. Disponível em: http://www.cpa.unicamp.br/outras-informacoes/clima-dos-municipios-paulistas.html. Acessado em: 20/09/2016.

CHAPMAN, M. Perry. American Places: In Search of the Twenty-First Century Campus. Westport: Praeger and American Council of Education, 2006.

CHARLE, Christophe e VERGER, Jacques. História das Universidades. São Paulo, Ed. UNESP, 1996.

CHAUÍ, Marilena. USP 94: a terceira fundação. In: Estudos Avançados, São Paulo, vol. 8, num. 22, 1994. Pg.49-68. 
CONESCAL - Centro Regional de Construcciones Escolares para a América Latina Y Caribe. Conjuntos Universitarios em America Latina. México, 1971.

COSTA, Fernando. Idealismo Construtor. São Paulo: Saraiva, 1931.

- Realizações do Pres Getúlio Vargas no Ministério da Agricultura. Rio de Janeiro: D.I.P., 1941.

. Hino à Terra. São Paulo: D.E.I.P., 1943.

. No Governo de São Paulo. São Paulo: Imprensa Oficial de São Paulo, 1944.

COULSON, Jonathan; ROBERTS, Paul e TAYLOR, Isabelle. University Planning and Architecture: The Search for Perfection. Oxon: Routledge, 2011.

CUNHA, Luiz Antonio. Campus Universitário: opção ou destino? In: MORHY, Lauro (org.). Universidade em Questão. Volume 1. Brasília, Editora UnB, 2003.

DEIP - Departamento Estadual de Informação e Propaganda (DEIP). Fernando Costa e sua vida pública. São Paulo: DEIP, 1943.

DIAS SOBRINHO, José e RISTOFF, Dilvo (2000). Universidade Desconstruída: avaliação institucional e resistência. Florianópolis, Insular, 2000.

DOBER, Richard P. Campus Planning. New York: Reinhold, 1963.

. Campus landscape: functions, forms, features. New York: John Wiley \& Sons, 2000.

EESC - Escola de Engenharia de São Carlos. Documentação EESC-CNDU, Grupo Alexander. Relatório. São Carlos, EESC, 1984.

EMBRAPA - Empresa Brasileira de Pesquisa Agropecuária. Mapa Exploratório Reconhecimento de solos do município de Areia-PB. Recife, 1972.

FAPESP - Fundação de Ampara à Pesquisa do Estado de São Paulo. Indicadores de Ciência, Tecnologia e Inovação 2010. Vol. 1. São Paulo: FAPESP, 2011.

FAPESPA - Fundação Amazônia de Amparo à Estudos e Pesquisas do Pará. Anuário Estatístico do Pará 2015. Belém, FAPESPA, 2015.

FARIA, Marcelo O. Privatização da Cidade Universitária "Armando de Salles Oliveira". Dissertação de Mestrado em Geografia Humana. DG-FFLCH-USP. São Paulo, 2001. FAUSTO, Boris. O crime do restaurante chinês. São Paulo: Companhia das Letras, 
2009.

FERNANDES, Florestan. Universidade Brasileira: reforma ou Revolução? São Paulo: Alfa-ômega, 1975.

FERRAZ, Geraldo. Uma Cidade Universitária no Brasil. In: Zodiac, Milão, ed.11, fev. 1963. Pg. 57-77.

FIPASE - Fundação Instituto Pólo Avançado da Saúde. Dados sobre o Parque Tecnológico. Disponível

em: <http://www.fipase.org.br/index.php?option=com_content\&view=article\&id=4\&ltemid= 13>. Acessado em 30 de julho de 2014.

FRAGA, Erica e TAKAHASHI, Fabio. Mensalidade da USP poderia ser paga por $60 \%$ dos alunos. Folha de São Paulo, 02/06/2014. Disponível em: < http://www1.folha.uol.com.br/educacao/2014/06/1463535-mensalidade-na-usppoderia-ser-paga-por-60-dos-alunos.shtml>. Acessado em 30 jul 2014.

FREITAS, Luiz Carlos de. A Destruição dos Quadros Técnicos e Administrativos nas Universidades Paulistas. Publicado em listas de discussão da UNICAMP, disponível em <http://www.dceunicamp.org.br/campanhaunificada/?p=32. 2010>. Acessado em 20 de agosto de 2015.

GAINES, Thomas A.. The Campus as a Work of Art. Westport: Praeger, 1991.

GÓMEZ MENDOZA, J.: La mirada del geógrafo sobre el paisaje: del conocimiento a la gestión, in MADERUELO, Javier: Paisaje y territorio, Madrid, Fundación Beulas, CDAN, Pensar el paisaje 03, Abada Editores, 2008, págs. 11-56.

GRAVAGNUOLO, B. Historia del Urbanismo em Europa. Madri: Akal. 1998. Original de 1991.

GROPIUS, Walter. Bauhaus: Novarquitetura. São Paulo: Perspectiva. 1997. pg. 132. Original de 1968.

IBGE - Instituto Brasileiro de Geografia e Estatística. Mapa de Solos do Brasil. Rio de Janeiro: IBGE, 2001.

INSTITUTO AGRONÔMICO de Campinas. Mapa Pedológico da Região de Piracicaba. Campinas, 1989.

INEP - Instituto Nacional de Estudos e Pesquisas Educacionais Anísio Teixeira. 
Sinopse Estatística do Censo da educação superior: Sinopse Estatística, de 1998 a 2006. Brasília: Inep-MEC, 2008.

. Divulgação do Censo Superior 2013: Tabela. Brasília, 2014. Disponível em: <http://download.inep.gov.br/educacao_superior/censo_superior/documentos/2014/p rincipais_resultados_censo_2013.xls>. Acessado em 21 out. 2014.

IPPLAP - Instituto de Pesquisas e Planejamento de Piracicaba. Piracicaba em Dados. Disponível em: < http://ipplap.com.br/site/piracicaba-em-dados/>. Acessado em $18 / 02 / 2017$.

KENNEY, Daniel R.. Mission and Place: Strengthening Learning and Community through Campus Design. Westport: Praeger and American Council of Education, 2005. LAVAL, C. e DARDOT, P. La nueva razón del mundo. Valencia: Gedisa, 2013.

LEITE, Rogério C. C. As sete pragas da universidade brasileira. São Paulo: Duas Cidades, 1980.

LIMA (2013), URBANISMO EM MINAS GERAIS: IDEARIOS URBANISTICOS APLICADOS AOS PARQUES NACIONAIS POR ANGELO A. MURGEL (1932-1942). Fabio Jose Martins de Lima . URBANA, V.5, n6, mar.2013 - Dossiê: Urbanistas e Urbanismo- CIEC/UNICAMP

LOURENÇO, M. C. (org). Bens imóveis tombados ou em processo de tombamento da USP. São Paulo: EDUSP e Imprensa Oficial. 2002

MAGNANI, José G. C. Cidade Universitária: Patrimônio e Identidade. In CPC - Centro de Preservação Cultural da USP. Cidades universitárias: Patrimônio Urbanístico e Arquitetônico da USP. São Paulo: EDUSP e Imprensa Oficial, 2005.

MAHLER, Cristine R. Território Universitários: tempos, espaços, formas. Tese de Doutorado. FAU-UnB. Brasília, 2015.

MARQUES, M E CAMPOS, R. De escola agrícola a instituto penal: a polêmica criação do IPA de São José do Rio Preto na década de 1950. In: Caderno de Pesquisas Cdhis, Uberlândia, v.24, n.1, jan./jun. 2011, pgs. 143-158.

MARQUES, Fabrício. A USP do futuro. In: Pesquisa Fapesp, São Paulo, n 152, out. 2008, pag. 36-37.

MARTINS, Zoraide. Agricultura Paulista: Uma história maior que cem anos. São Paulo: 
SAA, 1991.

MARTINS, Ana Luiza. A "São Francisco" na dinâmica da história e da memória da cidade. In CPC - Centro de Preservação Cultural da USP. Cidades universitárias: Patrimônio Urbanístico e Arquitetônico da USP. São Paulo: EDUSP e Imprensa Oficial, 2005.

MASCARO, L. P. Difusão da Arquitetura Neocolonial no Interior Paulista (1920-1950). Tese de Doutorado. São Carlos, EESC-USP, 2008.

. Escolas Práticas de Agricultura: Arquitetura Neocolonial no Interior Paulista. In Anais do $2^{\circ}$ Seminário de Patrimônio Agroindustrial: Lugares de Memória. 19 a 22 de outubro de 2010, EESC- USP, São Carlos.

MATOS, Odilon Nogueira de. A cidade de São Paulo no século XIX. In: Revista de História. São Paulo. Vol. 10. Ed. 21-22 (1955): 89-125.

Mc CLELLAND, Charles. "To Live for Science": Ideals and Realities at the University of Berlin. In BENDER, T. The University and the city: from medieval origins to the present. Oxford: University Press, 1988. Pg. 181-197.

MENDES, Josué C. Universidade de São Paulo: Súmula de sua História. São Paulo: Secretaria de Cultura, Ciência e Tecnologia e Academia de Ciências, 1977.

MENEZES, Luís Carlos. Universidade sitiada: $A$ ameaça de liquidação da universidade brasileira. São Paulo: Ed. Fund. Perseu Abramo, 2000.

MENUCCI, Sud. Prefácio. In COSTA, Fernando. No Governo de São Paulo. São Paulo: Imprensa Oficial de São Paulo, 1944.

MMA - Ministério do Meio Ambiente. Mapa dos Biomas Brasileiros. Brasília: MMA, 2006.

MAA - Ministério da Agricultura e Abastecimento. Mapa de Solos do Rio de Janeiro. Brasília, 2000.

MICROSOFT. Pesquisa de tecnologia e sociedade com a USP. 12/2013. Disponível em: $\quad$ <http://www.microsoft.com/pt-br/about/impacto-no-brasil/educacao-ecapacitacao/iniciativas/pesquisa-de-tecnologia-e-sociedade-com-a-usp.aspx>. Acessado em 30/07/2014. 
MOLINA, Jaime Garcia. El Campus de la Universidad de Concepción: su Desarrollo Urbanistico y Arquitectonico. Concepción: Ediciones Universidad de Concepción, 1994.

. Brunner y el Barrio Universitario de Concepción. In PAZDERKA, Constantino (ed.). Karl Brunner em Chile: Urbanismo Revisitado. Santiago: FAU Universidad de Chile, 2015. Pg. 104-109.

MOTOYAMA, Shozo (org.). USP 70 anos: Imagens de uma história vivida. São Paulo: EDUSP, 2006.

MUTHESIUS, Stephan. The postwar university: utopianist campus and colleges. New Haven; London: Yale university Press, 2000.

PAULA, Christiane e WELTMAN, Fernando L. (orgs). Dicionário Histórico Biográfico Brasileiro pós 1930. $3^{\text {a }}$ ed. Rio de Janeiro: Ed. FGV, 2004

PERECIN, Marly T. G. Os Passos do Saber: a Escola Agrícola Prática Luiz de Queiroz. São Paulo: EDUSP, 2004.

PEREIRA, Fúlvio Teixeira de Barros. Campus Universitário: a formação de seu ideário no Brasil. Memorial de Qualificação de Doutorado. São Carlos, IAU-USP, 2015.

PREFEITURA DO MUNICÍPIO DE PIRASSUNUNGA. O Idealista Realizador. Média metragem documentário, $1994 . \quad$ Disponível em: <https://pirassunungareceptivo.com.br/fernando-costa-o-idealista-realizador/>. Acessado em 30/10/2016.

RANNEY, Victoria (org.). The Papers of Frederick Law Olmsted. Volume V: The California Frontier, 1863-65. Baltimore: John Hopkins University Press, 1990

REIS FILHO, Nestor Goulart. O Caminho do Anhanguera. São Paulo: Via das artes, 2014. v. 1. 144 p.

RIBEIRO, Darcy. A Universidade Necessária. Rio de Janeiro: Paz e Terra, 1968.

RIBEIRO, Renato J. A Universidade e a vida atual: Fellini não via filmes. São Paulo: EDUSP, 2014.

RITTER, Marcelino. A Reconstrução de São Paulo no Governo Fernando Costa. São Paulo, 1943. 
RODRIGUES, Luiz Augusto F. Universidade e a fantasia moderna: a falácia de um modelo espacial único. Niterói: EdUFF, 2001.

RODRIGUES, M. R. V. e ILIANO, R. T. História da FMRP. Disponível em: <http://www.fmrp.usp.br/a-faculdade/historia/>. Acessado em 10/01/2017.

RODRIGUEZ, Janete L. (coord). Atlas Escolar da Paraíba. João Pessoa: Grafset, 2002.

ROSS, Jurandyr e MOROZ, Isabel. Mapa Geomorfológico do Estado de São Paulo. In: Revista do Departamento de Geografia, vol. 10, 1996. Pgs. 01 a 18.

RUMBELAPAGER, Maria de Lourdes. Arquitetura Neocolonial. Seropédica: Editora Universidade Rural, 2005.

SÁ, Paulo. A orientação dos edifícios da Cidade Universitária do Rio de Janeiro. Rio de Janeiro: Instituto Nacional de Technologia, 1937.

SAFATLE, Vladimir. Democracia na USP. Folha de São Paulo, São Paulo, 08/10/2013.

em:

<http://www1.folha.uol.com.br/colunas/vladimirsafatle/2013/10/1353197-democraciana-usp.shtml> Acessado em 20/10/2016.

SALA DE IMPRENSA. Press-release: USP e Microsoft firmam convênio para criação de Centro de Estudos de Tecnologia, 11/12/2013. Disponível em: < http://www.usp.br/imprensa/?p=35462>. Acessado em 30/07/2014.

SANTOS, Boaventura de Souza. Da ideia de universidade à universidade de ideias. Revista Crítica de Ciências Sociais, Coimbra, n. 27/28, p. 11-62, jun. 1989.

- A universidade do século XXI: para uma reforma democrática e emancipatória da universidade. São Paulo: Cortez, 2010. Original de 2004.

SANTOS, Milton. Território, Globalização e Fragmentação. São Paulo: Hucitec, 1994.

SAAESP - Secretaria de Agricultura e Abastecimento do Estado de São Paulo. Relatório da Agricultura 1943. São Paulo, SAAESP, 1944.

. Relatório da Agricultura 1944. São Paulo, SAAESP, 1945.

. Relatório da Agricultura 1945. São Paulo, SAAESP, 1946.

. Relatório da Agricultura 1946. São Paulo, SAAESP, 1947. 
SIMONSEN, Roberto. Elos da Indústria: Quatro discursos pronunciados em junho de 1944. São Paulo: FIESP, 1944

SOUTO MAIOR, Jorge Luiz. Democratização vs. privatização da USP: a cartada final. Blog da Boitempo, disponível em: <http://blogdaboitempo.com.br/2014/05/28/democratizacao-vs-privatizacao-da-usp-acartada-final/>. Acessado em 30 de julho de 2014.

SOUSA, Djalma (S/D). Agência de Informação EMBRAPA, Gleissolo Háplico / Glei Pouco Húmico. Disponível em: <http://www.agencia.cnptia.embrapa.br/Agencia16/AG01/arvore/AG01_95_10112005 101956.html>. Acessado em 30/01/2017.

TELES, T.C. e IOKOI, Z.M.G. Campus Pirassununga da USP: Memória e História. São Paulo: EDUSP. 2005.

TERRA, B. A transferência de tecnologia em universidades empreendedoras: um caminho para inovação tecnológica. Rio Janeiro: Qualitymark, 2001.

TUAN, Yi Fu. Espaço e Lugar: a perspectiva da experiência. São Paulo: Difel, 1983.

TURNER. P. V. Campus: an american planning tradition. Cambridge: MIT Press, 1987. USP - Universidade de São Paulo. Anuário Estatístico de 2001. São Paulo, CodageUSP, 2002.

Anuário Estatístico de 2015. Disponível em: <https://uspdigital.usp.br/anuario/AnuarioControle>. Acessado em 20/02/2017.

VILELA, S. USP: Uma Universidade de Classe Mundial in USP REITORIA, USP 2034: Planejando o Futuro. São Paulo: EDUSP, 2007

VREA - Vice Reitoria Administrativa, atual Coordenadoria de Administração Geral da USP. Informações financeiras para o Conselho Universitário. Disponível em: <http://www.vrea.usp.br/?q=node/5>. Acessado em 30 jul. 2014.

- Dados de orçamentos e despesas da USP. Disponível em: <http://www.vrea.usp.br/files/CO_2014/execucao_abr14.pdf>. Acessado em 30 de julho de 2014.

XAVIER, Marco Antonio. O Campus e a Cidade. In CPC - Centro de Preservação Cultural da USP. Cidades universitárias: Patrimônio Urbanístico e Arquitetônico da 
USP. São Paulo: EDUSP e Imprensa Oficial, 2005.

WANDERLEY, Luiz Eduardo. O que é universidade. São Paulo, Brasiliense, 1988.

Todos os artigos da revista Acrópole estão disponíveis em: < http://www.acropole.fau.usp.br/>. Acessados em 18/02/2017. A seguir os artigos referenciados no texto:

ACRÓPOLE. São Paulo. Jan 1944, pg.288-289, Escola Prática de Agricultura Getúlio Vargas.

ACRÓPOLE. São Paulo. Maio 1944, pg 6-9. Realizações da Divisão de Engenharia Rural da Secretaria de Agricultura de São Paulo.

ACRÓPOLE. São Paulo. Julho 1944, pgs. 90 e 91 Escolas Práticas de Agricultura. ACRÓPOLE. São Paulo. Dez 1944, pg. 245. Escola Prática de Agricultura Fernando Costa.

ACRÓPOLE. São Paulo. Maio 1945, pg. 1. Escola Prática de Agricultura Dr. Paulo de Lima Côrrea.

ACRÓPOLE. São Paulo. Jul 1945, pg.64.

ACRÓPOLE. São Paulo. Ago 1946, pg. 109-111, Escola Prática de Agricultura Gustavo Capanema.

Os sites a seguir são mantidos pelas próprias instituições de ensino. Foram extraídas informações pontuais sobre as instituições citadas ao longo desta dissertação. Acessados entre 03/2015 e 12/2016.

http://www.ufpr.br/portalufpr/historico-2/

http://www.unmsm.edu.pe/home/inicio/historia http://www.unam.mx/acercaunam/es/unam_tiempo/unam/antecedentes.html http://www.unc.edu.ar/institucional/historia/origenes http://www.usfx.info/edif/index.php?id=0\&pag=163\&ex=yes http://ecuadoruniversitario.com/opinion/documentos/breve-resena-historica-de-launiversidad-central-que-hoy-cumple-186-anos/

http://www.usac.edu.gt/historiaUSAC.php. 
http://www.unsaac.edu.pe/universidad/resenia.php

http://www.ucv.ve/sobre-la-ucv/resena-historica.html

http://www.udg.mx/es/historia

http://www.uba.ar/historia/contenidos.php?id=2\&s=19

http://www.umsa.bo/documents/10204/16823/HistoriaUMSA.pdf/516046c6-92de4764-a98c-e252139989e6

http://www.uchile.cl/portal/presentacion/historia/resena-historica/4727/una-mirada-ala-historia

http://www.universidad.edu.uy/renderPage/index/pageld/98\#heading_761

http://unal.edu.co/la-universidad/historia/

http://www.una.py/images/stories/Universidad/Rese\%C3\%B1aHistorica/CRONOLOG IA_UNA_03.06.2014.pdf

http://www.ufam.edu.br/index.php/historia-da-ugm

http://www.eerp.usp.br/corporate-a-eerp/

http://www.forp.usp.br/?page_id=455

http://www.ffclrp.usp.br/affclrp/historico.php

www.fzea.usp.br

http://www.agronomia.ufba.br/historico.html

http://wp.ufpel.edu.br/faem/historico/

http://www.labjor.unicamp.br/midiaciencia/article.php3?id_article=390

http://r1.ufrrj.br/centrodememoria/ufrrj_historia.php

http://www.ufv.br/

http://www.cca.ufpb.br/

https://ccaufpb.wordpress.com/conheca-o-cca/historia-do-cca/

http://www.esalq.usp.br/noticia/detalhe.php?id=716

Site com a lista de reivindicações dos estudantes da ocupação da USP de 2007.

http://arquivoocupa.blogspot.com.br/search/label/As\%2018\%20reivindica\%C3\%A7\%C3\%B5

es\%20dos\%20estudantes\%20da\%20Ocupa\%C3\%A7\%C3\%A30\%20da\%20USP 
ANEXOS 